\title{
Hanford Land Disposal Restrictions Plan for Mixed Wastes
}

Date Published

October 1990
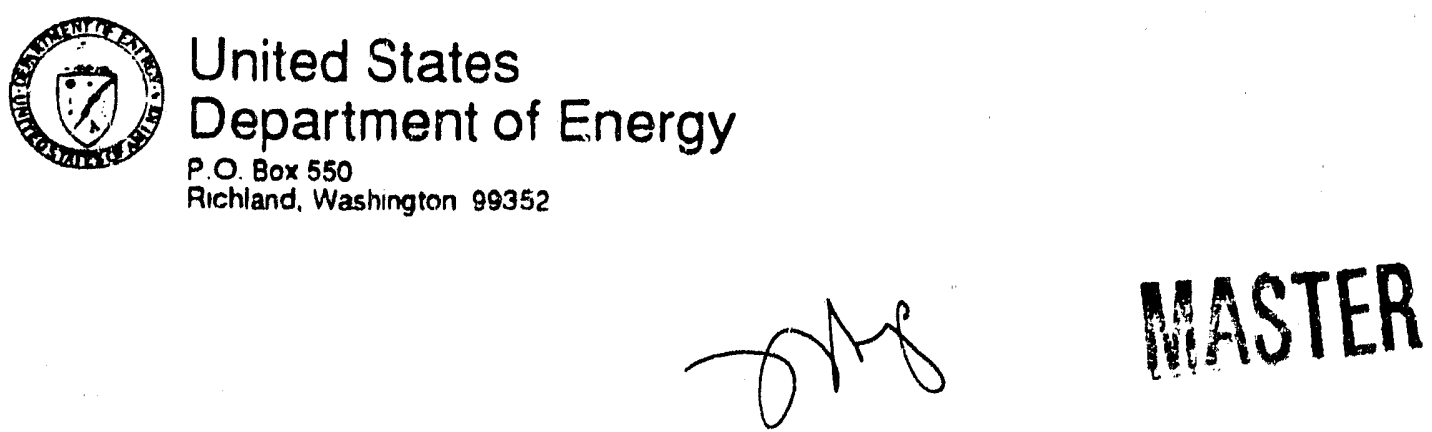

DISTRIBUTION OF THIS DOCUMENT IS URJLIMITED

Approved for Public Release 
1.0 EXECUTIVE SUMMARY . . . . . . . . . . 1-1

2.0 INTRODUCTION $\dot{0} \dot{0}$. . . . . . $2-1$

2.1 BACKGROUND AND PURPOSE . . . . . . . . . . . . . . . . . . . . .

2.2 ASSUMPTIONS

2.3 SCHEDULE AND MECHANICS OF PLAN UPDATE . . . . . . . . . . . . $\quad 2-4$

2.4 MILESTONE PLANNING PROCESS ................. . . . . $2-5$

3.0 SITE SUMMARY

3.1 WASTE GENERATION .................. . . . . . . . . $3-1$

3.2 WASTE CHARACTERIZATION . . . . . . . . . . . . . . . $3-1$

3.3 WASTE STORAGE .................... . . . . . $3-3$

3.4 WASTE TREATMENT ........................ . . . . . . . . $3-4$

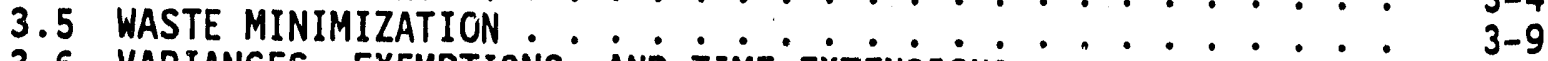

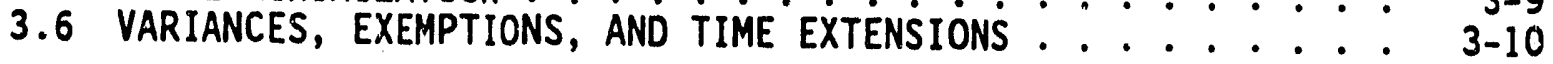

4.0 INDIVIOUAL WASTESTREAM INFORMATION . . . . . . . . . . . . 4-1

4.1 DOUBLE-SHELL TANK WASTE .................. . . . . . . $4-1$

4.2 PUREX AGING WASTE $. . . . . . . . . . . . . . . . . . .44-8$

4.3 SINGLE-SHELL TANK WASTE ............... 4-12

4.4 242-A EVAPORATOR .................... . . . . . . . . . . .

4.54843 SODIUM STORAGE FACILITY WASTE . . . . . . . . . . . . . . $4-22$

4.6 PUREX AMMONIA SCRUBBER WASTE ................... . . . $4-26$

4.7 PUREX PROCESS CONDENSATE . . . . . . . . . . . . . . . . . . . . . . . . $4-31$

4.8 HEXONE WASTE

4.9 183-H SOLAR BASIN WASTE . . . . . . . . . . . . . . . . . . . . . $4-37$

4.10 PUREX TUNNEL 2 WASTE (Mercury) ............... $4-43$

4.11 PUREX TUNNELS 1 AND 2 WASTE (LEAD AND SILVER) . . . . . . . 4-46

4.12 PUREX CANYON WASTE PILE (LEAD). . . . . . . . . . . . 4-49

4.13 CENTRAL WASTE COMPLEX STORED LOW-I.EVEL, TRANSURANIC,
AND POLYCHLORINATED BIPHENYL WASTE

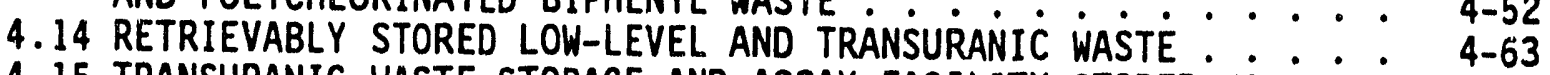

4.15 TRANSURANIC WASTE STORAGE AND ASSAY FACILITY STORED WASTE : 4-69

4.16 303-K STORED WASTE ................... 4-... 43

5.0 REFERENCES ....................... . . . . 5-2

5.1 DOCUMENTS 5 .

5.2 CODE OF FEDERAL REGULATIONS AND FEDERAL $\cdots \cdot \cdots \cdot \cdots$

5.3 FEDERAL AND STATE ACTS

5.4 WASHINGTON ADMINISTRATIVE CODE . . . . . . . . . . . . . . $5-5$

\section{FIGURES}

3-1 Permitting Schedules for Units Managing Land Disposal Restricted Waste .........

3-2 Operating Schedules for Units Managing Land Disposal Restricted Waste . . . . . . . . . . . . . F3-2

3-3 Double-Shell Tank Waste Treatment Flow Diagram . . . . . . . . . . . F3-3

3-4 PIJREX Aging Waste Treatment Flow Diagram . . . . . . . . . . . . . F3-4

3-5 Double-Shell Tank Waste Treatment Schedule ............. . F3-5 
3-6 Single-Shell Tank Waste Treatment Flow Diagram . . . . . . . . F3-6

3-7 Central Waste Complex, Retrievably Stored Waste,

183-H Solar Basin Waste, and 303-K Stored Waste

Treatment Flow Diagram ................. . F3-7

4-1 Double-Shell Tank Waste Disposal Flow Diagram . . . . . . . . F4-2

4-2 Process Flow Diagram for Disposal of Double-Shell Tank Waste . . F4-2

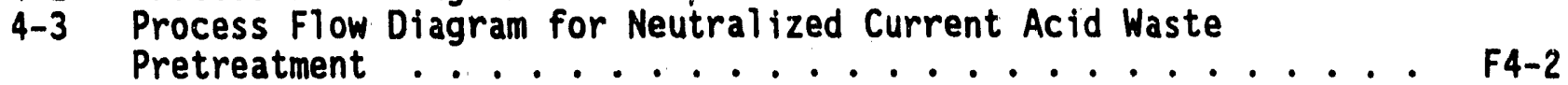

4-4 PUREX Aging Waste Transfers to Aging Waste Storage . . . . . . F4-2

4-5 Relative Proportions of Supernatant, Sludge and Saltcake in

Single-Shel1 Tank Waste . . . . . . . . . . . . . F4-2

4-6 Single-Shell Tank Waste Inventory by Tank Farm . . . . . . . F4-2

4-7 Process Flow Diagram for 242-A Evaporator Waste Treatment . . . . F4-2

4-8 Historical Process Flow Diagram for PUREX Ammonia Scrubber Waste Generation .. . . . . . . . . . . . . . . . . F4-2

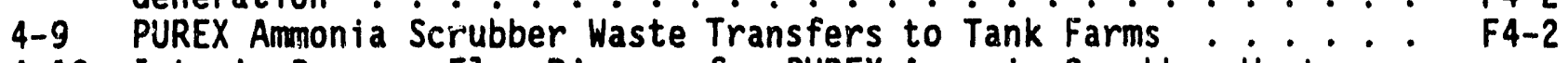

4-10 Interim Process Flow Diagram for PIJREX Ammonia Scrubber Waste

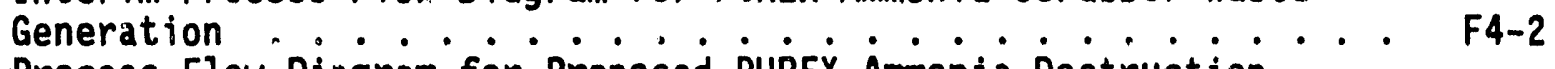

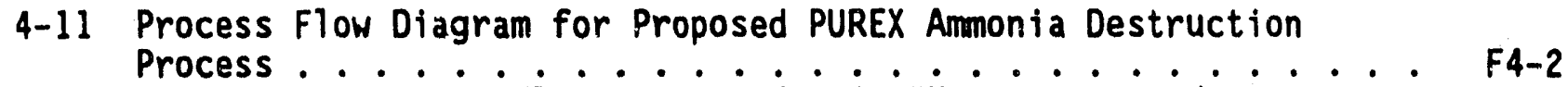

4-12 Histcrical Process Flow Diagram for PUREX Process Condensate
Generation . . . . . . . . . F4-2

4-13 Interim Process Flow Diagram for PUREX Process Condensate Generation ............. . F4-2

4-14 Process Flow Diagram for Future PUREX Process Condensate Generation ........................ . . F4-2

4-15 Process Flow Diagram for Hexone Waste Processing and Disposal - . F4-2

4-16 Conceptual Layout of the Central Waste Complex . . . . . . . F4-2

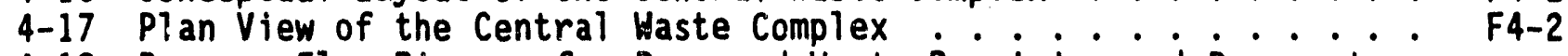

4-18 Process Flow Diagram for Proposed Waste Receiving and Processing Facility Module II . . . . . . . . . . . . . . . . F4-2

4-19 Typical Configuration of a Retrievabie Storage Unit for Contact-Handled Waste .. . . . . . . . . . . . . F4-2

4-20 Typical Configuration of a Retrievabie Storage Unit for Remote-Handled Waste ... . . . . . . . . . . F4-2

4-21 Transuranic Storage and Assay Facijity Fioor Pian . . . . . . F4-2

\section{TABLES}

2-1 Stream Names for the Hanford Land Disposal Restrictions Plan for Mixed Wastes. . . . . . . . . . . . . . . . T2-1

2-2 Relationship of Streams in the Hanford Land Disposal Restrictions Plan for Mixed Wastes to Those Previously Reported in the National Report and the "Thirds" Report. . . . T2-2

3-1 Summary of Annual Waste Generation Projections. . . . . . . . . T3-1

3-2 Waste Stream Characterization. . . . . . . . . . . . . T3-2

3-3 Hazardous Waste Designations of Plan Waste Streams. . . . . . . . T3-3

3-4 Storage Unit Characteristics. . . . . . . . . . . . . T3-4

3-5 Stored Waste Characteristics................ . T3-5 
3-6 Treatment of Land Disposal Restricted Waste for Disposal. . . . T3-6

3-7 Waste Minimization Activities for Hanford Land Disposal

Restricted Mixed Wastes. ................. T3-7

4-1 Projected Generation of Double-Shell Tank Waste. . . . . . . . : T4-1

4-2 Chemical Concentrations in Double-Shell Tank Waste. . . . . . T4-2

4-3 PUREX Aging Waste Composition ............... . . T4-3

4-4 Sample Analysis for PUREX Aging Waste

Stored in Tanks 241-AZ-101 and 241-AZ-102. . . . . . . . . . T4-4

4-5 Estimated Mass of Nonradioactive Chemical

Components of Existing Single-Shell Tank Waste

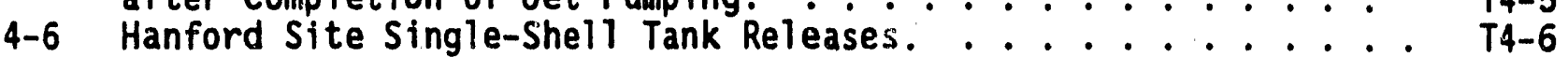

4-7 Analytes Detected in 242-A Evaporator Process Condensate. . . . . T4-7

4-8 Analytes Reported in PUREX Ammonia Scrubber Discharge. . . . . T4-8

4-9 Analyses For PUREX Ammonia Scrubber Feed Stored in

Double-shell Tanks. . . . . . . . . . . . . . . . T4-9

4-10 Analytes Reported in the PUREX Process Condensate. . . . . . . T4-10

4-11 Analyses of Hexone Waste. . . . . . . . . . . . . . . T4-11

4-12 Routine Wastes Discharged to 183-H Solar Basins. . . . . . . . T4-12

4-13 Listed Wastes Discharged into the 183-H Solar Basins. . . . . . T4-13

4-14 183-H Basin Number 1 Solids Samples:

Constituents Greater than One Percent. . . . . . . . . . . T4-14

4-15 183-H Basin Number 2 Sludge Samples:

Sol id Constituents Greater than One Percent. . . . . . . . . . T4-15

4-163-H Basin Number 3 and 4 Sludge Samples:
Major Inorganic Constituents. . . . . . . . . . . . T4-16

4-17 183-H Basin Number 2 Liquid Samples:

4-18 183-H Basin Number 2 Liquid Sampies:

Trace Inorganic Constituents. . . . . . . . . . . . . T4-18

4-19 PUREX Tunnels 1 and 2 Waste (Lead and Silver) T4-19

4-20 Projected Generation of Centrai Waste Complex

Stored Low-level and Transuranic Waste. . . . . . . . . T4-20

Currently in Storage at the Central Waste Complex. . . . . . . T4-21

4-22 Quantities and Designation of Transuranic Waste
Currently in Storage at the Central Waste Complex. . . . . . T4-22

4-23 Quantities and Designation of Low-Level Waste

Currently in Storage at the Retrievable Storage Units. . . . . T4-23

4-24 Quantities and Designation of Transuranic Waste

Currently in Storage at the Retrievable Storage Units. . . . , T4-24

4-25 Quantities and Designation of TRUSAF Stored Waste. . . . . . T4-25

4-26 Quantities and Designation of 303-K Facility

Stored Waste. . . . . . . . . . . . . . . . T4-26 


\section{ACRONYMS}

ECOLOGY

EPA

PUREX

RCRA

TCLP

TRUSAF

WAC
Washington State Department of Ecology U.S. Environmental Protection Agency Plutonium-Uranium Extraction Resource Conservation and Recovery Act Toxic Characteristic Leach Procedure Transuranic Waste Storage and Assay Facilities Washington Administrative Code

\section{DISCLAIMER}

This report was prepared as an account of work sponsored by an agency of the United States Government. Neither the United States Government nor any agency thereof, nor any of their employees, makes any warranty, express or implied, or assumes any legal liability or responsibrocess disclosed, or process disclosed, or represents that its use would not infringe privately owned rights. Reference herein to any specific commercial product, process, or service by trade name, trademark, mendation, or favoring by the United States Government or any agency thereof. The views United States Government or any agency thereof. 


$$
\text { DOE/RL-90-41 }
$$

\subsection{EXECUTIVE SUMMARY}

Since the early 1940s, the Hanford Site has been involved in the production and purification of nuclear defense materials. These production activities have resulted in the generation of large quantities of liquid and solid radioactive mixed waste. This waste is subject to regulation under authority of both the Resource Conservation and Recovery Act of 1976 (RCRA) and the Atomic Energy Act.

The State of Washington Department of Ecology (Ecology), the U.S. Environmental Protection Agency (EPA), and the U.S. Department of Energy (DOE) have entered into an agreement, the Hanford Federal Facility Agreement and Consent Order (Tri-Party Agreement) to bring Hanford Site Operations into compliance with dangerous waste regulations (Ecology et a1. 1989). The Tri-Party Agreement was amended to require development of the Hanford Land Disposal Restrictions Plan for Mixed Wastes (this plan) to comply with land disposal restrictions requirements for radioactive mixed waste. The Plan requirements are summarized below.

The Tri-Party Agreement requires, and the this $\mathrm{Plan}$ provides, the following sections:

- Waste Characterization Plan - Provides information regarding the timing for characterizing each land disposal restricted mixed waste. The sampling and analysis methods and protocols and a schedule for providing the characterization information, where available, are discussed.

- Storage Report - Identifies and describes the mixed waste at the Hanford site, including the following: the RCRA dangerous waste code(s), process information necessary to identify the waste and make land disposal restriction determinations, quantities stored, generation rates, location and method of storage, an assessment of storage unit compliance status, storage capacity, and the bases and assumptions used in making the estimates. The report is consistent with the data submitted in the National Report on Prohibited Wastes and Treatment Options (DOE 1990) and the "Thirds" Wastestream Data Input Forms (WHC 1990k).

- Treatment Report - Identifies the current treatment processes, plans, and scheduies for developing treatment technologies that meet land disposal restriction treatment standards.

- Waste Minimization PIan - Identifies methods for minimizing the generation of 1 and disposal restricted waste. Includes process changes made or planned to reduce the generation of land disposal restricted waste, methods to minimize the volume of land disposal restricted waste, and methods to minimize the toxicity of newly generated waste.

- Schedule - Provides schedules depicting the events necessary to achieve compliance with land disposal restriction requirements, 
including variances, exemptions, or time extensions necessary to achieve land disposal restrictions compliance.

The Hanford Site waste primarily resulted from defense materials production. Usable defense materials were separated from fission products waste through precipitation and solvent extraction processes. Large quantities of liquid waste resulted from these separation processes and were stored in underground single-shell tanks and double-shell tanks. Additional waste volumes resulted from nuclear fuel fabrication activities, process laboratories activities, decontamination and cleaning of equipment and building structures, closure of process and storage units, and research and development activities such as the Fast Flux Test Facility.

Future waste generation rates depend upon plant operating plans. Projected generation rates range from approximately 5,000 cubic meters per year during 1990 (when most plants are shut down) to approximately 80,000 cubic meters per year during 1995, assuming plant operations resume. The impact of the decision to place the Plutonium-Uranium Extraction (PUREX) Plant in standby on future waste operations will be addressed in the annual Land Disposal Restrictions Report.

The waste includes waste designated as characteristic dangerous waste; waste designated as toxic, carcinogenic, and persistent by the Washington State criteria; and waste designated as listed waste because it contains small amounts of spent solvents and discarded pure chemical products. The waste consists of liquid, sludges, hard crystall ine material (salt cake), contaminated equipment, paper, rags, etc. Much is alraady known about the waste characteristics from process information and sampling and analysis programs. Action schedules have been developed to further characterize the waste.

The waste is currently (1990) stored in underground single-shell tanks and double-shell tanks, in containers placed in storage units such as the Central Waste Complex, cassions, and retrievable storage units. A surface impoundment, the Liquid Effluent Retention Facility, is being constructed to store large quantities of waste that contain radionuclide concentrations low enough to allow surface storage. The waste will be removed from these storage units, treated to meet land disposal restriction standards, and sent to final disposal in accordance with schedules established in the Tri-Party Agreement.

Total Hanford Site storage capacity for land disposal restricted waste is approximately 570,000 cubic meters. Approximately 240,000 cubic meters of waste are currentiy in storage. The double-shell tanks are anticipated to be filled to capacity in 1997. The Liquid Effluent Retention Facility basins dedicated to 242-A Evaporator process condensate will be filled in 1991 and the storage space currently available at the Central Waste Complex is anticipated to be filled in 1996; however, adoitional buildings will be constructed as required to store waste generated in the future.

The waste treatment procasses for these wastes include the current treatment processes to reduce corrosion of storage tanks and planned treatment processes to reduce waste toxicity and immobilize waste constituents. Current waste treatment consists of $\mathrm{pH}$ and corrosion 
inhibitor, concentration adjustments, and use of absorbents and solidifying agents. Planned waste treatment processes include the following: development of neutralization and toxic constituent destruction processes [PUREX Plant ammonia destruction and corrosivity neutralization processes], development of waste separation and pretreatment processes (B Plant, Waste Receiving and Processing Facility), use of a large-volume solidification unit for low-activity liquid waste (the Grout Treatment Facility), use of a vitrification plant to treat high-activity and transuranic double-shell tank waste (the Hanford Waste Vitrification Plant), and development of an organic destruction process (the Effluent Treatment Facility).

The Hanford Site has developed a Site-wide waste minimization plan that sets minimization goals and establishes processes for measuring progress toward these goals. Each plant or process has developed a plan to implement the Site-wide goals. Current (1990) waste minimization plans are expected to reduce dangerous waste generation by approximately 100,000 cubic meters per year.

Hanford Site First, Second, and Third Third mixed waste, which include characteristic wastes are all subject to the 2-year national capacity variance (52 FR 22520). California 1ist waste (40 CFR 268.32) and solvent waste at the Hanford Site (40 CFR 268.30) are not covered by the national capacity variance. The continued storage of these wastes until sufiicient treatment and disposal capacity is available for these wastes was negotiated as part of the Tri-Party Agreement (Ecology et al. 1989). Schedules to implement the dangerous waste management compliance activities until treatment capacity is available are described in this Agreement. Any newly identified compliance actions will be scheduled in accordance with procedures established in the agreement (Ecology et al. 1989). 


\subsection{INTRODUCTION}

The Plan was prepared in accordance with Tri-Party Agreement milestone M-26-00 (Ecology et a1. 1989). The text of this milestone is as follows.

Land disposal restriction requirements include limitations on sturage of specified hazardous wastes (including mixed wastes). In accordance with appioved $p l$ ans and schedules, DOE shall develop and implement technologies necessary to achieve full compliance with 1 and disposal restriction requirements for mixed Wistes at the Hanford Site. Land disposal restriction plans and schedules shall be developed with consideration of other action plan milestones and will not become effective until approved by EPA (or Ecology upon authorization to administer land disposal restriction pursuant to Section 3006 of RCRA). Disposal of land disposal restriction wastes at any time is prohibited except in accordance with applicable land disposal restriction requirements for nonradioactive wastes at all times. The Plan will include, but not be limited to the following:
a. Waste Characterization Plan
b. Storage Report
c. Treatment Report
d. Treatment P1an
e. Waste Minimization Plan
f. A schedule, depicting the events necessary to achieve full compliance with land disposal restriction requirements
g. A process for establishing interim milestones

This Plan is a follow-on document to both the National Report on Prohibited Wastes and Treatment Options (DOE 1990), which identified all solvent (40 CFR 268.30) and California list (40 CFR 268.3र́) wastes that are restricted from land disposal, and a subsequent effort by the DOE (WHC 1990k) to identify any additional waste that was restricted from land disposal as a result of first, second, and third third land disposal restrictions promulgation ( 55 FR 22520).

\subsection{BACKGROUND AND PURPOSE}

On September 19, 1989, the DOE entered into a federal facilities compliance agreement with the EPA and the Colorado Department of Health regarding the storage of certain radioactive mixed waste at the Rocky fiats Plant. Section VI.E of the agreement required the DOE to prepare and submit to the EPA the National Report on Prohibited Wast os and Treatment Options. This report was submitted to EPA in January of 1990. The National Report (DOE 1990) included information on all DOE sites that store radioactive mixed waste subject to the land disposal restrictions in effect at the time of report preparation.

Sin a that time, additional land disposal restrictions for dangerous waste have been promulgated by the EPA ( 55 FR 22520). These restrictions resulted in additional waste being restricted from 1 and disposal. These 
wastes were not included in the National Report. To assess the impact of these new restrictions on the DOE facilities, a survey of all DOE sites was conducted by the DOE to identify any additional waste that was restricted from land disposal as a result of this Thirds rule. The data from this survey, commonly called the "Thirds Report," (WHC 1990k) currenily are being used by DOE together with the National Report to prepare a database t'lat will describe the type, quantities, and treatment plans for all 1 and disposal restricted waste generated by DOE facilities.

This Plan is a detailed description of the generation and management of land disposal restricted mixed waste generated, treated, and stored at the Hanford Site. This report discusses the land disposal restricted waste (mixed waste) managed at the Hanford Site by point of generation and current storage locations. The waste is separated into groups based on the future treatment of the waste before disposal. This grouping resulted in the definition of 16 groups or streams of 1 and disposal restricted waste. The 16 stream names used for this plan are shown in Table 2-1.

The wastestreams identified for this Plan combine several of the wastestreams identified in the National Report and the Thirds Report. The relationship among the stream names used for this Plan and those used for the National Report and the Thirds Report is shown in Table 2-2. Table 2-2 indicates that some of the streams included in the National Report were not included in the Thirds Report and vice versa. These exclusions are not due to errors in compiling the reports but are due to a difference in the scope of the reports. The National Report included Solvent waste (40 CFR 268.30) and California list (40 CFR 268.32) wastes, whereas the Thirds Report was to include all nonsolvent waste that was restricted from land disposal. This report encompasses the Hanford Site-specific aspects of the National Report and the Thirds Report, as well as newly identified land disposal restricted waste.

\subsection{ASSUMPTIONS}

This section lists key milestones and assumptions used in the preparation of this Plan. The assumptions are as follows.

The Tri-Party Agreement (Ecology et al. 1989) milestones will be met as identified in the approved work schedules of the Tri-Party Agreenent. The following are key milestones related to the management of land disposal restricted waste identified in the Tri-Party Agreement:

- Complete 14 grout campaigns of double-shell tank waste by September 1994 (M-01-00).

- Initiate B Plant operations for pretreatment of neutralized current acid waste by October 1993 (M-02-00).

- Initiate Hanford Waste Vitrification Plant operations by December 1999 (M-03-00).

- Complete single-shell tank interim stabilization by September 1995 (M-05-00). 
- Initiate full-scale demonstration of waste retrieval technology by October 1997 (M-07-00).

- Complete analysis of at least two core samples from each singleshell tank by September 1998 (M-10-00).

- Complete construction and initiate operations of expanded laboratory hot cells by June 1994 (M-11-00).

- Complete construction and initiate operations of a low-level mixed waste laboratory by January 1992 (M-14-00).

- Complete Waste Receiving and Processing Module I construction and initiate operations by September 1996 (M-18-00).

- Complete Waste Receiving and Processing Module II construction and initiate operations by September 1999 (M-19-00).

The following are key assumptions that have heen used to develop the treatment plans and schedules for double-shell tank waste (WHC 1989a):

- The transuranic-extraction process is an acceptable technology for the removal of transuranic elements from neutralized cladding removal waste, Plutonium Finishing Plant waste, and complexant concentrate waste.

- The Hanford Waste Vitrification Plant will be able to treat neutralized current acid waste, neutralized cladding removal waste, Plutonium Finishing $\mathrm{Pl}$ ant waste, and complexant concentrate waste without blending.

- Organics in complexant concentrate waste can be destroyed by a high-temperature and pressure process, an ozonization process, or a hydrogen peroxide process.

- A system of two mixer pumps will satisfactorily mobilize doubleshell tank sludges.

- Double-shell slurry does not require pretreatment before grout disposal.

- Double-shell tank space will be available to support all doubleshell tank waste disposal activities.

- The Hanford Waste Vitrification Plant process equipment will be provided to remove transuranic elements from the Hanford Waste Vitrification Plant process effluent streams, and process effluents from Hanford Waste Vitrification Plant operations can be disposed of at the Grout Treatment Facility without additional treatment.

- The following waste types will be pretreated prior to disposal at B Plant: neutralized current acid waste (1993), neutralized cladding removal waste (1997), Plutonium Finishing Plant (1999), and complexant concentrate (2000). 
The following are key assumptions with respect to the generation of double-shell tank waste and the utilization of tank space:

- The 242-A Evaporator will restart in December $1990^{1}$.

- The Liquid Effluent Retention Facility will be available in December 1990 to store 242-A Evaporator process condensatel.

- A treatment unit for 242-A Evaporator process condensate will be available in October $1993^{1}$.

- On October 16, 1990, the Secretary of Energy announced the preparation of an Environmental Impact Statement to ensure proper environmental consideration before selection of an appropriate management, treatment, and disposition option for the stored reactor fuel at the Hanford Site.

- During the course of the Environmental Impact Statement process, the PUREX Plant, as one of the options, will be placed in a standby condition.

- During PUREX Plant standby, no PUREX aging waste, PUREX process condensate, or PUREX ammonia scrubber waste will be generated. Future PUREX process condensate and PUREX ammonia scrubber condensate streams will not be dangerous wastes.

- Waste generation projections for PUREX PIant operations, if selected as the preferred option, will be based on plant configuration changes and upgrades to be considered during the course of PUREX Plant restart planning.

\subsection{SCHEDULE AND MECHANICS OF PLAN UPDATE}

Information in this $\mathrm{Plan}$ will be updated by an annual report in accordance with Tri-Party Agreement milestone M-26-01. The annual reports are expected to include the following:

- Addition of new 1 and disposal restricted wastestreams as they are identified

- Revision of the stream generation rates to reflect current operating $\mathrm{plans}$ and schedules

- Revision to treatment $\mathrm{pl}$ ans and schedules to reflect further defined waste treatments and treatment schedules

1The start-up and operating schedules for these facilities currently are being reevaluated. 
- Ravision to the stream characterizations to reflect additional sample analyses or process changes

- Revision to the compliance status of the units to reflect future compliance assessments and permitting activities

- Reevaluation of the adequacy of the capacity of current units for the storage of land disposal restricted waste.

The annual report also will include a description of activities and achievements for compliance with land disposal restrictions requirements for the period of October 1 through September 30 eacii year.

\subsection{MILESTONE PLANNIMG PROCESS}

Milestones and work schedules for activities related to the management of land disposal restricted mixed waste shall be consisten't with the comprehensive work schedules contained in Appendix $D$ of the Tri-Party Agreement (Ecology et al. 1989) and the annual update to Work Schedule. The scope of these schedules includes interin: milestones and additional target dates to accomplish the major milestones contained in Section 2.0 of the Tri-Party Agreement. Sunmary milestone schedules for activities related to the management of 7 and disposal restricted mixed waste are discussed in chapter 3.0. Any new or additional land disposal restrictions milestones, as well as changes to approved land disposal restrictions milestone schedules, shali be implemented via the Change Control System process defined in Section 12.0 of the Tri-Party Agreement.

In addition to the procedural requirements of the Tri-Party Agreement, the land disposal restriction: milestone planning process exercised by the $D O E$ and its contractors also involves consideration of the DOE and federal budget process, integration with other concurrent Hanford Site operations (including waste management and environmental restoration activities) and overall Site-wide regulatory compliance and coordination with other milestone initiatives described in the Tri-Party Agreement. Because these planning elements are numerous and complex, coordination and resolution of issues shall be accomplished through the ongoing project managers' and unit managers' meetings within the broader framework provided by Section 8.0 of the Tri-Party Agreement. A? so, land disposal restricted waste managemen $c$ activities shall be included, as appropriate, in Tri-Party Agreement quarterly progress reports, and summarized each year, as required by milestone M-26-01, in the annual Hanford Land Disposal Restrictions Report for Mixed Wastes.

The annual work schedules will be coordinated with, and integrated into, the Appendix $D$ work schedule of the Tri-Party Agreement. The primary purpose of the annual report is to expand the level of detail, where available, for activities planned for the upcoming 12-month period. Appendix $D$ work schedule updates shall require approval by the project managers using the Change Control System process and shall be subject to the public comment process defined in Section 10.0 of the Tri-Party Agreement. 


\section{DOE/RL-90-41}

The initial update of 1 and disposal restrictions milestone schedules provided in this Plan shall be issued in October 1991, as required under milestone M-26-01. 
Table 2-1. Stream Names for the Hanford Land Disposal Restrictions Plan for Mixed Wastes.

1. Double-Shell Tank Waste

2. PUREX Aging Waste

3. Single-She11 Tank Waste (inventory in storage) ${ }^{a}$

4. 242-A Evaporator Process Condensate

5. 4843 Sodium Storage Facility Waste

6. PUREX Ammonia Scrubber Waste (inventory in DSTS) a

7. PUREX Process Condensate (inventory in DST) ${ }^{a}$

8. Hexone Waste (inventory) ${ }^{a}$

9. 183-H Solar Basin Waste (inventory) ${ }^{a}$

10. PUREX Tunnel 2 Waste (Mercury)

11. PUREX Tunnels 1 and 2 Waste (Lead and Silver)

12. PUREX Canyon Waste Pile (Lead)

13. Central Waste Complex Stored Low-Level, Transuranic, and PCB Waste

14. Retrievably Stored Low-Level and Transuranic Hastes (inventory)

15. TRUS AF Stored Waste

16. 303-K Stored Waste (inventory)

$P C B=$ polychlorinated biphenyl

PUREX = Plutoniun-Uranium Extraction

TRUSAF = Transuranic Waste Storage and Assay Facility

aNot currently being generated 


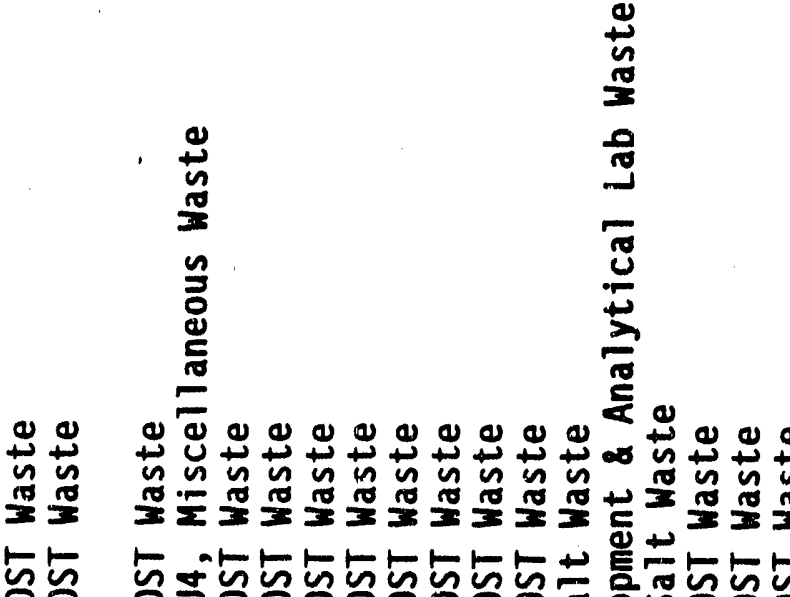

55

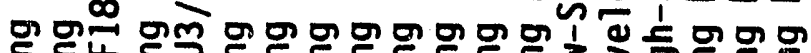

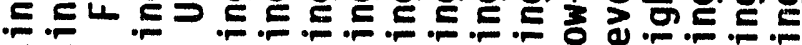

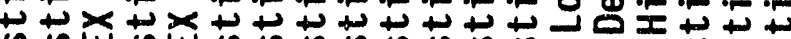

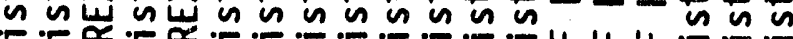

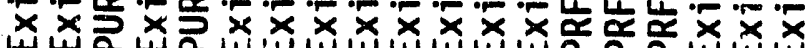
1

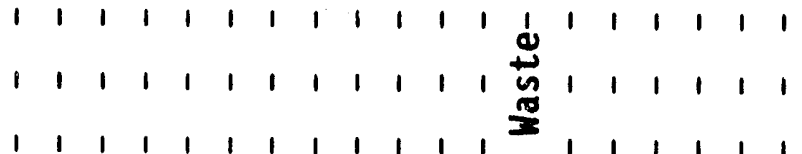
$\stackrel{1}{n} \sim 1$

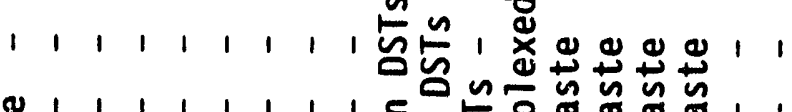

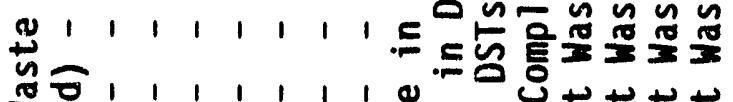
표 $=\frac{1}{3}$

둥

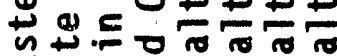

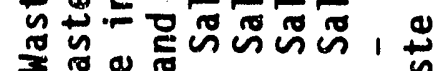

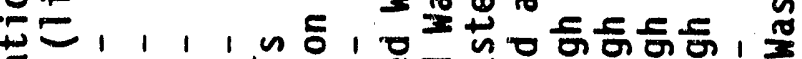

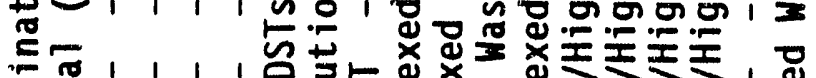

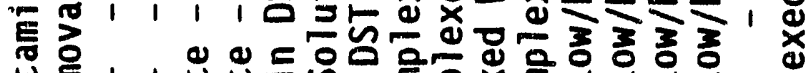

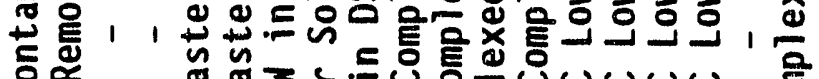

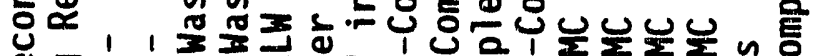

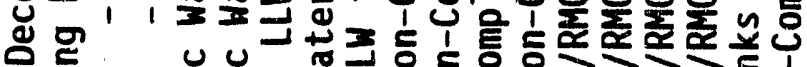

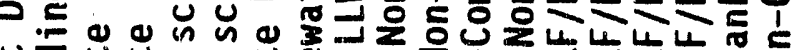

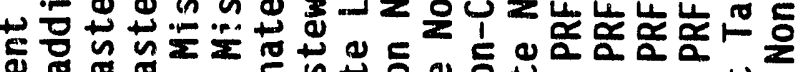

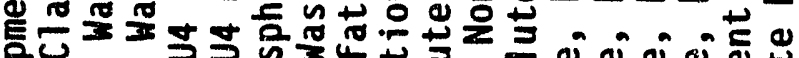

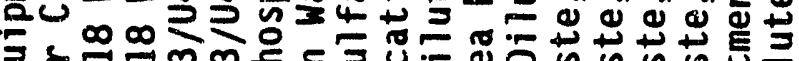

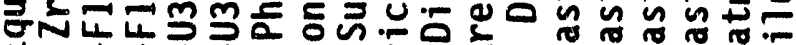

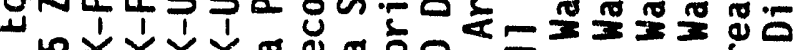

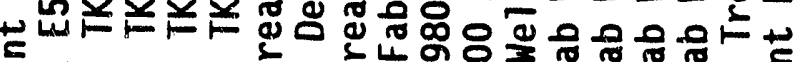

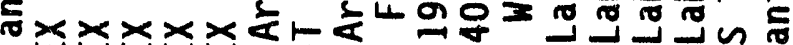

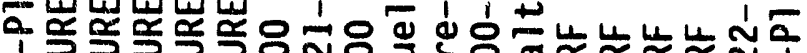

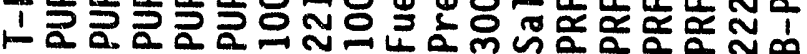

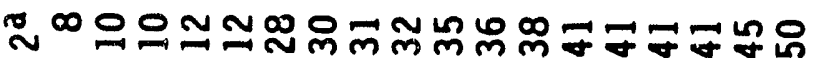

d) $\omega+\omega \omega$ I0

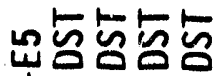
¿ ó on ד山 un 号

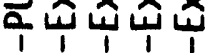


DOE/RL-90-41

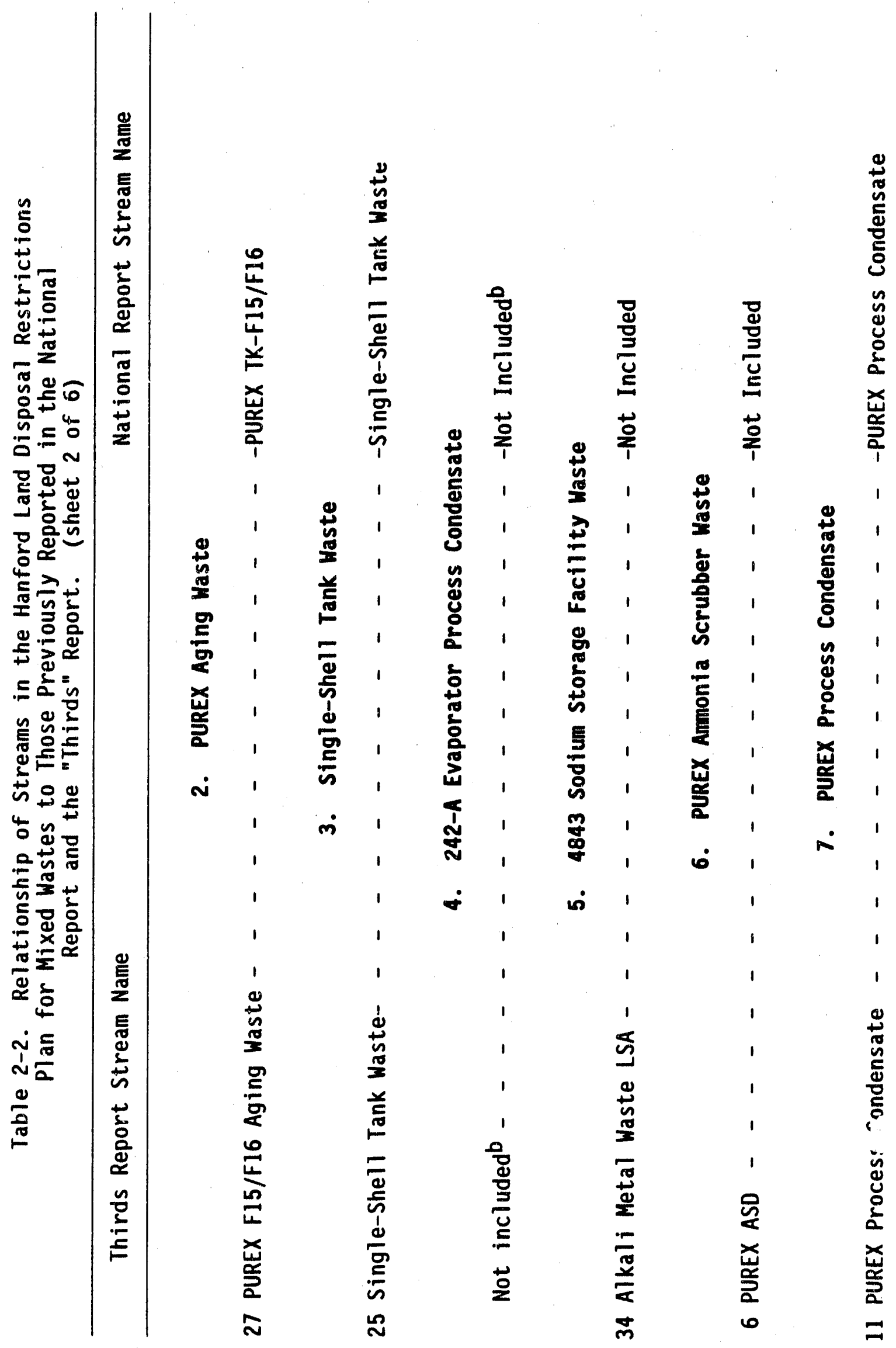




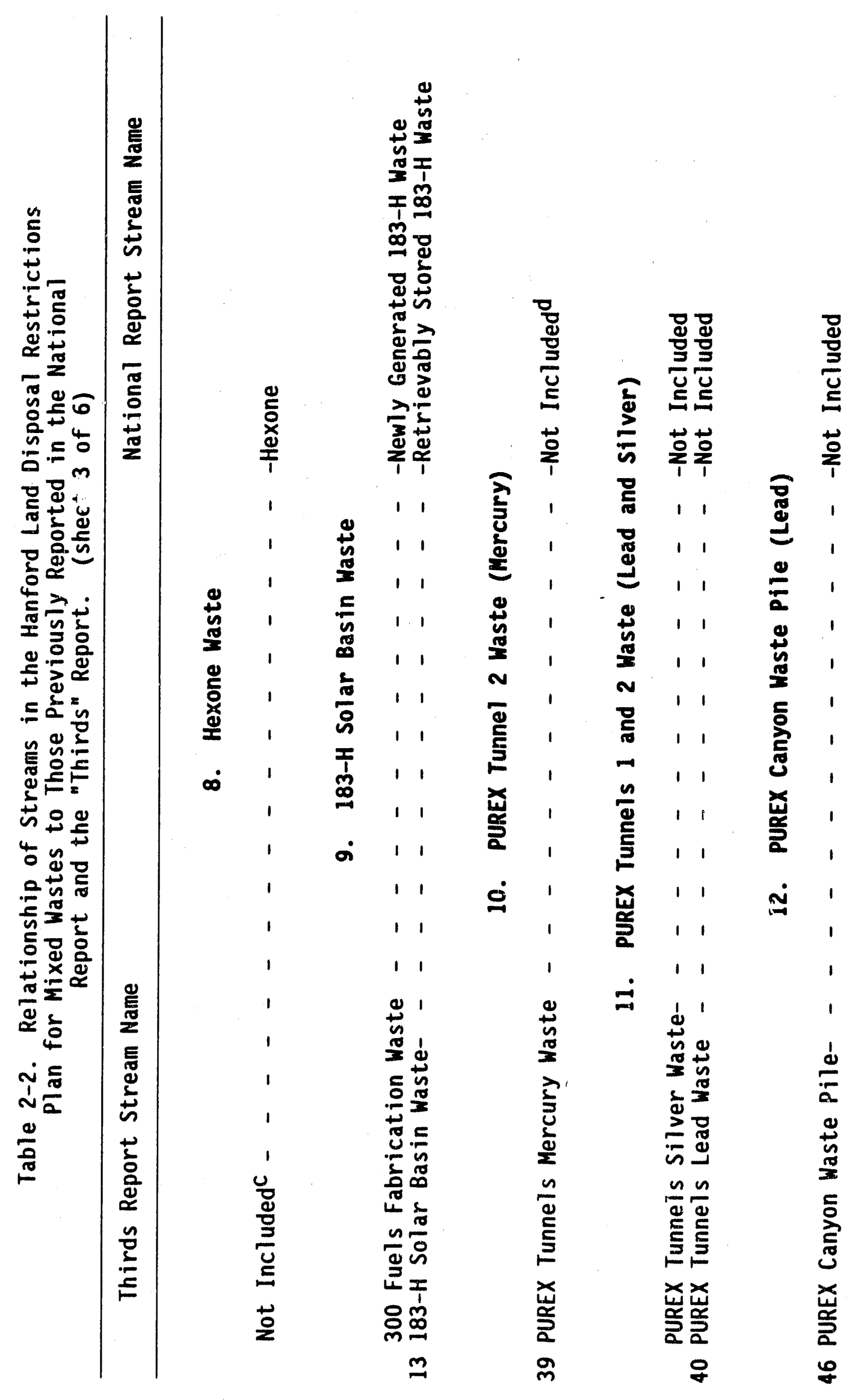



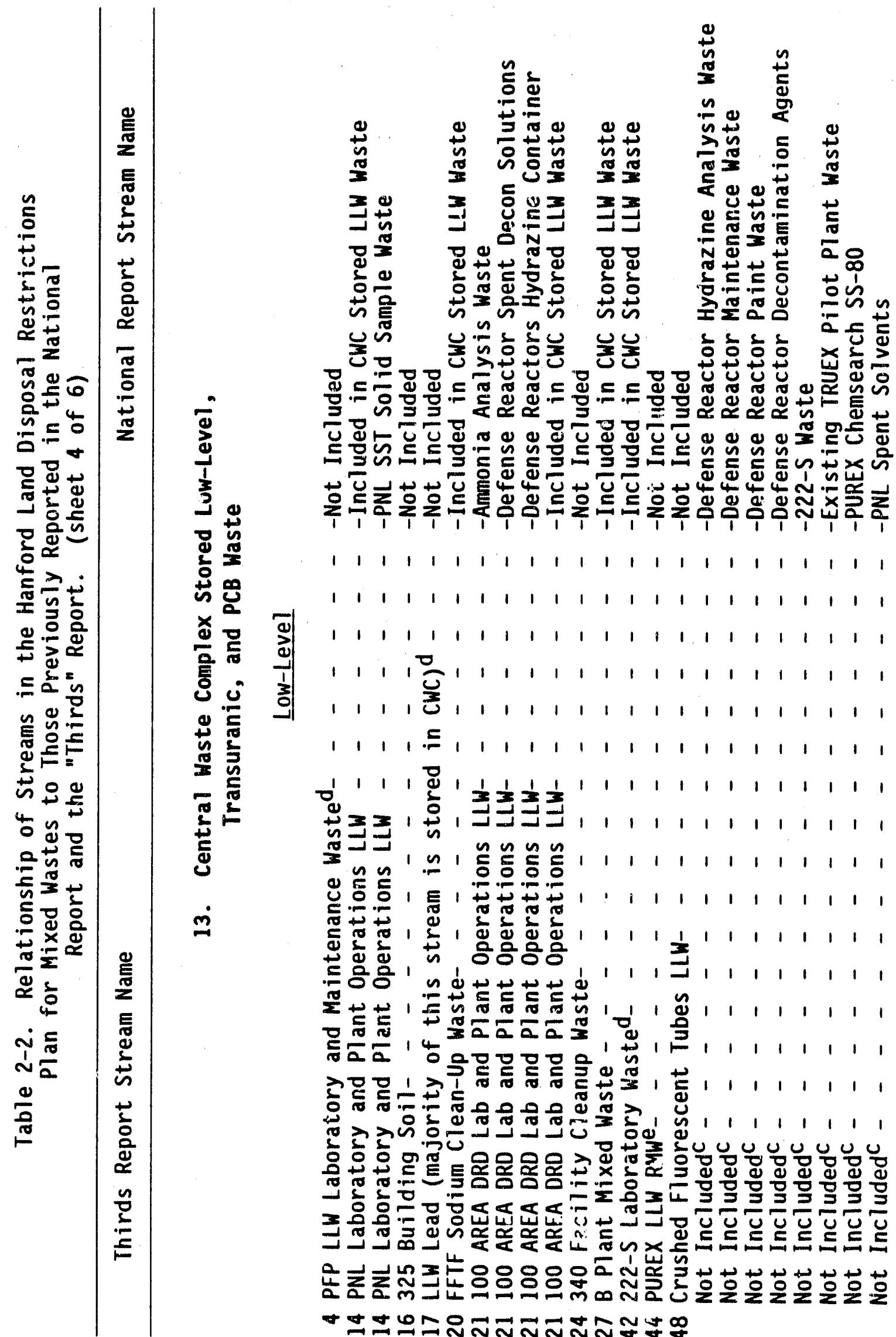

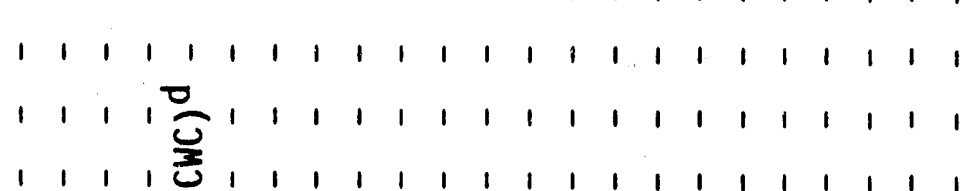

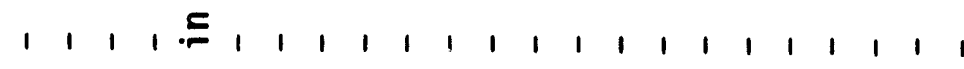

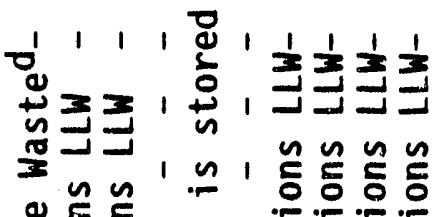

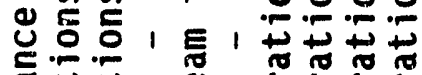

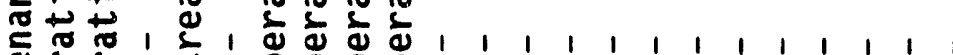

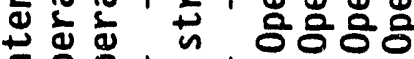

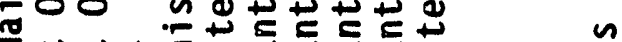

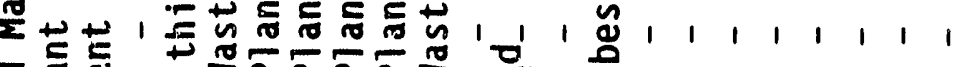

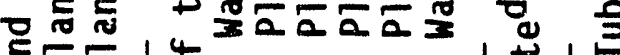

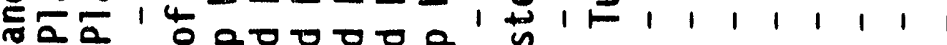

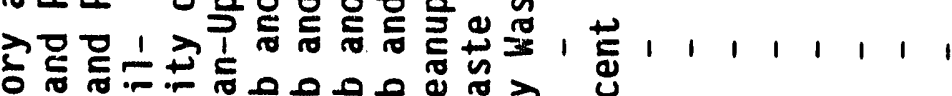

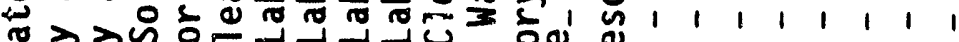

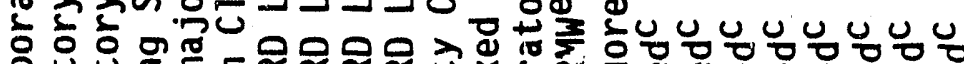

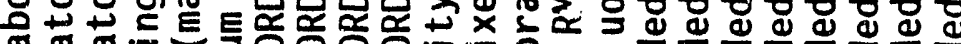
\%

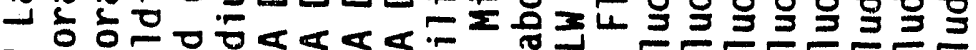

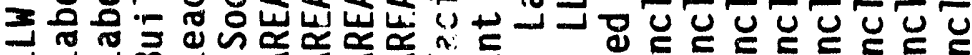

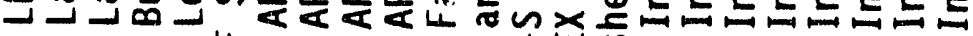

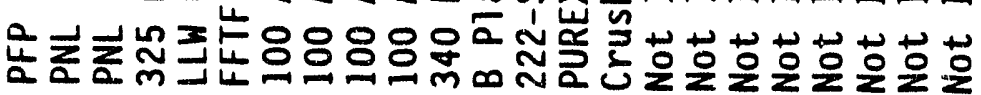

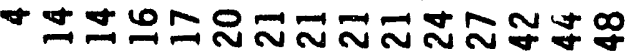




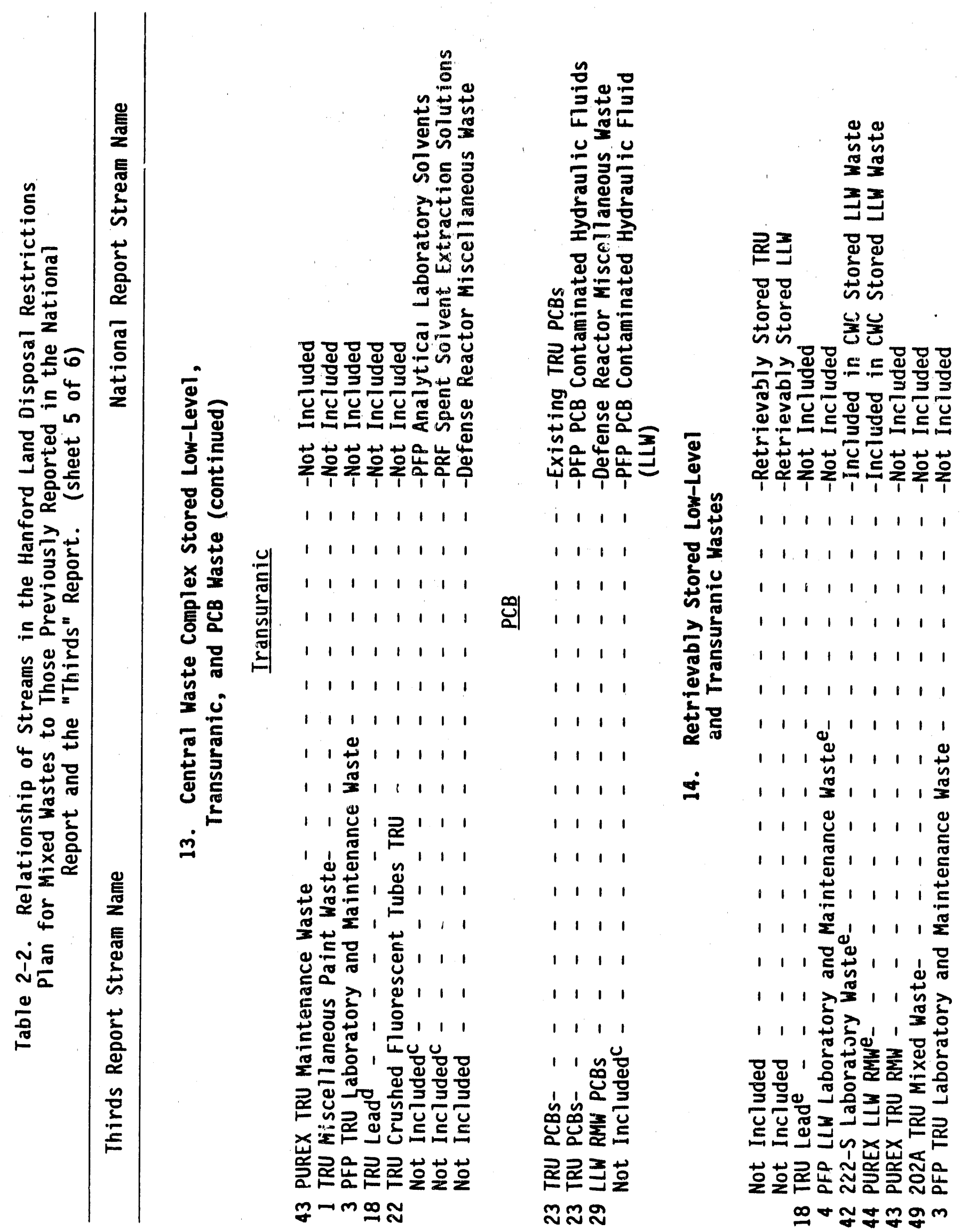




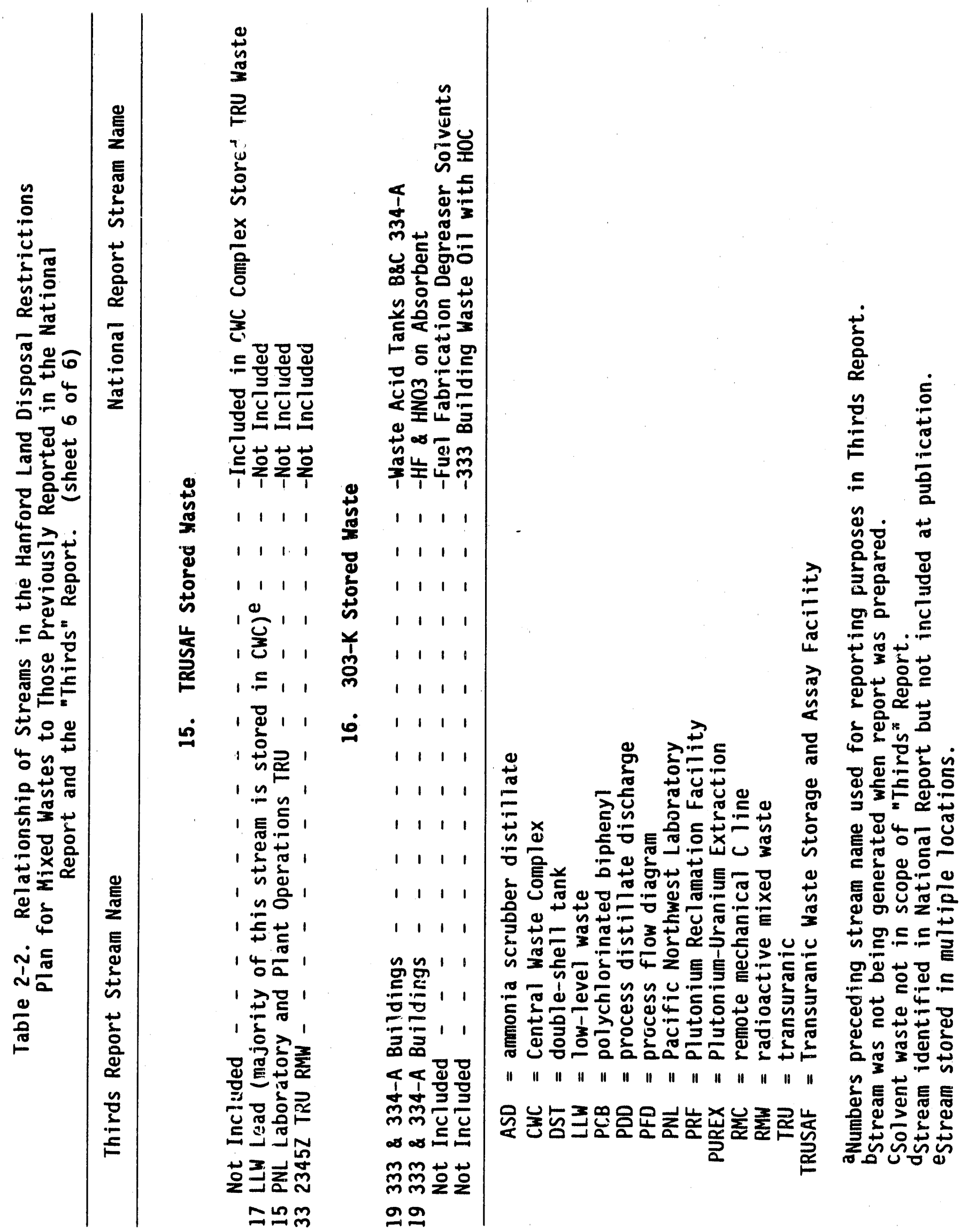


DOE/RL-90-41

\subsection{SITE SUMMARY}

This section summarizes the generation, characterization, storage, treatment, and minimization of radioactive land disposal restricted waste at the Hanford Site. It also discusses the variances, exemptions, and time extensions required to manage this waste within the requirements established by 52 FR 22520 and 40 CFR 268.

\subsection{WASTE GENERATION}

The projected volumes of radinactive mixed waste to be generated are shown in Table 3-1. The assumptions governing these generation rates are discussed in detail in Chapter 2.0, Section 2.2. The assumptions of Chapter 2.0, Section 2.2 can be summarized by the following three general statements:

- The operation of waste pretreatment (e.g., B Plant), treatment (e.g., Grout Treatment Facility, Hanford Waste Vitrification Plant, Waste Receiving and Processing), and disposal (e.g., Grout Treatment Facility) units will proceed as scheduled in the Tri-Party Agreement.

- It is the expectation of the EPA, the DOE, and Ecology that obligations of ihe DOE arising under the Tri-Party Agreement (Ecology et al. 1989) will be fully funded. The DOE shall take all necessary steps and make efforts to obtain timely funding to meet its obligations under the Tri-Party Agreement. Ecology and the EPA shall assist the Department of Energy/Richland Operations Office in determining the funding levels required to support the corresponding negotiated work schedule for each fiscal year. However, Ecology and the EPA will not become involved with the internal the DOE budget process, nor in the federal budget process as it proceeds from DOE to the Office of Management and Budget and ultimately to Congress through the President's submittal.

- Site production plants (e.g., Plutonium Finishing Plant) will continue to operate within their current planning bases.

The annual waste generation volumes presented in Table 3-1 represent the current best estiriates of future waste generation for each of the land disposal restricted mixed wastestreams. These estimates are based on detailed evaluation of $p$ ant operating schedules, past operating history, and projections of future waste generation. The projected generation volumes may be higher or lower than the actual generation rates because of changes in waste treatment or production schedules or waste minimization activities.

\subsection{WASTE CHARACTERIZATION}

The radioactive mixed waste at the Hanford Site has been characterized, as documented in this $\mathrm{Plan}$, based on current process 
knowledge and, where available, waste sample analyses. Sampling and characterization of the waste will continue until the waste is disposed. Future characterization plans for the waste are summarized in Table 3-2.

The dangerous waste designations for the waste in storage are summarized in Table 3-3. This table shows the dangerous waste codes applicable to each of the wastestreams. The assigned dangerous waste codes are based on the generation process and analyses of the wastestreams. The waste designations shown in this table are based on the best available information. However, future characterization of the waste may show that additional waste codes not indicated on the table are applicable to a wastestream and some of the waste codes indicated are not applicable to the wastestream. If additional waste codes are found to be applicable to a wastestream, they will be included in the next annual update of this Plan.

The use of the DOO1 (ignitable) waste code to characterize the waste stored in the single-shell tanks, tlie double-shell tanks, and the silver nitrate waste stored in the PUREX Storage Tunnels have been assigned the 0001 (ignitable) waste designation because of the presence of nitrates and/or nitrites. They are not believed to be ignitable in the strict sense of the word. The applicability of the DOOl (ignitable) designation of the waste is being investigated as part of the waste characterization programs.

The use of the $\mathrm{FOO}^{3}$ (spent nonhalogenated solvents) waste code to characterize the waste stored in the single-shell tanks and double-shell tanks has been assigned to the waste not because the waste contains significant quantities of spent nonhalogenated solvents, but because a small quantity of waste discharged to the tanks in the past may have contained spent nonhalogenated solvents. The potential for the past discharge of spent nonhalogenated solvents to have contaminated essentially all of the waste in the tanks has resulted in the waste being designated F003. The tank waste does not comprise large quantities of organic solvents, as is typically the case for waste designated F003. The tank waste is primarily inorganic in nature with trace contamination by $\mathrm{FOO}_{3}$ solvents.

The schedule and means for reporting waste characterization data are outlined in the Tri-Party Agreement (Ecology et al. 1989) as amended by new Section 9.6, Data Reporting Requirements. This section states that the DOE will make available to Ecology and the EPA a 11 validated laboratory analytical data collected pursuant to the Tri-Party Agreement within 15 days of data validation. Within 1 week after the laboratory data are validated, the DOE will notify Ecology and EPA of its availability. This notification will include the time and location of the sampling, the type of data available, and a list of the sample parameters or a target compounds list. The time limits for reporting sample analyses are single-shell tank analyses, 180 days; hot cell analyses, 100 days; low-level and mixed waste, 75 days (after the date of sampling).

The quality assurance requirements for sample analysis are defined in the Data Quality Strategy For Characterizing The Hanford Site, Appendix F to the Tri-Party Agreement (as amended in 1990). Before any sampling or analysis, the appropriate level of quality assurance/quality control will be defined and documented in accordance with Guidelines and Specifications for Preparing Quality Assurance Program Plans (EPA 1983a) and Interim Guidance 
and Specifications for Preparing Quality Assurance Project Plans, (EPA 1983b). All laboratories that analyze samples for DOE diso are required to have a Quality Assurance/Quality Control plan approved by the EPA and Ecology before being used to conduct analyses.

\subsection{WASTE STORAGE}

The Hanford Site has 15 units that currently store mixed waste. These 16 units can be divided into two groups: (1) 5 that no longer actively are receiving waste (single-shell tank waste, hexone waste, 183-H Solar Basin waste, retrievably stored low-level and transuranic waste, and 303-K stored waste) and (2) 11 that currently are receiving waste for storage to await treatment and disposal. The key characteristics of these units are summarized in Tahle 3-4.

Tine storage unit capacity for radioactive mixed waste at the Hanford Site is projected to be adequate for all currently generated mixed waste until 1996, assuming the availability of additional storage facilities. In 1991, the Liquid Effluent Retention Facility will be near its storage capacity for 242-A Evaporator process condensate (Chapter 4.0, Section 4,4). Current plans are to suspend 242-A Evaporator operations temporarily until treatment of the waste at the Effluent Treatment Facility can treat the stored Liquid Effluent Retention Facility waste and receive the process condensate from the 242-A Evaporator. After the Effluent Treatment Facility has treated the process condensate stored in Liquid Effluent Retention Facility (projected to be completed in 1994), it will treat the process condensate directly without further storage at the Liquid Effluent Retention Facility.

In 1997, the double-shell tanks are projected to reach their capacity for the storage of both aging waste (Chapter 4.0, Section 4.2) and nonaging waste (Chapter 4.0, Section 4.1). Options currently being addressed to ensure suificient aging-waste capacity are recucing the generation rate of aging waste and increasing the allowable concentration of the stored aging waste. If the PUREX Plant should restart and these options do not make sufficient space available, processing plans at the PUREX Plant will be adjusted to work within the available storage space. Options currently being investigated to ensure sufficient nonaging waste storage capacity include enhanced waste minimization and increased rate of grout disposal of existing waste. If these options do not make sufficient space available, processing plans for the operating plants (e.g., Plutonium Finishing Plant, B Plant) will be adjusted to work within the available storage space.

In 1996, the Central Waste Complex is projected to reach its capacity. This projection is based on the individual projections of all generators who ship waste to the Central Waste Complex. The projection of waste generation rates is refined annually. Should future projections indicate that increased storage capacity is required, additional storage units will be constructed and permitted on an as-needed basis.

The storage units for mixed waste at the Hanford Site have not released any dangerous constituents to the environment with the exception of the single-shell tanks and the 183-H Solar Basins. The single-shell tanks 
have released an estimated 2,600 cubic metere of liquid waste to the ground. This estimate excludes any cooling water added to tanks after they were known to be leaking. This volume estimate currently is being reviewed for accuracy and may be revised. To minimize further releases from this storage unit, the pumpable liquid portion of the waste stored in the single-shell tanks is being transferred to the double-shell tanks. The amount of hazardous constituents released from the 183-H Solar Basins has not been estimated as this time.

The Part B submittal date for mixed waste storage unit also is shown in Table 3-4. The date when each unit will be in full compliance with the interim status requirements is shown as the "Compliance Date" in Table 3-4. The date for submittal of the Part B permit application for each unit al so is indicated in the table. The schedule for the permitting "of the storage and treatment units currently used for mixed waste storage or planned for use in treating land disposal restricted waste is shown in Figure 3-1. The permitting and compliance schedules for these units have been negotiated as part of the Tri-Party Agreement (Ecology et al. 1989).

The general characteristics of the radioactive mixed waste currently in storage at the Hanford Site are summarized in Table 3-5. The table shows that the Hanford Site currently stores approximately 240,000 cubic meters of radioactive mixed waste. The bulk of this waste (99\%) is stored in the single-shell tanks (61\%) and double-shell tanks (38\%). The table also shows that of the waste currently in storage, $88 \%$ is low-level waste, $9 \%$ is transuranic waste, and $3 \%$ is high-level waste.

\subsection{WASTE TREATMENT}

The land disposal restrictions for dangerous waste (55 FR 22520 and WAC 173-303-140) specify a series of treatment technologies or treatment standards for each dangerous waste code that is restricted from 1 and disposal. If a treatment technology is specified for a waste code, that technology must be used to treat the waste before land disposal of the treatment residues. If a constituent concentration treatment standard is specified for a waste code, any treatment method may be used before land disposal so long as the treatment standard is met and so long as the waste is not impermissibly diluted. If a waste exhibits multiple waste codes, it must be treated in accordance with the technologies or constituent concentration standards associated with each of the waste codes present. For example, if a waste is ignitable (DOOI) and toxic characteristic leach procedure (TCLP) toxic for chromium (D008), the waste must be treated for both the characteristics of ignitability and TCLP toxicity.

This section summarizes the treacment standards applicable and those proposed for the Hanford Site waste; included are discussions of the following waste categories:

- Double-Shel1 Tank Waste (Chapter 4.0, Section 4.1)

- PUREX Aging Waste (Chapter 4.0, Section 4.2)

- Single-Shell Tank Waste (Chapter 4.0, Section 4.3)

- 242-A Evaporator Process Condensate (Chapter 4.0, Section 4.4)

- 4843 Sodium Storage Facility Waste (Chapter 4.0, Section 4.5) 
- PUREX Ammonia Scrubber Waste (Chapter 4.0, Section 4.6)

- PUREX Process Condensate (Chapter 4.0, Section 4.7)

- Hexone Waste (Chapter 4.0, Section 4.8)

- 183-H Solar Basin Waste (Chapter 4.0, Jection 4.9)

- PUREX Tunnel 2 Waste (mercury)

(Chapter 4.0, Section 4.10)

- PUREX Tunnels 1 and 2 Waste (lead and silver) (Chapter 4.0, Section 4.11)

- PUREX Canyon Waste Pile (lead) (Chapter 4.0, Section 4.12)

- Central Waste Complex Stored Low-Leve1, Transuranic, and Polychlorinated Biphenyl Waste (Chapter 4.0, Section 4.13)

- Retrievabiy Stored Low-Level and Transuranic Waste (Chapter 4.0, Section 4.14)

- TRUSAF Stored Waste (Chapter 4.0, Section 4.15)

- 303-K Stored Waste (Chapter 4.0, Section 4.16).

The applicable treatment standards (required by 55 FR 22520 and WAC 173-303-140) and the proposed treatments for the Hanford Site mixed waste are summarized in Table 3-6. The schedule for the operation of the treatment units is provided in Figure 3-2 (DOE/RL 1989f).

\subsubsection{Double-She11 Tank Waste}

The double-shell tank waste consists of high-level waste, transuranic waste, and low-level waste. Before treatment for disposal, some of the waste (e.g., complexant concentrate, aging waste) will be separated at B Plant into two streams. One stream is a low-level stream and the other is a transuranic and high-level stream. The low-level stream will continue to be evaporated at the 242-A Evaporator to concentrate waste and be solidified at the Grout Treatment Facility; the high-level and transuranic streams will be vitrified at the Hanford Waste Vitrification Plant.

Four waste types have been identified for feed vitrification, with preceding pretreatment: neutralized current acid waste, complexant concentrate, Plutonium Finishing Plant waste, and neutralized cladding removal waste. Each waste has certain chemical properties and constituents that require specialized pretreatment to reduce the disposal cost. This pretreatment is accomplished by separating these wastes into a low-volume, high-level, and transuranic waste fraction and a relatively high-volume, low-level waste fraction. Certain other double-shell tank waste types, such as double-shell slurry and phosphate-sulfate waste, are anticipated to be disposed directly as grout without pretreatment.

Before disposal, appropriate testing of the solidification treatment for low-level waste and vitrification for high-level waste will be conducted to ensure the disposed waste will comply with the land disposal restriction standards. The high-level waste subsequently will be disposed of at a repository; the transuranic waste subsequently will be dis, iosed of at the Waste Isolation Pilot Plant; and the low-level waste subsequently will be disposed of at the Grout Disposal Area located on the Hanford Site.

Figures 3-3 and 3-4 depict the double-she!l tank separation, treatment, and disposal processes. 
DOE/RL-90-41

Several Hanford Site plants are planned to perform treatment and disposal processes. The B Plant will be modified to perform the necessary waste separations. Initial pilot testing of some double-shell tank waste is scheduled to begin in 1993 and pretreatment operations are scheduled to begin in 1996. The Grout Treatment Facility will begin treating and disposing of low-level liquid waste in fiscal year 1991. The Hanford Waste Vitrification Plant is scheduled to begin treating high-level ind transuranic waste in December 1999; subsequent disposal of + ited highlevel waste will begin when a national repository is availaule, and disposal of treated transuranic waste is scheduled to begin when the Waste Isolation Pilot Plant is available for receipt of Hanford Site waste. The schedule for these treatment processes is shown in Figure 3-5 (WHC 1989a).

\subsubsection{PUREX Plant Aging Maste}

Treatment of the PUREX Plant aging waste is addressed in Section 3.4.1.

\subsubsection{Single-Shell Tank Waste}

The single-shell tank waste consists of low-level and transuranic liquid waste and low-level solids waste. The low-level and transuranic liquid waste will be transferred to the double-shell tanks and treated with other low-level and transuranic double-shell tank waste. The treatment will consist of separation into transuranic and low-level fractions at B Plant. The low-level liquid waste subsequentiy will be treated and disposed of at the Grout Treatment Facility. The transuranic liquid waste will be treated at the Hanford Waste Vitrification Plant and disposed of at Waste Isolation $\mathrm{Pil}$ ot Plant. The single-shell tank solids waste currently are being sampled and analyzed to determine the most effective means of retrieval, treatment, and disposal. An Environmental Impact Statement will be prepared evaluating alternatives and selecting the appropriate treatment and disposal technologies. Figure 3-6 depicts the single-shell tank treatment and disposal processes.

\subsubsection{2-A Evaporator Process Condensate}

The 242-A Evaperator process condensate waste (containing trace organic solvents) will be stored in a surface impoundiment (Liquid Effluent Retention Facility) for a short time while a treatment $p l a n t$ is constructed. The Effluent Treatment Facility is being designed and will be constructed and operated to destroy organic constituents and to remove curtain inorganic constituents. The Effluent Treatment Facility will treat the wastestreams to allow discharge to the ground. A petition is being prepared to delist the process condensate after it is treated.

\subsubsection{Sodium Storage Facility Waste}

The planned treatment for 4843 Sodium Storage Facility waste is deactivation by reacting it to form a sodium hydroxide/water solution and 
then reacting this solution with carbon dioxide to form sodium carbonate. The continued operation of the 4843 Sodium Storage Facility currently is being studied. Pending results of this study, the facility will continue to operate. Results of this study will be discussed in the annual report.

\subsubsection{PUREX Ammonia Scrubber Waste}

The PUREX ammonia scrubber waste is generated when ammonia gas from the $N$ Reactor fuel decladding process is sprayed with water. In the past, the ammonia-bearing solutions were boiled in a concentrator to separate the bulk of the enirained fission products from the ammonia scrubber discharge that was disposed in a crib. The remaining ammonia scrubber waste was transferred to doub?e-shell tanks.

In late 1987, it was determined that the ammonium hydroxide concentrations in the ammonia scrubber discharge sometimes exceeded $1 \%$, making it a dangerous (toxic) waste as designated by state regulations, and therefore not appropriate for discharge to the crib. The remaining ammonia scrubber feed was no longer concentrated for discharge, but treated for tank storage and transferred as ammonia scrubber waste to underground storage tanks. The treatment consisted of adding caustic to adjust the pH to greater than 12 and adding sodiuin nitrite to minimize tank corrosivity.

If the PUREX Plant restarts, plans for processing the ammonia scrubber stream will include ammonia destruction treatment process so that a significant portion of the stream will no longer be designated a dangerous or hazardous waste. The process will result in a much-reduced volume of dangerous waste stored in the double-shell tanks and a nordangerous stream that will be discharged to a Liquid Effluent Retention Faci?ity basin. The ammonia scrubber waste stored in the Liquid Effluent Retention Facility will be segregated from the 242-A Evaporator process condensate, a dangerous waste. The Effluent Treatment Facility will treat the ammonia scrubber waste removed from the Liquid Effluent Retention Facility before discharge to the ground.

\subsubsection{PUREX Process Condensate}

The PUREX process condensate is generated by condensing the vapors resulting from evaporative concentration of $N$ Reactor fuel solutions.

Until 1987, the PUREX process condensate stream was discharged direcily to a crib if radioactivity were sufficiently low. After closure of the old crib and to prevent corrosive ( $\mathrm{pH}<2$ ) waste from being discharged into the new crib, potassium hydroxide was added and the stream was routed through a tank with calcium carbonate (1 imestone) before being discharged. In early 1989 the stream was rerouted temporarily to underground storage tanks pending resolution of its dangerous waste designation.

If the PUREX Plant restarts, a neutralization process is planned for the waste. The treatment process will result in a nondangerous stream that will be discharged to a Liquid Effluent Retention Facility basin. The PUREX process condensate stored in the Liquid Effluent Retention Facility will be 
segregated from the 242-A Evaporator process condensate, a dangerous waste. The Effluent Treatment Facility will treat the PUREX process condensate removed from the Liquid Effluent Retention Facility before discharge to the ground.

\subsubsection{Hexone Naste}

Hexone waste currently is being removed from the storage tanks in 200 West Area and distilled to remove radionuclides, Following initial treatment, the waste will be incinerated offsite. The creatment will reduce the hexone to carbon dioxide and water. Spent distillation vessels will be sent to the Central Waste Complex for storage and treatment. Disposal will depend on the transuranic radionuclide content remaining after distillation. If the content is high enough to place the waste in the transuranic classification (greater than 100 nanocuries per gram), the vessels will be packaged for shipment to the Waste Isolation Pilot Plant. If not, they will be disposed in RCRA-complaint near-surface disposal unit.

\subsection{3-H Solar Basin Waste}

The 383-H Solar Basin waste, designated for ignitability, chromium, and trace listed commercial chemical products (formic acid, cyanide salts, vanadium pentoxide), results from closure of the 183-H Solar Basins storage unit. The contaminants and residues remaining in the 183-H Solar Basins are placed in containers and transported to the Centrai Waste Complex for storage. Subsequently, the waste will be treated at the Waste Receiving and Processing Facility and disposed of in a near-surface disposal unit. The required treatment technology for formic acid is incineration; therefore, a treatability variance will be required before ultimate disposal of this waste.

\subsubsection{PUREX Tunnel 2 Waste, PUREX Tunnels 1 and 2 Waste, and PUREX Canyon Waste Pile Stored Waste}

The PUREX Plant waste includes lead solids, mercury, and silver waste stored in the PUREX Tunnels and lead solids waste stored in the PUREX canyon waste pile. The required treatment for lead solids is macroencapsulation and/or surface decontamination. If surface decontamination is selected, the treatment residue must meet the lead characteristic treatment standard of 5 milligrams per liter. Amalgamation or retorting and recovery are the required treatments for mercury waste. Any treatrent that will achieve the constituent concentration limits is appiicable for the silver waste.

Treatment options for this waste are being reviewed. Treatments have not yet been selected. 


\subsubsection{Central Waste Complex Stored Low-Level, Transuranic and PCB Waste, and Retrievabiy Stored Lokt-Level and Transuranic Waste}

The Central Waste Complex stored waste consists of low-level and transuranic mixed waste and low-level and transuranic mixed waste that is contaminated with polychlorinated biphenyls. The Central Waste Complex stored waste will be separated at the Waste Receiving and Processing Facility into transuranic and low-level streams. The tran iuranic waste is stored at Transuranic Waste Storage and Assay Facilities and will be disposed of at the Waste Isolation Pilot Plant. The low-level waste will be disposed of in a near-surface disposal unit. Waste will be treated at the Waste Receiving and Processing Facility or maybe shipped to offsite treatment (e.g., for incineration) before disposal. The proposed treatments will comply with the 55 FR 22520 and WAC 173-303-140 treatment requirements. The specific processes to be used currently are being selected. Polychlorinated biphenyls will continue to be stored until treatment capacit $2^{\prime}$ is identified. Figure 3-7 depicts the Central Waste Complex treatmel:t and disposal processes.

\subsubsection{3-K Stored Waste}

The 303-K waste consisis of container-stored waste. Current plans are to move the waste to storage at the Central Waste Complex for treatment by the Waste Receiving and Processing Facility. The Central Waste Complex treatment $\mathrm{pl}$ ans are discussed in Section 3.4.10.

\subsection{WASTE MINIMIZATION}

Table 3-7 summarizes the waste minimization methods currently in place or planned for the 16 waste units addressed in this Plan. The table also shows schedules for implementation and the projected effectiveness of the method.

Future mixed-waste generation rates are dominated by the process condensate from the 242-A Evaporator (Table 3-1). In a typical year, over 20 times more process condensate is generated than all other wastestreams combined. However, the planned Effluent Treatment Facility will reduce, by greater than $99 \%$, the volume of process condensate designated as dangerous waste.

Next to $\mathrm{planned}$ treatment of the 242-A Evaporator process condensate stream, the most significant waste reduction is seen for double-shell tank waste. Evaporation of the dilute waste received into the double-shell tank reduces an annual average generation of 14,"100 cubic meters to approximately 3,000 cubic meters.

The waste currently stored at Central Waste Complex will be processed at the Waste Receiving and Processing Facility (described in Chapter 4.0 , Section 4.13) before disposal. This faciitty will minimize the amount of land disposal restricted waste by separating the dangerous constituents of the waste from the nondangerous constituents. 
In a typical year, waste minimization practices at the Hanford Site will prevent the volume by well over 100,000 cubic meters.

\subsection{VARIANCES, EXEMPTIONS, AND TIME EXTENSIONS}

Removal and treatment of the Hanford Site stored mixed waste to meet 1 and disposal restrictions requirements are summarized in Section 3.4 .

The national capacity variance for third third waste (55 FR 22520) and a compliance agreement (Ecology et al. 1989) for solvent list waste (40 CFR 268.30 ) and Cal ifornia list waste (40 CFR 268.32) allow storage of the mixed waste in the various Hanford Site storage units until treatment and disposal capacity is available and the waste can be treated and disposed.

If additional variances, exemptions, or extensions of time are required as a result of delays in the development of treatment, storage or disposal capacity, they will be applied for in accordance with the procedures detailed in the Tri-Party Agreement (Ecology et al. 1989).

The Tri-Party Agreement provides for extension of a schedule or a deadline when good cause exists for an extension. An extension is requested in writing and the Tri-Party Agreement requires that it be accompanied by the following information:

- Identification of the scheduled deliverable for which an extension is sought

- The good cause for the extension

- Identification of any related schedule affected by the extension.

Good cause for an extension may include the following:

- Force majeure

- A delay caused by another party's failure to meet a requirement of the Tri-Party Agreement

- A delay caused by good faith invocation of dispute resolution procedures or initiation of judicial action

- A delay resulting from an extension granted to a related schedule

- Any other event mutually agreed to as constituting good cause. 
DOE/RL-90-41

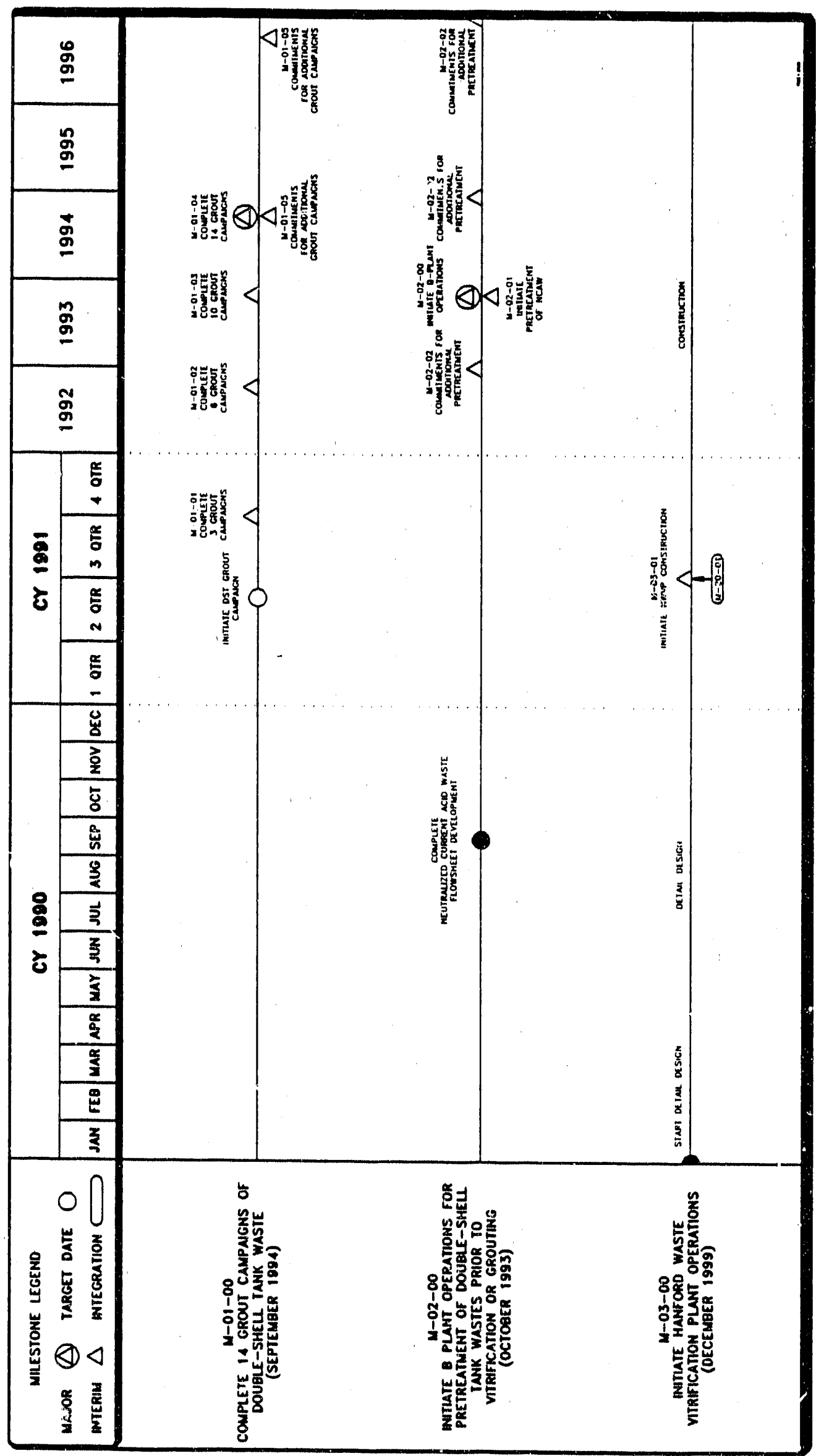

Figure 3-1. Permitting Schedules for Units Managing Land Disposal Restricted Wastes. (sheet 1 of 4 ) 


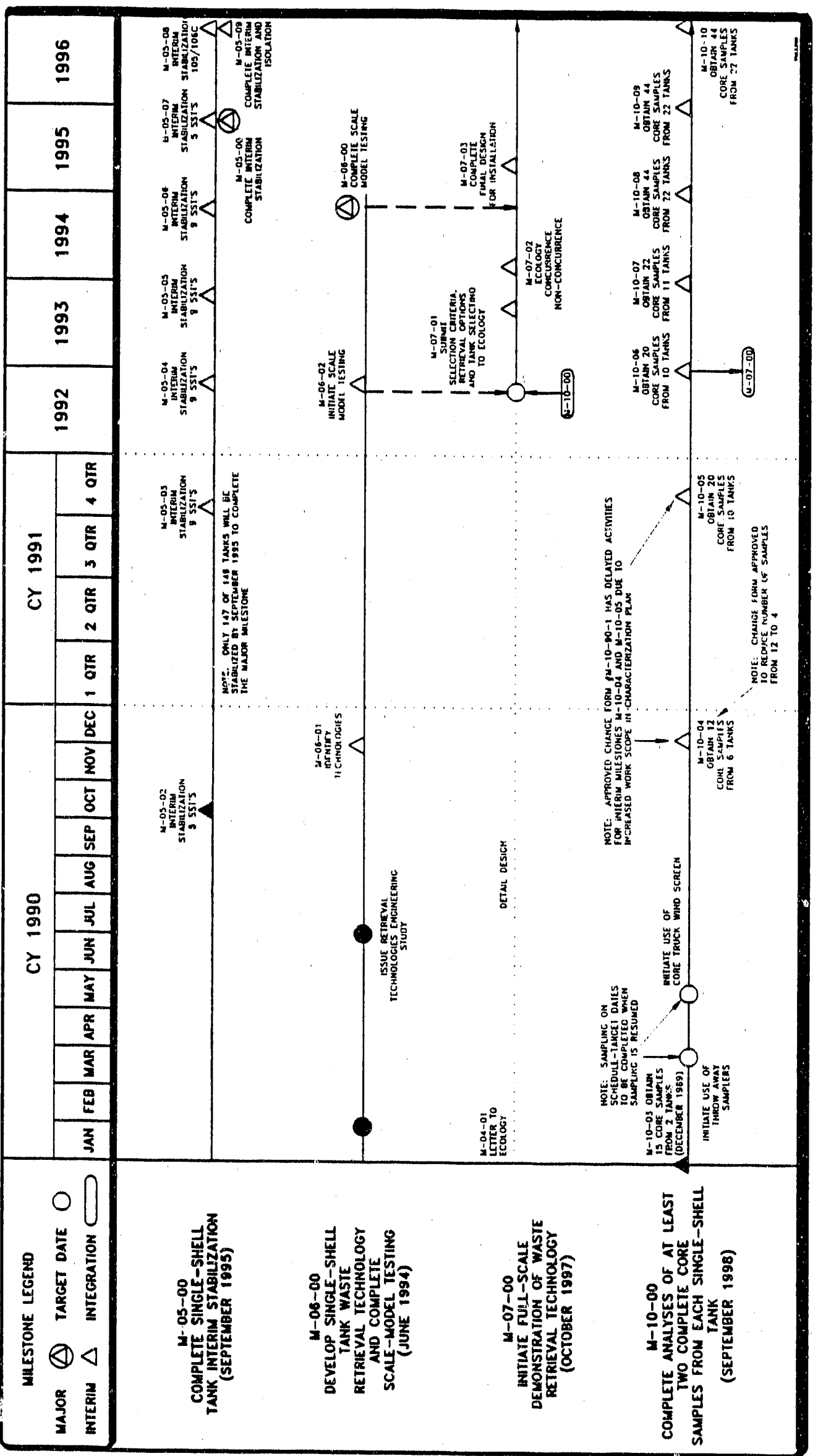

Figure 3-1. Permitting Schedules for Units Managing Land Disposal Restricted Wastes. (sheet 2 of 4 ) 
$\mathrm{DOE} / \mathrm{RL}-90-41$

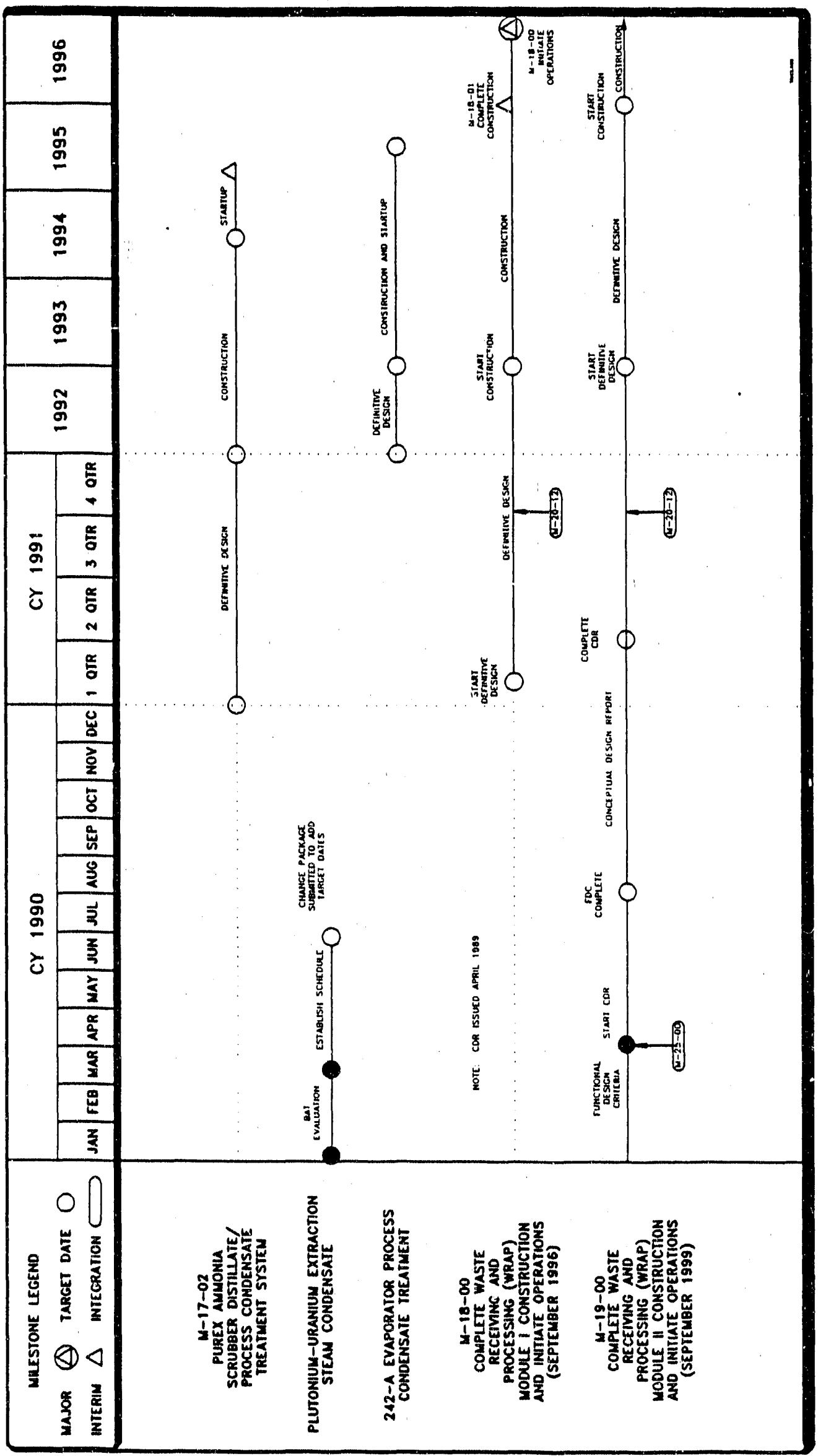

Figure 3-1. Permitting Schedules for Units Managing Land Disposal Restricted Wastes. (sheet 3 of 4 ) 


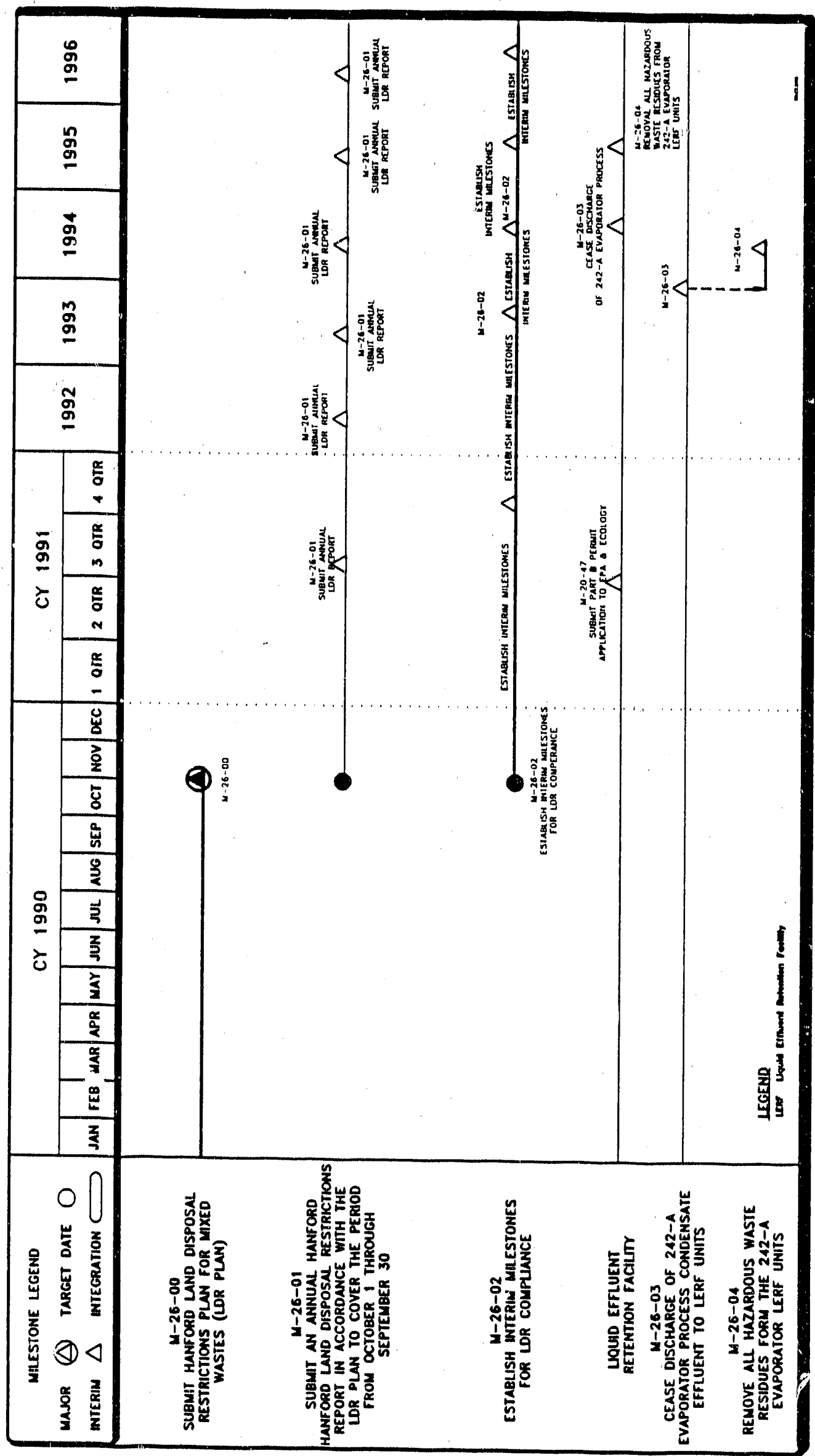

Figure 3-1. Permitting Schedules for Units Managing Land Disposal Restricted Wastes. (sheet 4 of 4 ) 


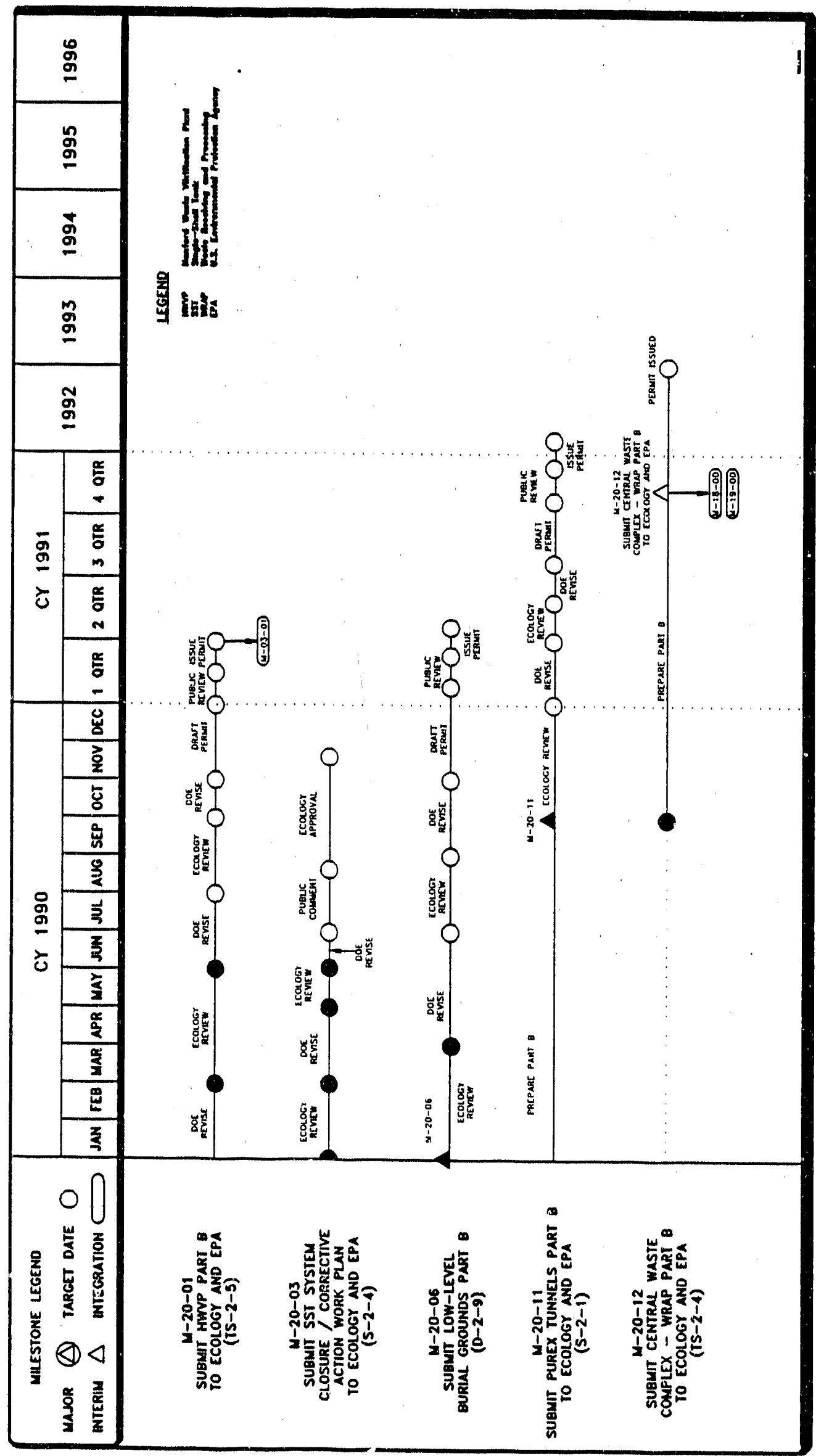

Figure 3-2. Operating Schedules for Units Managing Land Disposal Restricted Waste. (sheet 1 of 4 ) 
DOE/RL $-90-41$

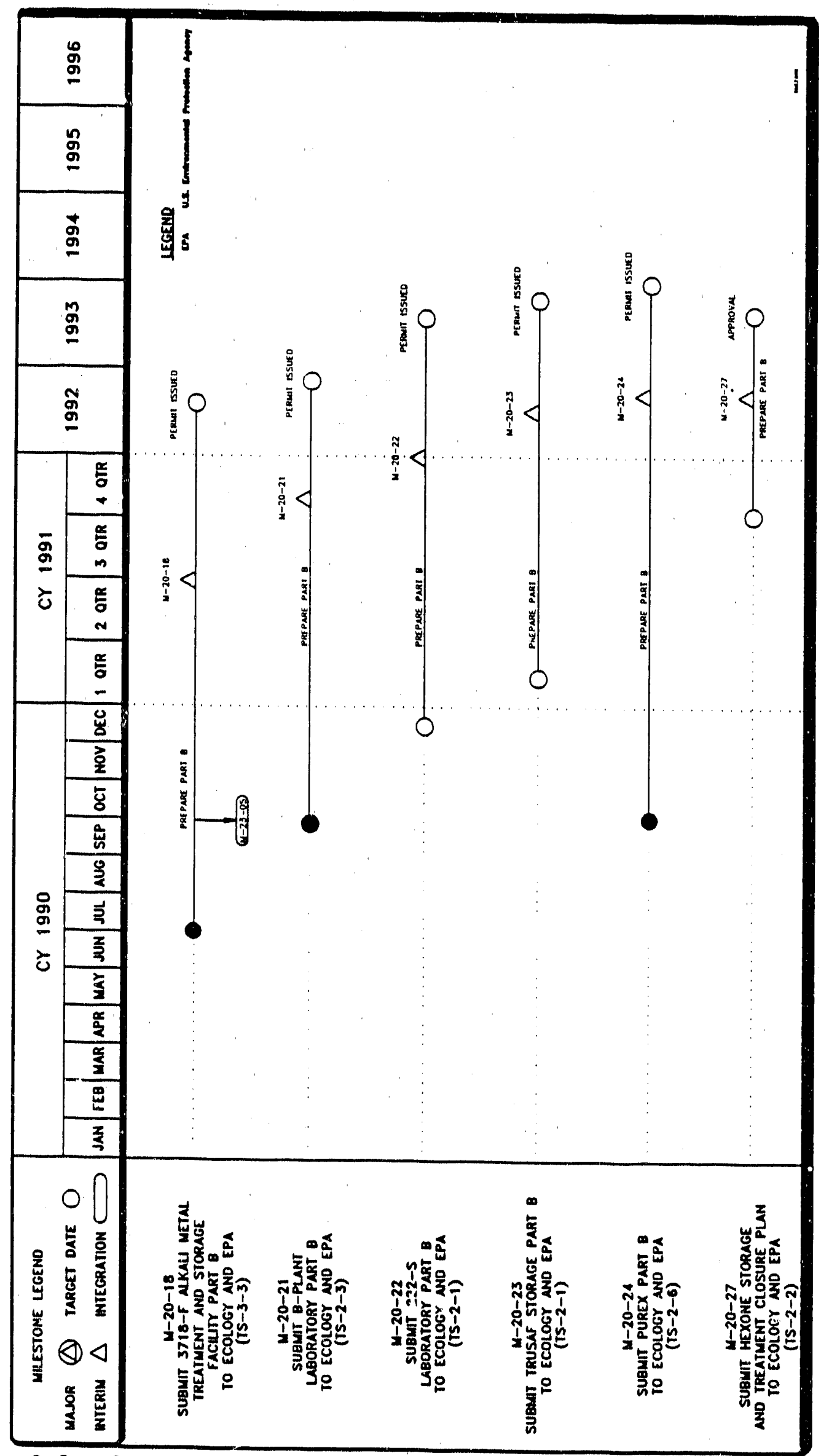

Figure 3-2. Operating Schedules for Units Managing Land Disposal Restricted Waste. (sheet 2 of 4 ) 
DOE/RL-90-41

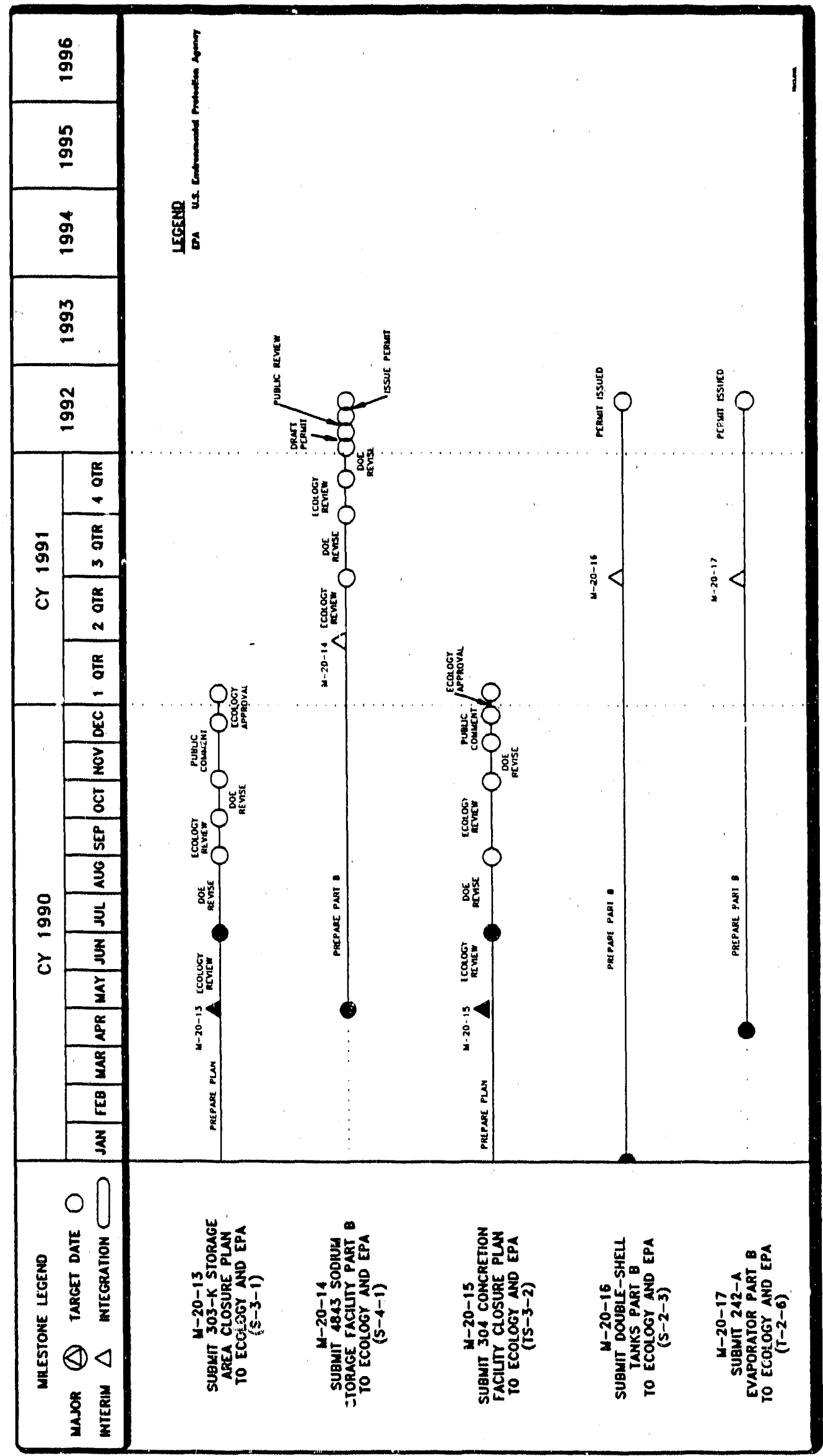

Figure 3-2. Operating Schedules for Units Managing Land Disposal Restricted Waste. (sheet 3 of 4 ) 


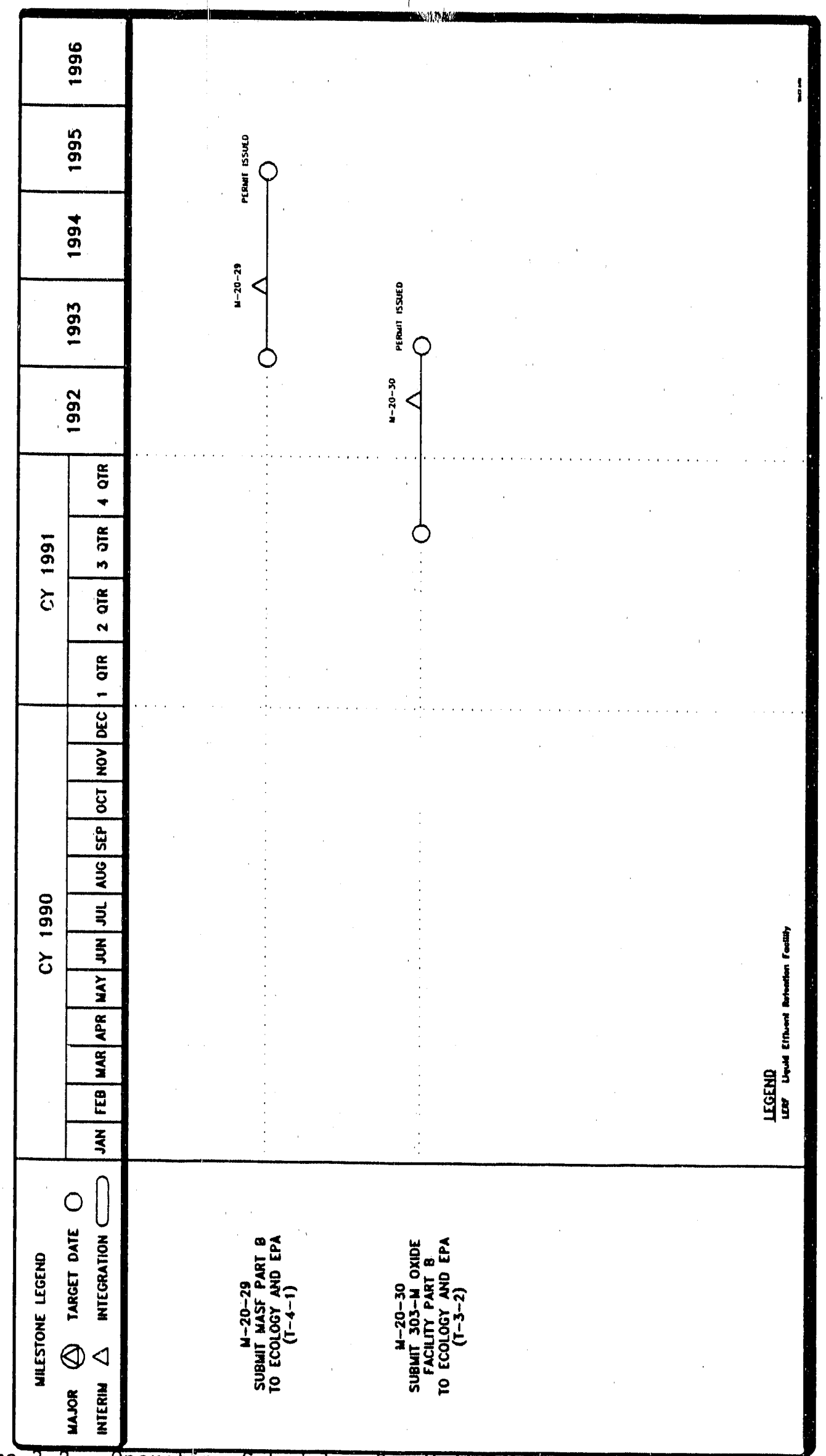

Figure 3-2. Operating Schedules for Units Managing Land Disposal Restricted Waste. (sheet 4 of 4 ) 


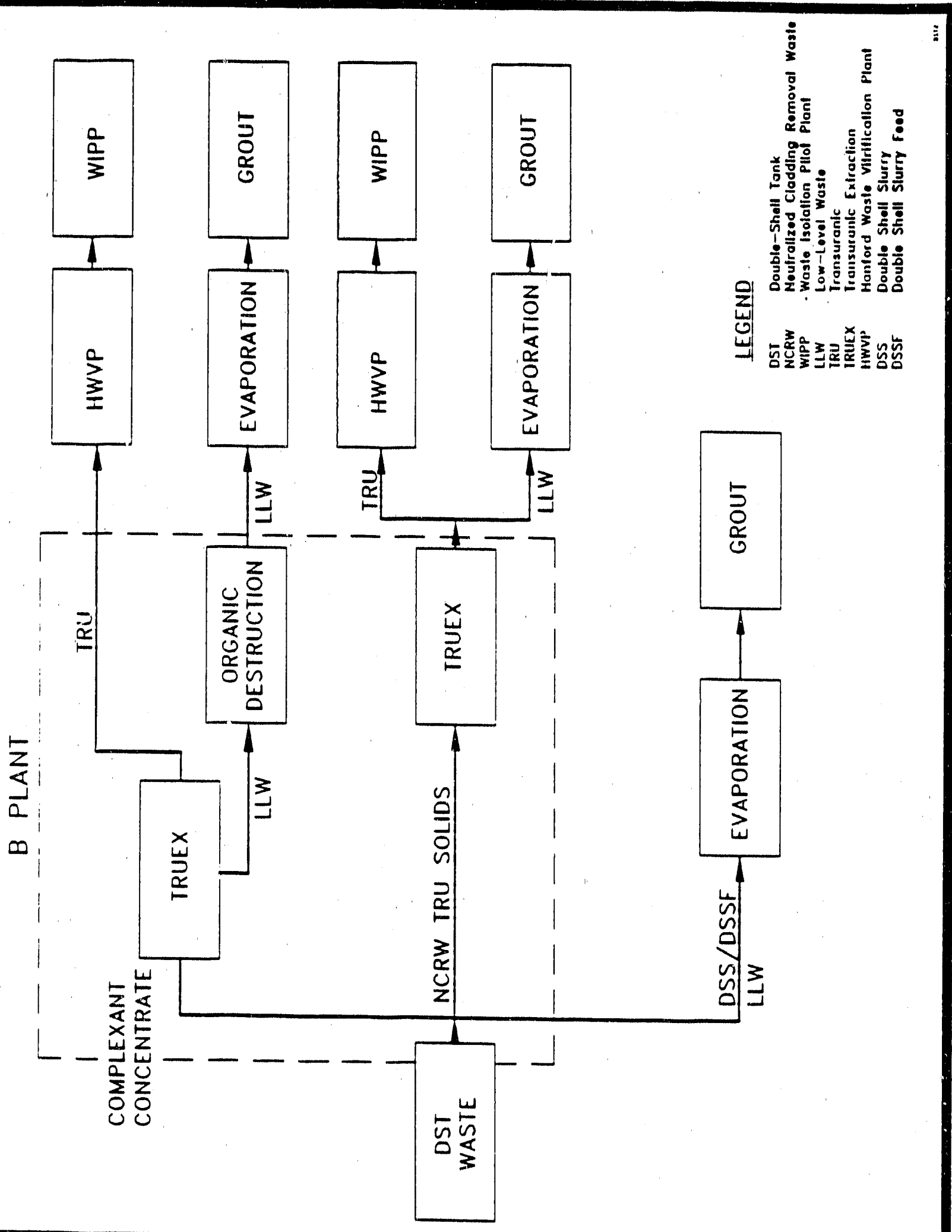

Figure 3-3. Double-Shell Tank Waste Treatment Flow Diagram F3-3 


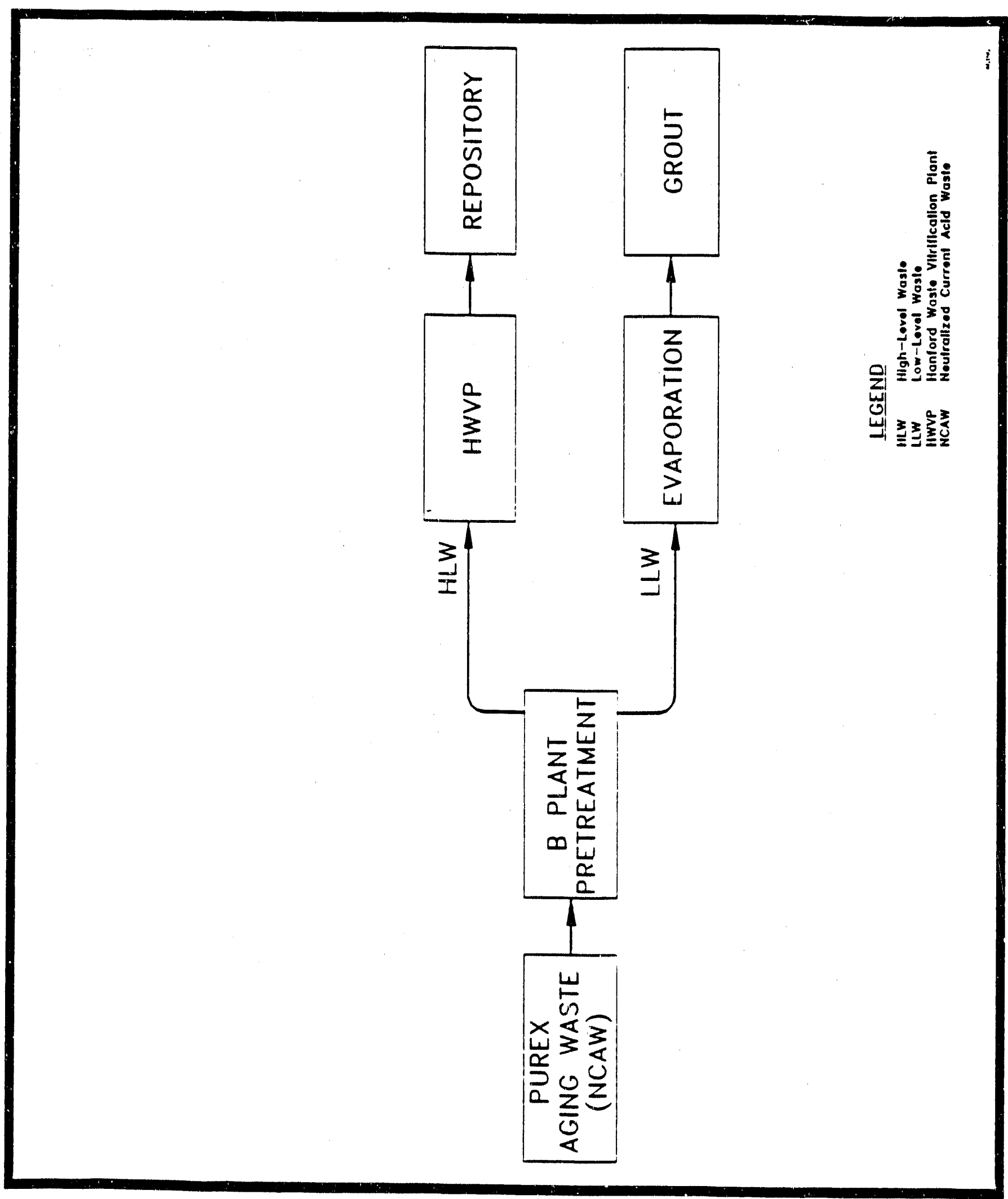

Figure 3-4. PUREX Aging Waste Treatment Flow Diagram

F3-4 


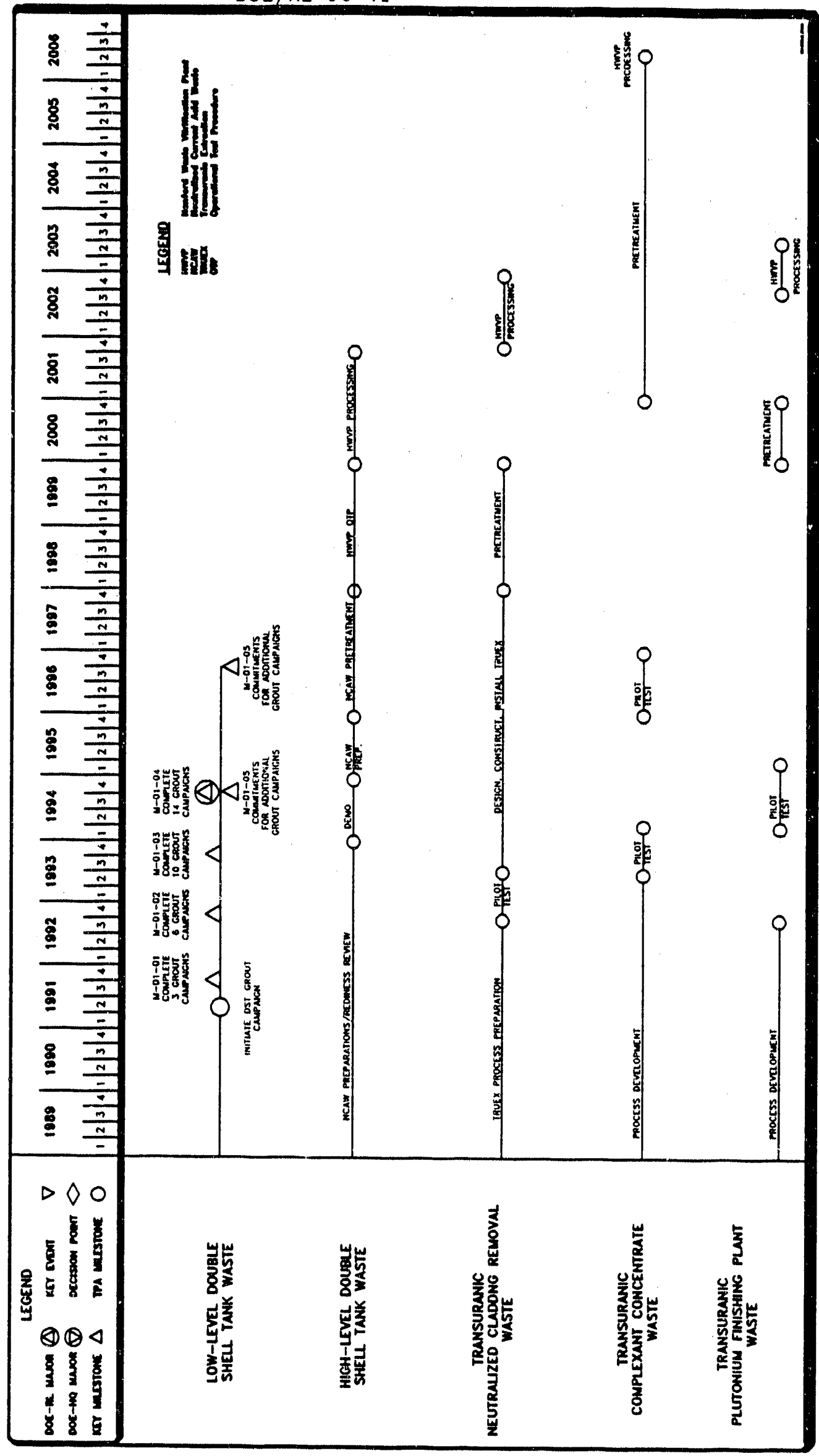

Figure 3-5. Double-She11 Tank Waste Treatment Schedule F3-5 


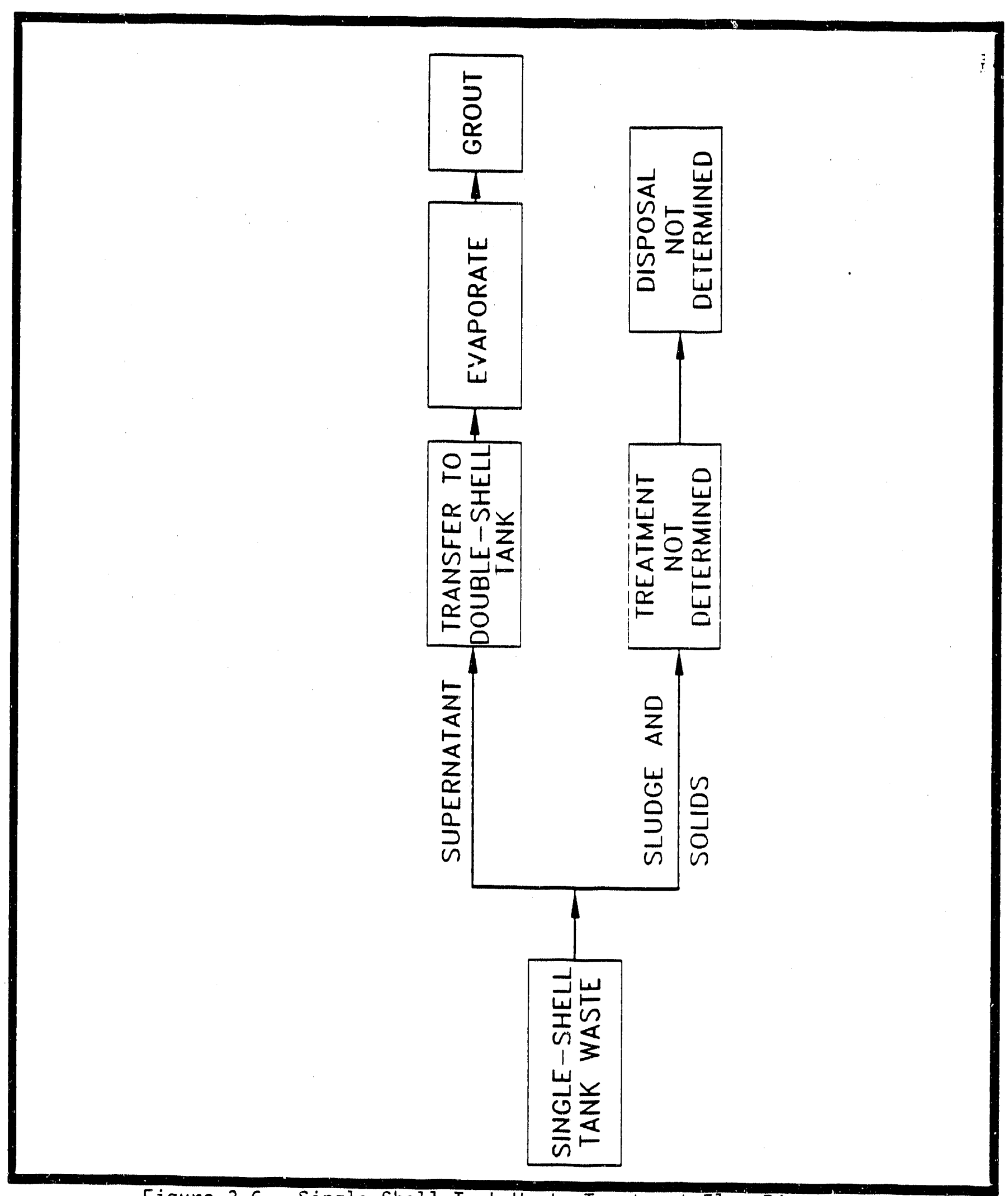

Figure 3-6. Single-Shell Tank Waste Treatment Flow Diagram

F3-6 


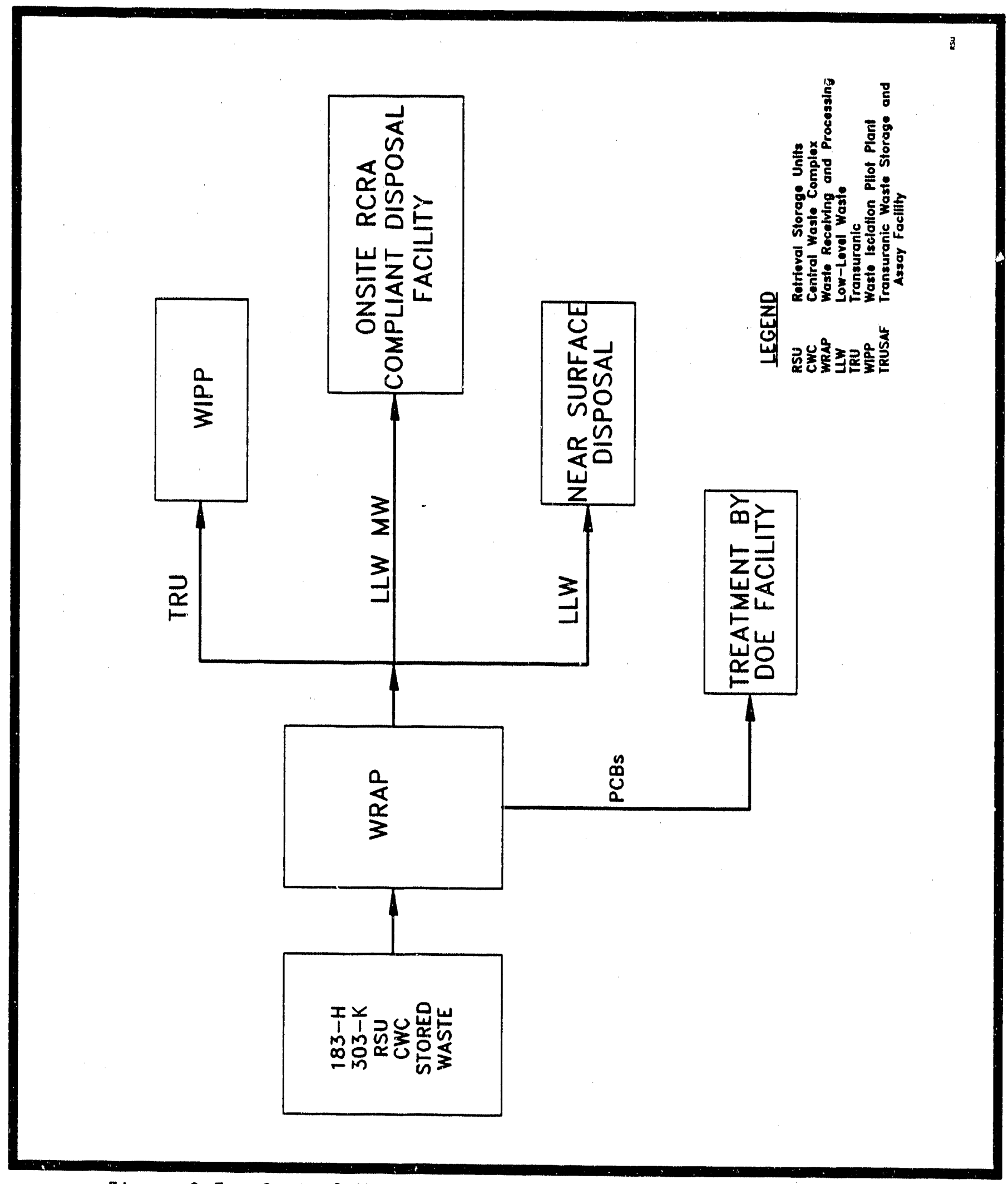

Figure 3-7. Central Waste Complex Stored Waste, Retrievably Stored Waste, 183-H Solar Bas in Waste and 303-K Waste Treatment Flow Diagram 


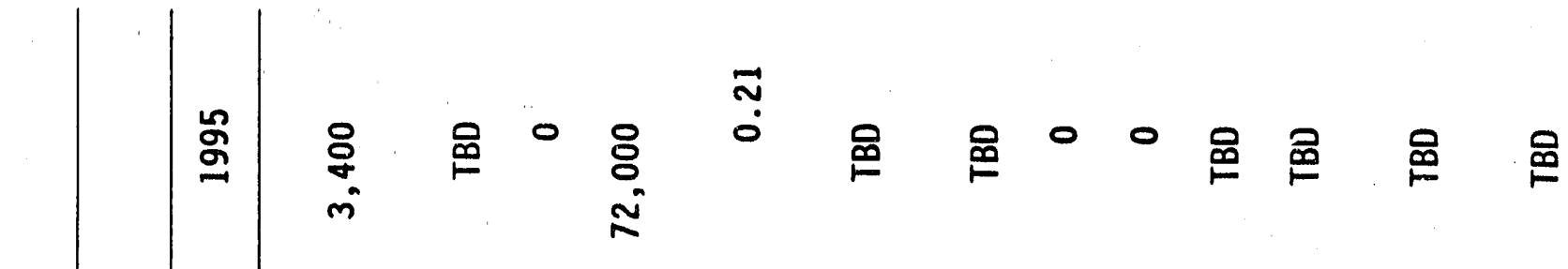

$$
\begin{aligned}
& 4
\end{aligned}
$$

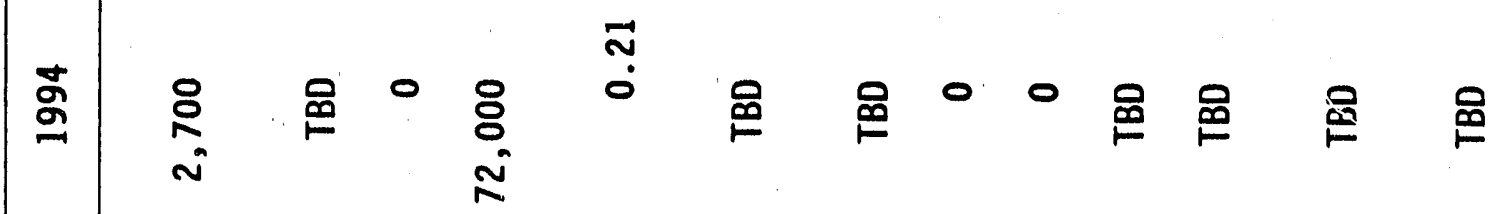

$$
\begin{aligned}
& \text { 岕 }
\end{aligned}
$$

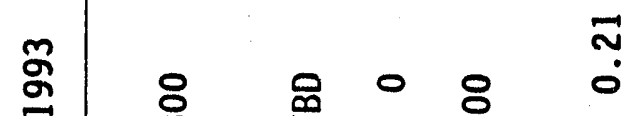

$$
\begin{aligned}
& \text { • } \\
& \text { m }
\end{aligned}
$$

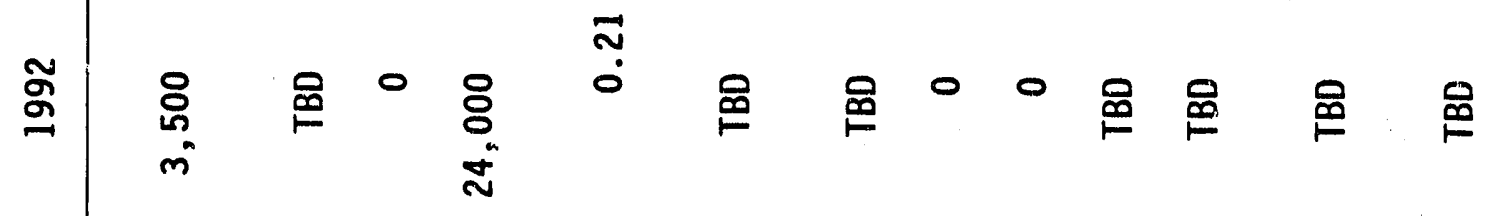

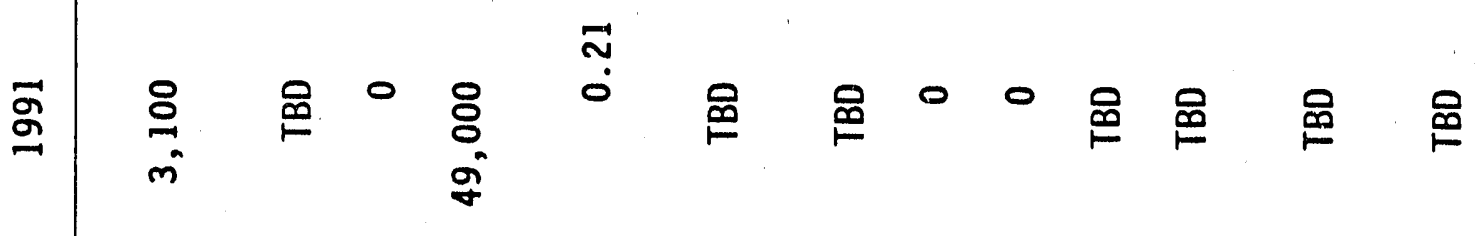

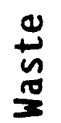

$$
\begin{aligned}
& \text { 突 } \\
& 4
\end{aligned}
$$

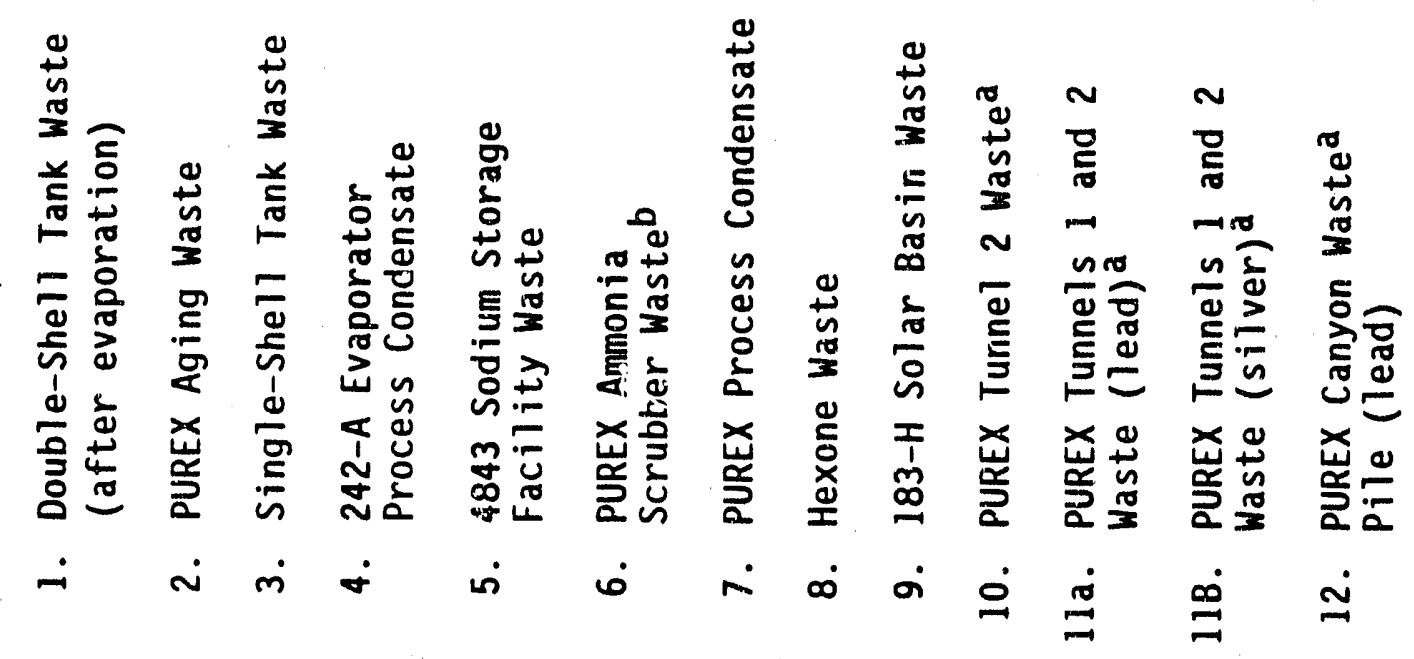


DOE/RL-90-41

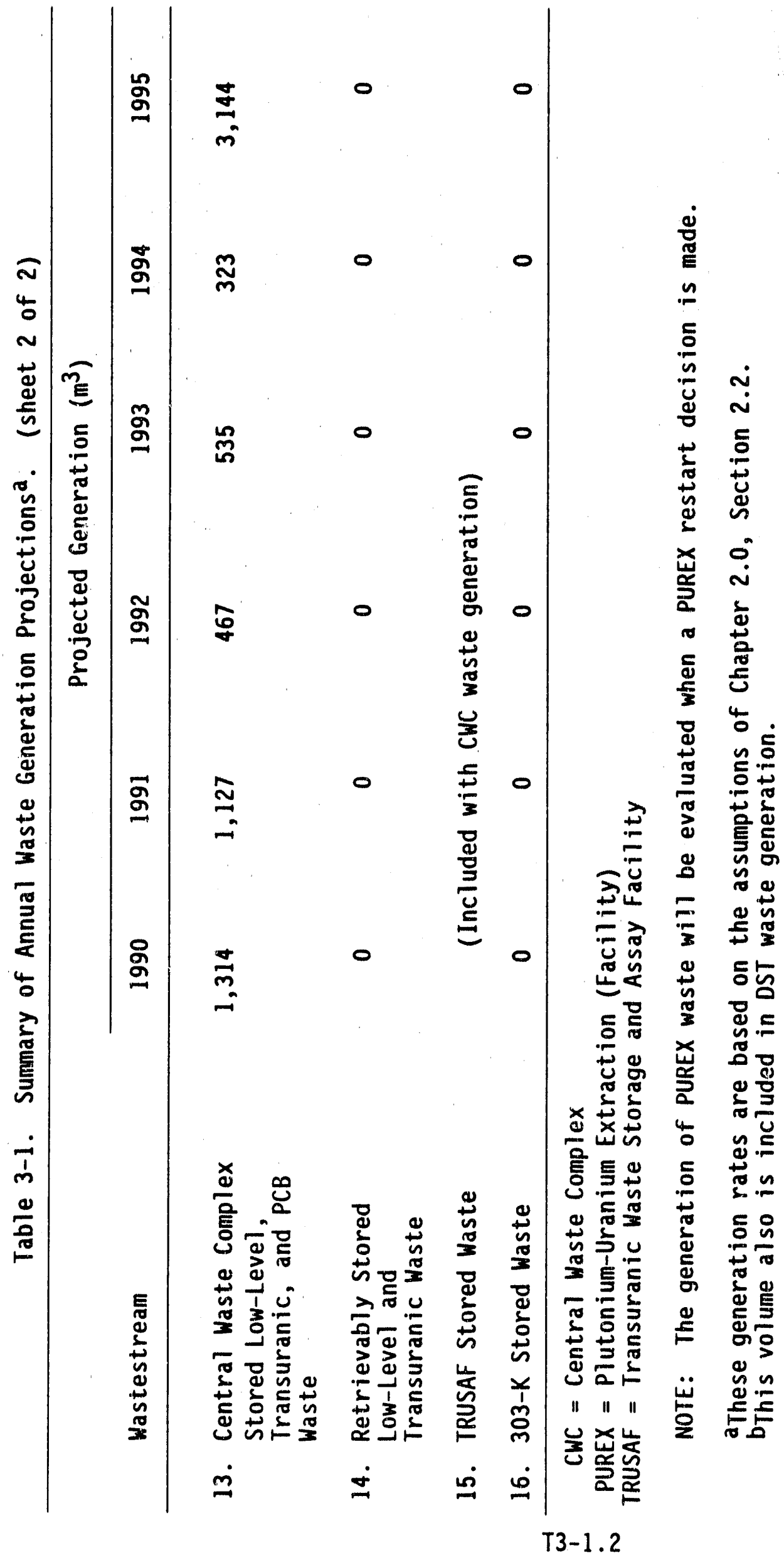


DOE/RL-90-41
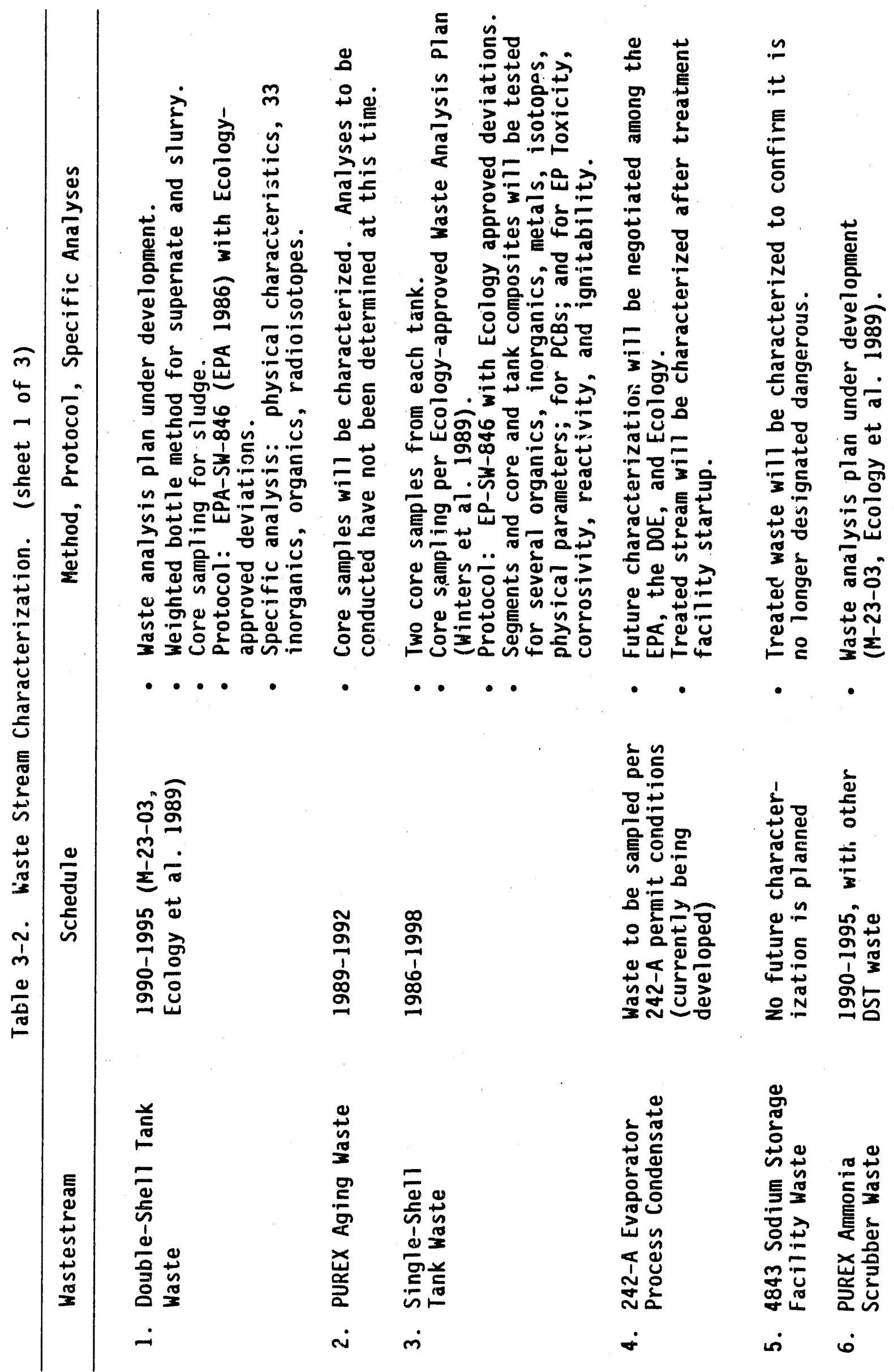

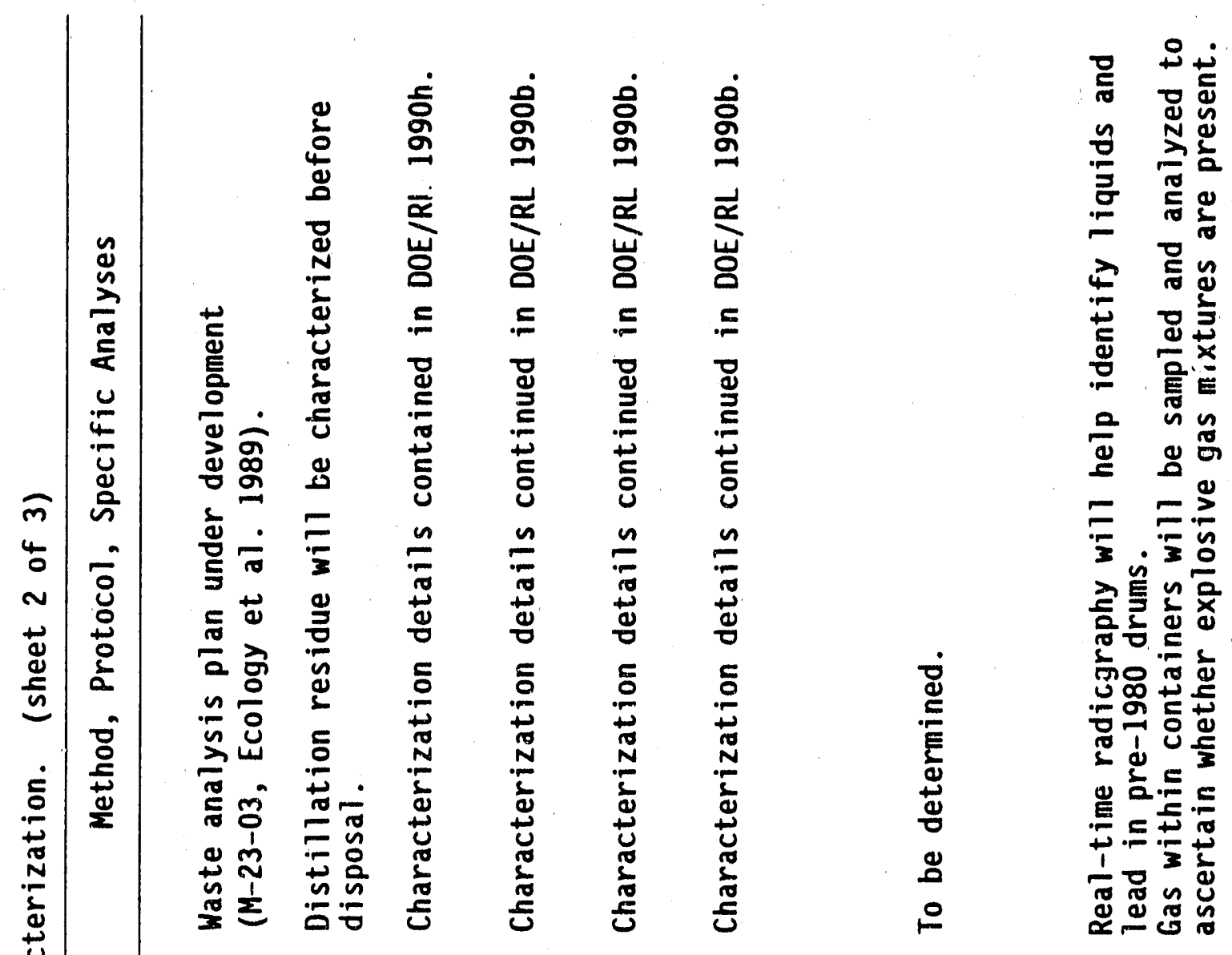

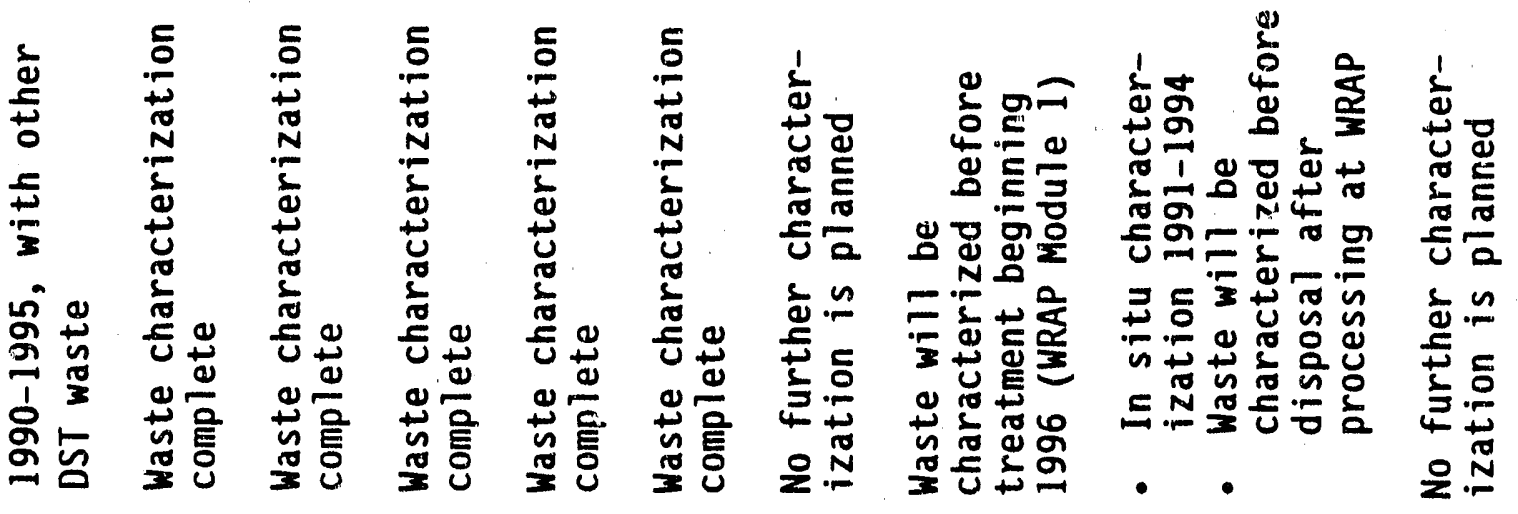

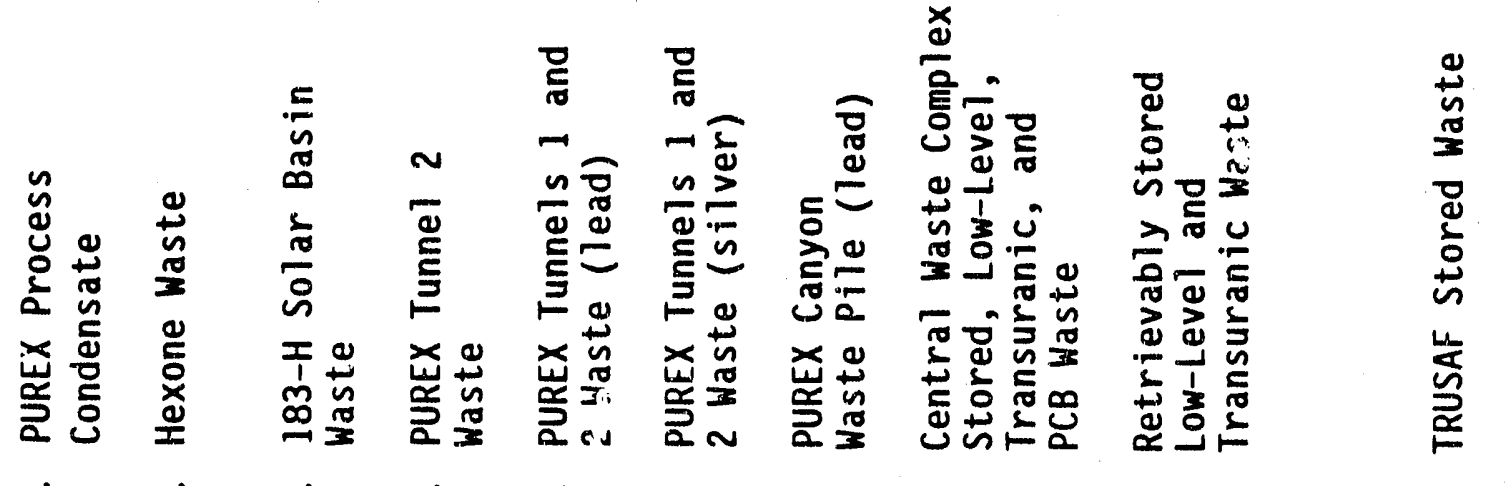

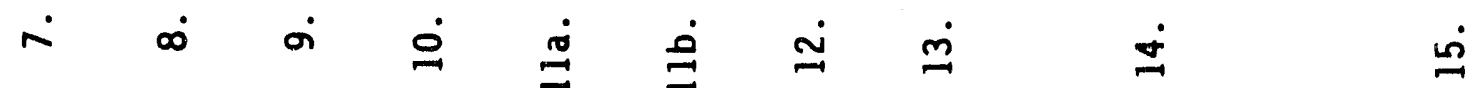


DOE/RL-90-41

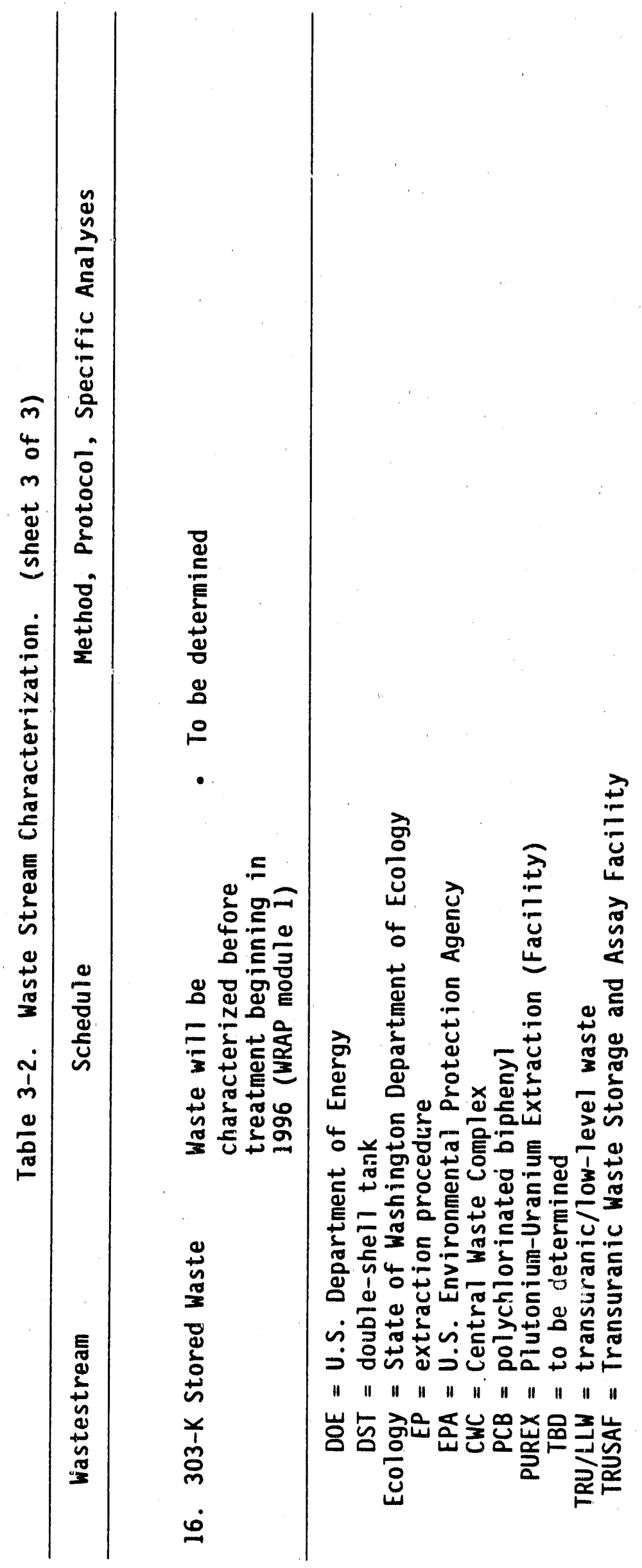

T3-2. 3 
Table 3-3. Hazardous Waste Designations of Plan Waste Streamsa. (sheet 1 of 4 )

\begin{tabular}{|c|c|}
\hline Waste Stream & Designated Waste Code(s) \\
\hline 1. Double-Shell Tank Waste & $\begin{array}{l}\text { D001 (ignitable)a,b } \\
\text { D002 (corrosive) } \\
\text { D004 (TCLP arsenic) } \\
0005 \text { (TCLP barium) } \\
\text { D006 (TCLP cadmium) } \\
\text { D007 (TCLP chromium) } \\
\text { D008 (TCLP lead) } \\
\text { D009 (TCLP mercury) } \\
\text { D010 (TCLP selenium) } \\
\text { D011 (TCLP silver) } \\
\text { F003 (acetone and hexone) } \\
\text { WCO1 (carcinogenic) } \\
\text { WCO2 (carcinogenig) } \\
\text { WPO1 (persistent) } \\
\text { WPO2 (persistent)b } \\
\text { WTO1 (toxic)b } \\
\text { WT02 (toxic)b }\end{array}$ \\
\hline 2. PUREX Aging Waste & $\begin{array}{l}\text { D001 (ignitable)a,b } \\
\text { D002 (corrosive) } \\
\text { D006 (TCLP cadmium) } \\
\text { D007 (TCLP chromium) } \\
\text { D008 (TCLP lead)b }\end{array}$ \\
\hline 3. Single-Shell Tank Waste & $\begin{array}{l}\text { D001 (ignitable) } \\
\text { D002 (corrosive) } \\
\text { D005 (TCLP barium) } \\
\text { D006 (TCLP cadmium) } \\
\text { D007 (TCLP chromium) } \\
\text { D008 (TCLP lead) } \\
\text { D009 (TCP mercury) } \\
\text { D010 (TCLP selenium) } \\
\text { D011 (TCLP silver) } \\
\text { D019 (TCLP carbon tetrachloride) } \\
\text { F003 (acetone and hexone) } \\
\text { WT01 (toxic) }\end{array}$ \\
\hline 4. 242-A Evaporator Process Condensate & $\begin{array}{l}\text { F003 (acetone and hexone) } \\
\text { F005 (methyl ethyl ketone) } \\
\text { WT02 (toxic) }\end{array}$ \\
\hline 5. 4843 Sodium Storage Facility & Do0s (reactive) \\
\hline 6. PUREX Ammonia Scrubber Waste & $\begin{array}{l}\text { D001 (ignitable) a,b } \\
\text { D002 (corrosive) } \\
\text { WT02 (toxic) }\end{array}$ \\
\hline
\end{tabular}


Table 3-3. Hazardous Waste Designation of
Plan Waste Streamsa. (sheet 2 of 4)

Table 3-3. Hazardous Waste Designation of
Plan Waste Streamsa. (sheet 2 of 4)

Wastestream

7. PUREX Process Condensate

8. Hexone Waste

9. 183-H Solar Basin Waste

10. PUREX Tunnel 2 Waste

11a. PUREX Tunnels 1 and 2 Waste (1ead)

11b. PUREX Tunnels 1 and 2 Waste (silver)

12. PUREX Canyon Waste Pile

13. Central Waste Comolex Stored, Low-Leve1, Transuranic, and PCB Waste
Designated Waste Code(s)

D002 (corrosive)

WTO1 (toxic)

F003 (hexone)

WT02 (toxic)

D001 (!nitable)

D007 (icLP chromium)

P029 (copper cyanides)

P030 (soluble cyanide salts)

P098 (potassium cyanide)

P106 (sodium cyanide)

P120 (vanadium pentoxide)

U123 (formic acid)

WTO1 (toxic)

WT02 (toxic)

D009 (TCLP mercury)

WTO1 (toxic)

D008 (TCLP lead)

WT01 (toxic)

D001 (ignitable)

D011 (TCLP silver)

WT01 (toxic)

D008 (TCLP lead)

WTO1 (toxic)

Do01 (ignitable) a,b

D002 (corrosive)

D003 (reactive)

D004 (TCLP arsenic)

D005 (TCLP barium)

D006 (TCLP cadmium)

D007 (TCLP chromium)

D008 (TCLP lead)

D009 (TCLP mercury)

D010 (TCLP selentum)

D011 (TCLP silver)

D012 (TCLP Endrin)

F001 (spent halogenated degreasing solvents)

F002 (spent halogenated solvents)

F003 (acetone) 
Table 3-3. Hazardous Waste Designations of Plan Waste Streams ${ }^{a}$. (sheet 3 of 4 )

Wastestream

13. Central Waste Complex Stored, Low-Leval, Transuranic, and PCB Waste (continued)
14. Retrievably Stored Low-Leve1, Transuranic, and PCB Waste
Designated Waste Code(s)

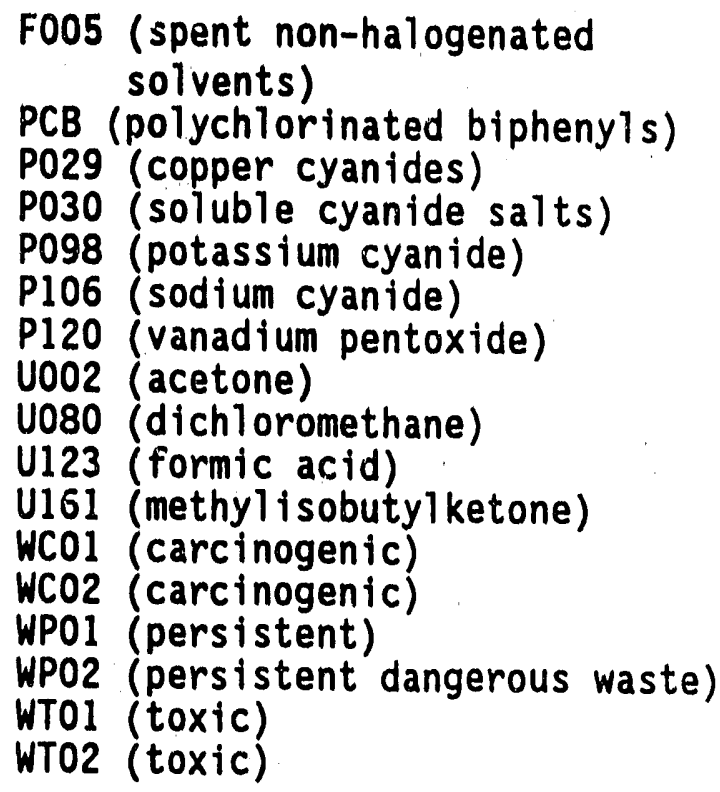
solvents)

PCB (polychlorinated biphenyls)

P029 (copper cyanides)

P030 (soluble cyanide salts)

P098 (potassium cyanide)

P106 (sodium cyanide)

P120 (vanadium pentoxide)

U002 (acetone)

U080 (dichloromethane)

U123 (formic acid)

U161 (methyl isobutylketone)

WCO1 (carcinogenic)

WCO2 (carcinogenic)

WPO1 (persistent)

WP02 (persistent dangerous waste)

WTO1 (toxic)

WTO2 (toxic)

D001 (ignitable) $a, b$
D002 (corrosive)
D003 (reactive)
D005 (TCLP barium)
D006 (TCLP cadmium)
D007 (TCLP chromium)
D008 (TCLP lead)
D009 (TCLP mercury)
D011 (TCLP silver)
F001 (spent halogenated
F002 (spent halogenated
F003 (acetone)
F005 (spent non-halogenated
Solvents)
WO01 (carcinogenic)
WP01 (persistent)
WT01 (toxic)


Table 3-3. Hazardous Waste Designations of Plan Waste Streams ${ }^{a}$. (sheet 4 of 4 )

\begin{tabular}{|c|c|}
\hline Wastestream & Designated Waste Code(s) \\
\hline 15. TRUSAF Stored Waste & $\begin{array}{l}\text { D002 (corrosive) } \\
\text { D005 (TCLP barium) } \\
\text { D006 (TCLP cadmium) } \\
\text { D007 (TCLP chromium) } \\
\text { D008 (TCLP lead) } \\
\text { D009 (TCLP mercury) } \\
\text { WC01 (carcinogenic) } \\
\text { WC02 (carcinogenic) } \\
\text { WP01 (persistent) } \\
\text { WT01 (toxic) }\end{array}$ \\
\hline 16. $303-K$ stored waste & $\begin{array}{l}\text { D001 (ignitable) } \\
\text { D002 (corrosive) } \\
\text { D004 (TCLP arsenic) } \\
\text { D005 (TCLP barium) } \\
\text { D006 (TCLP cadmium) } \\
\text { D007 (TCLP chromium) } \\
\text { D008 (TCLP lead) } \\
\text { D009 (TCLP mercury) } \\
\text { D011 (TCLP silver) } \\
\text { F001 (spent halogenated } \\
\text { degreasing solvents) } \\
\text { F003 (spent non-halogenated } \\
\text { solvents) } \\
\text { WC01 (carcinogenic) } \\
\text { WP01 (persistent) } \\
\text { WP02 (persistent) } \\
\text { WT01 (toxic) } \\
\text { WT02 (toxic) }\end{array}$ \\
\hline
\end{tabular}

$$
\begin{aligned}
\text { CWC } & =\text { Central Waste Complex } \\
\text { PUREX } & =\text { Plutonium-Uranium Extraction (Facility) } \\
\text { TCLP } & =\text { toxic characteristic leach procedure } \\
\text { TRUSAF } & =\text { Transuranic Waste Storage and Assay Facility }
\end{aligned}
$$

afurther information is given in Section 3.2. been tested.

besignation is based on process knowledge; waste has not 
DOE/RL-90-41

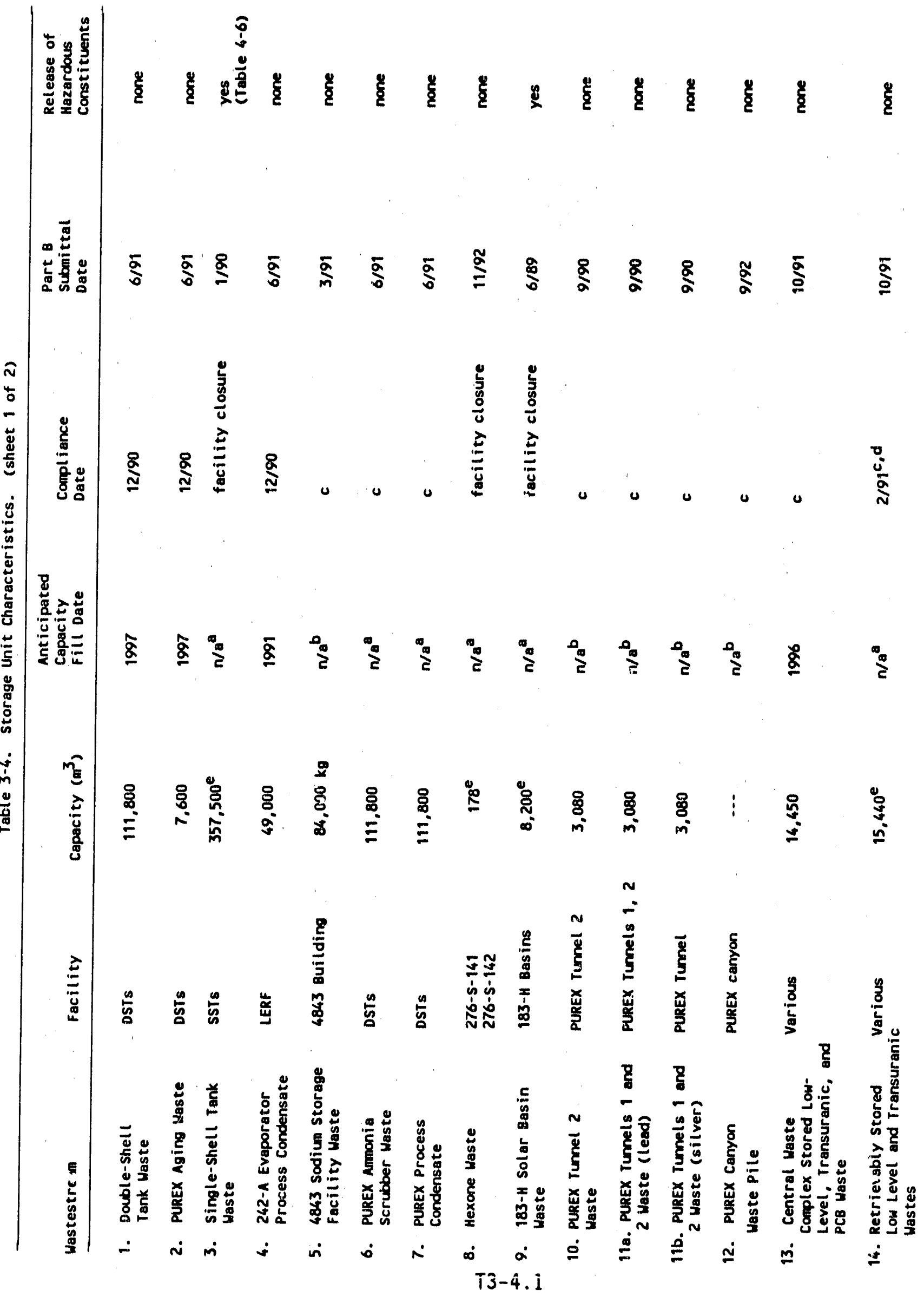


DOE/RL-90-41

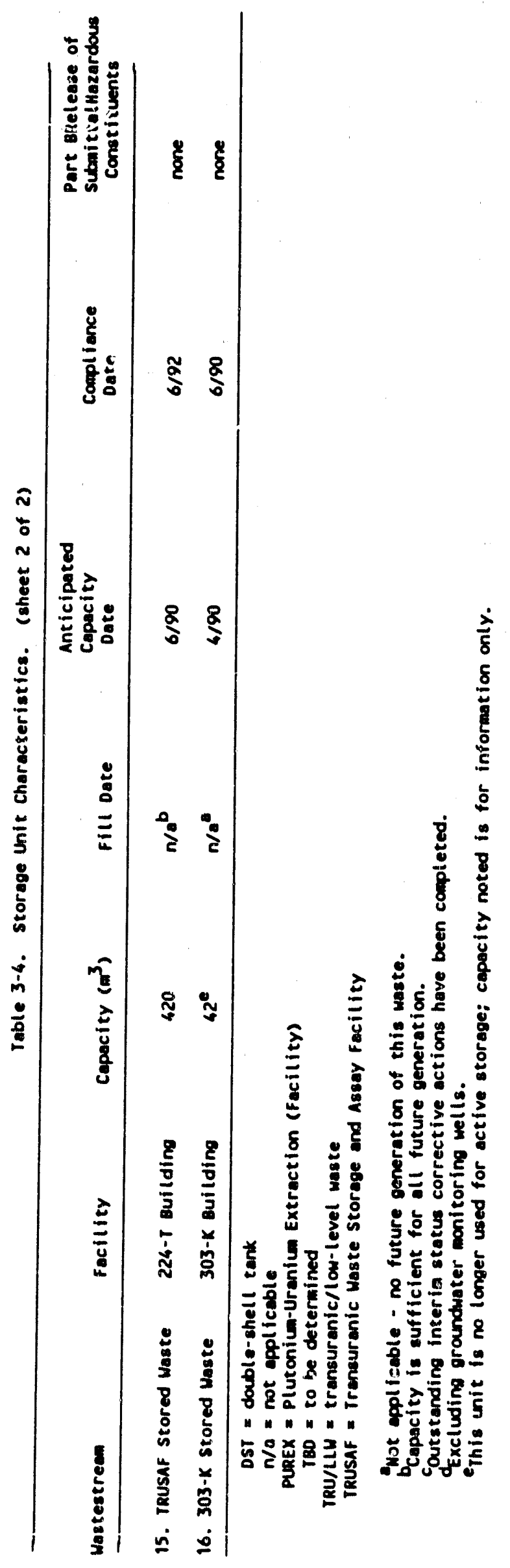

$T 3-4.2$ 
DOE/RL-90-41

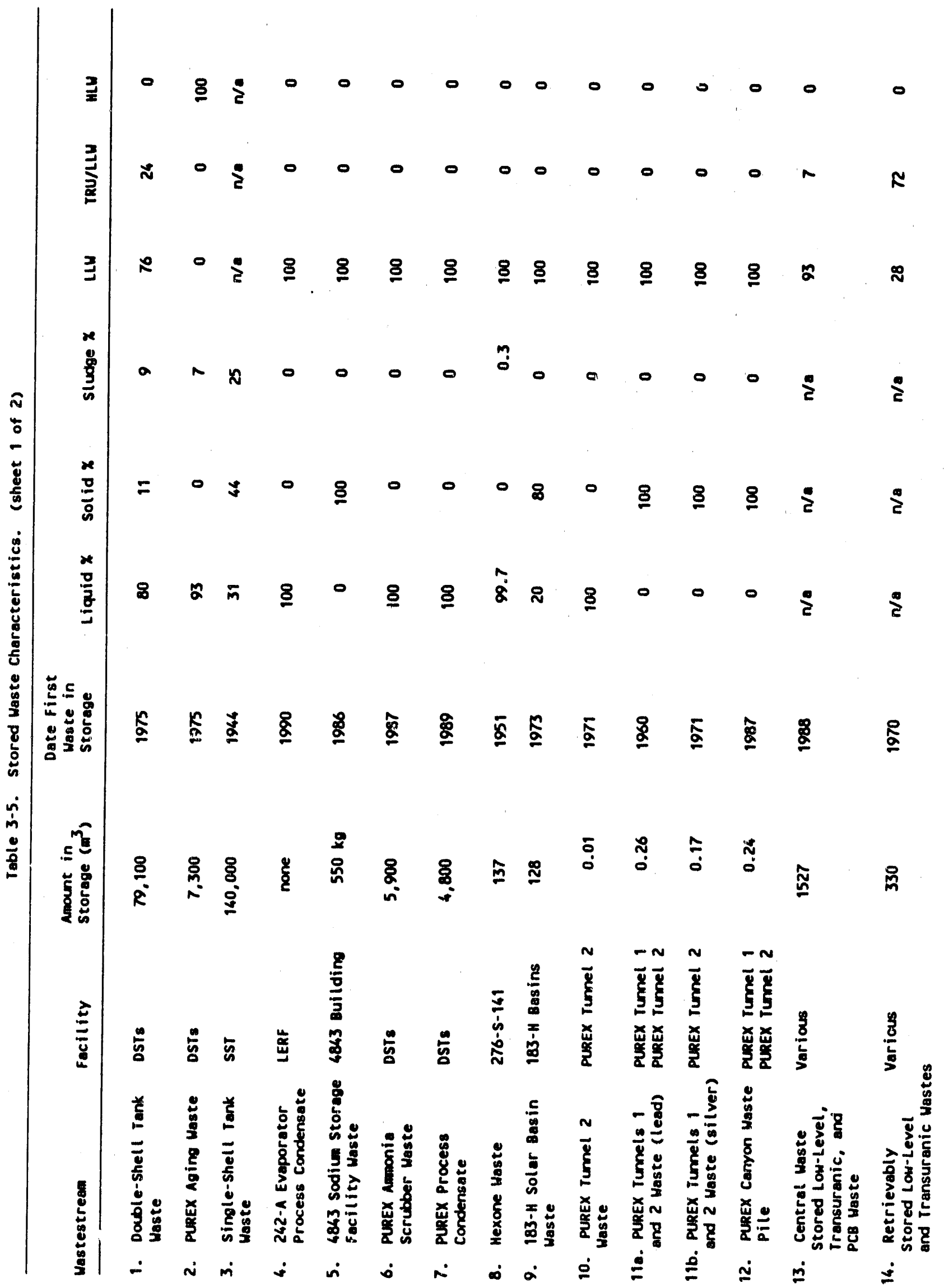


D0E/RL-90-41

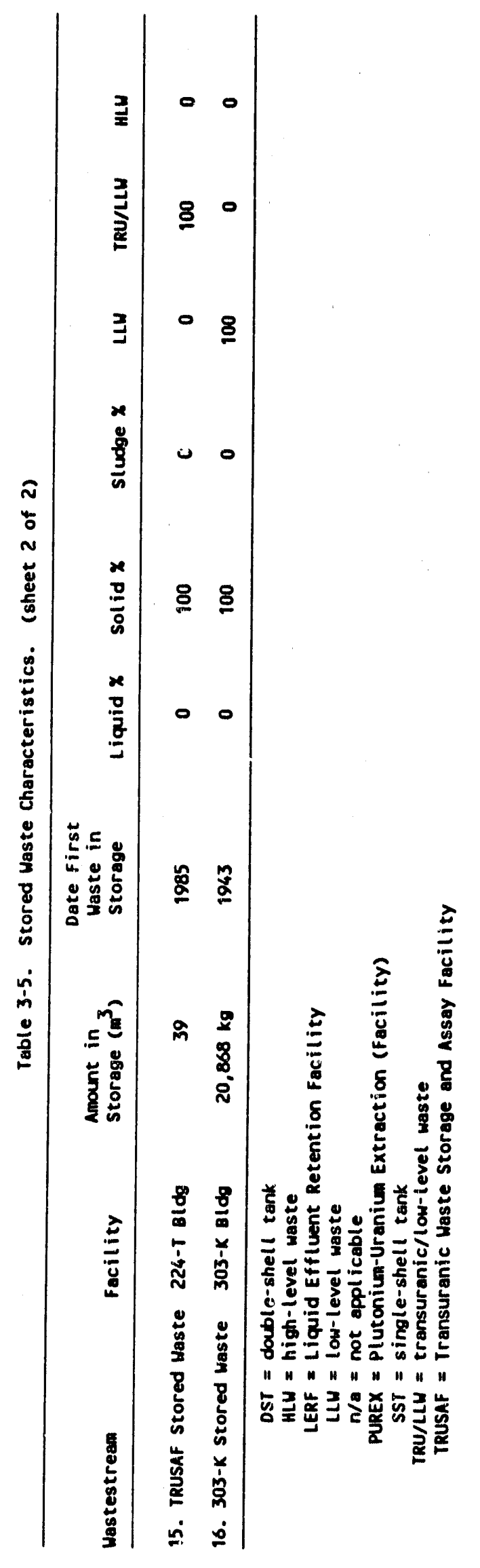




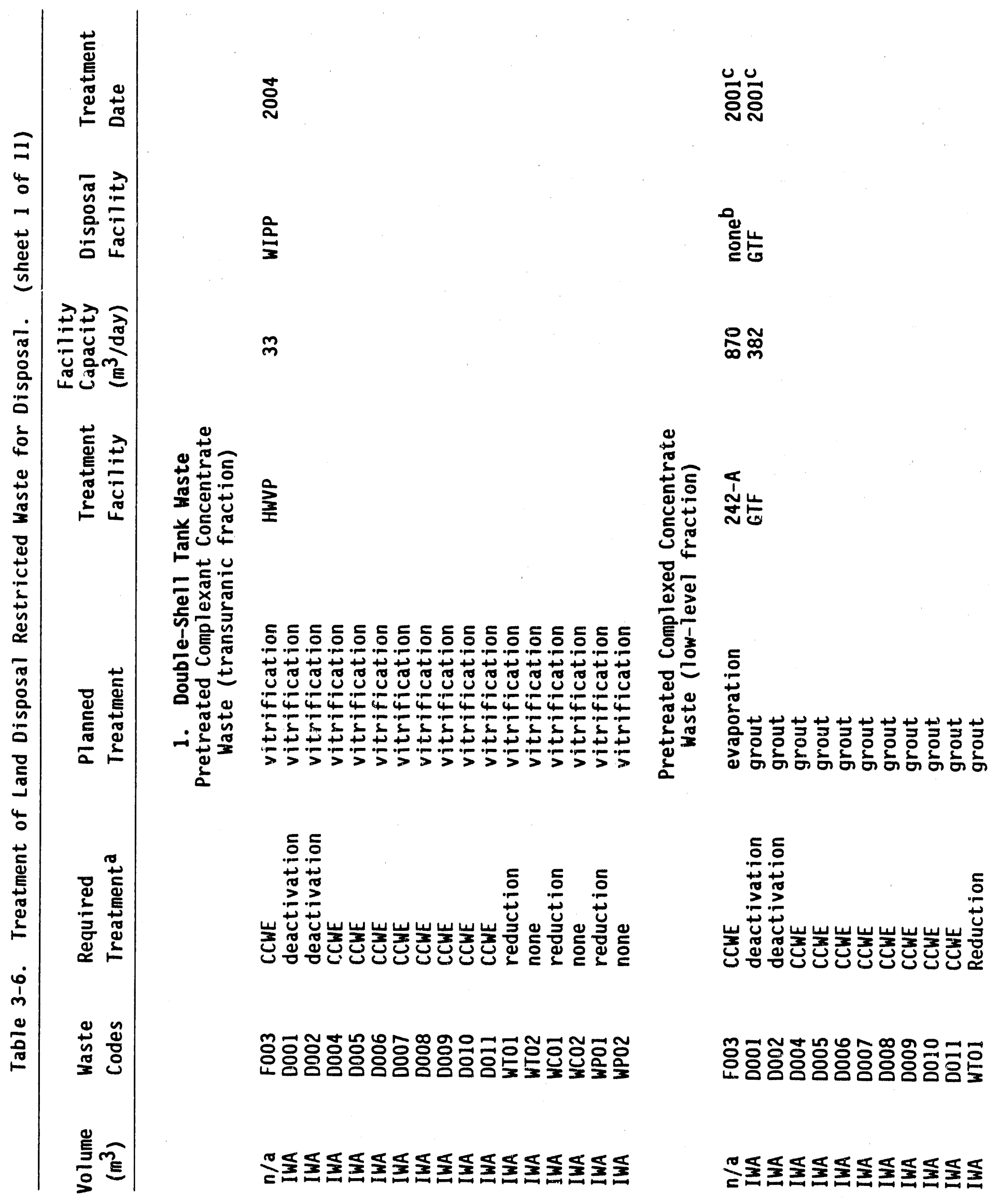




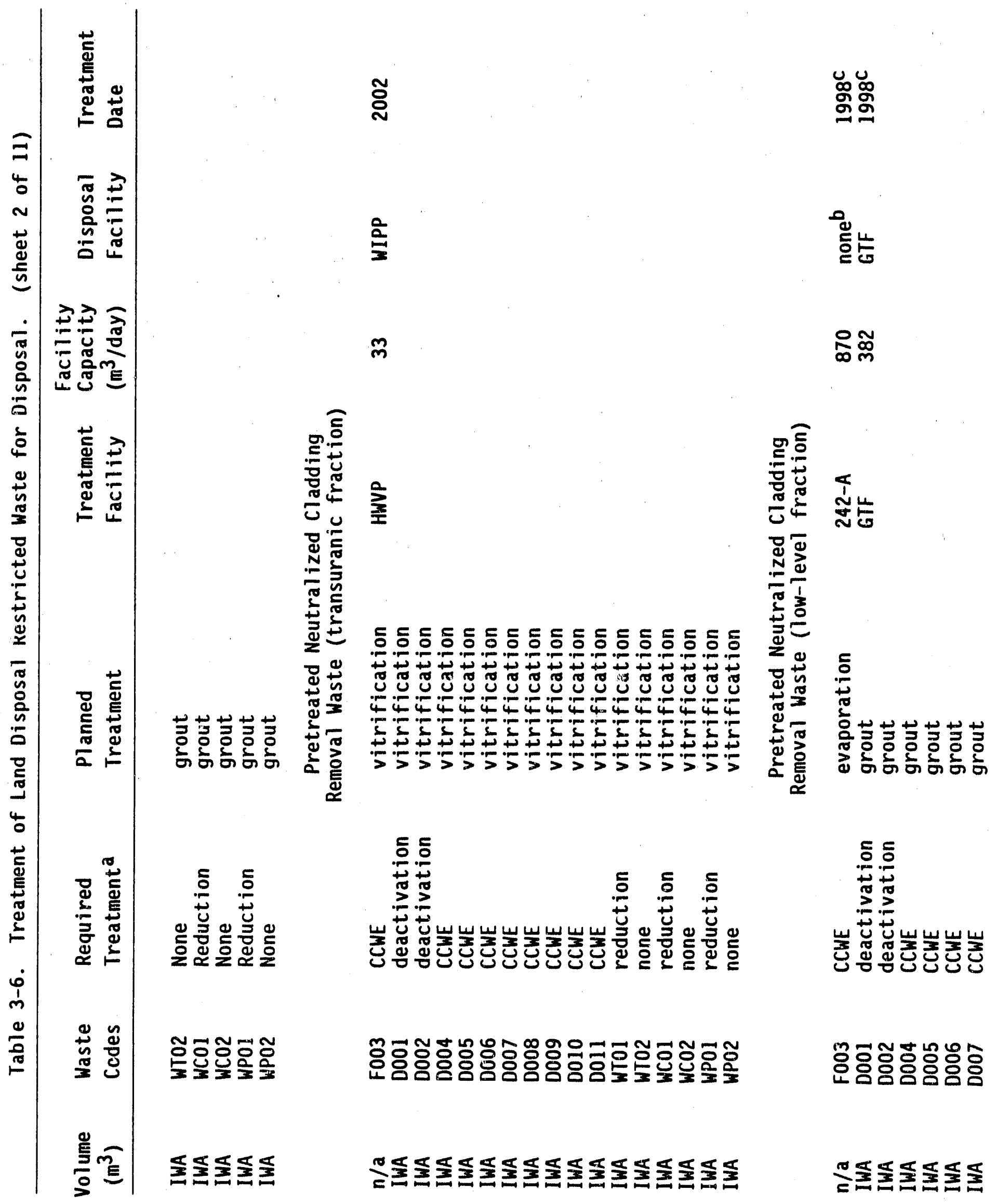


DOE/RL-90-41

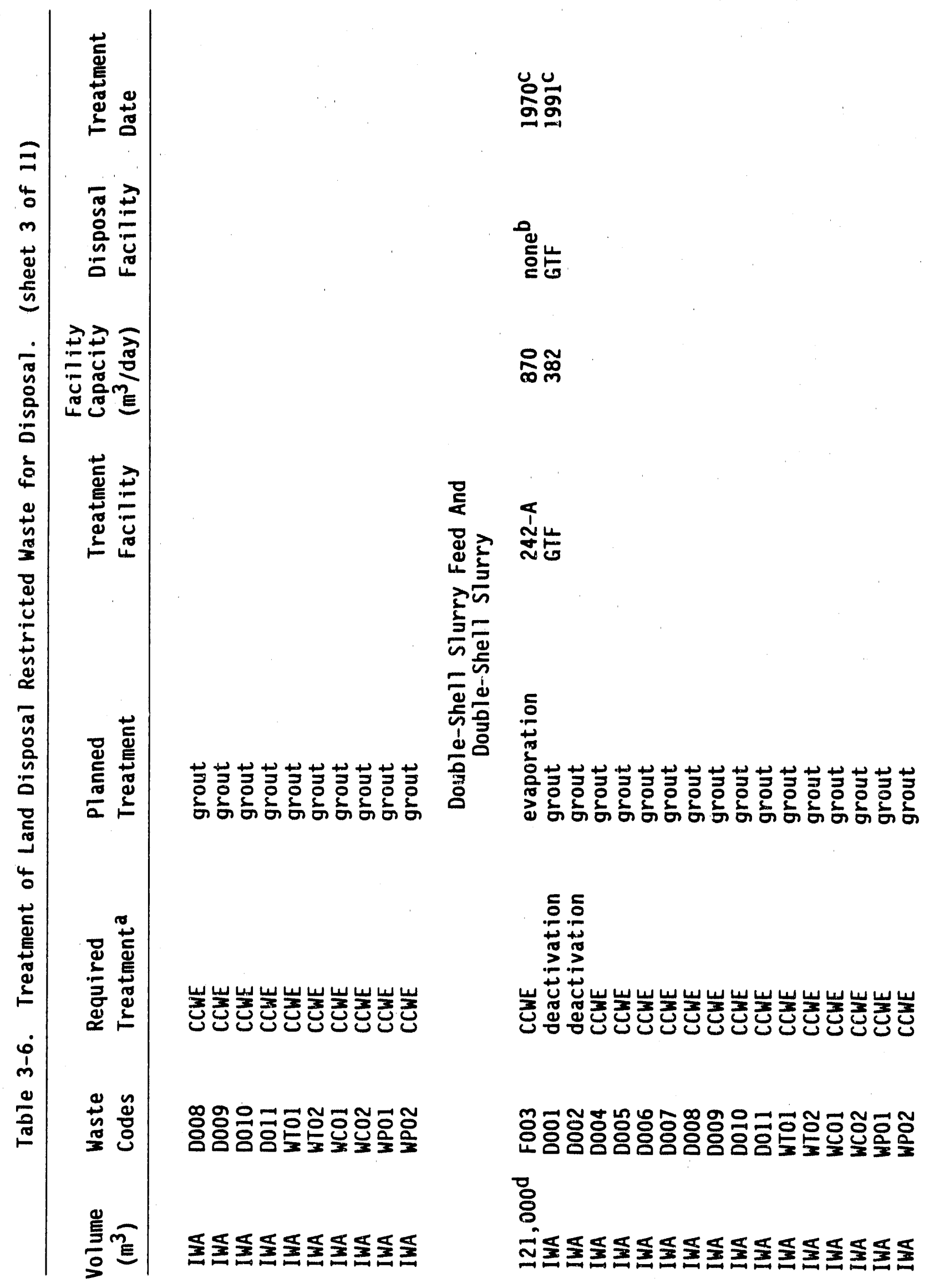




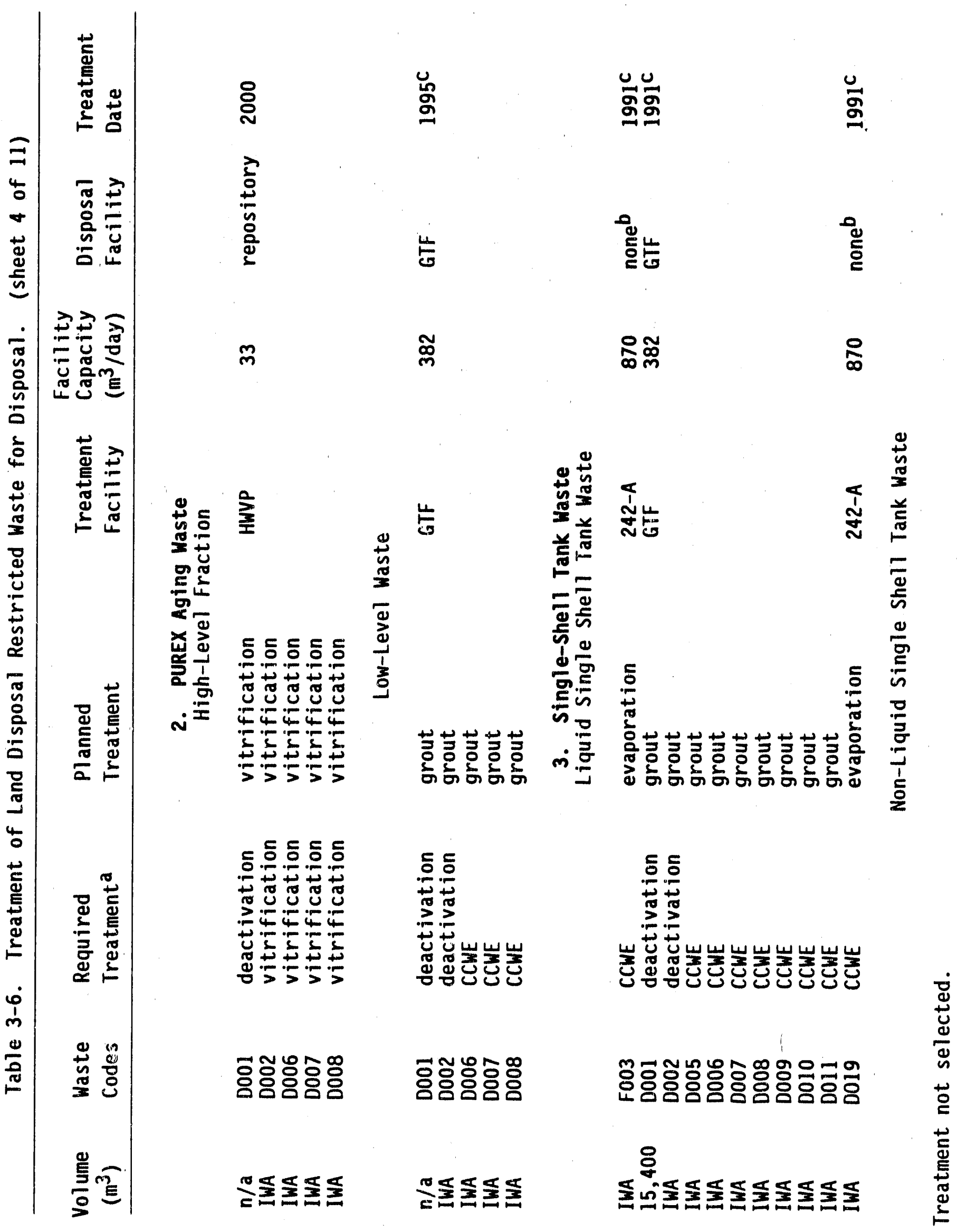


DOE/RL-90-41
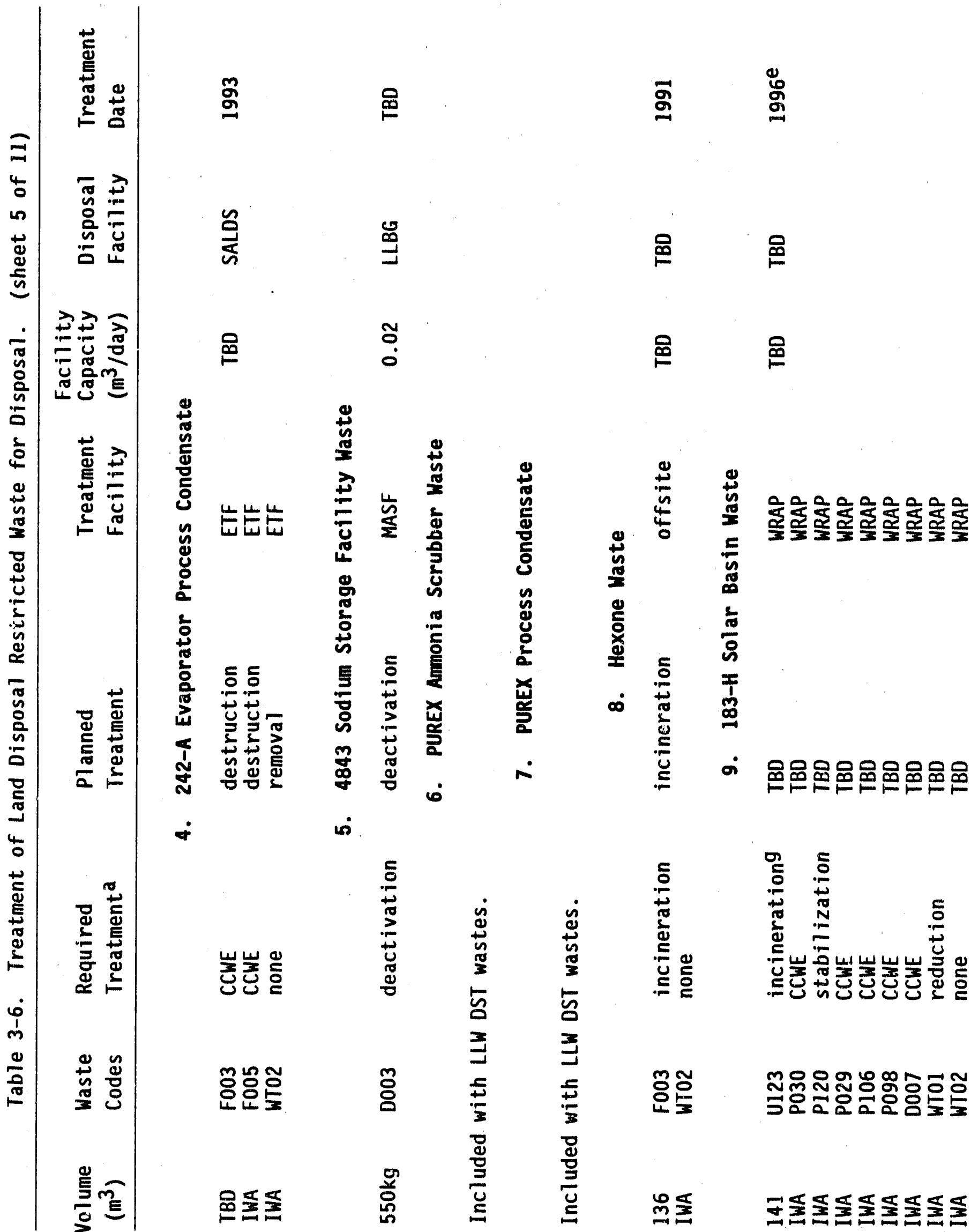

T3-6.5 
DOE/RL-90-41

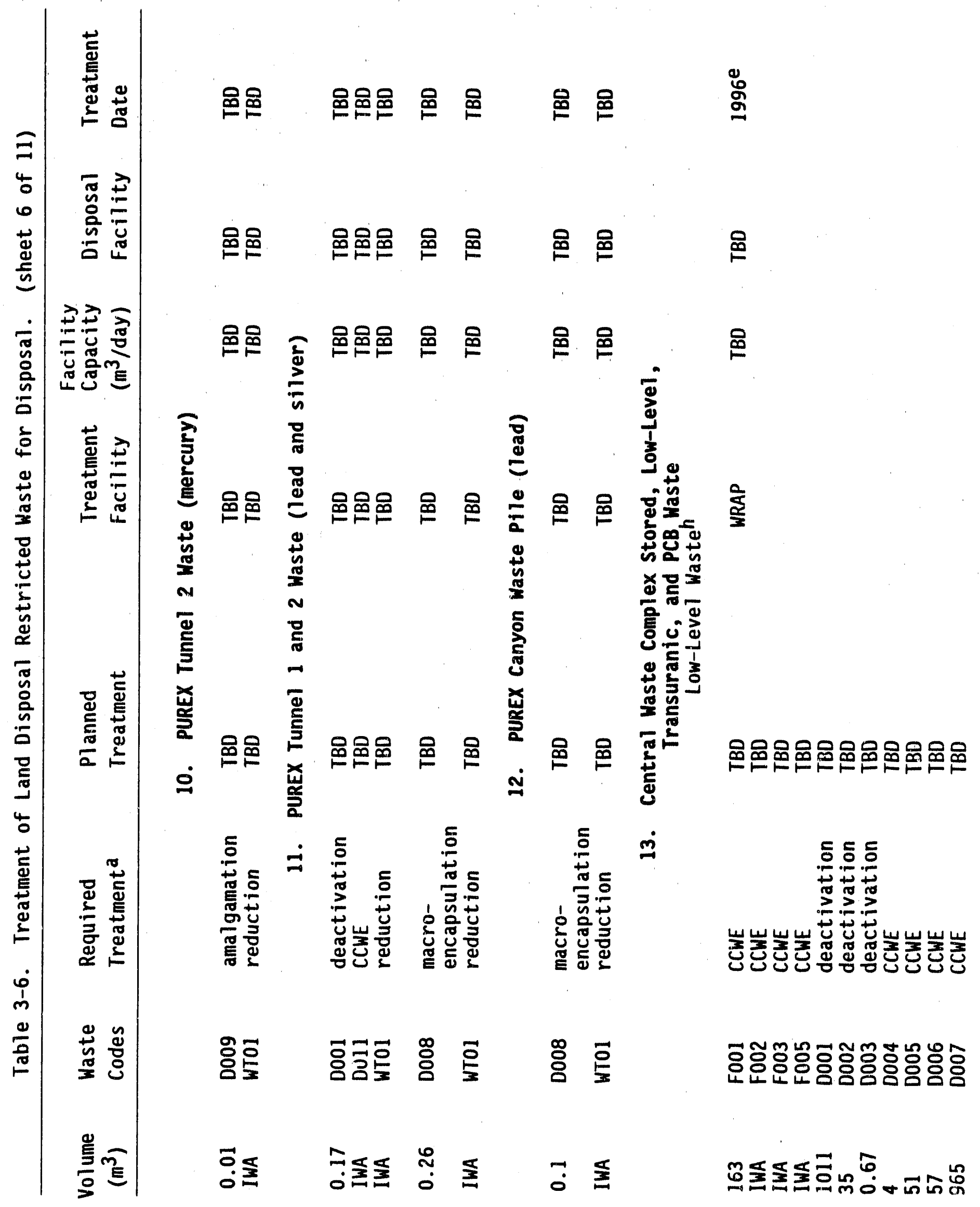




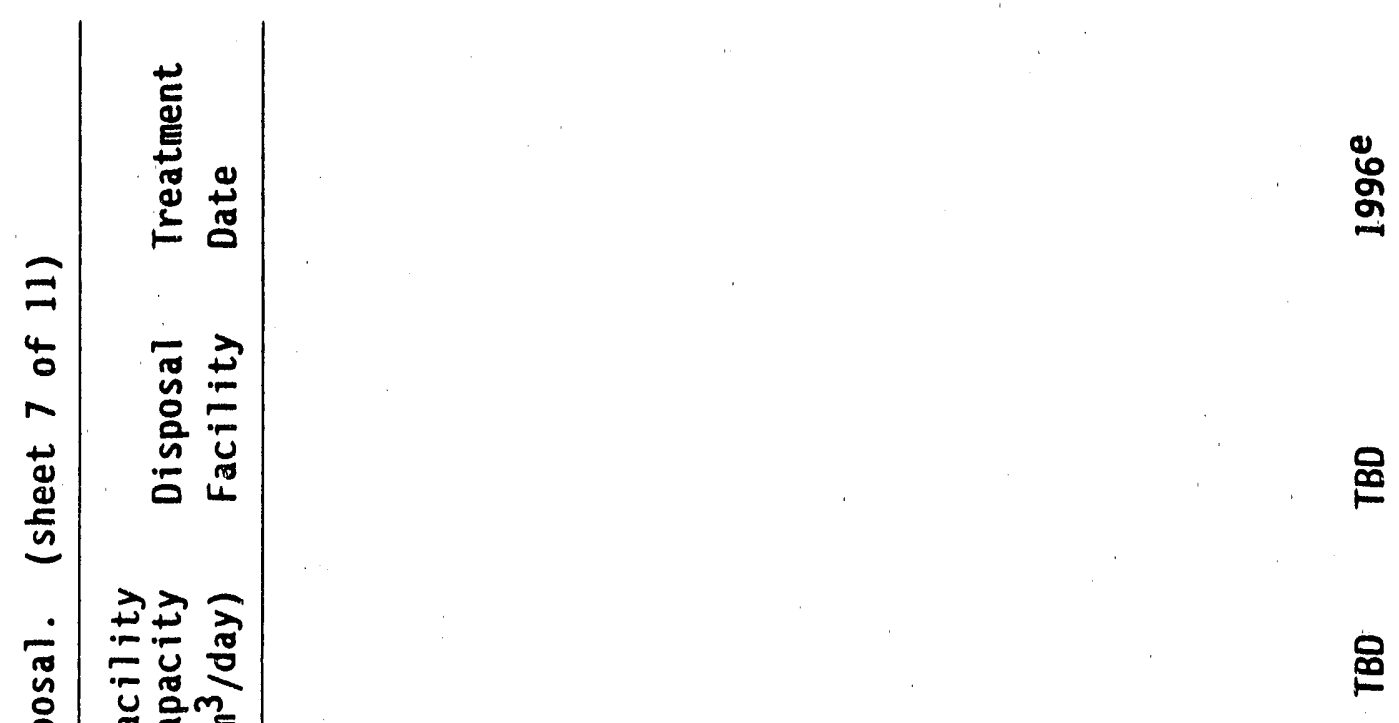

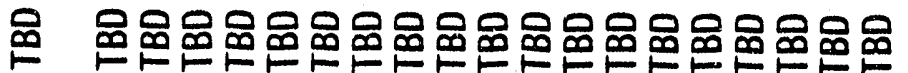
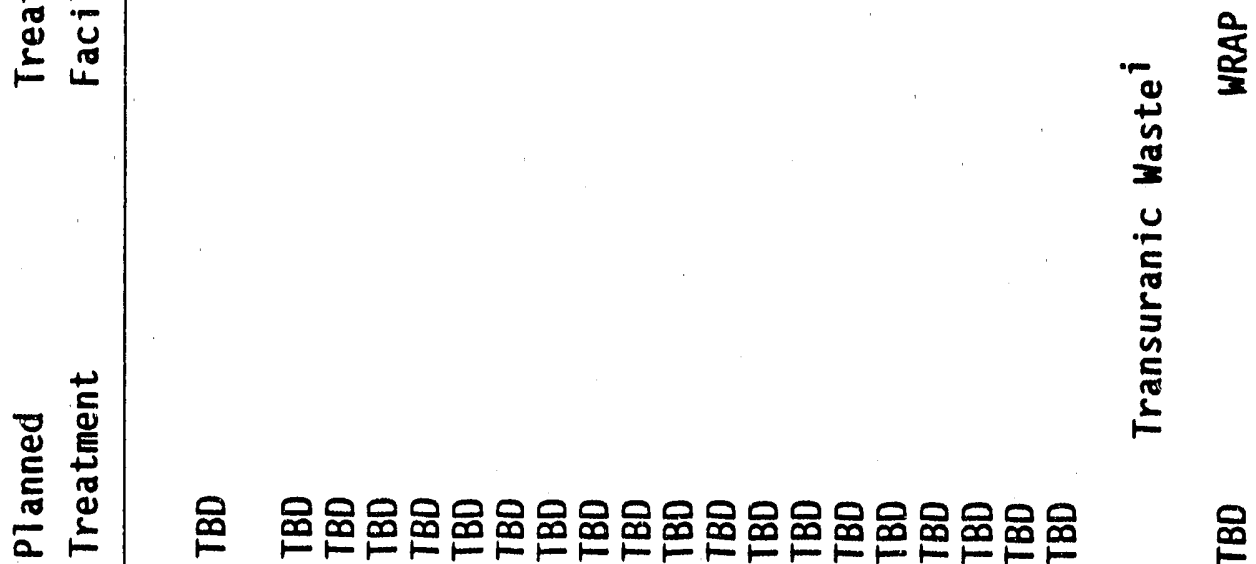

里

웅

के 


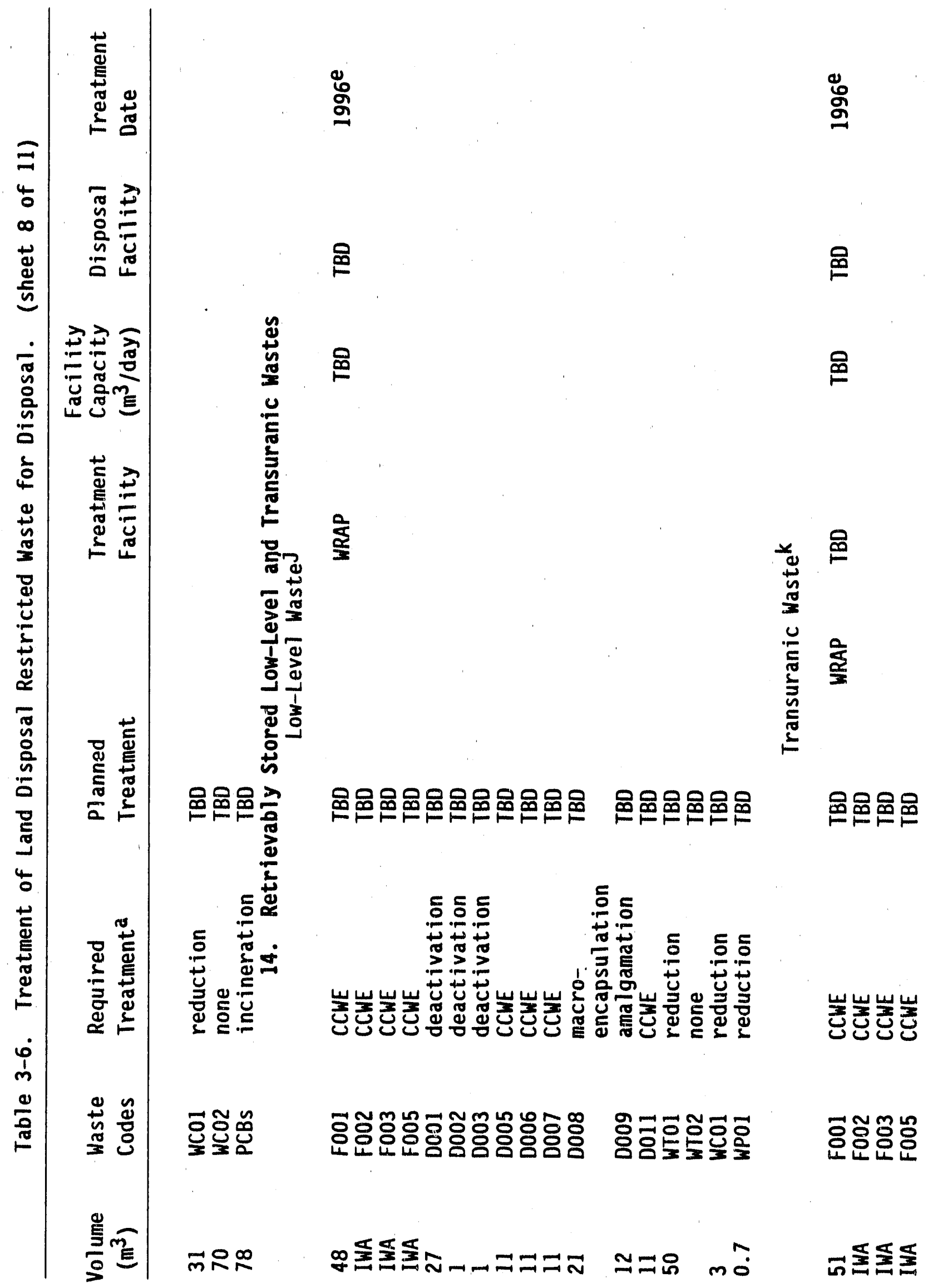




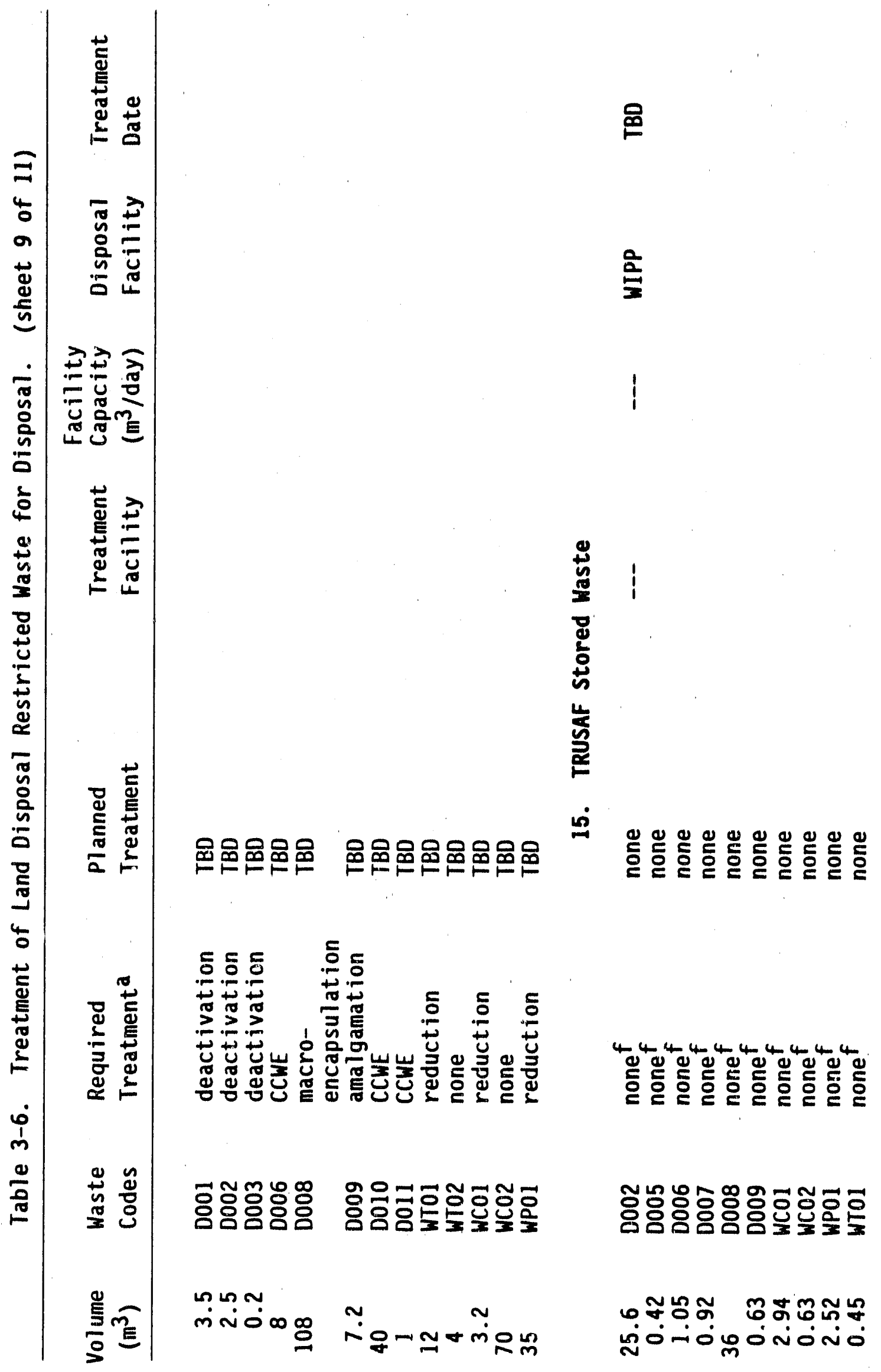




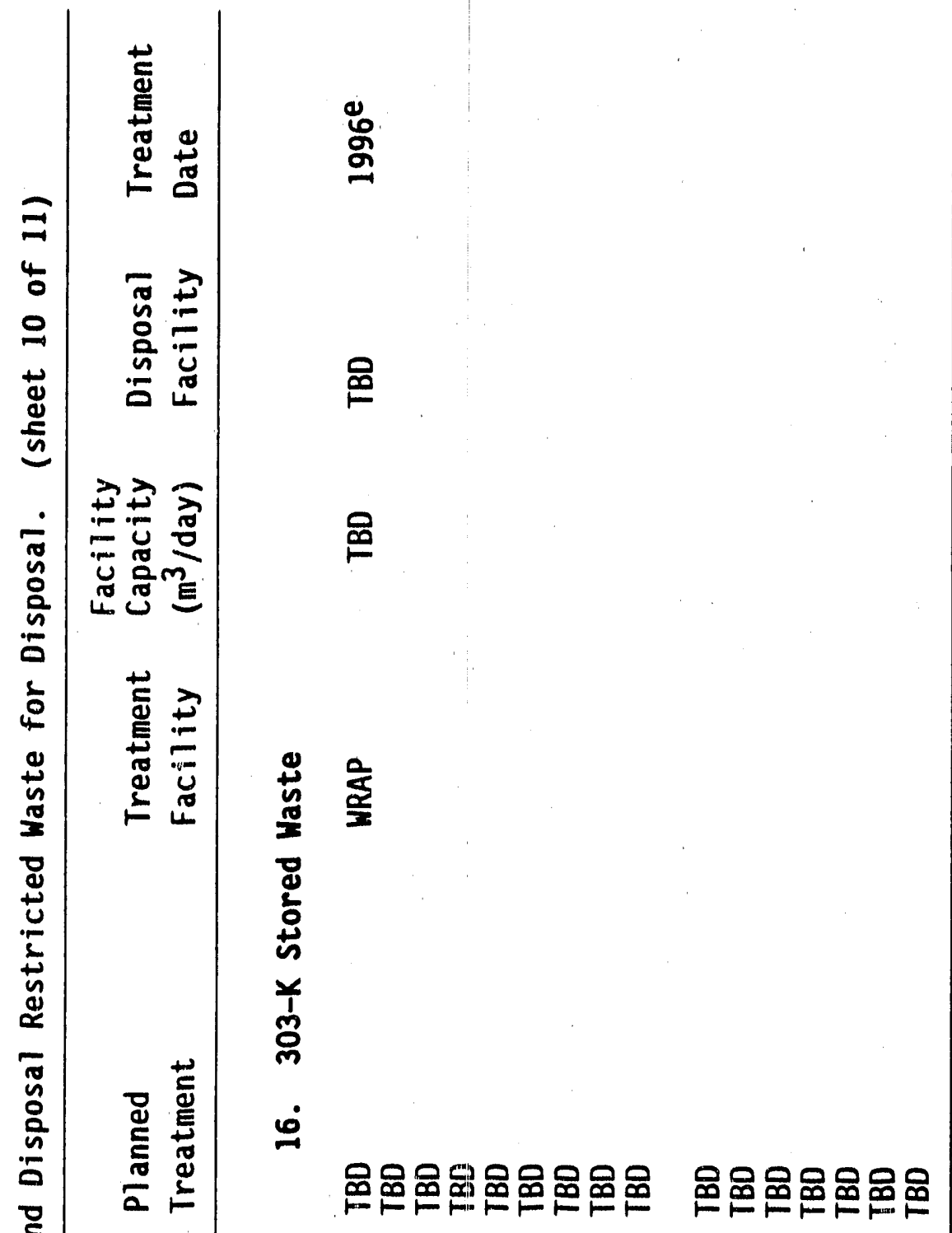

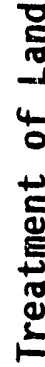

$\dot{0}$
$\dot{1}$
$\frac{0}{0}$
$\frac{0}{0}$

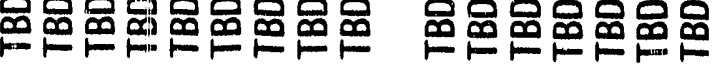

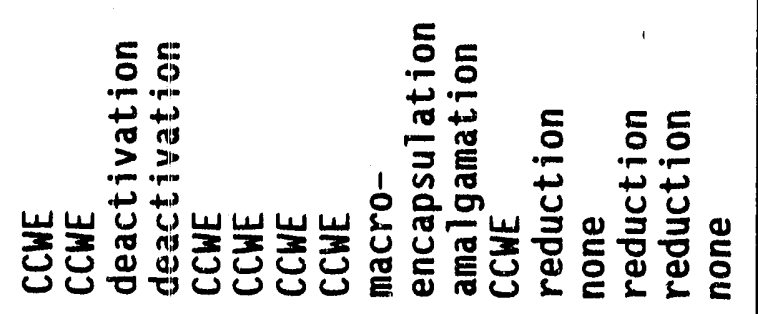

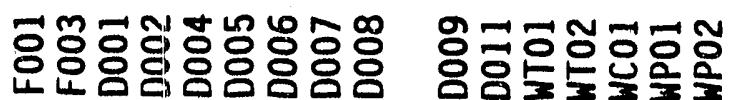
它

$\infty$

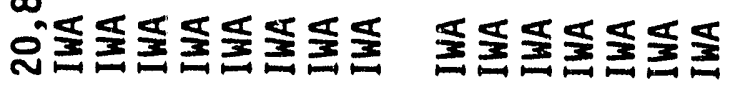

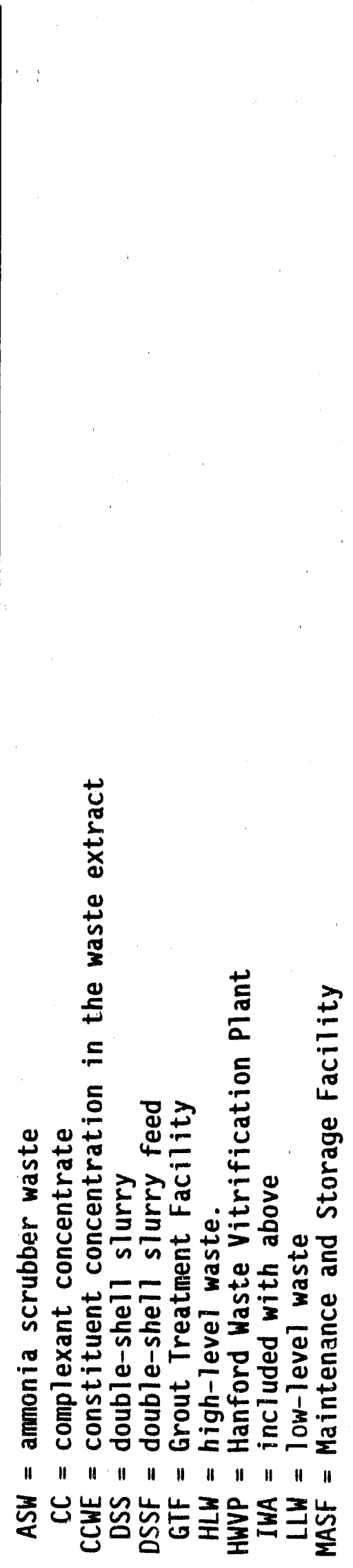




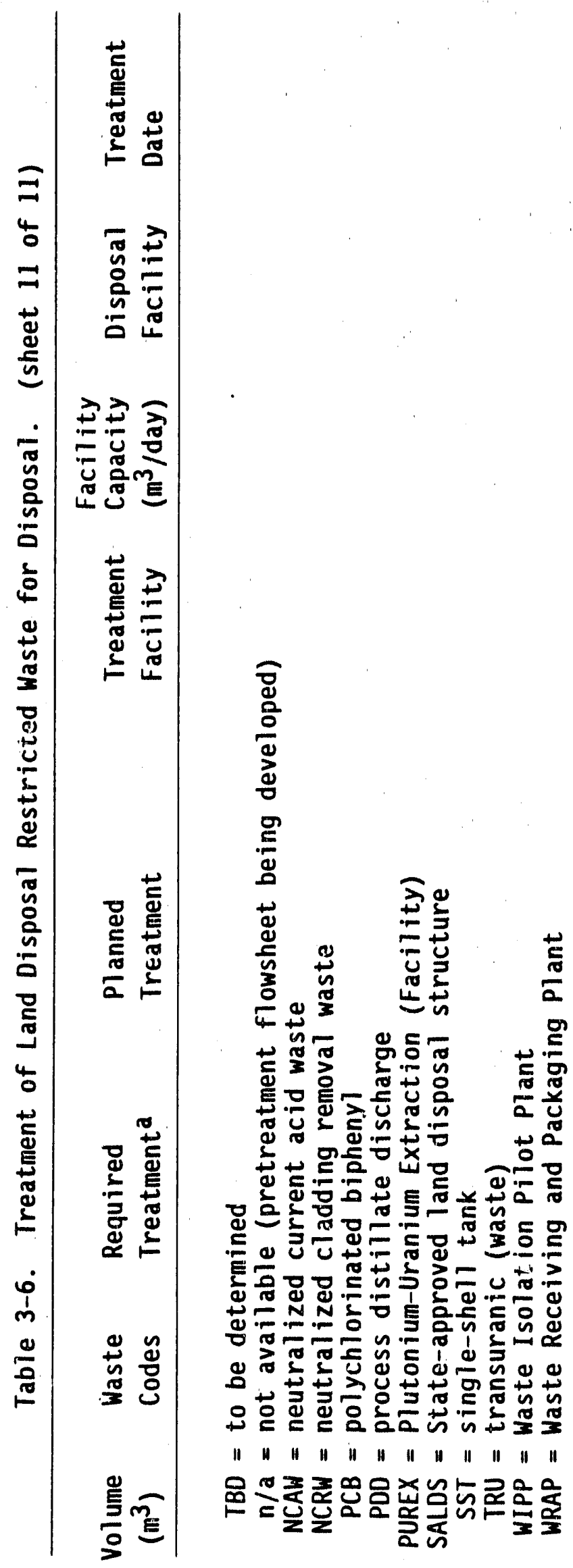

ธ

芦

ฐ

$\div \equiv \underset{0}{0}$

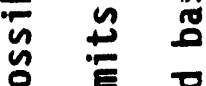

:

告

崩

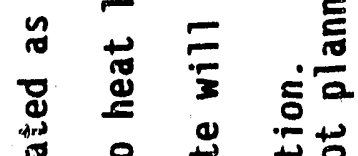

峁

\)

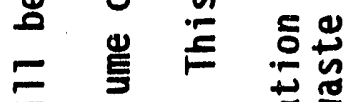

×

ㄱํำ

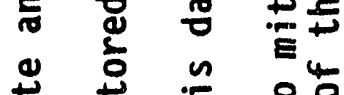

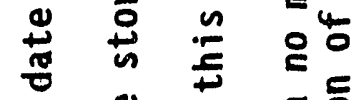

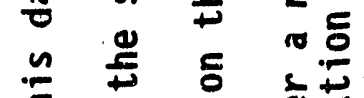

Е

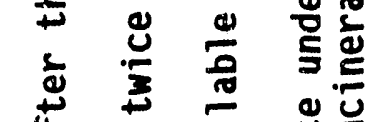

$\therefore$ 菏 㚿

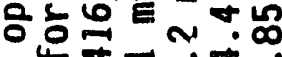
二

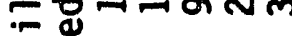

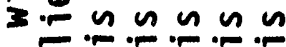

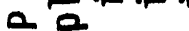
ล응

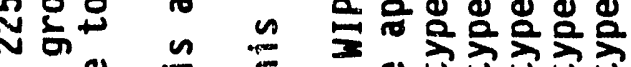

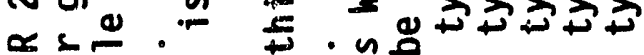

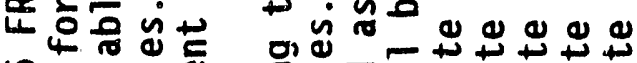

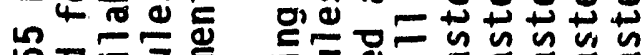

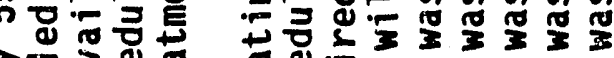

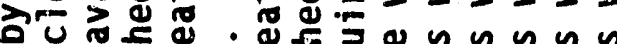

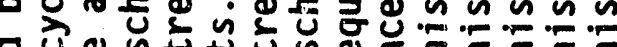

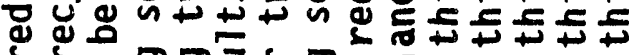
L

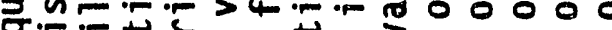

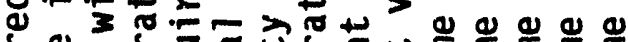

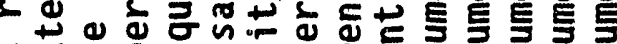

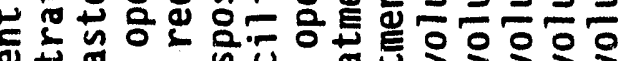
क्ष

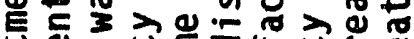
出 U

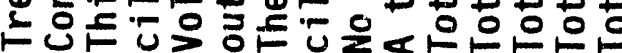

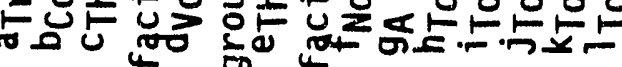


Table 3-7. Waste Minimization Activities for Hanford Land Disposal Mixed Wastes. (sheet 1 of 2)

\begin{tabular}{|c|c|c|c|}
\hline Waste & Mether to Minimize & $\begin{array}{l}\text { Schedule for } \\
\text { Implementing } \\
\text { Waste } \\
\text { Minimization } \\
\text { Procedures }\end{array}$ & $\begin{array}{l}\text { Projected } \\
\text { Waste } \\
\text { Reduction }\end{array}$ \\
\hline $\begin{array}{l}\text { 1. Double-Shell } \\
\text { Tank Waste }\end{array}$ & $\begin{array}{l}\text { - Evaporation } \\
\text { - Minimize frequency } \\
\text { of flush } \\
\text { - Minimize flush } \\
\text { volumes } \\
\text { - Pretreat waste } \\
\text { (e.g., destroying } \\
\text { ammonia) } \\
\text { - Recycle streams }\end{array}$ & underway & $80 \%$ \\
\hline $\begin{array}{l}\text { 2. PUREX Aging } \\
\text { Waste }\end{array}$ & $\begin{array}{l}\text { Optimum control of } \\
\text { the evaporator } \\
\text { waste flow concentration } \\
\text { overflow rate } \\
\text { - Reduction of Al/F } \\
\text { ratio in aluminum } \\
\text { nitrate nonhydrate } \\
\text { addition to the } \\
\text { dissolvers } \\
\text { - Evaporation }\end{array}$ & underway & $\begin{array}{l}\text { TBD } \\
\text { TBD } \\
21 \%\end{array}$ \\
\hline $\begin{array}{l}\text { 3. Single-Shell } \\
\text { Tank Waste }\end{array}$ & $\begin{array}{l}\text { - Waste is no longer } \\
\text { being added to SSTs }\end{array}$ & & $N / A$ \\
\hline $\begin{array}{l}\text { 4. } 242-A \text { Evap. } \\
\text { Process } \\
\text { Condensate }\end{array}$ & $\begin{array}{l}\text { - Effluent Treatment } \\
\text { Facility will remove } \\
\text { ammonia, aqueous, salts, } \\
\text { metal ions, and organics }\end{array}$ & 1992 & $>99 \%$ \\
\hline $\begin{array}{l}\text { 5. } 4843 \text { Sodium } \\
\text { Storage } \\
\text { Facility Waste }\end{array}$ & $\begin{array}{l}\text { - Recycle some of the } \\
\text { waste sodium at } \\
\text { generation point (FFTF) } \\
\text { - Deactivate sodium by } \\
\text { converting it to } \\
\text { carbonate }\end{array}$ & underway & $\begin{array}{l}\text { variable } \\
>99 \%\end{array}$ \\
\hline $\begin{array}{l}\text { 6. PUREX Ammonia } \\
\text { Scrubber Waste }\end{array}$ & $\begin{array}{l}\text { - Evaporation } \\
\text { - Planned ammonia } \\
\text { destruction process }\end{array}$ & 1995 & $90 \%$ \\
\hline $\begin{array}{l}\text { 7. PUREX Process } \\
\text { Condensate }\end{array}$ & $\begin{array}{l}\text { - Evaporation } \\
\text { - Neutralization }\end{array}$ & 1993 & $100 \%$ \\
\hline 8. Hexone Waste & - Distill and incinerate & 1991 & $88 \%$ \\
\hline
\end{tabular}


Table 3-7. Waste Minimization Activities for Hanford Land Disposal Mixed Wastes. (sheet 2 of 2)

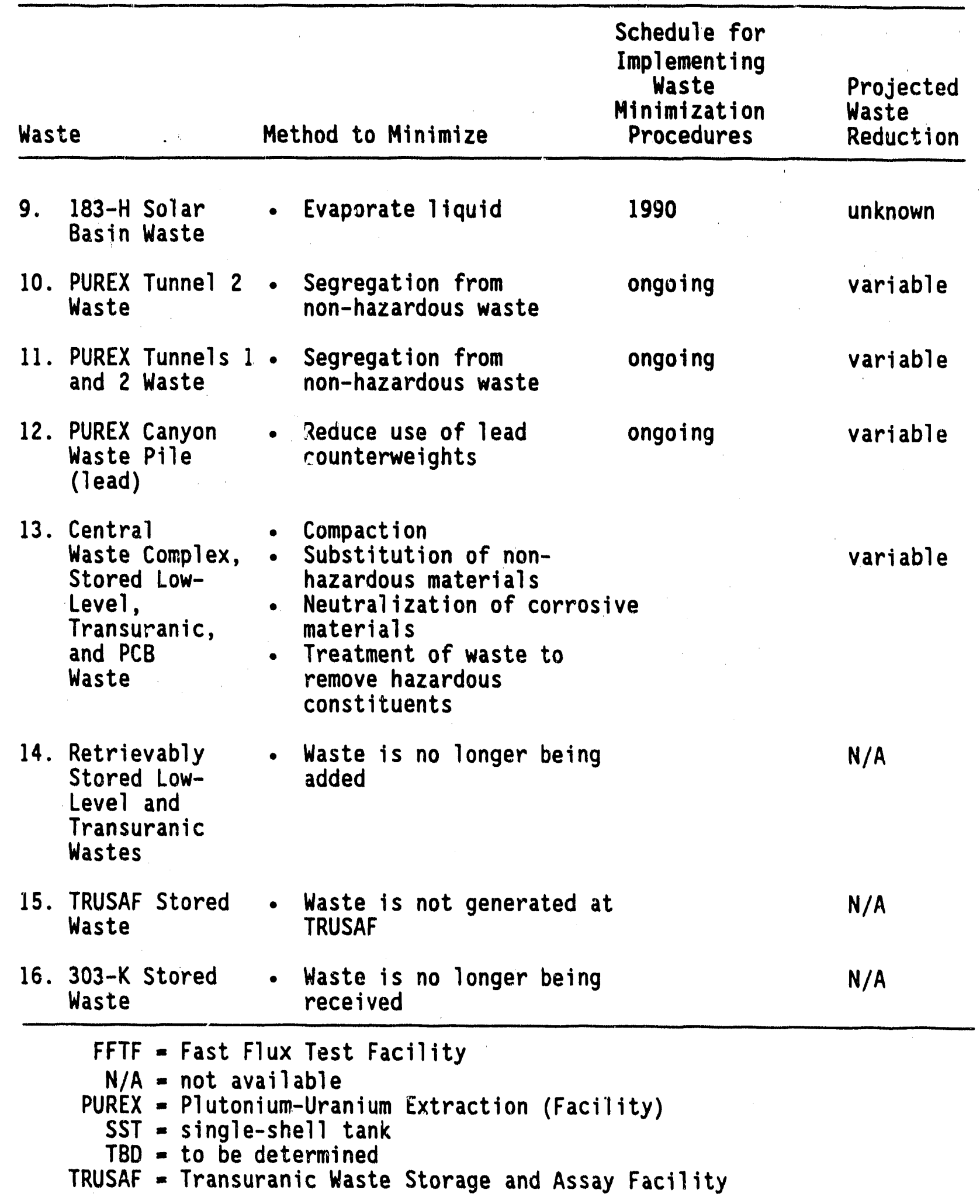




\subsection{INDIVIDUAL WASTESTREAM INFORMATION}

\subsection{DC:'3LE-SHELL TANK WASTE}

Double-shell tank waste is generated during the production of nuclear materials. The double-shell tank waste is stored as alkaline liquids and solids in double-shell underground storage tanks in the 200 East and 200 West Areas on the Hanford Site. There are 28 double-she 11 tanks that currently store about 79,100 cubic meters of waste (WHC 1990a). Two of these double-shell tanks contain PUREX aging waste and are addressed separately in Section 4.2.

The double-shell tank waste is generated from the PUREX process, research and development programs, laboratories, and decontamination of plants and equipment. Liquid supernatant and interstitial liquids from single-shell tank also are pumped to double-shell tanks for storage.

Treatment plans are to recover the contents of the tank and immobilize them for disposal. The transuranic and high-level fractions will be vitrified for disposal in a geologic repository; the low activity fraction will be converted to grout for disposal in near-surface vaults at the Grout Treatment Facility.

Projected generation rates for double-shell tank waste fluctuate depending on the operating schedules of the waste generating units. The startup of planned treatment and disposal units will decrease the current and future double-shell tank waste volumes. Even so, under certain scenarios, all double-shell tanks could be filled to capacity before 1997.

\subsubsection{Generation}

Double-shell tank waste is generated by operations in the $100,200,300$, and 400 Areas of the Hanford Site. The first double-shell tanks were constructed in 1970 and the newest double-she11 fanks were completed in 1986.

4.1.1.1 Process. The tanks contain waste from current operations and waste from past chemical separations nrorsesses. The major contributors to the waste stored in double-shell tanks are discissed in the following sections. All wastestreams transferred to the double-shell tanks for storage are treated with sodium hydroxide and sodium nitritie to minimize tank corrosion. In addition to newly generated waste, liguid waste stored ir single-shell tanks also is transferred to the double-shell tanks. This waste originated from the same sources as that stored in the double-shell tanks. These sources include the PUREX Plant and B Plant chemical processes as weli as bismuth phosphate separations, uranium recovery, and reduction-oxidation extraction prucesses. Descriptions of these processes are included below (DOE 1987).

4.1.1.1.1 The PUREX Process. The PUREX process is a solvent extraction process that uses a tributyl phosphate in a kerosene-like solvent for recovering uranium and plutenium from nitric acid solutions of irradiated uranium. Laboratory waste and f?ush water also are sent to the double-shel? 


$$
\text { DOE/RL-90-41 }
$$

tanks from the PUREX Plant. The PUREX Plant began operation in 1956 and has operated intermittently since then.

4.1.1.1.2 Plutonium Finishing Plant. In 1949 the Plutonium Finishing Plant began converting plutonium in solution to plutonium metal. This historic wastestream was high in metallic nitrates. The process was comprised of precipitation, solvent exchange, and ion exchange. The current wastestream generated from the Plutonium Finishing Plant is high in metallic hydroxides generated from plutonium reclamation, plutonium metal conversion, and laboratory operations.

4.1.1.1.3 Bismuth Phosphate Separations. Beginning in the early 1940s, the $B \quad P l a n t$ and $T$ Plant separated plutonium from uranium in irradiated fuel by coprecipitation with bismuth phosphate from a uranyl nitrate solution. The plutonium was further separated from fission products by successive precipitation cycles using bismuth phosphate and lanthanum fluoride. Waste containing uranium, acid, and many of the fission products was neutralized and stored in underground single-shell tanks. This separation process was used from 1943 to 1957.

4.1.1.1.4 Uranium Recovery Process. Uranium in process waste was mined from the single-shell tanks by sluicing, dissolved in nitric acid, and processed through a solvent extraction process using tributyl phosphate in a kerosene-like solvent. The acid waste from the uranium recovery process was made alkaline and returned to single-shell tanks. The recovery process, which operated from 1952 to 1958, resulted in an increase in the volume of nonradioactive salts and a small increase in waste volume.

4.1.1.1.5 Reduction-0xidation Process. The reduction-oxidation process used a continuous solvent extraction process to extract plutonium and uranium from dissolved fuel in a hexone solvent. The slightly acidic wastestream contained the fission products and large quantities of aluminum nitrate. This waste was neutralized and stored in single-shell tanks. The 202-S Plant operated between 1951 and 1967.

4.1.1.1.6 Other Cont: ibutors to Double-She11 Tank Waste. Cleaning solutions and other miscellaneous waste are chemically adjusted to minimize tank corrosivity and transferred to double-shell tanks for storage. The waste includes the following:

- Spent cleaning solutions from decontamination and ion exchange regeneration at the 100 Area

- Waste from decontaminating and decommissioning tools and equipment

- Laboratory waste from the 200 Area

- Fuels fabrication waste from the 300 Area

- Miscellaneous waste from the Fast Flux Test Facility operations in the 400 Area.

4.1.1.2 Generation. Double-shel1 tanks dn not simply accumulate and store waste; the tanks are a waste-handling system. The inflows to the system 
include the PUREX and other production waste, interstitial liquids pumped from single-shell tanks, and B Plant waste. Outflows include evaporation, grout, and vitrification processes. Evaporation decreases the double-shell tank waste volume and separates organic from inorganic constituents; grout and vitrification remove double-shell tank waste and solidify it for disposal.

Projected double-shell tank waste generation for 1990 through 1995 is shown in Table 4-1 in terms of volume before and after evaporation. The average generation rate for double-shell tank waste is 8,950 cubic meters per year before evaporation. This generation rate is based on waste generation trends through May 1990 and budget planning and Tri-Party Agreement schedules as of May 30, 1990. The projection also incorporates many assumptions, including the operation of the 242-A Evaporator and B Plant. These assumptions are detailed in Chapter 2.0, Section 2.2.

\subsubsection{Characterization}

The waste in double-shell tanks is solid, liquid, and sludge; low-level and transuranic waste; and is designated as ignitable, corrosive, toxic, persistent and carcinogenic extremely hazardous waste. Because of heavy metals contamination, double-shell tank waste also is designated as toxic by the TCLP.

This section summarizes process knowledge and sample analysis for the contents of the double-shell tanks. The assumed waste designations and their bases are described, and schedules for further analysis are given.

4.1.2.1 Process Knowledge. Several processes contribute to double-shell tank waste, as described in Section 4.1.1.1. Waste management practices, including evaporation of tank contents, have intermingled the various types of waste. This intermingling precludes a detailed, quantified characterization of the contents of the tank based strictly on process knowledge. Instead, the double-shell tank waste is described qualitatively based on generation data and sample analysis.

Stratification and segregation have occurred in the tanks as solids have settled out. The consistency of the waste ranges from liquid supernatant to a thick sludge. The sludge is formed by solids that precipitate when sodium hydroxide is added to raise the $\mathrm{pH}$ above 12.5 to minimize tank corrosion.

The major constituents of double-shell tank waste are sodium salts of aluminate, nitrate, nitrite, phosphate, carbonate, and sulfate. Some calcium and potassium salts also are present. Complexed waste in the double-shell tanks contains the chelating agents ethylenediaminetetraacetic acid and n-hydroxyethylethylenediamine-tetraacetic acid. There al so may be detectable concentrations of halogenated and nonhalogenated organic compounds and heavy metals such as lead, chromium, and cadmium.

4.1.2.2 Sample Analyses. Samples of the double-shell tanks have been analyzed. Because no one double-shell tank constitutes a "representative" tank, the analytical data from these samples are presented in Table 4-2 as ranges of values for tank composition. 
DOE/RL-90-41

4.1.2.3 Waste Designation and Basis. All waste stored in the double-shell tanks is designated corrosive dangerous waste (D002) because it has been treated with sodium hydroxide to raise the $\mathrm{pH}$ above 12.5 in preparation for tank storage.

The double-shell tank waste is assumed to be extremely hazardous waste (WTO1) for toxicity based on the concentration of chemicals in the waste. The waste may exhibit the characteristic of ignitability (D001) as identified in Washington Administrative Code (WAC) 173-303-090 because of the presence of oxidizers such as nitrate and nitrite. The waste has not been tested for ignitability. This designation currently is being reevaluated. Double-shell tank waste also is suspected to contain the spent solvents hexone and acetone (waste code F003). The double-shell tanks contain waste that is characteristic TCLP toxic for heavy metals contamination: arsenic (D004), barium (D005), cadmium (D006), chromium (D007), lead (D008), mercury (D009), selenium (DO10), and silver (DO11). The waste also is carcinogenic (WCO1, WCO2) and persistent (WPO1, WPO2).

The double-shell tanks do not contain waste listed on the dangerous waste source list of WAC 173-303-282.

4.1.2.4 Uncertainty of Waste Designation. The waste codes assigned previously are considered accurate, but additional waste codes may be added or deleted based on the ongoing characterization program.

4.1.2.5 Schedule for Further Characterization. Sampling and analys is of the double-shell tank contents is underway and is scheduled to continue through 1993 (WHC 1989a).

The analysis protocol will follow the EPA test methods for Evaluating Solid Waste (SW-846), with Ecology-approved deviations, and include sample analyses of physical characteristics, 33 inorganic compounds, volatile organics, and radiuisotopes. The streams also will be characterized before and after treatment (Section 4.1.4).

\subsubsection{Storage}

This section describes double-shell tank storage and assesses its compliance with existing regulations.

4.1.3.1 Storage Unit and Capacity. There are 28 double-she 11 tanks, each with a 4,300-cubic-meter capacity. Four of these double-shell tanks are equipped to manage PUREX aging waste and are addressed separately in Section 4.2. The 28 tanks are located in 6 tank farms in the 200 East and 200 West Areas of the Hanford Site.

4.1.3.2 Amount in Storage. As of May 1990, the tanks held about 79,100 cubic meters of waste (WHC 1990a). Projections indicate that the double-shell tanks could be filled to capacity before 1997 based on current expected generation rates. Efforts currently are underway to identify the required changes to operations to ensure that sufficient tank space is available. Options being investigated include increased grout operations and delay of processing campaigns and enhanced waste minimization activities. 
4.1.3.3 Storage Compliance Assessment. The double-shell tanks were reviewed for compliance with interim status dangerous waste regulations in accordance with the Tri-Party Agreement milestone number M-21-00 (Ecology et a1. 1989). The assessment for compliance with interim status regulations noted the following areas of noncompliance (DOE/RL 1990f):

- Inspection plan

- Waste analysis plan

- Waste characterization

- Training plan.

Compliance action schedules for double-shell tanks are being negotiated in the Tri-Party Agreement. Interim status compliance for the items listed is scheduled to be achieved by December 1990. Additional double-shell tank actions may be required after December 1990 . These actions may include the following:

- Recordkeeping system modifications

- Provision of secondary containment for ancillary equipment

- Development of additional leak detection systems

- Development of a closure plan.

\subsubsection{Treatment}

This section discusses current and proposed treatment of double-shell tank waste.

4.1.4.1 Current Treatment. The 242-A Evaporator reduces the double-shell tank waste volume by evaporative concentration and separates volatile organic solvents from the inorganic constituents (Section 4.4.1.1). It began operating in 1977 and has evaporated more than 246,000 cubic meters of water from the stored waste.

4.1.4.2 Proposed Treatment. The double-shell tank waste will be retrieved, pretreated (as required), and solidified for disposal. A pictorial flow diagram and a process flow diagram are shown in Figures 4-1 and 4-2

(WHC 1989a). The transuranic fraction of the tank waste will be vitrified and disposed of in a geologic repository. High-level double-shell tank waste (aging waste) is addressed separately in Section 4.2. The low-level fraction will be converted to cementitious grout for disposal in near-surface vaults. Grout disposal is being conducted under a RCRA permit (DOE/RL 1990g) and in compliance with applicable DOE orders.

Four waste types have been identified as feed to the vitrification plant, after pretreatment (WHC 1990b):

- Neutralized current acid waste (PUREX aging waste)

- Complexant concentrate

- Plutonium Finishing Plant waste

- Neutralized cladding removal waste.

Pretreatment consists of separating the waste into a low-volume, transuranic waste fraction (for vitrification), and a low activity waste fraction (for 
DOE $/$ RL $-90-41$

grout). Certain other double-shell tank waste types (double-shell slurry and double-shell slurry feed) are directly disposed of as grout without pretreatment.

\subsection{Definition and Treatment of Double-Shell Slurry Feed and} Double-Shell slurry Waste. Double-shell slurry feed is generated by concentrating the dilute wastestreams generated by the operating plants to conserve storage space. Double-shell slurry is generated by further concentration of double-shell slurry feed.

Double-shell slurry feed and double-shell slurry are retrieved from the double-shell tanks and treated for disposal at the Grout Treatment Facility. (DOE/RL 1990g). The treatment of these waste types at the Grout Treatment Facility is scheduled to begin in June 1991 (milestone M-01-00, Ecology et al. 1989).

4.1.4.2.2 Definition and Treatment of Neutralized Current Acid Waste. Neutralized current acid waste is PUREX aging waste. Further discussion of neutralized current acid waste is contained in Section 4.2 .

\subsection{Definition and Treatment of Neutralized Cladding Removal}

Solids Waste. Cladding removal waste results from dissolving the zircaloy cladding of irradiated nuclear fuel from $N$ Reactor. Neutralizing the waste precipitates most of the zirconium and creates a slurry. The resulting s.tream is called neutralized cladding removal waste.

Treatment of neutralized cladding removal waste begins by separating solids from any remaining liquid. The resulting liquid is a low-level waste that goes to grout treatment. Most of the solids are dissolved with nitric acid, and the dissolved transuranic elements are separated from the undissolved solids and used as feed for a transuranic-extraction process.

The transuranic-extraction process separates the transuranic radionuclides and the nontransuranic constituents of the waste, resulting in a small volume of concentrated transuranic waste stream and a low-level wastestream. The concentrated transuranic stream is recombined with the undissolved solids and sent to the vitrification plant. The low-level wastestream is returned to the double-shell tanks for evaporation and ultimately is disposed of by grouting.

Pilot-plant tests of the pretreatment process for neutralized cladding removal waste are scheduled for 1993. Pretreatment of the neutralized cladding removal waste is scheduled to begin in 1998, with vitrification of the treated waste scheduled for 2002 (WHC 1989a).

4.1.4.2.4 Definition and Treatment of Plutonium Finishing Plant Waste. The Plutonium Finishing Plant waste originates from the conversion of plutonium nitrate to oxide or metal and includes transuranic laboratory waste, high-salt solvent extraction waste and organic wash waste. As of May 1990, 390 cubic meters of this waste is in storage (WHC 1990a). Projected generation of this waste through 1995 is 1,150 cubic meters. Treatment of Plutonium Finishing Plant waste is the same as treatment of neutralized cladding removal waste described in Section 4.1.4.2.2. Pilot-plant testing of the Piutonium Finishing Plant waste treatment is scheduled for 1994 and 
full-scale treatment of the waste is scheduled to begin in the year 2000, with vitrification of the treated waste scheduled for 2004 (WHC 1989a).

4.1.4.2.5 Definition and Treatment of Complexant Concentrate Waste. The complexant concentrate results from the concentration of waste containing large amounts of organic complexing agents. The organic complexing compounds were introduced to the waste during strontium recovery at B P1ant. As of May 1990, 15,450 cubic meters of this waste was in storage. No future generation of this waste is planned.

Treatment of the complexant concentrate begins with acidifying the stream to dissolve as many of the solids as possible. The liquid is separated from the undissolved solids and used as feed to the transuranic-extraction process. The transuranic-extraction process separates a low-volume transuranic concentrate wastestream from a low-level wastestream containing organics and possibly cesium. The low-level wastestream is treated to destroy organics and, if necessary, the cesium is removed. The resulting low-level wastestream then goes to grout treatment. The transuranic concentrate stream is added to the undissolved solids and eventually vitrified.

Pilot-plant testing of the complexant concentrate waste treatment is scheduled for 1995. Ful1-scale processing of complexant concentrate waste is scheduled for 2001. Vitrification of the pretreated waste is scheduled for 2004 (WHC 1989a).

\subsubsection{Minimization}

Currently, 12 major plants generate double-she11 tank waste. During the past 5 years these plants have consistently reduced their total yearly volume of waste sent to the double-shell tanks. This significant reduction of waste results partly from shutting down some operations and partly from waste treatment. Waste minimization activities (current and planned) are outlined for each unit in the Annual Report of Tank Waste Treatability Studies (WHC 1990b). The four activities include minimizing flush volumes and frequency, pretreating waste (e.g., destroying ammonia), modifying processes, and recycling streams.

Dilute waste received at the double-shell tanks is concentrated by the 242-A Evaporator, further reducing the waste volume by $30 \%$ to $95 \%$. In an average year, projected volumes of dilute waste will be reduced by approximately $71 \%$ (Section 4.1 .1 .2 ).

\subsubsection{Variances, Exemptions, Time Extensions}

The double-shell tank waste consists of high-level waste, transuranic waste, and low-level waste containing dangerous waste constituents. The double-shell tank waste is restricted from land disposal because it contains solvent waste (40 CFR 268.30) and California list waste (40 CFR 268.32). It also contains waste covered by the Third Third Promulgation ( 55 FR 22520).

The Third Third Promulgation (55 FR 22520) provided for a 2-year national capacity variance from the land disposal restrictions for Third Third mixed 
waste. This variance allows continued storage of these wastes. In the event that sufficient treatment capacity for this waste is not available at the expiration of this variance (August 1992), the Tri-Party Agreement will allow continued storage of this waste until sufficient treatment capacity is available in accordance with the schedules in the agreement.

The Tri-Party Agreement (Ecology et al. 1989) provides for continued storage of California list ( 40 CFR 268.32) and solvent waste (40 CFR 268.30) until treatment capacity is developed for these wastes. The agreement requires treatment and disposal capacity for these wastes to be developed on the following schedule:

- Low-Level Waste - Disposal of treated waste in grout as soon as sufficient quantities are available to facilitate proper treatment and disposal, in accordance with the grout schedule defined in the TriParty Agreement that requires 14 grout campaigns by September 1994

- Transuranic Waste - Treatment schedules for transuranic waste stored in the double-shell tanks (complexed concentrate, neutralized cladding removal waste, solids, and Plutonium Finishing Plant solids) currently are being negotiated and will be incorporated into the Tri-Party Agreement (Ecology et a1. 1989) - when they are approved by all three parties to the agreement.

If additional variances, exemptions, or extensions of time are required as a result of delays in the development of treatment, storage, or disposal capacity, they will be applied for in accordance with the procedures detailed in the Tri-Party Agreement (Ecology et a1. 1989).

\subsection{PUREX AGING WASTE}

The aging waste storage unit comprises four double-shell storage tanks in the 241-AY (Tanks $A Y-101$ and $A Y-102$ ) and 241-AZ (Tanks $A Z-101$ and $A Z-102$ ) tank farms in the 200 East Area of the Hanford Site. Two double-shell tanks, designated 241-AZ-101 and 241-AZ-102, presently hold a mixture of solids and supernate aging high-level waste (from the PUREX PIant).

Aging waste from the PUREX Plant comes from the first decontamination solvent extraction column in the PUREX solvent extraction process. The feed to the extraction column is irradiated fuel eiements dissolved in nitric acid. The extraction column separates the uranium and transuranic products from the majority of the fission products. The fission products are contained in the aqueous nitric acid phase from the extraction column. The aqueous phase is concentrated to recover nitric acid and reduce volumes, and the concentrated stream is sampled. If based on sample analysis it is determined to be a waste, it is treated with sugar to destroy the majority of the nitric acid. Sodium hydroxide is added to meet storage tank specifications and the waste is transferred to the aging double-shell tanks for storage. As of May 1990, a total of 7,300 cubic meters of PUREX aging waste was in storage.

The wastestream is considered corrosive and toxic and has designated EPA waste codes of D002, D006, D007, and D008. The wastestream will be treated at ¿ Plánt fúr separation of the high-ievel waste from the low-level waste. The 
low-level fraction will be transferred to the Grout Treatment Facility for disposal and the high-level fraction will be vitrified at the Hanford Waste Vitrification $\mathrm{Pl}$ ant and disposed of in a repository.

\subsubsection{Generation}

This section describes the waste generation process. If, as a result of the Environmental Impact Statement for the disposition of stored reactor fue 1 , the PUREX Plant is the preferred option, estimates of the future generation rate will be provided after the PUREX Plant restart plans have been developed.

The PUREX Plant receives irradiated zirconium $c l a d$ fuel from $N$ Reactor, removes the cladding from the fuel and dissolves the fuel in nitric acid. The dissolved fuel is processed through several solvent extraction stis to separate the plutonium, uranium, and neptunium from the fission products contained in the fuel. The aging waste contains the majority of the fission products from the fuel and is generated from the aqueous stream from the first extraction column.

\subsubsection{Characterization}

This section discusses the available waste characterization inforination. Information based on process knowledge and sample analys is is provided along with the waste designations and their bases, the uncertainty related to the designation, and the schedule for further analysis.

4.2.2.1 Process Knowledge. The aging wastestream is made up of water, aluminum hydroxide, sodium nitrate, sodium hydroxide, sodium fluoride, cadmium nitrate, sodium nitrite, corrosion products, and the majority of radionuclides from the $N$ Reactor fuel. Past practice (before 1989) was to recycile process samples analyzed in the laboratory back to the process system, which may have resulted in some of the chemicals added to the samples entering the aging waste. The presence of these chemicals in the aging waste never has been confirmed by sampla analysis.

4.2.2.2 Sample Analyses. The composition of PUREX aging waste (also known as neutralized current acid waste) is given in Table 4-3. The results of sample analyses of the PUREX aging waste stored in the double-shell tanks are given in Table 4-4.

4.2.2.3 Waste Designation and Dasis. The neutralized current acid wastestream contains excess amounts of sodium hydroxide ( $0.8 \mathrm{M})$ making the waste corrosive dangerous waste $(0002)$ and 1 and disposal restricted (52 FR 22520). Based on equivalent concentration calculations, there are sufficient concentrations of sodium nitrate and sodium hydroxide to make the aging waste toxic dangerous waste (WTO1). In addition, there are sufficient quantities of heavy metals to designate the neutralized current acid waste as a toxic, as determined by the toxic characteristic leach procedure, for cadmium (D006), chromium (D007), and possibly lead (D008).

4.2.2.4 Uncertainty of Waste Designation. Based on sample data from tanks

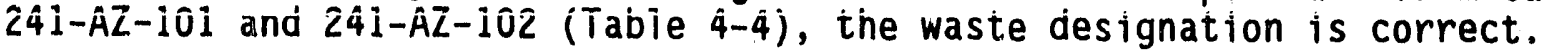


4.2.2.5 Schedule for Further Characterization. Twelve core samples of the waste will be characterized between October 1989 and September 30, 1992 (WHC 1989a).

\subsubsection{Storage}

This section provides the volume currently in storage and assesses the compliance status of the storage unit.

4.2.3.1 Storage Unit and Capacity. The aging waste storage unit comprises four double-shell storage tanks in the 241-AY and 241-AZ tank farms. Only the 241-AZ tank farm currently contains aging waste. The AY and $A Z$ aging waste tanks each have a maximum fill volume of 3,800 cubic meters. The use of airlift circulators limits the working volumes to 3,700 cubic meters for these tanks. These circulators keep the supernate agitated and aid in heat removal from the tanks. The tanks also are equipped with steam coils to boil away water in the waste and a ventilation system that can handle large amounts of steam.

4.2.3.2 Amount in Storage. Tanks 241-AZ-101 and 241-AZ-102 have waste inventories of 3,611 and 3,662 cubic meters, respectively (WHC 1990a). The waste is present in these tanks as neutralized current acid waste. If the PUREX Plant restarts, future waste projections will be determined after the PUREX Plant restart $\mathrm{plans}$ have been developed.

4.2.3.3 Storage Compliance Assessment. The PL'REX aging waste is stored in the double-shell tanks. The double-shell tanks were reviewed for compliance with interim status dangerous waste regulations in accordance with the Tri-Party Agreement milestone number M-21-00 (Ecology et al. 1989). The results of the compliance assessment are provided in Section 4.1.3.3.

\subsubsection{Treatment}

This section discusses the current and proposed waste treatment processes.

4.2.4.1 Current Treatment. Currently the aging waste is being stored pending pretreatment and vitrification.

4.2.4.2 Proposed Treatment. The neutralized current acid waste will be pretreated at B Plant in preparation for disposal. The Grout Treatment Facility converts the liquid low activity waste from the pretreatment process into cement-like grout. The Hanford Waste Vitrification Plant will incorporate high-level and transuranic waste into a glass matrix for disposal.

The major unit operations in the neutralized current acid waste pretreatment process in B PI ant are solid/liquid separation and washing, polishing filtration, cesium removal by ion exchange, and concentration of the cesium and low-level wastestreams (WHC 1989a). This process is illustrated in Figure 4-3 (WHC 1990b). 
The $B$ Plant is scheduled to initiate pretreatment of neutralized current acid waste in October 1993 (Tri-Party Agreement milestone M-02-01).

\subsubsection{Minimization} waste.

This section discusses the waste minimization practices for PUREX aging

4.2.5.1 Current Waste Minimization Practices. The production of high-level waste by the PUREX Plant has been reduced from 9,800 kilograms per day of operation in 1985 to 5,000 kilograms per day of operation in 1988 .

Minimization of aging waste was accomplished through increased process control of the aqueous stream concentration, better control of aluminum nitrate addition, and better control of sodium hydroxide addition to adjust wastestream pH to tank specifications. The minimization is graphically illustrated in Figure 4-4.

The following process improvements have been implemented and will continue to be used to minimize the PUREX aging waste volumes:

- Optimum control of the evaporator waste concentration overflow rate

- Reduction of the aluminum to fluoride ratio in the aluminum nitrate nonahydrate addition to the dissolvers during fuel processing.

\subsubsection{Variances, Exemptions, Time Extensions}

The PUREX aging waste consists of high-level waste mixed with dangerous waste constituents. The PUREX aging waste is a i and disposal restricted waste because of both the Third Third Promulgation (55 FR 22520) and the presence of California list constituents. The Tri-Party Agreement (Ecology et al. 1989) provides for continued storage of California list waste (40 CFR 268.32) until treatment capacity is developed for this waste. The agreement requires treatment and disposal capacity for this waste to be developed on the following schedule:

- Demonstrate pretreatment at B Plant by October 1993

- Initiate vitrification operations by December 1999

- Dispose of vitrified waste when repository opens.

The Third Third Promulgation (55 FR 22520) provided for a 2-year national capacity variance from the land disposal restrictions for Third Third mixed waste. This variance allows continued storage of these wastes. In the event that sufficient treatment capacity for this waste is not available at the expiration of this variance (August 1992), the Tri-Party Agreement will allow continued storage of this waste until sufficient treatment capacity is available in accordance with the schedules in the agreement.

If additional variances, exemptions, or extensions of time are required as a result of delays in the development of treatment, storage, or disposal capacity, they will be applied for in accordance with the procedures detailed in the Tri-Party Agreement (Ecology et al. 1989). 


\subsection{SINGLE-SHELL TANK WASTE}

Single-she11 tank waste currently in storage is not a 1 and disposal restricted waste because it was placed in storage before the effective date of the land disposal restrictions for mixed waste (November 27, 1987).

Information on the single-shell tanks is included only because if the waste is retrieved or transferred, it then becomes a land disposal restricted waste and this information will be required to identify treatment and disposal capacity requirements.

Single-she11 tanks are underground, reinforced-concrete, steel-1ined tanks used for storage of waste. These tanks have held chemically hazardous and radioactive waste generated as a byproduct of processing spent nuclear fuel for the recovery of plutonium, uranium, and neptunium beginning in 1944; additional tanks were constructed as required.

Liquid waste collection and storage in the single-shell tanks continued until November 1980 . The only material added to the single-shell tanks since 1980 has been water, which was added to two tanks for evaporative cooling purposes. An interim stabilization program was initiated in 1968 to remove pumpable interstitial liquid and supernatant from the single-shell tanks and transfer it to the double-shell tanks. This program is primarily intended to reduce the leak potential of the single-shell tanks and will be completed in 1996 (WHC 1990c).

The single-shell tanks consist of 149 tanks containing approximately 140,000 cubic meters of waste. These tanks are located in 12 tank farms with 4 to 18 tanks each in the 200 East and 200 West Areas. The amount of waste contained in the tanks varies from 5\% to 95\% of each tank's capacity and varies in consistency from pumpable liquid to sludge to hard salt cake.

\subsubsection{Generation}

This section describes the waste generation process.

4.3.1.1 process. The waste has been generated through a variety of analytical, decladding, and separation processes and various associated sitewide operations. The single-shell tanks received this waste from various Hanford Site activities before 1980.

Waste currently stored in the single-shell tanks was produced by four major chemical processing operations that were conducted from 1944 to 1980:

- The bismuth phosphate process

- The reduction-oxidation process

- The PUREX process

- The tributyl phosphate process.

The bismuth phosphate, reduction-oxidation, and PUREX Plant processes were specifically designed for plutonium recovery. The initial bismuth phosphate chemical separations process produced large volumes of dilute, low-heat waste. The tributyl phosphate solvent extraction process was designed for the recovery of reiativeily iarge amounts of uranium that remained in the bismuth 
phosphate process waste. The bismuth phosphate process was superseded by the reduction-oxidation process, which was superseded by the PUREX process.

The reduction-oxidation and PUREX processes recovered the uranium and neptunium as well as the plutonium from the irradiated reactor fuel. The PUREX process used solvent extraction with tributyl phosphate to separate uranium and plutonium. Chemical removal of the fuel cladding before extriction prociuced decladding waste with high concentrations of aluminum and zirconium. High-heat-producing isotopes in the waste were separated from the fuel-reprocessing waste by a modified B Plant waste fractionation process. The strontium was separated by an extraction process using complexing agents (e.g., ethylene-diaminetetraacetic acid, n-hydroxyethylethylenediaminetetraacetir cid, citrate) to urevent transition metal extraction. The cesium was purifi by ion exchange. These isotopes (cesiun and strontium) were converted to fluoride and chloride salts and encapsulated in the Waste Encapsulation and Storage Facility. Sodium hydroxide or sodium carbonate was added to the waste before transfer to the single-shell tanks to create an alkaline solution and to minimize tank corrosion (DOE/RL 1989c). The processing of irradiated fuels produced waste that included most of the fission products and comparatively small quantities of uranium, plutonium, and other actinides (WHC 1990C).

Smaller volumes of waste also were added to the single-shell tanks from research and development programs, facility and equipment decontamination, iaboratory activities, and the Plutonium Finishing Plant (DOE/RL 1989C).

Waste components in the single-shell tanks have settled, stratified, and sogregated. The tanks contain a mixture of nonradioactive and radioactive chemicals produced during the various chemical processes. Therefore, the determination of the actual composition of each tank of waste is complex.

4.3.1.2 Generation. Addition of new waste into the single-shell tanks was terminated in November 1980. Water is occasionally added to certain tanks if necessary for evaporative cooling purposes. This water evaporates and does not add to the raste volume.

\subsubsection{Characterization}

The single-shell tanks contain radioactive mixed waste that is solid, liquid, and sludge. This waste is categorized as corrosive and TCLP Toxic.

This section discusses the available waste characterization information. Information based on process knowledge and sample analys is is provide along with the waste designatic is and their bases, the uncertainty related to the designation, and the schedule for further analysis.

4.3.2.1 Process Knowledge. The single-shell tanks coritair rradiated fuel reprocassing waste frum separation plants. The tanks receit: waste from five chemical process activities: the bismuth phosphate, reducric,-oxidation, PUREX, and tributyl phosphate prresses, and B Plant waste fractiunation.

The single-shell tanks contain approximateiy 140,000 cubic meters of waste as radionuclides and dangerous nonradioactive chemicals. The 
distribution of the three waste forms (sludge, salt cake, and supernatant) in these tanks is illustrated in Figur? 4-5 (WHC 1990a). The salt cake and sludge contain interstitial liquid. The bulk of this liquid, apprsyimately 19,000 cubic meters, is contained in salt cake and is being pumped to the double-shell tanks.

The sludge consists of the solids (hydrous metal oxides, iron, and aluminum) precipitated from the neutralization of acid waste before transfer to the single-shell tanks. Sludges vary greatly in their physical properties. Salt cake contains various salts, primarily sodium nitrate, formed by the evaporation of the water from the waste. Damp salt cake is a jelly-like material; dried salt cake is a hard, abrasive, brittle material that may have formed as large single crystals. The salt cake porosity ranges from 10-50\%. The liquid exists as supernate and interstitial fluid (WHC 1990C).

Additional equipment components also are found in the tanks with the process waste. These include metal measuring tapes, level instrumentation, other contaminated scrap, pump heads and shafts, and diatamaceous earth. other nonrecorded items are likely to be contained in the tanks.

4.3.2.2 Sample Analyses. Sample analyses are used to evaluate the chemical, physical, and radiological properties of the single-shell tank waste and soils that have been contaminated by spills and leaks. This determination will be used to select a disposal alternative that can be executed safely in compliance with RCRA, the Washington State Hazardous Waste Management Act, the National Environmental Policy Act, and the Atomic Energy Act regulatory requirements. The waste is extremely varied with respect to radionuclide content and chemical and physical characteristics. This variation among tanks is due to the different nuclear fuel processes and the blending, evaporation, and admixture schemes used since 1940.

A remotely operated method for obtaining samples was developed and implemented for sampling of the liquid and soft, solid tank waste. Orie to four core samples were removed from each of 15 single-shell tanks in fiscal year 1985 and 1986. Samples of the core were analyzed by the individual segment removed or as a homogenized sample of all segments retrieved from each core. The detailed waste analysis results are reported in Weiss (1986) and Adams et al. (1986).

The single-shell tank waste primarily is composed of sodium hydroxide; sodium salts of nitrate, nitrite, carbonate, aluminate, and phosphate; and hydrous oxides of iron and manganese. A relatively small amount of solvents was added to the single-shell tank waste during fuel reprocessing as well as water-soluble complexing agents and carboxylic acids from the B Plant waste fractionation process (DOE/RL 1989C). Initial estimates of inventories of nonradioactive chemicals are given in Table 4--5 (WHC 19900).

Twenty-two of the single-shell tanks contain cyanides, introduced as ferrocyanides in a process to precipitate cesium. Approximately $90 \%$ of the ferrocyanide is in 10 of the ianks. Mixtures of ferrocyanide with sodium nitrate or sodium nitrite may undergo explosive reactions when heated to temperatures significantly above current tank storage temperatures. The buildup of hydrogen under the salt cake in 17 of the single-shell tanks has been a concern. The potential for forming flammable or explosive gas mixtures 
in the tank vapor space or in gas pockets trapped below the surface of the waste must be considered in retrieval operations (RHO 1985).

A complete, long-term program to characterize single-shell tank waste is being conducted by the DOE. This program is detailed in Winters et al. (1989). Characterization of al1 149 single-shell tanks is scheduled to be completed by Septeriber 1998 according to the Tri-Party Agreement milestone $1,-10-00$. The concentration of chemical and radionuclide species of leaked or spilled materials will require future characterization. No sampling plan for these micterials has been developed.

4.3.2.3 Waste Designation and Basis. The waste in the single-shell tanks is considered ignitable (due to the presence of nitrate), corrosive, and TCLP toxic. The waste is assigned waste codes 0001 (ignitable), D002 (corrosive), D005 (TCLP toxic barium), D006 (TCLP toxic cadmium), D007 (TCLP toxic chromium), D008 (TCLP toxic lead), D009 (TCLP toxic mercury), D010 (TCLP toxic selenium), D011 (TCLP toxic silver), D019 (TCLP toxic carbon tetrachloride), and $\mathrm{FOOH}_{3}$ (acetone and hexone). These designatioris are based on process knowledge and limited sample analyses and may change subject to the results of the analysis and characterization of the waste. The waste designations will be reexamined as the tanks are characterized.

4.3.2.4 Uncertainty of Waste Designation. The confidence in the current waste code designations is low. The confidence will increase once necessary sampling and arialysis work is completed.

4.3.2.5 Schedule for Further Characterization. Characterization of the single-shell tank waste is scheduled to be completed in 1998, based on the current Waste Characterization Plan (Winters et al. 1989). This plan includes analysis for inorganic and organic materials and the hazardous waste characteristics and criteria (WAC-173-303).

\subsubsection{STORAGE}

This section describes the storage unit, provides the volume currently in storage and projected to be added, and assesses the compliance state of the storage unit.

4.3.3.1 Storage Unit and Capacity. Eighty-three of the single-shell tank tanks are located in the 200 West Area and 66 are located in the 200 East Area. The tanks are arranged in 12 tank farms. One hundred thirty-three of the tanks are 22.9 meters in diameter with nominal capacities between 2,000 and 3,800 cubic meters. Sixteen tanks are 6.1 meters in diameter with capacities of 210 cubic meters (WHC 1990C).

4.3.3.2 Amount in Storage. The single-shell tank waste consists of 140,000 cubic meters of solids including 25,000 cubic meters of interstitial liquid and supernatant. The volume of waste in each tank farm is shown in Figure :-6 (WHC 1990a). No waste has been added to the tanks since November 1980 or will be added to the tanks in the future. 
4.3.3.3 Storage Compliance Assessment. The single-shell tanks have released liquid to the soil columr. Table 4-6 details the current estimates of releases.

The single-shell tanks will be closed in accordance with schedules negotiated in the Tri-Party Agreement (Ecology et al. 1989). The singleshell tanks were reviewed for compliance with interim status dangerous waste regulations in accordance with milestone number M-21-00 (Ecology et al. 1989). Compliance action schedules and actions for limited compliance with the interim status requirements during the closure are being negotiated. The single-shell tanks were closed to the receipt of waste in 1980 .

Currently, the following interim status compliance actions are planned (DOE/RL 1990f):

- Develop waste analysis plans

- Develop contingency plans

- Deverop inspection plans

- Maintain inspection results in the operating record

- Determine if annual fire inspections are required

- Install 23 groundwater-monitoring wells by December 1991 (milestone M-24-00, Ecology et al. 1989).

A single-shell tank system closure/corrective action work plan was submitted in September 1989. Additionally, a supplemental Environmental Impact Statement will be prepared addressing single-shell tank closure before beginning final closure activities. Closure steps to be taken include removal of pumpable liquid from the tanks by September 1996.

\subsubsection{Treatment}

This section discusses the current and proposed waste treatment processes.

4.3.4.1 Current Treatment. Ninety-nine of the single-shell tanks have undergone interim stabilization by removal of pumpable liquid. The remaining tanks will undergo interim stabilization operations before disposal. An interim groundwater monitoring program has been established to comply with the interim status dangerous waste requirements found in WAC 173-303 and 40 CFR 265.

Fifty-nine of the 22.9-meter-diameter single-shell tanks and seven of the 6.1-meter-diameter single-shell tanks (WHC 1990c) are assumed to be leaking. Unique requirements for the retrieval of waste from the leaking single-sheli tanks have not been identified.

4.3.4.2 Proposed Treatment. The waste in the single-shell tanks will undergo. in situ disposal or a retrieval and disposal option. The selection of the 
treatment and/or disposal alternative will be documented through the National Environmental Policy Act process. In situ disposal options being considered include stabilization, grouting, and vitrification. Stabilization and in situ grouting would require closure of the tank farms as a mixed-waste landfill. Grouting reduces the hazard of the chemical waste in the tanks, but is unlikely to delist the waste. In situ vitrification may delist the waste chemically and may allow closure of the tank farms as a radioactive waste site. Both in situ disposal and waste retrieval are considered options for clean closure of the single-shell tanks and closure of the single-shell tanks as landfills, in compliance with the dangerous waste regulations.

Waste treated in the single-shell tanks will remain subject to the 1 and disposal restrictions unless the following criteria are met.

- Hazardous waste listings applicable to the waste must be identified, and the waste must be delisted in accordance with regulatory requirements.

- The treated waste must not exhibit a hazardous waste characteristic (corrosivity, ignitability, reactivity or TCLP toxicity).

- Treated waste must meet the treatment standards specified by 40 CFR 268.

Waste that meets these requirements would still be subject to the state RCRA program unless the waste does not exhibit any of the dangerous waste criteria for toxicity, persistence, or carcinogenicity of WAC 173-303-101 through 103.

\subsubsection{Minimization}

A waste evaporation program was initiated in 1965 to reduce the volume of liquid waste that potentially could leak and contaminate the soil surrounding the tanks. The supernatant liquids were extracted from the single-shell tanks, evaporated to a slurry, and replaced in the tanks for storage. In 1974 two evaporators were installed and used to evaporate approximately 510,000 cubic meters of water.

\subsubsection{Variances, Exemptions, Time Extensions}

The single-shell tank waste consists of radioactive waste mixed with dangerous waste constituents. The single-shell tank waste is not subject to land disposal restrictions until it is removed from the tanks because it was all generated and placed in storage before November 2\%, 1987 (the date when mixed waste became subject to RCRA).

The Tri-Party Agreement provides for development of treatment and disposal units for the single-shell tark waste as follows:

- Complete single-shell tank interim stabilization by September 1996

- Deveĩop single-shell tank waste retrieval technology and complete scale model testing by June 1994 


$$
\text { DOE/RL-90-41 }
$$

- Initiate full-scale tank demonstration of single-shell tank waste retrieval technology by October 1997

- Initiate full-scale farm closure demonstration project by June 2004

- Complete closut: of/all 149 single-shell tanks by June 2018.

If additional variances, exemptions, or extensions of time are required as a result of delays in the development of treatment, storage, or disposal capacity, they will be applied for in accordance with the procedures detailed in the Tri-Party Agreement (Ecology et a1. 1989).

Information on single-shell tanks waste is provided because of the applicability of land disposal restrictions to the waste upon retrieval and because of the need to consider single-shell tank waste in establishing treatment capacity requirements for tank waste.

\subsection{2-A EVAPORATOR PROCESS CONDENSATE}

The 242-A Evaporator concentrates the low-level Hanford Site waste that is stored and treated in underground double-shell tanks. The tanks store low-heat-generating waste that contains relatively small amounts of fission products.

The 242-A Evaporator concentrates liquid waste by evaporation and separates organic from inorganic waste constituents to facilitate further treatment. This process reduces the waste volume and, hence, the number of double-shell tanks required for storage. The 242-A Evaporator started operating in September 1977; ongoing upgrades will extend its useful life through the year 2000.

In the past (prior to 1989), the process condensate was routed to retention basins, analyzed for radionuclides and ammonia, and discharged to a crib. In April 1989, dangerous waste and high concentrations of ammonia were detected in the process condensate and discharge to the crib was discontinued. The 242-A Evaporator currently is not operating and is scheduled to restart in December $1990^{1}$. At this time, the process condensate will be discharged to the Liquid Effluent Retention Facility and ultimately treated for disposal at the Effluent Treatment Facility.

\subsubsection{Generation}

This section describes the waste generation process and estimates the generation rate.

4.4.1.1 Process. The 242-A Evaporator concentrates low-level liquid Hanford Site waste by evaporation. The evaporation process also separates the organic constituents and water from the inorganic constituents and radionuclides.

${ }^{1}$ This schedule date is currently being evaluated. 
The 242-A Evaporator receives a mixture of waste from tank 241-AW-102 that consists of processed and unprocessed waste as well as recycled liquid that is removed from storage tanks after solids have settled. A simplified schematic of 242-A Evaporator process operations is shown in Figure 4-7.

The 242-A Evaporator heats the feed, at reduced pressure, and evaporates off some of the water and the volatile organic constituents from the slurry. The vapor fraction and the slurry fraction are then processed separately. The vapor fraction is condensed, filtered, and discharged to Liquid Effluent Retention Facility as process condensate. If the process condensate does not meet discharge limits, it is pumped back to the 242-A Evaporator feed tank for processing. The remaining supersaturated slurry is recirculated. When the slurry is sufficiently concentrated, it is pumped to underground storage in double-shell tanks.

4.4.1.2 Generation. Upon restart in December 19901, the 242-A Evaporator will generate up to 4,500 cubic meters of process condensate per month until the Liquid Effluent Retention Facility (Section 4.4.3) is ful1. The 242-A Evaporator will then be shut down for a short time. The 242-A Evaporator wi11 restart when the Effluent Treatment Facility becomes operational (scheduled for October $1992^{2}$ ).

When the 242-A Evaporator restarts in October 1992l, it will increase its processing rate over a 4-month period until process condensate is being generated at a rate of 6,000 cubic meters per month or 72,000 cubic meters per year.

\subsubsection{Characterization}

The process condensate is a liquid low-level waste consisting of the condensed vapor fraction from the evaporation process and raw water. The process condensate is designated a dangerous waste because of toxicity (WT02) and the presence of spent nonhalogenated solvents acetone (F003) and methyl ethyl ketone (Hexone) (F005).

4.4.2.1 Process Knowledge. The 242-A Evaporator receives liquid waste from most of the Hanford Site waste generators and processes. This waste is processed through the 242-A Evaporator in different batches according to their classification by total organic carbon content, transuranic content, and effects on the evaporator process.

Dilute complexed waste is received from processing operations at B Plant. This waste contains high amounts of total organics and complexing agents.

Dilute noncomplexed waste is a mixture of $T$ Plant and S Plant waste, Plutonium Finishing Flant supernate, salt well liquids, 300 and 400 Area waste (including fuel fabrication waste), PUREX Plant neutralized decladding waste supernate, salt well liquids (Section 4.3), and ammonia scrubber waste (Section 4.6) (WHC 1990e).

This schedule date is currently being evaiuated.

2 This schedule date is currently being evaluated. 
4.4.2.2 Sample Analyses. Process condensate was sampled for characterization from August 1985 to March 1989, during the processing of a variety of

evaporator feeds. The average concentration of each analyte detected is shown in Table 4-7 (WHC 1990e).

4.4.2.3 Waste Designation and Basis. The process condensate is designated a dangerous waste because of toxicity (WTO2). Forty-seven substances potentially present in the process condensate were determined to have toxic categories associated with them. The contribution of each substance to the percent equivalent concentration was calculated per WAC 173-303-101. The resulting equivalent concentration sum is $10 \%$ higher than the limit of $0.001 \%$; therefore, the process condensate is a toxic dangerous waste. The dominant contributor to the equivalent concentration sum is ammonia.

Additionally, the process condensate is designated a dangerous waste because it is derived from waste that contains the spent nonhalogenated solvents acetone, hexone, and 1-butanol (F003) as well as methyl ethyl ketone and 2-butanone (FO05) (WHC 1990e).

4,4.2.4 Uncertainty of Waste Designation. The current designations are considered accurate.

4.4.2.5 Schedule for Further Characterization. The process condensate will be characterized after treatment (Section 4.4.4) to confirm that it is no longer designated dangerous.

\subsubsection{Storage}

The 242-A Evaporator currently is not operating and is being modernized. Process condensate, therefore, is not being generated and no process condensate currently is in storage. On restart of the 242-A Evaporator (projected to be December $1990^{1}$ ), process condensate will be stored at the Liquid Effluent Retention Facility until a treatment system is operational. The Liquid Effluent Retention Facility can hold about 49,000 cubic meters of process condensate, which is the volume projected to be generated between December 1990 and October 1991.

The Liquid Effluent Retention Facility is under construction and will be used to store process condensate generated by the 242-A Evaporator when it is restarted in December $1990^{1}$. The Liquid Effluent Retention Facility consists of surface impoundment storage units that will comply with both interim status and final status design and operation requirements. A Part B permit application is being prepared and will be submitted in June 1991 in accordance with Tri-Party Agreement milestone M-20-47 detailing the compliance of the Liquid Effluent Retention Facility with RCRA final status design and operation standards. All dangerous waste will be removed from the Liquid Effluent Retention Facility by June 1995 in accordance with the Tri-Party Agreement milestone M-26-04 (Ecology et a1. 1989).

IThis scheduie date is currently being evaluated. 


\subsubsection{Treatment}

Planned treatment of the process condensate stored at the Liquid Effluent Retention Facility is as follows. The Effiuent Treatment Facility will treat process condensate and prepare the waste for disposal. The current conceptual design is as follows:

- The first process step is to filter out particles down to the 0.5 -micron range. The $\mathrm{pH}$ of the waste.tream is then lowered to four or five by addition of sulfuric acid. This adjustment converts ammonia to ammonium, so that it will be rejected during reverse osmosis; converts carbonate and bicarbonate to carbon dioxide; and inhibits microbial growth.

- Next, an organic destruction unit uses hydrogen peroxide and/or ozone with ultraviolet light to degrade organic molecules into carbon dioxide and water. Ultrafiltration step removes particles in the 0.01 micron range.

- Degasification removes the carbon dioxide generated during neutralization. Then, reverse osmosis removes aqueous salts and metal ions, producing a secondary wastestream that will be further concentrated before disposal.

- The stream next undergoes ion exchange and is neutralized. Three tanks hold the treated effluent for sampling before discharge (current plans call discharge to a state-approved land disposal site) or recycling (if required). The treated liquid effluent will be delisted before discharge.

- An evaporation process further reduces the volume of waste generated in the primary treatment. The bottoms product is dewatered and stored in 0.21-cubic-meter drums. If the bottoms product is a dangerous waste, it will be sent to the Central Waste Complex and treated at the Waste Receiving and Processing Facility. If it is not dangerous, the drums will be disposed of at low-level waste burial grounds.

The Effluent Treatment Facility is scheduled to begin operations in October $1992^{2}$.

\subsubsection{Minimization}

Planned treatment of the process condensate will result in a nondangerous liquid stream acceptable for discharge to the ground and a solid waste form acceptable for land disposal.

The treatment unit will reduce each 245 cubic meters of process condensate to one 0.21 -cubic meter drum of solid waste; this is a waste reduction factor of 1,176 . This reduction is based on two assumptions: the

${ }^{2}$ This schedule date is currently being evaluated. 
average concentration of ammonium in process condensate is 410 parts per million and the waste product in the drums is $100 \%$ ammonium sulfate.

\subsubsection{Variances, Exemptions, Time Extensions}

The 242-A Evaporator process condensate is a low-level mixed waste that is land disposal restricted because it contains solvent list (40 CFR 268.30) constituents. Currently, process condensate is not generated because the 242-A Evaporator is shut down for modifications. Additional process condensate generation is scheduled for December 1990I, when the 242-A Evaporator is restarted.

The Tri-Party Agreement (Ecology et al. 1989) provides for continued storage of solvent waste ( 40 CFR 268.30) until treatment capacity is developed for these wastes. The agreement requires treatment and disposal capacity for this waste to be developed on the following schedule:

- Construction and initiation of the Liquid Effluent Retention Facility operation by December 1990

- Cessation of discharge of process condensate to the Liquid Effluent Retention Facility by December 1994

- Removal of all dangerou's waste residues from the Liquid Effluent Retention Facility by June 1995.

Future process condensate generated will be discharged to and stored in the Liquid Effluent Retention Facility until the Effluent Treatment Facility is constructed and operational in June 1993. The Effluent Treatment Facility will treat process condensate to meet the land disposal restrictions. Additionally, a petition is being prepared to delist the effluent from the Effluent Treatment Facility to allow land disposal of the treatment residues.

Part B permit applications will be submitted for the 242-A Evaporator, the Liquid Effluent Retention Facility, and the Effluent Treatment Facility in June 1993 or as agreed to by DOE, EPA, and Ecology. The delisting petition for the Effluent Treatment Facility will be submitted at least 18 months before facility startup.

If additional variances, exemptions, or extensions of time are required because of delays in the development of treatment, storage, or disposal capacity, they will be applied for in accordance with the procedures detailed in the Tri-Party Agreement (Ecology et al. 1989).

\subsection{SODIUM STORAGE FACILITY WASTE}

The 4843 Sodium Storage Facility Waste receives radioactive and nonradioactive alkali metal waste from Hanford Site generators. The predominant generator of alkali metal waste is the Fast Flux Test Facility.

${ }^{1}$ This schedule date is currently being evaluated. 
Most of the waste received at the 4843 Sodium Storage Facility Waste consists of alkali metals and retired equipment from liquid sodium processes. The bulk of material presently in storage is sodium derived from riormal Fast Flux Test Facility operations and a pump leak at the Fast Flux Test Facility.

The waste stored in the 4843 Sodium Storage Facility Waste currently is untreated. The preferred disposal option involves converting the sodium to sodium hydroxide then to sodium carbonate. The sodium carbonate would be designated and disposed of in accordance with applicable regulations.

The current inventory of the 4843 Sodium Storage Facility Waste includes approximately $550 \mathrm{kilograms}$ of radioactive sodium, a few kilograms of nonradioactive Tithium, sodium-contaminated piping and tanks, and miscellaneous experimental apparatus. The continued operation of the 4843 Sodium Storage Facility currently is being studied by the Westinghouse Hanford Company, pending results of this study, the facility will continue to operate. If it is decided to close the facility the waste will be transferred to the Central Waste Complex prior to facility closure. Results of this study will be discussed in the annual report (milestone M-26-02, Ecology et al. 1989).

\subsubsection{Generation}

This section discusses the waste generation process and rate.

4.5.1.1 Process. The Fast Flux Test Facility is an experimental reactor that uses liquid sodium in the primary coolant loop. One cubic meter of sodium and 0.5 cubic meter of structural and other equipment were generated by a pump leak at the Fast Flux Test Facility.

Seven drums of waste radioactive sodium have been generated at the Fast Flux Test Facility as a result of normal operations over the past ten years. The rate of future waste production is anticipated to decrease, due to a modification in the Fast Flux Test Facility procedures that permits recycling of some of this material.

\subsubsection{Generation. The 4843 Sodium Storage Facility Waste became} operational in September 1987 to receive radioactive and nonradioactive alkali metal waste from Hanford Site generators. Most of the waste received at the 4843 Sodium Storage Facility Waste consists of spill residue and retired equipment from liquid sodium processes at the Fast flux Test Facility.

\subsubsection{Characterization}

This section discusses the available waste characterization information. Information based on process knowledge and sample analysis is provided along with the waste designation and basis. The uncertainty related to the designation and the schedule for further analysis also are discussed.

4.5.2.1 Process Knowledge. All material in the 4843 Sodium Storage Facility Waste is solid, low-level radioactive waste. All of the of waste sodium in the storage unit has been generated at the fast fiux Test facilitiy from normai operations, a pump leak, and miscellaneous experimental apparatus. 
4.5.2.2 Sample Analyses. The waste in the 4843 Sodium Storage Facility Waste is characterized based on process knowledge that is considered adequate to manage the waste properly. No analysis is considered necessary at this time.

4.5.2.3 Waste Designation and Basis. The alkali metal waste received for storage at the 4843 Sodium Storage Facility Waste is characterized as reactive (D003).

4.5.2.4 Uncertainty of Waste Designation. The waste characterization certainty is considered high, based on derivation of the waste from sodium cooling loops and experimental apparatus.

4.5.2.5 Schedule for Further Characterization. No further characterization of the waste stored in the 4843 Sodium Storage Facility Waste is anticipated. During the treatment processes the treatment residues will be analyzed chemically to verify completeness of treatment and to designate the waste for proper disposal.

\subsubsection{Storage}

This section describes the storage unit, provides the amount in storage, and assesses the compliance status of the unit.

4.5.3.1 Description of Storage Unit and Capacity. The 4843 Sodium Storage Facility Waste storage unit is located in the northwest corner of the 400 Area of the Hanford Site. There are no other buildings in the immediate vicinity of the 4843 Sodium Storage Facility Waste. The gravel area surrounding the building is clear of combustibles for several hundred meters. The building is 12 meters long, 12 meters wide, and 6 meters high. The building has an al1steel structural frame and sides and a gable roof, all of which are insulated with fiberglass batting. The floor is a concrete slab. Building access is through two large roll-up doors in the east and west ends and through personnel doors in the southeast and northwest corners.

The 4843 Sodium Storage Facility Waste is used to store radioactive and nonradioactive alkali metal waste, including sodium, lithium, and a sodium/potassium mixture, which has been generated at the Fast Flux Test Facility and other operations at the Hanford Site that use alkali metals. Waste is segregated within the building depending on whether the alkali metal is radioactiva or nonradioactive. Radioactive alkali metal waste is stored in $0.71-c u b i c$ meter drums, various piping sections, and 'hot-traps'. Nonradioactive alkali metal waste is stored in the southern half of the building. The radioactive and nonradioactive storage areas are separated by rope divider.

The 4843 Sodium Storage Facility Waste only accepts solid alkali metal waste properly packaged in U.S. Department of Transportation-specified containers. To keep the reactive alkali metal waste stable, these containers are flushed with inert gas (argon) and sealed to provide a nonractive atmosphere.

The Estimated capacitiy of the 4843 Sodium Storage Faciility Waste is 84,000 kilograms of alkali metal (DOE/RL 1989b). 


$$
\text { DOE/RL-90-41 }
$$

4.5.3.2 Amount in Storage. The current inventory of the 4843 Sodium Storage Facility includes approximately 550 kilograms of radioactive sodium, a few kilograms of "ionradioactive $1 i$ thium, sodium-contaminated piping and tanks as well as miscellaneous experimental apparatus.

\subsubsection{Storage Compliance Assessment. The 4843 Sodium Storage Facility} Waste was reviewed for compliance with interim status dangerous waste regulations in accordance with the Tri-Party Agreement milestone M-21-00 (Ecology et a1. 1989). No areas of noncompliance with interim status requirements were noted. A Part B permit application is being prepared and will be submitted in March 1991 detailing compliance with the final facility design and operating regulations.

\subsubsection{Treatment}

This section discusses the current and proposed waste treatment.

4.5.4.1 Current Treatment. The 4843 Sodium Storage Facility Waste is a storage unit. The waste stored in this unit is not currently being treated.

4.5.4.2 Proposed Treatment. The proposed treatment for the sodium waste stored in the 4843 Sodium Storage Facility Waste is described in the Fast Flux Test Facility Shutdown Action Description Memorandum. Treatment will be accomplished in the existing Maintenance and Storage Facility, following modification and upgrading. In addition, other offsite treatment options are being studied for nonradioactive sodium waste.

The treatment process has been designed to accommodate approximately 772,000 kilograms of radioactive sodium produced by the proposed shutdown of the Fast Flux Test Facility. Sodium will be converted to a $50 \%$ sodium hydroxide water solution in a reaction vessel, followed by conversion of the sodium hydroxide to sodium carbonate by reacting the sodium hydroxide solution with carbon dioxide in an evaporator. The end product of the conversion process is a solid, dry, nonhazardous radioactive material in a form ready for land disposal as low-level waste.

Modifications of the process may be required to accommodate specific characteristics of some of the sodium waste in the 4843 Sodium Storage Facility Waste. Design work to support Maintenance and Storage Facility modifications tentatively is scheduled for fiscal year 1991, contingent on the Fast Flux Test Facility shutdown decision.

\subsubsection{Minimization}

This section discusses current and proposed waste minimization practices.

4.5.5.1 Current Waste Minimization Practices. The 4843 Sodium Stoidge Facility Waste is a storage unit that receives alkali metal waste generated on the Hanford Site. The 4843 Sodium Storage Facility Waste does not exercise direct control over the quantities accepted for storage. Waste generated at the 4843 Sodium Storage facilitiy Haste, although minifinal, is managed to ensure that the quantity and toxicity are minimized. 
The 4843 Sodium Storage Facility Waste has an operating procedure for the disposal of waste generated at the 4843 Sodium Storage Facility Waste, that includes proper responses for cleanup after dangerous waste spills. The response to dangerous waste spills is aimed at minimizing liquid and material used during cleanup.

4.5.5.2 Proposed Waste Minimization Practices. No changes to the current waste minimization practices are proposed before treatment. Conversion to carbonate will remove the entire inventory of elemental sodium waste.

\subsubsection{Variances, Exemptions, Time Extensions}

The 4843 Sodium Storage Facility stores low-level mixed waste. That is restricted from land disposal by the Third Third Promulgation (55 FR 22520). Removal and treatment of the 4843 Sodium Storage Facility waste to meet 1 and disposal restriction requirements is planned as part of the closure activities for the Fast Flux Test Facility.

The Third Third Promulgation (55 FR 22520) provided for a 2-year national capacity variance from the land disposal restrictions for Third Third mixed waste. This variance allows continued storage of these wastes. In the event that sufficient treatment capacity for this waste is not available at the expiration of this variance (August 1992), the Tri-Party Agreement will allow continued storage of this waste until sufficient treatment capacity is available in accordance with the schedules in the agreement.

If additional variances, exemptions, or extensions of time are required as a result of delays in the development of treatment, storage, or disposal capacity, they will be applied for in accordance with the procedures detailed in the Tri-Party Agreement (Ecology et a1. 1989).

\subsection{PUREX AMMONIA SCRUBBER WASTE}

The ammonia scrubber waste is a low-level mixed waste liquid effluent generated by the PUREX Plant. During the PUREX Plant operations, approximately 7,600 cubic meters of ammonia scrubber feed are generated per year. The most recent fraction of ammonia scrubber feed was treated with sodium hydroxide in preparation for tank storage. The resulting ammonia scrubber waste is designated as corrosive (D002) as well as toxic (WT02) and is a land disposal restricted waste. Current plans for any future operations are to use an ammonia destruction process and, hence, significantly reduce the volume of dangerous waste generated by the ammonia scrubber system. However, the PUREX Plant is being placed in a standby condition and other plant configurations and upgrades for handling the ammonia scrubber feed may be considered during the standby period.

\subsubsection{Generation}

This section describes the waste geniration process. If the PUREX Plant restarts, estimates of the future waste generation wil? ie providuded after the PUREX Plant restart plans have been developed. 
4.6.1.1 Process. The PUREX Plant receives irradiated zirconium clad fuel from $N$ Reactor, removes the cladding from the fuel and dissolves the fuel in nitric acid. The dissolved fuel is processed through several solvent extraction steps to separate the plutonium, uranium, and neptunium from the fission products contained in the fuel. The PUREX ammonia scrubber feed is generated when water is sprayed to adsorb ammonia gas generated by the decladding and metathesis reactions from the dissolver off-gas stream.

In the past, the ammonia scrubber feed was boiled in a concentrator to separate the bulk of the entrained fission products from the ammonia scrubber discharge which was disposed of to a crib. The remaining ammonia scrubber waste was treated to comply with double-shell tank storage specifications and transferred to double-shell tanks as shown in Figure 4-8.

In 1ate 1987, it was determined that the ammonium hydroxide concentration in the ammonia scrubber condensate sometimes exceeded $1 \%$, making it a dangerous (toxic) waste as designated by state regulations, and therefore not appropriate for discharge to the crib. An interim process was established in which ammonia scrubber feed was no longer concentrated for discharge, but was treated for tank storage and transferred as ammonia scrubber waste to underground storage tanks. The treatment consisted of adding sodium hydroxide to adjust the $\mathrm{pH}$ to greater than 12 and adding sodium nitrite to minimize tank corrosion as shown in Figure 4-9.

Current plans for processing the future ammonia scrubber feed stream include ammonia destruction so that a significant portion of the stream will no longer be designated a dangerous or hazardous waste, as shown in Figure 4-10. This treatment system is scheduled to be completed in 1991. The need for completion of this system will be evaluated.

\subsubsection{Generation. Approximately 15 cubic meters of ammonia scrubber feed} is generated per metric ton of uranium processed. The amount of ammonia scrubber waste generated by month since January 1988 is shown in Figure 4-11.

The planned ammonia destruction system (Section 4.6.5) is expected to reduce the generation rate of land disposal restricted waste by this process from 15 cubic meters per metric ton of uranium processed to 2 cubic meters per metric ton of uranium processed. If the PUREX Plant restarts, the projected yearly generation of PUREX ammonia scrubber waste will be determined after the PUREX Plant restart plans have been developed.

\subsubsection{Characterization}

This section discusses the available waste characterization information. Information based on process knowledge and sample analyses is provided along with the waste designation and its basis, the uncertainty related to the designation, and the schedule for further analysis.

4.6.2.1 Process Knowledge. The ammonia scrubber feed wastestream is made up of water, ammonium hydroxide, dissolved ammonia, trace amounts of radionuclides, and fluoride and nitrate ions from the ammonium fluorideammonium nitrate solution used in the dissolver. The $\mathrm{pH}$ of the ammonia 


$$
\mathrm{DOE} / \mathrm{RL}-90-41
$$

scrubber feed stream before treatment for tank storage is between 8 and 10 . In the past, the ammonia scrubber waste was similar in composition to the ammonia scrubber feed except that $99 \%$ of the ammonia present in the ammonia scrubber feed was removed by volatilization during waste concentration and was discarded into the ammonia off-gas system or with the ammonia scrubber condensate wastestream.

4.6.2.2 Sample Analyses. The management of the PUREX ammonia scrubber waste can be divided as follows:

- The ammonia scrubber feed produced before late 1987, most of which was evaporated, condensed, and discharged to cribs as ammonia scrubber discharge (Figure 4-8)

- The total ammonia scrubber feed generated after crib closure in 1987, which was then treated and sent as ammonia scrubber waste to doubleshell tanks for storage (Figure 4-9).

The ammonia scrubber discharge was sampled randomly four times over a 23-month period during routine operation, once in 1985 and three times in 1987. The number of chemical analytes detected was 12, al though not every analyte was detected at each sampling time. Table 4-8 summarizes the analytical results (WHC 1990f).

The ammonia scrubber feed stored in the double-shell tanks is treated with sodium hydroxide and sodium nitrite. Available analytical data for this stream is shown in Table 4-9.

4.6.2.3 Waste Designation and Basis. Both the historical and PUREX ammonia scrubber wastestreams are toxic liquid, noncombustible low-level wastes classified as wastewaters.

The ammonia scrubber feed stream treated and sent to tank storage is toxic because of the concentration of ammonia. Pursuant to WAC 173-303-070, its designation is WT02. Treating the ammonia scrubber feed with sodium hydroxide, to raise the $\mathrm{pH}$ above 12 , occasionally renders the resulting ammonia scrubber waste corrosive (D002) as well and creates an 1 and disposal restricted waste. Future ammonia scrubber waste may still be corrosive but will be generated in small volume (WHC 1990f).

4.6.2.4 Uncertainty of Waste Designation. Waste designations for the ammonia scrubber waste recently sent to tank storage are based on sample analyses. Actual sample results show that the ammonia concentration exceeds 1 weight percent during the first few hours of the decladding reaction. The dangerous waste designation due to ammonia for these streams is only a result of exceeding the 1 weight percent limit for a few hours during each decladding reaction. The average concentration for ammonium in this waste is less than $0.1 \mathrm{M}$ as shown in Table 4-9.

Based on the chemicals adjed to the ammonia scrubber waste that was sent to double-shell tanks and on sample analyses, the ammonia scrubber waste is a toxic (WT02) and may be a corrosive (D002) land disposal restricted waste. 
4.6.2.5 Schedule for Further Characterization. The ammonia scrubber waste currently stored in tanks, together with any future ammonia destruction waste to be stored in tanks, will be characterized before planned treatment and disposal of the tank contents. The tank contents will be concentrated at the 242-A Evaporator to reduce the volume of waste requiring grout disposal. The streams ultimately will be disposed of by grout processing. The identification of additional waste characterization tasks will be negotiated among Ecology, the EPA, and the DOE (WHC 1990f).

\subsubsection{Storage}

This section provides the volume currently in storage and assesses the compliance state of the storage unit.

4.6.3.1 Storage Unit and Capacity. The PUREX ammonia scrubber waste is stored in underground double-shell tanks in the 200 East Area of the Hanford Site. The tank farms have twenty-eight 4,300 cubic meters tanks, twenty-six of which are used to store nonaging waste. The total contents of the doubleshell tanks are addressed as a single wastestream in Section 4.1.

4.6.3.2 Amount in Storage. The amount of double-shell tank waste in storage contributed by ammonia scrubber waste is 5,900 cubic meters. The volume of waste requiring disposal as grout will decrease when the waste is evaporated before grout disposal. The capacity of the tank farms for continued waste storage is discussed in Section 4.1.

4.6.3.3 Storage Compliance Assessment. The PUREX ammonia scrubber waste is stored in the double-shell tanks. The double-shell tanks were reviewed for compliance with interim status dangerous waste regulations in accordance with the Tri-Party Agreement milestone number M-21-00 (Ecology et a1. 1989). The results of the compliance assessment are provided in Section 4.1.3.3.

\subsubsection{Treatment}

This section discusses the ammonia scrubber waste current and proposed waste treatment processes.

4.6.4.1 Current ireatment. The ammonia scrubber waste has been treated for storage by adding sodium hydroxide and sodium nitrite to control tank corrosivity. The stream in the double-shell tanks will be concentrated at the 242-A Evaporator and disposed of at the Grout Treatment Facility.

4.6.4.2 Proposed Treatment. In the current plans, the ammonia in the ammonia scrubber feed will be destroyed by the addition of nitrite. The process will consist of five steps: neutraiize ammonia scrubber effluent; concentrate neutralized effluent; destroy the ammonia; adjust $\mathrm{pH}$ and nitrite; and transfer to tank storage (WHC 1990f). Figure 4-10 includes a schematic of this process.

The first step, neutralization of the effluent from the ammonia scrubbers, will be accomplished by adding nitric acid. The second step is concentrating the neutralized effluent produced by the first step. The 
concentration process will produce a nonhazardous, nondangerous stream that is primarily water. This stream will go to the Liquid Effluent Treatment

Facility for storage and to the Effluent Treatment Facility for treatment and disposal. This facility is described in Section 4.4.4.

The third step will be destroying the ammonia by reaction with sodium nitrite. The nitrite ions will react at elevated temperature with the ammonium ions in the concentrated neutralized effluent to produce water and nitrogen gas. The nitrite ions will react to become nitrate ions, accounting for most of the dissolved solids content of the resulting radioactive liquid waste.

The fourth step will be $\mathrm{pH}$ and nitrite adjusiment. Sodium hydroxide will be added to raise the $\mathrm{pH}$ of the liquid above 12, and additional sodium nitrite will be added, if necessary, to minimize corrosion in the double-shell tanks.

This entire treatment system (milestone M-17-02, Ecology et a1. 1989) is scheduled to be completed by 1995, but this date will be evaluated.

\subsubsection{Minimization}

Currently, 15 cubic meters of ammonia scrubber feed is generated and stored in tanks for every metric ton of uranium processed. In the future, the volume of ammonia scrubber waste would be minimized by the use of an ammonia destruction process, producing a final volume of only 2 cubic meters of ammonia destruction waste per metric ton of uranium processed (WHC 1990d).

Second, the current and any future ammonia scrubber waste that is stored in tanks will be evaporated with other double-shell tank waste to reduce the volume requiring disposal at the Grout Treatment Facility (Section 4.1).

\subsubsection{Variances, Exemptions, and Time Extensions}

The ammonia scrubber waste is a low-level mixed waste which is restricted from 1 and disposal by the Third Third Promulgation (55 FR 22520). The Third Third Promulgation (55 FR 22520) provided for a 2-year national capacity variance from the 1 and disposal restrictions for Third Third mixed waste. This variance allows continued storage of these wastes. In the event that sufficient treatment capacity for this waste is not available at the expiration of this variance (August 1992), the Tri-Party Agreement will allow continued storage of this waste until sufficient treatment capacity is available in accordance with the schedules in the agreement.

If additional variances, exemptions, or extensions of time are required as a result of delays in the development of treatment, storage, or disposal capacity, they will be applied for in accordance with the procedures detailed in the Tri-Party Agreement (Ecology et al. 1989). 


\subsection{PUREX PROCESS CONDENSATE}

The PUREX process condensate is a low-level mixed waste liquid effluent generated by the PUREX Plant. As of April 1, 1990, approximately 4,800 cubic meters of PUREX process condensate have been generated and are stored in double-shell tanks.

The PUREX process condensate is distilled water with a nitric acid content that can exceed $0.01 \mathrm{M}$ ( $\mathrm{pH} 2$ ). Additionally, the stream contains various radionuclides. Until 1987, the PUREX process condensate stream was discharged directly to a crib. After closure of the crib and to prevent corrosive ( $\mathrm{pH}<2$ ) waste from being discharged into the new crib, potassium hydroxide was added and the stream was routed through a tank with calcium carbonate (1imestone) before being discharged. In early 1989 the stream was temporarily rerouted to double-shell tanks during a reevaluation of its dangerous waste designation. The PUREX process condensate transferred to double-shell tanks was designated corrosive (D002).

\subsubsection{Generation}

This section describes the waste generation process. If the PUREX Plant is the preferred option for the disposition of stored reactor fuel, estimates of the future generation rate will be provided after the PUREX PIant restart plans have been developed.

4.7.1.1 Process. The PUREX PIant receives irradiated zirconium clad fuel $\mathrm{N}$ Reactor, removes the cladding from the fuel and dissolves the fuel in nitric acid. The dissolved fuel is processed through several solvent extraction steps to separate the plutonium, uranium, and neptunium from the fission products contained in the fuel.

The PUREX process condensate stream is generated by the condensing of vapors from uranium/nitric acid concentration and recycle processes within PUREX. This condensate contains trace quantities of nitric acid. Before 1987, the condensate was monitored for radioactivity and discharged to a crib. In 1987, the PUREX process condensate system was upgraded to include a potassium hydroxide neutralization system and a calcium carbonate neutralization bed to neutralize the traces of nitric acid in the PUREX process condensate before discharge to a second crib (Figure 4-12).

In 1989, during a reevaluation of the designation of the PUREX process condensate stream to ensure that no improperly designated waste was being discharged to the environment, the PUREX process condensate wastestream was treated to meet tank storage specifications and transferred to the doubleshell tanks (Figure 4-13).

Current plans for future operations are to neutralize and treat the PUREX process condensate wastestream (Figure 4-14), but these plans will be evaluated.

4.7.1.2 Generation. Approximately 44 cubic meters of PUREX process condensate is generated per metric ton of uranium processed. 
DOE/RL-90-41

\subsubsection{Characterization}

This section discusses the available waste characterization information. The information is gathered from process knowledge and sample analyses data. Preliminary waste designation and basis, the uncertainty related to the designation and the schedule for further analys is is provided.

4.7.2.1 Process Knowledge. Before 1986, the traces of nitric acid that distilled over with the PUREX process condensate were not neutralized before discharging that stiream to a crib. After 1986, a neutralization system was installed that included controlled addition of potassium hydroxide to the PUREX process condensate, a pH polishing tank containing calcium carbonate (crushed limestone), and pH monitoring instrumentation (Figure 4-12) (WHC 19901).

4.7.2.2 Sample Analysis. During PUREX operations, PUREX process condensate is sampled and as indicated below.

- Pre-1989 - PUREX process condensate was sampled with a weekly composite sampler system. Samples were collected in a tank over a one-week time period and analyzed for key radionuclides, pH, organics, and uranium.

- 1989-1990 Stabilization Run - PUREX process condensate was batch sampled for $\mathrm{pH}, \mathrm{NO}_{2}$, and uranium and sent to double-shell tanks.

- If the PUREX Plant is restarted, future PUREX process condensate will be sampled with a RCRA-qualified composite sampler system. Samples will be collected over a one-week time period and will be sent to the laboratory to analyze for key radionuclides, $\mathrm{pH}$, organics, and uranium.

Before 1989, samples of the PUREX process condensate stream going to the crib were analyzed. The PUREX process condensate was randomly sampled eight times over a 24-month period during routine operations, once in 1985, twice in 1986 , and five times in 1987. The number of chemical constituents detected was 46, although not every constituent was detected in each samp?e. Table 4-10 summarizes the analytical results (WHC 19901).

4.7.2.3 Waste Designation and Basis. Before 1987, the PUREX process condensate wastestream occasionally was corrosive (pH less than 2), due to the nitric acid present in the PUREX process condensate. Under these conditions, the occasionally corrosive stream would have been designated as a corrosive (D002). After the neutralization system was installed in 1987, the PUREX process condensate stream was nondangerous. During a reassessment of the designation of the PUREX process condensate wastestream to ensure that no discharge to the environment of improperly designated waste was occurring, the PUREX process condensate was rerouted to double-shell tanks in early 1989 . The PUREX process condensate wastestream sent to the double-shel1 tanks was treated with sodium hydroxide (to adjust $\mathrm{pH}$ to above 12) and sodium nitrite (to control tank corrosivity). This treated waste was designated corrosive D002 (Figure 4-13). 


$$
\text { DOE/RL-90-41 }
$$

If the PUREX Plant is restarted, future plans include operation of a neutralization system to adjust the PUREX process condensate $\mathrm{pH}$ above 2 without closely approaching 12.5. Upon activation of this system, PUREX process condensate will be discharged as nondangerous waste (Figure 4-14).

4.7.2.4 Uncertainty of Waste Designation. The PUREX process condensate stream designation is based on process knowledge and sample analyses that are representative of the normal process. There are potential upset conditions and unusual occurrences that could create a corrosive dangerous waste. However, no unusual or abnormal events have occurred that would change the waste designation for the waste sent to double-shell tanks.

4.7.2.5 Schedule for Further Characterization. Future characterization of PUREX process condensate is discussed in Section 4.7.2.2.

\subsubsection{Storage}

This section discusses the PUREX process condensate waste storage and capacity, identifies stored quantities, and assesses the compliance status of the storage unit.

4.7.3.1 Storage Unit and Capacity. The PUREX process condensate waste is stored in underground double-shell tanks in the 200 East Area of the Hanford Site. These tanks are discussed in Section 4.1.

4.7.3.2 Amount in Storage. As of April 1, 1990, approximately 4,800 cubic meters of PUREX process condensate waste were in storage in the double-shell tanks.

4.7.3.3 Storage Compliance Assessment. The previously generated PÜREX process condensate is stored in the double-shell tanks. The double-shell tanks were reviewed for compliance with interim status dangerous waste regulations in accordance with the Tri-Party Agreement milestone number M-2100 (Ecology et al. 1989). The results of the compliance assessment are provided in Section 4.1.3.3.

If the PUREX PIant is restarts, future PUREX process condensate will not be a dangerous waste.

\subsubsection{Treatment}

This section discusses the PUREX process condensate current and proposed waste treatment processes.

4.7.4.1 Current Treatment. The PUREX process condensate has been treated for storage by adding sodium hydroxide and sodium nitrite to control tank corrosivity.

4.7.4.2 Proposed Treatment. Current plans call for elimination of the sodium hydroxide and sodium nitrite additions and operation of a continuous neutralization system to adjust the PUREX process condensate wastestream $\mathrm{pH}$ to greater than 2 and less than 1\%.5. The system will include in-line pH 
monitors providing input to automatic controllers that add potassium hydroxide as necessary to maintain a nondangerous wastestream (Figure 4-14). This

stream will be treated further at the Effluent Treatment Facility described in Section 4.4. These plans will be evaluated based on a PUREX restart decision.

\subsubsection{Minimization}

The waste minimization practices for the PUREX process condensate stream are to control the $\mathrm{pH}$ of the stream such that it is no longer a dangerous waste. This would eliminate the generation of a dangerous wastestream.

\subsubsection{Variances, Exemptions, Time Extensions}

As discussed in Section 4.7.4.2, the PUREX process condensate stream will not be generated with dangerous waste constituent concentration levels in the future, if the PUREX Plant is restarted. Previously generated PUREX process condensate waste was restricted from land disposal by the Third Third Promulgation (55 FR 22520). As a cr mponent of the double-shell tanks contents, PUREX process condensate $1 . " 1$ be treated and disposed of in accordance with the plans for double-shell tank low-level waste discussed in Section 4.1.6.

The Third Third Promulgation (55 FR 22520) provided for a 2-year national capacity variance from the 1 and disposal restrictions for mixed waste. This variance allows continued storage of these wastes. In the event that sufficient treatment capacity for this waste is not available at the expiration of this variance (August 1992), the Tri-Party Agreement will allow continued storage of this waste until sufficient treatment capacity is available in accordance with the schedules in the agreement.

If additional variances, exemptions, or extensions of time are required as a result of delays in the development of treatment, storage, or disposal capacity, they will be applied for in accordance with the procedures detailed in the Tri-Party Agreement (Ecology et al. 1989).

\subsection{HEXONE WASTE}

One hundred thirty-six cubic meters of liquid low-level waste, primarily hexone, is being stored in two underground tanks near the 202-S Plant in the 200 West Area. The waste currently is being distilled to remove radionuclides and then will be incinerated to destroy the hexone. Hexone waste no longer is being generated.

\subsubsection{Generation}

This section describes the waste generation process.

4.8.1.1 Process. The 202-S Plant used solvent extraction with hexone to separate uranium and plutonium from reactor fuel. The 202-S Plant operated from 1951 to 1967 (DOÉ 1987). 
4.8.1.2 Generation. The hexone is stored in two underground tanks. Tank 276-S-141 contains 76 cubic meters of hexone that never was used. Tank 276S-142 contains 53 cubic meters of mixed solvents and 8 cubic meters of water. The mixed solvents are $65 \%$ hexone, $25 \% \mathrm{~N}$-alkanes (normal paraffin hydrocarbon), and $9 \%$ tri-butyl phosphate that were added to the tank as spent solvent from a one-time americium extraction campaign at the 202-S Plant. Tank 276-S-142 also contains 8 cubic meters of water, most of which was added to the tank to flush transfer piping. The tanks also contain about 0.4 cubic meters of sludge, primarily tank corrosion products.

The hexone waste no longer is being generated.

\subsubsection{Characterization}

The hexone (methyl isobutyl ketone) waste is a dangerous liquid lowlevel waste. The dangerous waste codes for this material are $\mathrm{FOO}_{3}$ (hexone), WT02 (toxic dangerous waste), and D001 (ignitable). The result of a chemical analysis for each tank is shown in Table 4-11. The sampling and analyses were performed in 1987.

The hexone waste is a spent solvent that has been slightly contaminated with line flush, liquid, and corrosion products. The designations are considered accurate and no furt!.er characterization is planned until the hexone waste is treated for disposal (incinerated). At that time (1991), the treatment residue (incinerator ash) will be sampled and characterized by the operator of the incinerator to determine whether additional treatment is required before disposal.

\subsubsection{Storage}

This section discusses the hexone siorage unit and its capacity, provides the volume currently in storage, and assesses the compliance status of the storage unit.

4.8.3.1 Storage Unit and Capacity. The hexone waste is stored in two 89-cubic-meter carbon-steel underground storage tanks. The tanks are located west of the 202-S Plant in the 200 West Area.

4.8.3.2 Amount in Storage. Tank 276-S-141 contains 76 cubic meters of hexone; tank 276-S-142 contains 53 cubic meters of mixed solvents (mostly hexone), 8 cubic meters of water, and about 0.4 cubic meters of siudge, primarily tank corrosion products. No hexone waste is being added to these tanks because hexcne waste no longer is being generated.

4.8.3.3 Storage Compliance Assessment. A treatment and storage closure plan detailing compliance with regulations will be submitted in November 1992 . The tanks currently are being closed under interim status. 


\subsubsection{Treatment}

Currently (1990), the waste is being treated by distillation to remove radionuclides to allow disposal of the bulk of the waste as nonradioactive. The next treatment step will be incineration to destroy the hexone. This treatment is being conducted under interim status.

Hexone waste will be incinerated at an offsite location to reduce the hexone to harmless nonradioactive carbon dioxide and water. A flowsheet summarizing the planned treatment and disposal of hexone waste is shown in Figure 4-15. The treatment of hexone waste is scheduled to be completed by 1991 .

Distillation of the liquid waste will produce three primary product streams: the "clean" distillate, the tar-like bottoms in the distillation vessel, and the offigases of the distillation. The distillate vill be stored for further processing (offsite incineration).

The tar-like bottoms will remain in the distillation vessel, and the vessel will be sealed for disposal. The distillation vessels will be changed when fouling of the heating coils occurs. Three to five vessels are expected to be required. The vessels are 0.9 meter in diameter and 1.9 meters long, with an approximate weight of 860 kilograms. If the spent vessel is a transuranic waste, it will be stored at the Central Waste Complex until it is packaged for shipment to the Waste Isolation Pilot Plant. If the spent vessel is nontransuranic, the vessel will be stored at the Central Waste Complex for further treatment by the Waste Receiving and Processing Facility. Waste minimization is achieved by minimizing the number of vessel changeouts.

The offgasses will be vented back through the underground tanks to maximize condensation (minimizing gaseous effluents and the amount of activated charcoal required for treatment) and be treated by charcoal adsorption and filtration. The charcoal adsorbent will becolne a mixed waste. Approximately 270 kilograms of charcoal (three or four 0.21 -cubic meters drums) will be used.

As with the distillation phase, the incineration is itself a waste minimization effort because it will eliminate a dangerous waste (the incineration process will reduce the organic distillate to its relative atomic structures).

\subsubsection{Minimization}

Current waste minimization practice is to separate the hexone waste from nondangerous waste.

Planned treatment will reduce the volume of mixed waste from 136 cubic meters of hexone waste to less than 16 cubic meters of tar-filled vessels and 1 cubic meter of charcoal adsorbent. (The final volume projection is based on a total of up to five distillation vessels.) Further waste minimization is achieved by minimizing the number of distiliation vessel changeouts and the amount of charcoal required. 


\subsubsection{Variances, Exemptions, Time Extensions}

Hexone is a low-level mixed waste that is restricted from land disposal because it contains solvent list (40 CFR 268.30) constituents. The Tri-Party Agreement (Ecology et a). 1989) provides for continued storage of the hexone waste until treatment and disposal capacity for this waste is developed.

If additional variances, exemptions, or extensions of time are required as a result of delays in the development of treatment, storage, or disposal capacity, they will be applied for in accordance with the procedures detailed in the Tri-Party Agreement (Ecology et a1. 1989).

\subsection{3-H SOLAR BASIN WASTE}

The 183-H Solar Basins are a series of four concrete basins located in the 100-H Area. The 183-H Solar Basins were constructed in 1949. Originally there were sixteen flocculation and sedimentation basins that were a part of the 183-H Filter Plant. The filter plant provided water treatment, filtering units, and reservoir capacity for the 100-H Reactor process water system. In the spring of 1974, after decontamination, demolition of the 183-H Filter Plant was initiated. The $183-H$ head house, 12 of the flocculation and sedimentation basins, the filter building, and the clearwell pump room were demolished to ground level and the underground portions were backfilled to ground level. The remaining four basins were used from 1973 to 1985 to store and treat liquid chemical waste from 300 Area fuel fabrication plants. The purpose of the 183-H Solar Basins was to provide a means of waste reduction by natural solar evaporation.

The waste stored in the 183-H Solar Basins has undergone solar evaporation and the remaining 1 iquids are supersaturated and ready for further treatment (solidification). Liquid transfers between the basins have permitted the isolation and removal of waste precipitates and sludges. These absorbed sludges have been packaged in lined 0.21 -cubic meter drums and shipped to the Central Waste Complex. The remaining liquid is being solidified and the crystallized solids are being removed.

The 183-H Solar Basins have not received waste since November 1985. Waste is being removed from the basins but actual closure will not commence until the closure plan is approved by Ecology. Approval is anticipated in fiscai year 1991 .

\subsubsection{Generation}

This section describes the waste generation process and identifies amounts of waste generated.

4.9.1.1 Process. The 183-H Solar Basins were a storage and treatment (evaporation) unit for the liquid chemical waste generated at the 300 Area nuclear fuel fabrication plants. The basins received waste from 1973 through 1985 (DOE/RL 1990a). 
4.9.1.2 Generation. During the operating life of the 183-H Solar Basins a total of 9,623 cubic meters of routine waste was added to the basins. Table 4-12 presents the quantity of chemical constituents discharged to the basins.

In addition to the routine waste, nonroutine waste periodically was discharged into the 183-H Solar Basins. Nonroutine waste consisted of unused chemicals and spent solutions from miscellaneous processes, development tests, and laboratories. Nonroutine waste fell into three categories: 1 isted waste, nonl isted waste that was added directly to the 183-H Solar Basins, and nonlisted waste that was mixed with the routine wastestream before being transported to the 183-H Solar Basins. Only a small amount of listed ronroutine waste was discharged to the basins. The listed waste quantities were estimated to be 2 kilograms of solid materials and 9 liters of solution. Table 4-12 summarizes the discharges of listed, nonroutine waste into the 183-H Solar Basins. Nonlisted, nonroutine waste discharged Jirectly into the 183-H Solar Basins totaled approximately 50 kilograms of apparently dangerous solid materials, less than 5.3 cubic meters of apparently dangerous liquid waste, and 39 cubic meters of nondesignated waste. Internal chemical waste disposal permit' records indicate that about 44.30 cubic meters of 1 iquid waste and 700 kilograms of solid waste was mixed with routine waste before being discharged into the 183-H Solar Basins (DOE/RL 1990a).

Since 1985, a total of 1,014 cubic meters of sludge and 105 cubic meters of crystalline material has been removed from the basins and sent to the Central Waste Complex, and about 8,300 cubic meters of liquid have been 'removed' through evaporation and solidification. Waste remaining in the basins will be removed by January 1991.

\subsubsection{Characterization}

This section discusses the available waste characterization information. Information based on process knowledge and sample analyses is provided along with the waste designations and their bases, the uncertainty of the designations, and the schedule for further analysis.

4.9.2.1 Process Knowledge. The 183-H Solar Basins received both routine and nonroutine waste. The routine wastestream consisted of spent acid etch solutions (primarily nitric, sulfuric, hydrofluoric, and chromic acids) generated by the nuclear fuel fabrication process. Typically, these acidic solutions were neutralized with excess sodium hydroxide before being transported to the 183-H Solar Basins. Metal constituents in the waste included copper, silicon, zirconium, aluminum, chromium, manganese, nickel, and uranium. Following reaction with sodium hydroxide, these metals were present primarily in the form of precipitates. The resultant slurry of liquid and metal precipitates was transported and discharged into the 183-H Solar Basins.

Nonroutine waste was also discharged to the 183-H Solar Basins during its period of op iration. Before each addition, a review was performed to determine whether undesirable chemical reactions would take place. A 'chemical waste disposal permit' system was developed for acceptance of waste into the 183-H Solar Basins. The 'permit' system was for internal use only 
and should not be considered in the same context as a state or EPA 'permitted' system. These internal chemical waste disposal permits have left an historical record, which has been used to determine waste designations for the waste of the 183-H Solar Basins.

Nonroutine waste consisted of unused chemicals and spent solutions from miscellaneous processes, development tests, and laboratories. Nonroutine waste falls into three categories: listed waste, nonlisted waste chat was added directily to the 183-H Solar Basins, and nonlisted waste that was mixed with the routine wastestream before being transported to the 183-H Solar Basins.

The chemical waste disposal permits have shown that six different 1 isted nonroutine wastes were discharged into the 183-H Solar Basins. Table 4-13 identifies these wastes.

Twelve chemical waste disposal permits were for the discharge of nonlisted, nonroutine waste directly into the 183-H Solar Basins. This waste included: sodium arsenate acid; ammonium phosphate; nickel oxide; mixed. nickel, copper and iron oxides; solutions of sodium nitrate, sodium sulfate (anhydrous), sodium chloride, and sodium carbonate (corrosive); sodium carbonate sludge; used boiler cleaning solution containing ethylenediaminetetracetic acid, ammonium persulfate, aqua ammonia, ethylenediamine, hydrazine, and thiourea.

A common practice for disposal of nonroutine waste was to mix the materials with the routine wastestream before the waste was transported to the 183-H Solar Basins. The chemical waste disposal permits indicate that about 44 cubic meters of 7 iquid waste and 1,500 kilograms of solid waste were discharged to the 183-H Basins in this manner.

4.9.2.2 Sample Analyses. During the operating life of the 183-H Solar Basins, systematic chemical analyses were not performed for the routine waste discharges. In October 1984, the waste in Basin 1 was sampled. The waste contained three strata: a wet sludge, a liquid phase, and a relatively dry white stratum. In January 1986, the waste in Basin 2 was sampled. The waste consisted of a wet sludge and a liquid phase. During March 1987, the wet sludge and relatively dry crystalline strata in Basins 3 and 4 were sampled. At the same time, the consolidated liquid (from Basins 1, 2, 3, and 4) in Basin 2 was also sampled (DOE/RL 1990a).

The waste in the inner portion of Basin 1 consisted primarily of sludge intermixed with a residual liquid. The cleanout effort involved pumping as much liquid as possible into Basin 2; therefore, the results of the analytical results for the Basin 1 liquid are not discussed. The Basin 1 analytical results are addressed by the analysis of the liquid in Basin 2 . The outer basin waste was a relatively dry waste that was visibly different than the 'inner' basin waste; consequently, samples taken from this stratum were analyzed separately. During removal of waste from Basin 1, no attempt was made to segregate the different stratum. As a consequence, the most conservative designation resulting from the separate analyses was assigned to all waste from Basin 1. 
The results of inorganic chemical analyses for major constituents (greater than 1\%) are summarized in Table 4-14. These results showed that the waste consisted largely of sodium suifate, along with water held as moisture and as water of hydration. Nitrate and fluoride ions also were present in high concentrations. Copper constituted about $12 \%$ of the waste. The uranium concentration ranged from 390 to 530 parts per million.

Before remnving s?udge from Basin 2, samp?es of the liquid and sludge phases were analyzed for chemical constituents. As shown on Table 4-15, the major constituents in the sludge were copper (13\%), sodium ion $(9.7 \%)$, and nitrate ion (13.5\%). Moisture content in the sludge averaged 53\%. Uranium was present in the sludge in concentrations up to 2,500 parts per million.

The solid waste in Basins 3 and 4 was sampled concurrently; and the analytical results are similar enough to be treated in a single discussion. There were two visibly distinct waste strata in each of the basins. These consisted of a moist sludga (inner basin) and a relatively dry, white, crystalline stratum (outer basin) near the walls. Samples of the two strata were analyzed separately and each basin was sampled separately.

Table 4-16 provides a summary of the analytical results for major inorganic constituents found. The sludge stratum in both basins consisted primarily of sodium, nitrate, and copper ions. Moisture content in this stratum averaged greater than $40 \%$ in each basin. The "mystalline stratum contained high average concentrations of sodium and suirite ions. A major difference between the basins was that the nitrate ion concentration in the crystalline stratum in Basin 4 ranged from $7 \%$ to $70 \%$, while in Basin 3 the levels were all less than 1\%. The uranium concentration ranged from 7 to 1,560 picocuries per gram dry weight.

Volatile organic anplysis was performed on 10 samples of wet sludge from Basins 3 and 4 . The prinary reason for doing this analys is was to determine if tetrachloroethane and 1,1,1-trichloroethane (two solvents routinely used in the nuclear fuels fabrication process) had reached the 183-H Solar Basins via carryover into the routine wastestream. The analysis showed that neither solvent was present in detectable concentrations; therefore, the solvents were assumed not to be present.

Five samples of the consolidated liquid in Basin 2 were taken. Table 4-17 shows that the major constituents found were sodium and nitrate ions ( $14 \%$ and $38 \%$, respectively). Moisture content averaged $57 \%$. Table 4-18 provides a summary of trace inorganic constituents detected in the liquid. Uranium content for the liquid aleraged 82,400 picocuries per liter.

4.9.2.3 Waste Designation and Basis. The following are the bases for the waste designations:

- Pure chemical products identified on the internal chemical waste disposal permits

- Results of anaiyses conducted for characterizations of the waste foieach basin. 
The uranium content of the sludges and liquid is sufficient to classify them as low-level, nontransuranic radioactive waste.

Table 4-13 identifies six listed wastes that were discharged into the 183-H Solar Basins. Five of these materials were extremely hazardous waste. A11 the listed wastes were initially added to Basin 1 . However, because of subsequent transfers of the liquids among the 183-H Solar Basins, all of the 183-H Solar Basins have been designated as having contained these listed materials. As a consequence, waste codes applicable to all basin waste are U123 (formic acid), P030 (soluble cyanide salts), P120 (vanadium pentoxide), P029 (copper cyanides), P106 (sodium cyanide), and P098 (potassium cyanide).

Additional waste designations for waste of each of the 183-H Solar Basins are as follows:

- Basin 1 (solid):

WTO1 (fluoride ion concentration)

- Basin 2 (sludge):

WT02 (fluoride ion concentration); D007 (TCLP chromium)

- Basin 3 and 4:

WTO1 - (fluoride ion concentration)

- Basin 2 (1iquid):

WTO1 - (fluoride concentration); D007 (TCLP chromium).

4.9.2.4 Uncertainty of Waste Designation. The designations of the 183-H Solar Basin waste are considered accurate.

4.9.2.5 Schedule for Further Characterization. No further analyses are planned.

\subsubsection{Storage}

As of September 1, 1990, it is estimated that there were 100 cubic meters of crystalline material and 28 cubic meters of liquid remaining in the 183-H Solar Basins. This crystalline material is being removed and should be removed completely by the end of 1990 . The crystalline material is being packaged in drums and transported to the Central Waste Complex.

There have been releases of hazardous materials from the 183-H Solar Basins. Estimates of the amount of material released currently are unavailable.

The waste removed from the 183-H Solar Basins and generated by closure activities will be stored in the Central Waste Complex.

The Central Waste Complex is operated in compliance with all applicable federal and state requirements related to mixed waste storage. Further details on this facility are provided in Section 4.13. The storage unit compliance status of the Central Waste Complex is discussed in

Section 4.13.3.3. 
DOE/RL-90-41

\subsubsection{Treatment}

Current treatment involves packaging the 183-H Solar Basin waste for temporary storage and moving it to the Central Waste Complex.

All the dangerous waste from the 183-H Solar Basins will be retrieved for processing in the Central Waste Complex's Waste Receiving and Processing Facility, a multipurpose waste reduction facility that is scheduled to start operation in 1996. The Waste Receiving and Processing Facility is described in Section 4.13.4.2.

\subsubsection{Minimization}

The quantity of 183-H Solar Basin waste requiring disposal has been minimized by solar evaporation. To minimize the waste generated when solidifying the remaining saturated, unevaporated liquid, 13 different liquid waste solidification agents were studied for packaging efficiency. The solidifying agent chosen provided a high-packaging efficiency, allowing 0.15 cubic meter of liquid to be solidified and packaged into a 0.21 -cubic meter drum.

\subsubsection{Variances, Exemptions, Time Extensions}

The 183-H Solar Basins will undergo closure in accordance with an approved closure plan (DOE/RL 1990a). The facility either will be clean closed or closed as a landfili. The choice of closure method currently is being evaluated. The dangerous waste and waste residues are placed in containers and transported to the Central Waste Complex for storage as discussed in Section 4.9.3. This waste is managed with other waste stored at the Central Waste Complex.

The 183-H Solar Basins waste consists of low-level waste containing dangerous waste constituents. The $183-\mathrm{H}$ Solar Basin waste is restricted from land disposal because it contains solvent waste (40 CFR 268.30) and California list waste ( 40 CFR 268.32). It al so contains waste covered by the Third Third Promulgation (55 FR 22520).

The Third Third Promulgation (55 FR 22520) provided for a 2-year national capacity variance from the 1 and disposal restrictions for Third Third mixed waste. This variance allows continued storage of these wastes. In the event that sufficient treatment capacity for this waste is not available at the expiration of this variance (August 1992), the Tri-Party Agreement will allow continued storage of this waste until sufficient treatment capacity is available in accordance with the schedules in the agreement.

The Tri-Party Agreement (Ecology et al. 1989) provides for continued storage of California list ( 40 CFR 268.32) and solvent waste (40 CFR 268.30) until treatment capacity is developed for these wastes.

183-H Solar Basins closure waste will be stored at the Central Waste Complex until treatment by the Waste Receiving and Processing Facility and 
subsequent disposal at appropriate disposa? unit. Variances for the Central Waste Complex are discussed in Section 4.13.6.

An additional variance also is required to allow alternative treatment of waste code U123 (formic acid), for which the required treatment is incineration or fuel substitution. Currently, there is no incineration capacity planned for mixed waste at the Hanford Site.

If additional variances, exemptions, or extensions of time are required as a result of delays in the development of treatment, storage, or disposal capacity, they will be applied for in accordance with the procedures detailed in the Tri-Party Agreement (Ecology et al. 1989).

\subsection{PUREX TUNNEL 2 WASTE (Mercury)}

This liquid low-level waste is contained in discarded dissolver for irradiated fuel. The elemental mercury is sealed inside thermowells that are an integral part of the irradiated fuel dissolvers.

As of April 1, 1990, 0.01 cubic meter of elemental mercury is stored in PUREX Storage Tunnel 2. The mercury is designated D009 (TCLP-mercury) and WTO1 (toxic) (DOE/RL 1990b).

\subsubsection{Generation}

This section describes the waste generation process and identifies the volume generated.

4.10.1.1 Process. Elemental mercury waste is generated when dissolvers in the PUREX process fail or are deemed to be obsolete (hereafter referred to as being discarded). The mercury becomes a waste because its removal from the discarded dissolver is not practical.

The elemental mercury is sealed inside thermowells, which are an integral part of reactor fuel dissolvers used at the PUREX PIant. There are two thermowells per dissolver. Each thermowell consists of a 2.9-meter length of stainless steel pipe with an extension welded to the downside end. The lower end butts against the outer surface of the internal slotted bar screen that separates the undissolved fuel elements from the outer solution chamber of the annular dissolver. The mercury serves to transter heat from the dissolver interior to the temperature sensor mounted within the thermowel1. This mercury remains in the thermowells of discarded dissolvers. In preparation for storage, the thermowell is sealed with a stainless steel nozzle plug. In storage, the discarded dissolver rests in an inclined position in a cradle on a railcar. Secondary containment is provided by the dissolver vessel itself.

4.10.1.2 Generation. As of October 1990, three dissolvers have been discarded: one in 1971, a second in 1972, and a third in 1986. The first two dissolvers each contain 44 kilograms of elemental mercury, while the third one contains 38 kilograms. All three dissolvers are stored on railcars in PUREX Storage Tunnel 2 (DOE/RL 1990b). 


$$
\text { DOE/RL-90-41 }
$$

If the PUREX Plant is selected as the preferred option for disposition of stored reactor fuel, estimates of future mercury waste generation will be developed during restart planning. However, during the PUREX Plant standby, elemental mercury waste may be generated.

\subsubsection{Characterization}

This section discusses the available. waste characterization information. Information based on process knowledge and sample analyses is provided along with the waste designations and their bases, the uncertainty of the designations, and the schedule for further analysis.

4.10.2.1 Process Knowledge. Characterization of the mercury waste relies on fabrication and installation specifications. The quantity of mercury present in each dissolver is documented on the fabrication drawings. None of the mercury will evaporate because each thermowell is sealed.

4.10.2.2 Sample Analyses. Sampling and chemical analysis is nat performed on mercury associated with the dissolvers. The need for sample analyses wiil be evaluated during planning for closure of the PUREX Plant including the PUREX Storage Tunnels.

4.10.2.3 Waste Designation and Basis. The basis for the designation of mercury waste is process knowledge, and the fabrication and installation specifications.

Elemental mercury exhibits the characteristic of toxicity as determined by the toxic characteristic leaching procedure and is designated D009. The quantity of mercury present, if exposed to a leachate, could produce an extract greater than 20 milligrams per liter. This dictates that the mixed waste be managed as extremely hazardous waste and is further designated as toxic (WTOL) (DOE/RL 1990b).

4.10.2.4 Uncertainty of Waste Designation. The designation of the PUREX Storage Tunnels mercury waste is considered accurate.

4.10.2.5 Schedule for Further Characterization. The need for additional waste characterization will be evaluated during planning for closing the PUREX Storage Tunnels.

\subsubsection{Storage}

This section discusses the PUREX Storage Tunnels, provides their storage capacity and the amount of waste stored, and assesses the compliance status of the storage unit.

4.10.3.1 Storage Unit and Capacity. The PUREX Storage Tunnels are a mixed waste storage unit. The two tunnels are connected by rail to the PUREX Plant and combine to provide storage space for 48 railroad cars (railcars). The PUREX Storage Tunnels provide long-term storage for process equipment removed from the PUREX Plant. Equipment transfers into the PUREX Storage Tunnels are made on an as-needed basis. Radioactively contaminated equipment is loaded on 
railcars and remotely transferred by rail into the PUREX Storage Tunnels. Railcars act as both a transport means and a storage platform for equipment placed into the tunnels.

The tunnels are weather-tight structures covered by 2.4 meters of earth. This design serves to protect the stored equipment from exposure to natural elements, provides externa? radiation shielding from the radioactive equipment stored inside the tunneis, and provides for the protection of the environment.

Tunnel 1 (218-E-14) was completed in 1956 as part of the PUREX Plant construction project and provides storage for eight railcars. Tunnel 1 was filled to capacity (approximately 600 cubic meters of waste) in 1965 and subsequently was sealed. There is no elemental mercury waste stored in Tunnel 1.

Tunnel 2 (218-E-15) was an expansion project constructed in 1964. This tunnel is different in design and is considerably longer than Tunnel 1 , providing storage space for a total of 40 railcars. A more complete description of the PUREX Storage Tunnels may be found in PUREX Storage Tunnels Dangerous Waste Permit Application, Rev. 0 (DOE/RL 1990b).

PUREX Storage Tunnel 2 has a maximum storage capacity of 40 railcars. Each railcar will hold 77 cubic meters of waste. To date, $43 \%$ of the storage area is filled, as 17 railcars holding 1,360 cubic meters of discarded equipment and associated waste have been placed in the tunnel. Sufficient storage capacity exists for all future waste projected to be generated.

4.10.3.2 Amount In Storage. The amount of elemental mercury currently being stored in PUREX Storage Tunnel 2 is 0.01 cubic meter (130 kilograms).

Additional mercury waste may be placed into storage. The amount of future mercury waste generation will be evaluated during restart planning.

4.10.3.3 Storage Compliance Assessment. Elemental mercury waste is stored in PUREX Storage Tunnel 2, a mixed waste storage unit. The PUREX Storage Tunnels do not have secondary containment structures; however, the mercury waste stored is contained in the thermowells of the dissolver vessels, and the outer shell of the dissolver provides secondary containment. Personnel entry (to inspect the waste storage area) is not practical because of the high levels of radiation present inside the tunnel, wh ch would not meet the requirements of the Atomic Energy Act (1954) to maintain radiation exposure as low as reasonably achievable. The PUREX Storage Tunnels Dangerous Waste Permit Application was submitted to the State of Washington Department of Ecology in September 1990, in accordance with the Tri-Party Agreement (Ecology et al. 1989). No additional compliance actions have been identified for the PUREX Tunnels.

\subsubsection{Treatment}

Planned treatment of the eleniental mercury waste stored in PUREX Tunnel 2 is detailed in the Part B Dangerous Waste permit application (DOE/RL 1990b). The EPA required treatment technology for elemental mercury is amalgamation 
(52 FR 22520). Therefore, the treatment of choice is the current approach of adding zinc powder to create an amalgam. An alternative treatment being considered is to mineralize the elemental mercury (creating elemental mercury sulfide). After treatment, waste still classified as mixed waste will be placed in approved transport packaging and stored in an authorized Hanford Site storage unit or sent to a permitted disposal unit.

\subsubsection{Minimization}

The elemental mercury in PUREX Tunnel 2 will be separated from other waste categories to minimize the volume of waste requiring processing and disposal as mixed waste.

\subsubsection{Variances, Exemptions, and Time Extensions}

Elemental mercury waste was placed in the PUREX tunnels before November 1987 (the effective date of the land disposal restrictions for mixed waste) and, therefore is not subject to land disposal restrictions until the waste is removed from the tunnels. Removal of elemental mercury waste is planned as part of the closure of the PUREX Plant. At that time, waste will be removed from the PUREX Tunnels, treated to comply with land disposal restriction treatment standards, and disposed of at a permitted disposal unit.

If variances, exemptions, or extensions of time are required as a result of delays in the development of treatment, storage, or disposal capacity, they will be applied for in accordance with the procedures detailed in the Tri-Party Agreement (Ecology et a1. 1989).

\subsection{PUREX TUNNELS 1 AND 2 WASTE (LEAD AND SILVER)}

The PUREX Storage Tunnels 1 and 2 contain 0.26 cubic meter of elemental lead and PUREX Tunnel 2 contains 0.17 cubic meter of silver (mostly as silver nitrate). The estimated volume of equipment associated with the elemental lead is 234 cubic meters. The estimated volume of equipment associated with the silver nitrate is 147 cubic meters (DOE/RL 1990b, Appendix A). The lead is in jumper counterwsights and equipment shielding, and the silver is in discarded silver reactors.

The elemental lead waste is TCLP toxic for lead (D008) and also is designated WTO1. The silver nitrate waste is classified as TCLP toxic for silver (DO11) and ignitable (DOO1) because of the presence of nitrates.

\subsubsection{Generation}

This section describes the waste generation process and identifies the volume generated.

4.11.1.1 Process. Elemental lead waste is generated in the PUREX process as an integral part of equipment, such as process pipe jumpers, jumper alignment tools, and shielding equipment. Historically, elemental lead was used as 
DOE/RL-90-41

weight, counterweight, and radiation shielding in the fabrication of process equipment used in the PUREX Plant; generally, the lead was encased in steel (carbon or stainiess) to facilitate its at+achment to process equipment. Coulterweighted jumper assemblies are cise. i to facilitate remote installation of in-cell process and service piping. A jumper alignment tool may have contained as much as 682 kilograms of lead. This tool is used as a weight to pull down the free end of a jumper so that the connecting parts align vertically and the connection can be made.

Silver in the form of silver salts deposited on unglazed ceramic packing is contained within the discarded silver reactors stored in Tunnel 2 . Three silver reactors were used to remove radioactive iodine from the offgas streams of the irradiated reactor fuel dissolvers in the PUREX process. The silver reactor vessel contains two beds of packing. The packing is conted initially with 114 kilograms of silver nitrate used for iodine retention. Nozzles on the top of the reactor are provided to allow flushing and/or regeneration of the packing with silver nitrate solution as the need arises.

Experience has shown that after extended use, the silver reactors lose efficiency. This loss in efficiency normally occurs when about one-half of the silver nitrate on the packing has been converted to silver iodide. other competing reactions such as reduction of silver nitrate to metallic silver and formatioil of silver chloride al so occur and affect silver reactor efficiency. Therefore, regeneration of the silver reactor with fresh silver nitrate is performed periodically. Thus, the packing of the discarded silver reactor contains a mixture of silver nitrate, silver halides, and silver fines.

4.11.1.2 Generation. If the PUREX Plant should be selected as the preferred option for the disposition of stored reactor fuel, future lead and silver waste generation will be evaluated as part of restart planning. However, during PUREX standby, elemental lead and silver nitrate waste may be generated by $p l a n t$ maintenance activities.

\subsubsection{Characterization}

This section discusses the available waste characterization information. Information based on process knowledge and sample analyses is provided along with the waste designations and their bases, the uncertainty of the designations, and the schedule for further analysis.

4.11.2.1 Process Knowledge. The quantity of lead generated is determined from a review of fabrication and design drawings for each piece of equipment placed in storage if the leadweight, counterweight, or shielding is specifically detailed. The silver salts quantity is estimated from the knowledge of the amourit of silver nitrate placed on the bedding and the regeneration histury of the silver reactors. For accountability purposes, the total silver content is considered to be silver nitrate, the salt that exhibits the characteristics of both ignitability and TCLP toxicity.

4.11.2.2 Sample Analyses. Sampling and chemical analys is is not performed on lead or silver salts associated with the radioactive discarded equipment placed in the PUREX Storage Tunnels. The quantity of lead in storage is determined from process knowledge. Provicions for taking samples of the 
bedding were not provided in the design of the silver reactor vessels. Therefore, sampling and chemical analys is are not performed for silver salts before placing a silver reactor in storage.

4.11.2.3 Waste Designation and Basis. Elemental lead exhibits' the characteristic of toxicity as determined by the TCLP and is designated D008. The form of lead present could produce an extract greater that 500 willigrams per liter should it be exposed to a leachate; therefore, the mixed waste is managed as extremely hazardous waste and is further designated as WTO1. However, because the bulk of the lead is encased in steel on railcars that isolate the lead from other materials stored within the tunnel, the potential for exposure of lead to a leachate is considered to be negligible.

Silver salts exhibit the characteristics of toxicity as determined by the TCLP and are designated D011. The form of silver present could produce an extract having greater than 500 milligrams of silver per liter should the salts be exposed to a leachate; therefore, the mixed waste is managed as extremely hazardous waste and is further designated as WTO1. In addition, nitrates exhibit the characteristic of ignitability and are desigated 0001 .

4.11.2.4 Uncertainty of Waste Designation. The designated waste codes for the lead and silver waste are considered accurate.

4.11.2.5 Scheduie for Further Characterization. The need for additional waste characterization will be evaluated during planning for closing the PUREX Storage Tunnels.

\subsubsection{Storage}

The PUREX Storage Tunnels, their storage capacity, and the compliance status of the storage unit are discussed in Section 4.10.3.

As of October 1990, 0.26 cubic meter of elemental lead is stored in PUREX Storage Tunnels 1 and 2, and 0.17 cubic meter of silver nitrate is stored in Storage Tunnel 2. The estimated volume of equipment associated with the elemental lead is 234 cubic meters. The estimated volume of equipment associated with the silver nitrate is 147 cubic meters (DOE/RL 1990t).

The amounts of lead and silver placed in the storage tunnels are given in Table 4-19. The estimated quantity of lead listed in Table 4-19 accounts onlj for the lead in alignment tool and jumper counterweights. Counterweights on equipment dunnage and lead used for shielding cannot be quantified by existing historical records and are not included in the estimated quantity of lead in storage.

The quantity of silver salts listed in Table 4-19 are a function of time of reactor use, the regeneration history and the impurities in the process chemicals that may have reacted with the silver nitrate. Sample analyses have not been conducted to verify the predicted quantities present. 


\subsection{Treatment}

Planned treatment of the elemental lead and the silver salts associated with the process equipment stored in the storage tunnels is detailed in DOE/RL 1990b. The elemental lead will be removed, where feasible, from the process equipment, to reduce the volume to be treated. The elemental lead, as well as the silver salts located in the silver reactors, are planned to be treated by encapsulating the material in a cementitious grout that immobilizes the lead and silver.

\subsubsection{Minimization}

Since early 1987, the use of lead in the design and fabrication of new replacement equipment for the PUREX Plant has been discontinued wherever feasible.

The silver and elemental lead in the PUREX Storage Tunnels will be separated from other waste categories to minimize the volume of waste requiring processing and disposition as mixed waste.

\subsubsection{Variances, Exemptions, and Time Extensions}

Elemental lead waste, silver nitrates, silver salts, and silver fines (low-level mixed waste) were placed in the PUREX storage tunnels before November 1987 and are, therefore, not subject to land disposal restrictions until the waste is removed from the tunnels. Removal of elemental lead waste and silver nitrates, silver fines and silver salts is planned as part of the closure of the PUREX Plant. At that time, waste will be removed from the PUREX Storage Tunnels, treated to comply with land disposal restriction treatment standards, and disposed of at a RCRA-compliant disposal facility.

If variances, exemptions, or extensions of time are required as a result of delays in the development of treatment, storage, or disposal capacity, they will be applied for in accordance with the procedures detailed in the Tri-Party Agreement (Ecology et al. 1989).

\subsection{PUREX CANYON WASTE PILE (LEAD)}

Discarded process equipment removed from service in the PUREX PIant and known to have shielding, weights, and/or counterweights containing elemental lead are stored up to 5 years in a waste pile located on the canyon deck of the PUREX Building.

Segregation of lead into a waste pile began in December 1987 . The current inventory (as of October 1, 1990) is approximately 0.24 cubic meter (approximately 2,750 kilograms) of radioactively contaminated lead (mixed waste). The lead stored in the PUREX Canyon Waste Pile currently is untreated. The preferred disposal option is macroencapsulation. 


\subsubsection{Generation}

This section discusses the waste generation process.

4.12.1.1 Process. The PUREX Plant is located in the 200 East Area of the Hanford Site. It processes irradiated nuclear fuel by separating usable actinides from fission products. The PUREX PIant was constructed in 1955 and has operated intermittently as needed since then.

The lead in the PUREX Canyon Waste Pile consists of material that had been used for shielding, weights, or counterweights in the PUREX Plant. In most cases, the lead is totally enclosed in steel. However, some of the lead sheeting used in shielding is unclad. Since early 1987, the use of lead in the design and fabrication of new or replacement equipment for the PUREX Plant has been discontinued wherever feasible.

Specific equipment items that utilize protective radiation shielding include certain diaphragm-operated valves and neutron monitors used for process control. The amount of lead required for such purposes varies from about 91 kilograms for the shielding around a small diaphragm-uperated valve to as much as 1,400 kilograms of lead for a single neutron monitor.

Massive lead weights, up to 680 kilograms, are used as jumper alignment tools in the remote installation of some jumpers. Such tools assist in the vertical alignment so connection can be made. Jumpers are rigid lengths of pipe used to connect lines providing solution transfer to and from process equipment. Counterweights are attached to some of the jumpers to provide proper balancing for remote installation by the overhead maintenance cranes. A typical jumper counterweight consists of appropriately sized steel pipe filled with lead shot (approximately 45 kilograms) and welded shut on both ends.

4.12.1.2 Generation. If the PUREX Plant is the preferred option for the disposition of stored reactor fuel, lead waste generation rates will be developed during restart planning. Lead waste may be generated during standby of the PUREX Plant, but data are not available to estimate this generation rate.

\subsubsection{Characterization}

This section discusses the waste characterization and the basis for the waste characterization. The waste designation, the uncertainty of the designation, and the schedule for further characterization al so are provided.

4.12.2.1 Process Knowledge. The waste comes from discarded radioactive process equipment with lead shielding, weights, or counterweights. The waste is characterized as lead based on knowledge of the amount and material used to manufacture a specific equipment component as determined from review of the fabrication and design drawings for each piece of discarded equipment.

4.12.2.2 Sample Analyses. No chemical analys is of the waste has been performed and is not required because the waste is accurately characterized based on process knowledge. 
4.12.2.3 Waste Designation and Basis. The waste (elemental lead) is designated TCLP toxic for lead (D008) and toxic. (WTO1). The material is a solid, noncombustible metal.

4.12.2.4 Uncertainty of Waste Designation. The waste designation is accurately known, based on process knowledge.

4.12.2.5 Schedule for Further Characterization. No further characterization of this waste is scheduled.

\subsubsection{Storage} status.

This section describes the storage unit and assesses its compliance

4.12.3.1 Description of Storage Unit and Capacity. The PUREX canyon is a portion of the plant with thick concrete floor, walls, and celling (up to 1.8 meters thick). Work in the canyon is generally performed remotely due to high radiation levels.

Discarded process equipment with lead attachments are stored on the south side of the canyon. Periodically, lead-containing components are cut from the equipment and either returned to the waste pile or are placed in a metal box suitable for transfer by railcar into the PUREX Storage Tunnels. The remaining nonlead-containing equipment is segregated from the lead waste pile and disposed of as low-level waste.

Because the waste pile is located inside the building, the waste pile is protected from external environmental forces such as wind, rain, and run-on flooding. A system of drains and sumps ensures that any liquids from the waste pile are routed to appropriate waste storage tanks.

All lead components accumulated over successive 5-year periods will be transferred to an approved mixed waste storage container(s). These containers will be transferred to the PUREX Storage Tunnels or other approved storage unit.

4.12.3.2 Amount in Storag®. The quantity of lead waste in storage is 0.24 cubic meters $(2,750 \mathrm{k} \|$ lograms $)$.

4.12.3.2 Storage Compliance Assessment. The PUREX Canyon Waste Pile is located on the canyon deck of the building. The waste pile is addressed in the Part A permit application for the PUREX Plant. The PUREX Plant waste management unit was reviewed for compliance with interin status dangerous waste regulations in accordance with the Tri-Party Agreement milestone number M-21-00 (Ecology et a1. 1989). No interim status compliance deficiencies were noted.

A Part B permit application for the PUREX Canyon Waste Pile will be submitted in September 199', addressing compliance with final status regulations. 


\subsubsection{Treatment}

Although treatment units could be built to separate the contained lead from its encasement and possibly refine the lead to remove radioactive contamination, it is doubtful if unrestricted release of the refined lead could be achieved. Therefore, the preferred treatment alternative currently is identified as macroencapsulation (52 FR 22520).

\subsubsection{Waste Minimization}

Since early 1987, the use of lead counterweights in the design and fabrication of new or replacement equipment for use in the PUREX PI ant has been discontinued wherever feasible. Nondangerous materials such as carbon or stainless steel are substituted for lead wherever practical.

\subsubsection{Variances, Exemptions, Time Extensions}

The PUREX Canyon Waste Pile waste is a low-level mixed waste restricted from land disposal by the Third Third Promulgation (55 FR 22520). The Promulgation provided a 2 year national capacity variance from the Land Disposal Restriction for mixed waste. If sufficient treatment capacity for this waste is not available at the expiration of this variance (August 1992), the Tri-Party Agreement (Ecology et al. 1989) will allow continued storage of this waste until treatment and disposal capacity is available.

Removal of the PUREX Canyon Waste Pile is planned as part of the closure of the PUREX PIant. At that time, waste will be removed from the PUREX Canyon Waste Pile, treated to comply with land disposal restriction treatment standards, and disposed of at a permitted disposal facility.

If variances, exemptions, or extensions of time are required as a result of delays in the development of treatment, storage, or disposal capacity, they will be applied for in accordance with the procedures detailed in the Tri-Party Agreement (Ecology et al. 1989).

\subsection{CENTRAL WASTE COMPLEX STORED LOW-LEVEL, TRANSURANIC, AND POLYCHLORINATED BIPHENYL WASTE}

The Central Waste Complex receives radioactive solid waste and provides temporary storage until treatment at the Hanford Site.

Waste is received at the Central Waste Complex from all radioactive waste generators at the Hanford Site and any offsite generators that are authorized by the DOE to ship waste to the Hanford Site for treatment and disposal. The waste received at the Central Waste Complex is generated by ongoing Site operations (e.g., Plutonium Finishing Plant operation, waste management, etc.), and research and development activities conducted at the Site (e.g., single-shell tank waste sampling and analysis). The characteristics of the waste received at the Central Waste Complex vary greatly from waste that is nondangerous low-level waste to transuranic dangerous waste. The Central 
Waste Complex currently stores, as of June 30, 1990, approximately 1,400 cubic meters of low-level mixed waste subject to land disposal restrictions and 111 cubic meters of transuranic mixed waste subject to 1 and disposal restrictions. Other dangerous waste that is not restricted from iand disposal is stored at the Central Waste complex and is not included in these figures.

No treatment units currently exist for polych' inated biphenyls contaminated with transuranic or low-level waste; srefore, this waste is being held in storage at the Central Waste Complex until treatment capability exists. The Hanford Site polychlorinated biphenyls inventory includes contaminated liquids (polychlorinated biphenyl-contaminated hydraulic fluid), contaminated combustible solids, and contaminated equipment (transformers, capacitors, and fluorescent light ballasts). There currently are 87 cubic meters of polychlorinated biphenyl-contaminated low-level waste and 111 cubic meters of polychlorinated biphenyls contaminated transuranic waste.

\subsubsection{Generation}

This section describes the generation of radioactive mixed waste and radioactive polychlorinated biphenyls waste shipped to the Central Waste Compiex.

4.13.1.1 Mixed Waste Generation. The majority of the waste shipped to the Central Waste Complex is generated in small quantities by routine plant operation and maintenance activities. Specifying generation rates and types of waste generated by each plant is difficult because this waste is not generated as a direct result of process operations. The overall volumes of mixed waste projected to be generated are given in Table 4-20. No data are available on the fraction of this waste that will be subject to land disposal restrictions, but the majority of this newly generated mixed waste probabiy will be subject to the land disposal restrictions. The dangerous waste designation of each container of waste is determined at its point of generation based on knowledge of the waste placed in the container. The major plants that generate mixed waste that is land disposal restricted and the general type of waste they generate are discussed below.

The PUREX PIant was used in the past to process irradiated nuclear fuel from the $N$ Reactor. The PUREX process uses a nitric acid solution to dissolve the fuel and a solvent extraction process to separate the various fission products from the uranium, plutonium, and neptunium product streams.

Radioactive solid waste is generated in all parts of the PUREX Plant from routine laboratory operations to equipment maintenance. The mixed solid waste typically generated at the PUREX plant includes lear shielding, decontamination solvents, mercury-filled light tubes, and other nonroutinely generated radioactive solid waste.

The Uranium Oxide Plant, 7ocated in the 200 West Area, converts uranyl nitrate solution generated from the reprocessing of $N$ Reactor fuel to uranium oxide solids which are shipped offsite for re-use. The primary source of mixed waste at the Uranium Oxide Plant is solvents and mineral acids (HNO $_{3}$ and $\mathrm{H}_{2} \mathrm{SO}_{4}$ ) used for decontamination or equipment maintenance in radiation areas. other sources of land disposal restricted mixed waste at the Uranium Oxide Plant include contaminated fluorescent tubes and failed equipmerit. 
The 222-S laboratories, located in the 200 West Area, are used to analyze radioactive samples in support of waste management operations and tank characterization. These operations generate both solid and liquid mixed lowlevel waste. The solid waste generated by this laboratory includes the following:

- Radioactively contaminated lead

- Outdated chemicals and reagents

- Equipment and absorbent materials contaminated with radioactive waste.

The liquid low-level mixed waste is generated when using organic solvents to analyze radioisotopes.

The B Plant, located in the 200 East Area, currently is being prepared to pretreat waste that is going to be vitrified. Maintenance activities generate small quantities of solid waste such as lead shielding, equipment decontamination agents, paint and painting supplies, and fluorescent light ballasts. This waste is generated on an as-needed basis because of piant maintenance and upgrading.

The T Plant, located in the 200 West Area, is used to decontaminate failed equipment to facilitate repair, reuse, or disposal as noidangerous lowlevel waste. The solid waste generated as a result of these operations includes spent solvents, failed equipment, lead shielding, paint and painting supplies, and metallic vapor lights.

The $\mathrm{N}$ Reactor, located in the $100 \mathrm{~N}$ Area, currently is not operating. There are numerous sources of mixed low-level waste in the $100 \mathrm{~N}$ Area that generate waste oils, solvents, and decontamination solutions that in the past have been determined to be dangerous waste. In addition, the $100 \mathrm{~N}$ Area is the location of the 183-H Solar Basins (Section 4.10), which are the source of a large quantity of waste (approximately 923 cubic meters) currently being removed and transported to the Central Waste Compiex.

The 300 Area Fuels Manufacturing Operations generates several mixed lowlevel wastestreams. These operations have been shut down since December 1986, and the only waste generated from these uperations is from decontaminating and closing these operations. A detailed description of the waste is provided in Section 4.17. The waste is being transferred to the Central Waste Complex as part of the closure activities for the 303-K Facility.

The Fast Flux Test Facility, in the 400 Area, and associated research and development activities generate several wastestreams that are low-level mixed waste. This waste includes waste sodium, which is discussed in Section 4.5, 4843 Sodium Storage Facility waste, spent ethyl alcohol waste, listed solvent residual waste, contaminated lead residual waste, and decontamination waste. Spent ethyl alcohol waste is generated by cleaning of Materials Open Test Assembly specimens to remove residual sodium. This waste exhibits the characteristic of ignitability (D001) and corrosivity (D002). Listed solvent residual waste is generated by the use of listed solvents in plant maintenance activities, such as manipulator repair and paintir.g. Contaminated lead residual waste is generated from the removal of lead shielding for repair and replacement. Decontamination waste is generated while decontaminating stainless steel components such as shipping casks, hot cells, or other 
equipment in the conduct of Fuels Material Examination Facility operations. The waste contains listed solvents and may contain sufficient concentrations of chromium, nickel, and silver to be designated TCLP toxic.

The research and development activities conducted by the Pacific Northwest Laboratory in the 300 and 3000 Areas generate numerous small-volume mixed wastestreams that are land disposal restricted. This waste is generated in the 303-C, 320,324, 325, 326, 327, 331, and 3720 Buildings. The laboratory waste may contain materials that are designated TCLP toxic (D003D011) or that are designated as ignitable (DOO1) or corrosive (D002). The waste designated as TCLP toxic is generated from the analys is of samples containing toxic metals and the disposal of contaminated equipment and lead shielding. The waste designated as corrosive or ignitable is generated by the use of scintillation cocktails containing ignitable solvents for the analysis of radionuclides.

The operation and maintenance of the single- and double-shell waste storage tank farms located in the 200 East and 200 West Areas generate several types of mixed waste. The waste includes equipment used for tank sampling and characterization, failed equipment and instrumentation, and small quantities of tank waste absorbed on clothing or rags. These wastestreams may be dasignated by some or all of the waste codes applicable to double-shell tanks. These codes include corrosivity (D002); TCLP toxicity for arsenic (D004), barium (D005), cadmium (D006), chromium (D007), lead (D008), mercury (D009), selenium (DO1O), and silver (DO11); spent halogenated solvents (FOOI); spent nonhalogenated solvents (F003); and toxicity (WTO1).

4.13.1.2 Polychlorinated Biphenyl Waste Generation. Polychlorinated biphenyl-contaminated transuranic and low-level waste is generated by maintenance and periodic flushing of polychlorinated biphenyl hydraulic systems, failure of transformers and capacitors, and removal of polychlorinated biphenyl ballasts from light fixtures located in radioactive contaminated areas. The waste is packaged and shipped as solid waste to the Central Waste Complex for storage.

The best available generation information is maintained in the computerized Richland Solid Waste Information Management System database. The Richland Solid Waste Information Management System contains only that information provided by the waste generator. In the past, exhaustive waste descriptions that could be used to accurately classify a waste were not required, and data entries such as "contaminated debris" and "mixed fission products" were common. Data from Richland Solid Waste Information Management System indicates that 87 cubic meters of polychlorinated biphenyl contaminated low-level waste and 111 cubic meters of polychlorinated biphenyl contaminated transuranic waste were generated between 1970 and June 1990.

Future generation of polychlorinated biphenyi-contaminated waste is expected to be variable. The generation of this wastestream is correlated with the failure rate of polychlorinated biphenyl transformers, capacitors, and fluorescent light ballasts. Additional generation may be related to general Hanford Site cleanup and decontamination/decommissioning activities. Site-wide cleanup efforts may identify soil-contaminated areas that will require cleanup and packaging. These cleanup efforts will be the only active source of polychlorinated biphenyl transuranic waste at the Hanford Site. 
DOE/RL $-90-41$

\subsubsection{Waste Characterization}

This section discusses waste characterization based on process knowledge and sample analysis, identifies known designations, and addresses any further characterization required or planned.

Before acceptance of any waste at the Central Waste Complex, it is packaged and characterized as described in Hanfor: Site Radioactive Solid Waste Acceptance Criteria. These criteria require that the generator of the waste characterize each individual container of waste with sufficient accuracy to permit proper segregation, treatment, certification, shipment, and storage.

4.13.2.1 Process Knowledge. The waste characteristics are determined by the waste generator based on documented knowledge of the process generating the waste or sampling, as appropriate. The generators of all waste shipped to the Central Waste Complex are audited periodically to ensure that waste is being characterized properly.

Complete process knowledge has been used to char.cterize polychlorinated biphenyl-contaminated transuranic and low-level waste currently in storage. Equipment containing polychlorinated biphenyls such as hydraulic systems, transformers, capacitors, and fluorescent light ballasts have been identified clearly. When failure of any of these components occurs, they are immediately handled and packaged as polychlorillated biphenyl transuranic or low-level waste material.

4.13.2.2 Sample Analyses. The waste characteristics are determined by the waste generator based on documented knowledge of sample analyses of the generated waste. The generators of all waste shipped to the Central Waste Complex are audited periodically to ensure that waste is being characterized properly.

Hydraulic systems and transformers have been sampled to determine polychlorinated biphenyls concentrations. Any waste from these systems is designated based on the concentration of polychlorinated biphenyls in the source system. Light ballasts are designated based on data from the manufacturers.

Additional sampling is planned when this waste is processed through the Waste Receiving and Processing Facility.

4.13.2.3 Waste Designation and Basis. Waste at the Central Waste Complex is designated based on the information provided by the generator and recorded in the Richland Solid Waste Information Management System database. This database includes designations based on process knowledge and sample analysis. Waste designations have been entered into the database since 1988 . When the designation was not found on the Richland Solid Waste Information Management System report, waste designation tables were used to assign a designation to the dangerous constituents identified in waste placed in storage before 1988 . Table 4-21 summarizes the volume and designation of the low-level mixed waste listed on Richland Solid Waste Information Management System in the Central Waste Complex. Table 4-22 summarizes the volume and designation of transuranic mixed waste listed on Richland Solid Waste Information Management System in the Central Waste Complex. 
4.13.2.4 Uncertainty of Waste Designation. The designation of the waste stored in Central Waste Complex is considered accurati.

4.13.2.5 Schedule for Further Characterization. No further characterization is required to accurately designate the present waste for storage. For some of the waste, additional characterization will need to be performed to determine proper treatment and disposal options. This characterization will be performed during processing at the Waste Receiving and Processing Facility. Further characterization maybe necessary for newly generated waste and/or as a result of change regulations.

\subsubsection{Storage}

This section describes the storage units associated with the Central Waste Complex and details the amount and characterization of the waste stored in these units.

4.13.3.1 Description of Storage Units and Capacity. The following storage units are included in Central Waste Complex:

- Flammable Mixed-Waste Storage Modules. Thirteen modules will be operational by the third quarter of fiscal year 1990 to store flammable low-level waste, transuranic waste, low-level mixed waste, and transuranic-mixed waste with flashpoints below $38 \cdot \mathrm{C}$. The total capacity will be 2460.21 -cubic meter drums. The modules are small preengineered buildings with 16.3 square meters of floor space each. Two modules are operating.

- Mixed-Waste Storage Buildings. Thirteen mixed-waste-storage buildings are operational to store all categories of mixed waste (including transuranic). The floor space of each building is 372 square meters. Each will have a 1,000-drum capacity with the exception of 2402-WG, which is planned for a 550-drum capacity for low flashpoint ?ow--level waste.

- Large Mixed-Waste Storage Unit. The large mixed-waste storage unit will be operational in four phases, from second quarter fiscal year 1991 for Phase I through second quarter fiscal year 1994 for Phase IV. The large mixed-waste storage unit will store all categories of lowlevel mixed waste with a 12,000-drum capacity each for the Phases I, III, and IV buildings and 19,000 drums for Phase II $(55,000$ drums total).

A conceptual layout of the Ceniral Waste Complex units is shown in Figure 4-16. A plan view is given in Figure 4-17.

The planned capacity of the Central Waste Complex to store low-level waste and transuranic mixed waste is 14,450 cubic meters. This capacity is adequate to store the current projected volumes of mixed waste to be generated through the year 1996, assuming no treatment of the stored waste. Current plans call for treatment of the mixed waste to begin in 1999, which will reduce the amount of waste in storage and make storage room available for newly generated mixed waste. 
4.13.3.2 Amount in Storage. The amount and classification of dangerous waste restricted from 1 and disposal currently in storage at the Central Waste Complex as of June 30, 1990, is shown in Table 4-21 and 4-22.

A.s of June 1990, 111 cubic meters of polychlorinated biphenyl transuranic waste has been placed in the 2401-W building for storaye. Existing storage capacity is judged to be adequate for any future generation.

As of June 1990, 87 cubic meters of polychlorinated biphenyl low-level waste has been placed in the 2401-W Building for storage. Existing storage capacity is judged to be adequate for any future generation.

4.13.3.3 Storage Compliance Assessment. The Central Waste Complex was reviewed for compliance with interim-status dangerous waste regulations during 1988.

The compliance assessment noted a specific area of noncompliance, the contingency plan. Compliance action schedules are being developed as part of the Tri-Party Agreement (Ecology et a1. 1989). Interim status compliance was achieved in June 1990.

The Part B permit application documenting compliance with all final status dangerous waste regulations is scheduled to be submitted in October 1991 (Ecology et al. 1989).

\subsubsection{Treatment}

This section describes the treatment of the mixed waste currently stored in the Central Waste Complex.

4.13.4.1 Description of Current Treatment. The waste in the Central Waste Complex is not currently undergoing any treatment but is in storage pending the construction and operation of the Waste Receiving and Processing Facility. The polychlorinated biphenyl, transuranic, and low-level waste is being stored until an approved processing facility is available.

4.13.4.2 Description of Proposed Treatment. The waste currently stored in the Central Waste Complex, except polychlorinated biphenyl waste, $w^{\prime} 11$ be treated at the Waste Receiving and Processing Facility. The Waste Receiving and Processing Facility will be constructed as two modules, witli Module 1 operational in 1996 and Module 2 operational in 1999. Module 1 (WHC 1990h) will provide examination, certification, and shipping for boxes and drums of low-level waste, but only drums would be opened and processed. It also will provide for decontamination of small items, primarily for lead recovery and decontamination of drums and overpacks. Most low-level radioactive mixed waste will be characterized and repackaged pending processing in Module 2 (WHC 1990h).

Module 2 will contain size reduction, remote handling, mixed waste treatment, and decontamination processes. All retrieved and newly generated low-level mixed waste and secondary solids from the Effluent Treatment Facility will be processed. Low-level contaminated lead will be decontaminated, or smelted and released for conditional reuse if possible. 
Low-level mixed waste and effluent treatment unit secondary solids will be characterized, treated, solidified, and repackaged. Low-level liquid organic waste will be characterized, repackaged and transported off site for incineration. All nonorganic low-level radioactive mixed waste will be treated and certified for disposal in accordance with all regulations, including the land disposal restrictions.

The Waste Receiving and Processing Facility will provide the treatment necessary to comply with land disposal restrictions and enable disposal. The Engineering Study for the Waste Receiving and Processing Facility Module 2 examined the mixed wastestreams that would feed the Waste Receiving and Processing Facility, examined potentially applicable treatment processes, and evaluated five alternative processing configurations (WHC 1990h). Following is a discussion of the treatment process that will be included in the Waste Receiving and Processing Facility for mixed waste.

A basic schematic showing potential radioactive mixed wastestreams with corresponding treatment processes is found in Figure 4-18. Major unit processes include the use of offsite incinerator for organics and animal waste; solidification for sludge aste and ion exchange resins; supercompaction for dry active waste; metals treatment including thermal oxidation, mineralization and refining; and miscellaneous processes such as drum handiing and treatment of decontamination solutions.

When retrieved drums enter the Waste Receiving and Processing Facility Module 1, they will be sent to the Open/Sort Conpaction enclosure. The Open/Sort Compaction operators will enter descriptive information on waste materials into the computer database and bar code labels will be applied to all drums exiting the Open/Sort Compaction enclosure. The transuranic and low-level waste drums each will be opened in separate enclusures, but the opening and sorting process will be similar. After entering the enclosure, each drum will be deheaded and tipped onto a vibrating sorting table, and the inner plastic liner opened. All sorting will be performed manually through gloveports with extension tools.

For drums that have been identified as containing potentially noncompliant items, those items will be removed, placed on a transfer cart, and transferred to Special Processing. Examples of noncompliant items inciude free or containerized liquids, high-efficiency particulate air filters, large quantities of particulates, aerosol cans, and suspect radioactive mixed waste. The vibrating table will have a liquid collection tank beneath for liquids that flow freely from the opened waste. Collected liquids will be transferred to Special Processing.

In the Special Processing enclosure, several operations will be carried out by operators through glove ports with the aid of extension tools. Any materials suspected of containing dangerous constituents will be sampled, and the samples will be transferred to the Sample Management area for transfer to Hanford Laboratories for characterization. Treatment and disposal methods will be determined on a case-by-case basis for materials identified as radiuactive mixed waste.

The Special Processing operators will enter descriptive information on waste materials into the computer database, bar code labels will be applied to 
all drums exiting the Special Processing area, and the drums will be routed back to nondestructive assay. Special Processing will include operations for the following:

- Mixed waste sampling

- Immobilization of particulates

- Absorption of liquids

- High-efficiency particulate air filter immobilization

- Pyrophoric material

- Aerosol cans

- Lead waste segregation.

The Waste Receiving and Processing Facility Module 2 (WHC 1990h) will contain the Mixed Waste Treatment processes, which will provide for all necessary treatment for low-leve? mixed waste to enable disposal of the treated residues. Waste received will include sludges, ion exchange resins, metallic waste, organic waste, and dry active waste. All newly generated waste containers will be accompanied by paperwork attesting to the physical, chemical, and radiological contents. Each container retrieved from storage will be accompanied by weight, dose rate, and smear survey data obtained during retrieval. Little or no other documentation may be available on these containers.

Waste requiring pretreatment is r. oadly categorized as dry solids, sludge, slurry, or ion-exchange resins. Incoming containers of dry soilids will be batch fed through a crusher, which will reduce solids to less than 5 centimeters in size. The other wastes will be dumped from their containers or sluiced from bulk tanks into either the resin tank, sludge tank, or slurry tank. Each of these tanks will be equipped with a heavy-duty mixer to mix the contents of the tanks into a homogeneous mixture. After mixing, the resin will be pumped directly to a solidification tank; the slurry will be pumped to a chemical conditioning tank for further treatment; and the sludge either will be pumped directly to a solidification tank or to a chemical conditioning tank for further pretreatment. Chemical conditioning could include pH adjustment, precipitation, or other chemical processes necessary to optimize subsequent solidification.

Four 4.3-cubic meter solidification mix tanks will be included in the Mixed Waste Treatment unit to solidify all sludges, slurries, and ion exchange resins. Based on typical waste-to-cement rations, each 4.3-cubic meter batch will contain approximately $50 \%$ waste and $50 \%$ additives. After mixing is complete, each tank batch will be discharged into approximately twenty 0.21 -cubic meter drums. Filled drums will be removed from the filling station by forklift to a drum-curing and inspection area. Curing will require 24 to 48 hours. After curing, the drums will be closed, labeled, and prepared for final shipment for disposal.

All containers that do not contain sludges or ion exchange resins will be moved from the receiving area by fork truck to the repackaging area. Organic and animal waste will be repackaged for shipment to the Idaho National Engineering Laboratory for incineration. Organic liquids will be pumped or poured from their containers and loaded into shipping containers. Absorbed organic waste and animal waste will be loaded manually into shipping containers. 
The types of metals to be treated in the Metals Treatment area include zirconium and zirconium/beryllium shavings and fines, beryllium powder, mercury metal, lead, and other miscellaneous metals. The processes used to treat these metals inciude thermal oxidation, mercury mineralization, lead refining, and solidification. Zirconium and zirconium/beryllium containers will be opened and dumped into a 1-cubic meter decant tank. The solid fraction will settle to the bottom of the tank and the liquid will be drawn off and transferred to liquid treatment.

The solid fraction will be removed from the bottom of the decant tank in approximately 23-kilogram batches for transfer to the thermal oxidizer, which is similar to a small, open-hearth incinerator. The thermal oxidizer unit will be fired with fuel oil and excess air to oxidize the metals to a stable form. The ash will be collected from the combustion chamber and baghouse filter for transport to the solidification process.

Mercury will be converted to mercuric sulfide to reduce its toxicity. The process will react mercury with a sulfide compound such as hydrogen sulfide or sulfur dioxide in a 1-cubic-meter stirred reaction tank.

Lead will be treated using a refining process. This process was developed at the Idaho National Engineering Laboratory and uses a small $(4,500$ kilograms) induction furnace. The lead will be placed in the furnac?, and fuel oil or propane burners will be ignited. The temperature will be hold at approximately $350^{\circ} \mathrm{C}$ until all the lead is molten. The molten mass will then be stirred and a flux agent added. Steam will be introduced in the bottom of the furnace to promote the formation of a dross, which floats to the top of the melt. This dross will contain some lead, dirt and other miscellaneous materials, and the radioactive species. The molten metal will be poured into ingots and reused. The dross will be solidified.

The solidification system will be used so stabilize oxidized zirconium ash, mineralized mercury, and dross from lead refining. The metals will be added to a 1.3-cubic-meter mix tank along with appropriate amounts of water and solidification chemicals. The waste/cement mixture will be loaded into drums for final disposal.

Miscellaneous solid metals will be encapsulated in cement. The metals will be placed in a drum or container with precast concrete walls approximately 5 to 8 centimeters thick. A grout mixture will be prepared in a 0.5-cubicmeter mix tank and poured into the drum cavity, thereby completely encapsulating the solid metals.

The proposed treatment for polychlorinated biphenyl transuranic and lowlevel mixed waste is destruction by incineration. There is no offsite facility operating with approval for polychlorinated biphenyl treatment and disposal that can accept polychlorinated biphenyl mixed waste from the Hanford Site. Therefore, the Westinghouse Hanford Company initiated a study to define the regulatory requirements and identify and evaluate polychlorinated biphenyl destruction and disposal options within the DOE complex. 


\subsubsection{Waste Minimization}

All plants and processes that generate waste that is shipped to the Central Waste Complex are required to have a waste minimization program and a low-level waste certification plan in place. The effectiveness and implementation of these programs are audited on a regular basis. The following are descriptions of key elements of these programs.

- To the extent practical, all mixed waste is segregated and packaged separately from low-level waste or transuranic waste that contains no dangerous constituents.

- The total volume of mixed waste generated is minimized to the extent possible by segregation, compaction, and consolidation.

- To minimize the generation of mixed waste, generators actively seek nonhazardous alternatives for the hazardous constituents in the ir processes.

- If allowed by regulation, mixed waste is treated to remove the dangerous constituents.

- Corrosive materials are neutralized (if allowed by regulation) to remove their corrosive character or are packaged in a manner to ensure integrity of the containment barriers.

- Methodology for radionuclide and physical/chemical characterization is identified.

- Waste handling, segregation, and certification are performed following detailed procedures.

- A Quality Assurance Program Plan and implementing procedures are required.

\subsubsection{Variances, Exemptions, Time Extensions}

The Central Waste Complex contains waste that is restricted from disposal because it contains constituents on the California list ( 40 CFR 268.32), solvents (40 CFR 268.30), and by the Third Third Tand disposal restrictions (55 FR 22520).

The Third Third Promulgation (55 FR 22520) provided for a 2-year national capacity variance from the land disposal restrictions for mixed waste. This variance allows continued storage of these wastes. In the event that sufficient treatment capacity for this waste is not available at the expiration of this variance (August 1992), the Tri-Party Agreement will allow continued storage of this waste until sufficient treatment capacity is available in accordance with the schedules in the agreement.

The Tri-Party Agreement (Ecology et al. 1989) provides for continued storage of California list ( 40 C $: R$ 268.32) and solvent waste ( 40 CFR 268.30) until treatment capacity is developed for these wastes. The agreement 
requires treatment and disposal capacity wastes to be developed on the following schedule:

- Completion of Waste Receiving and Processing Facility Module I, required to sort and repackage waste and initiation of operations by September 1996 (milestone M-18-00)

- Completion of Waste Receiving and Processing Facility Module II, required to provide waste treatment capabilities that minimize the land disposal of low-level radioactive and mixed waste by September 1999 (milestone M-19-00).

If additional variances, exemptions, or extensions of time are required as a result of delays in the development of treatment, storage, or disposal capacity, or the demonstrated need for using alternative treatment technologies, they will be applied for in accordance with the procedures detailed in the Tri-Party Agreement (Ecology et al. 1989).

The required treatment for polychlorinated biphenyl waste is incineration. Currently, there are no facilities available for incineration of mixed polychlorinated biphenyl waste. Alternative treatments currently are being investigated. The polychlorinated biphenyl waste will be stored at the Central Waste Complex until an equivalent treatment technology is demonstrated and approved by EPA and Ecology. If availability of required treatment will extend the length of polychlorinated biphenyl waste storage beyond the time allotted to treat and dispose of other Central Waste Complex waste, a variance to the storage prohibition will be applied for in accordance with the procedures detailed in the Tri-Party Agreement (Ecology et al. 1989).

\subsection{RETRIEVABLY STORED LOW-LEVEL AND TRANSURANIC WASTE}

Since 1970, defense materials production, research, and waste management have produced transuranic waste. Before 1970 there were no regulations that defined or required separation of transuranic waste and it was commingled and buried with low-level waste. Initially, the definition of transuranic waste included any waste with suspect alpha contamination. This definition was later (1972) changed to include only waste containing greater than 10 nanocuries per gram of alpha-emitting isotopes with half-lives greater than 20 years; and still later (1982) the definition was changed to include only waste with greater than 100 nanocuries per gram of transuranic radionuclides. Transuranic radionuclides are those having an atomic number greater than 92 . Because existing technology in the 1970 s could not determine the concentration of transuranic radionuclides at 10 or even 100 nanocuries per gram, any solid waste that was suspected to be transuranic was placed in retrievable storage (WHC 1990j).

Retrievably stored low-level waste is waste that was generated after 1980 and before 1988, when use of retrievable storage units was terminated. The waste contained liquid organics that precluded disposal as solid low-ievel waste because of concerns about affecting the ion exchange capacity of the soil. This waste is stored in retrievable storage units in the same manner as retrievably stored transuranic waste. 
The retrievably stored waste at the Hanford Site was not segregated based on the physical or chemical characteristics of the waste. The waste containers are filled with mixtures of materials such as failed process equipment including pumps, resin columns, and tanks; laboratory and room trash ilcluding paper, plastics, glassware, cloth, solidified liquids, and animal carcasses; and decontamination and decommissioning rubble including concrete, piping, and soils.

The waste is contained primarily in 0.21-cubic-meter drums and metal or wood boxes. Waste also is contained in casks, concrete boxes, concreted culverts, and other miscellaneous containers.

Before 1986, transuranic waste had been placed in a variety of storage configurations. These storage configurations consisted of shallow land trenches, concrete-lined " $V$ " trenches, and earth-covered asphalt pads and caissons (WHC 1990g). The transuranic waste has been stored in the Transuranic Storage and Assay Facility (TRUSAF) since 1986 (Section 4.15) and in the Central Waste Complex since 1988 (Section 4.13).

The majority of the transuranic waste stored in the 200 Areas is generated by onsite activities; however, some of the transuranic waste is generated offsite and shipped to the Hanford Site for retrievable storage (RHO 1985). As of January 1989, approximately 15,000 cubic meters of transuranic waste has been placed in storage in the 200 Areas in over 38,700 containers. Of this volume, 291 cubic meters are known to je transuranic mixed waste.

\subsubsection{Generation}

Extensive process knowledge is not available for many of the containers that have been placed in retrievable storage. The best available information is maintained in the computerized Richland Solid Waste Information Managenent System database. The Richland Solid Waste Information Management System contains only that information provided by the waste generator. In the past, exhaustive waste descriptions that could be used to classify a waste accurately were not required and data entries such as "contaminated debris" and "mixed fission products" were common (WHC 1990j). Data from Richland Solid Waste Information Management System indicate that about $2.5 \%$ of the transuranic waste is known to be mixed waste. Because of incomplete classification of waste in the past, it is estimated that $10 \%$ of the transuranic waste may be mixed waste.

\subsubsection{Characterization}

This section discusses waste characterization based on process knowledge and sample analysis, tidentifies known designations, and addresses any further characterization required or planned.

4.14.2.1 Process Knowledge. Limited process knowledge has been used to characterize the transuranic mixed waste currently in storage. In the past few years changing waste reporting, manifesting, and packaging requirements have greatly increased the availability of process knowledge for 
characterizing waste. Information related to the physical, chemical, and radiological properties of newly generated transuranic waste is available. This availability is anticipated to reduce the amount of sampling and treatment required to meet long-term storage packaging requirements.

4.14.2.2 Sample Analyses. Sampling for mixed waste constituents will be performed when the transuranic waste is retrieved from storage and processed. This sampling will be done in the Waste Receiving and Processing Facility. Any drum or box of transuranic waste that is suspected of containing mixed waste will be opened. Each individual container will be sampled and these samples will be prepared for transport to analytical laboratories in the 200 West Area for analysis.

4.14.2.3 Waste Designation and Basis. A review of the Richland Solid Waste Information Management Syst:em data on transuranic waste in retrievable storage units identified many const:ituents in each waste container that are designated dangerous waste. Data entered since 1988 has the designation of the dangerous constituents of each waste package assigned. When the designation was not found on the Richland Solid Waste Information Management System report, waste designation tables were used to assign a designation to the constituents identified in transuranic waste placed in storage before 1988. Table 4-23 summarizes the volume and designation of low-level mixed waste listed on Richland Solid Waste Information Management System in retrievable storage units. Table 4-24 summarizes the volume and designation of transuranic mixed waste listed on Richland Solid Waste Information Management System in retrievable storage units.

It is anticipated that additional transuranic mixed waste will be identified when waste is retrieved from storage for repackaging for disposal (WHC 1990j).

4.14.2.4 Uncertainty of Waste Designation. There is high confidence in the accuracy of the designations for newly generated transuranic waste material. 0lder waste will require additional characterization before treatment and disposal.

4.14.2.5 Schedule for Further Characterization. In situ sampling of retrievably stored transurianic waste will be initiated in fiscal year 1991 with characterization completed by fiscal year 1994 (WHC 1990i). The purpose of the sampling is to assess the current and future integrity of the retrievably stored waste containers and analyze contents. These objectives will be achieved by visual and nondestructive examination of waste containers, retrieval, and nondestructive assay.

Additional sampling will be performed as necessary to adequately characterize suspected mixed waste when waste packages are retrieved and processed through the Waste Receiving and Processing Facility.

\subsubsection{Storage}

This section describes the current storage units and inventories, and assesses compliance with applicable regulations. 
4.14.3.1 Storage Unit and Capacity. The waste stored in the retrievable storage unit is primarily contained in 0.21-cubic meter drums and boxes. Initially drums were painted; however, after 1982, galvanized drums were used to minimize corrosion attributed to high humidity in storage modules.

Initially boxes were constructed of plywood and steel, later of plywood coated with fiberglass reinforced polyester, and currently of constructed using steel. Waste also is contained in casks, concrete boxes, concreted culverts, and other miscellaneous containers. These containers were placed in a variety of storage configurations. These storage configurations consisted of shallow land trenches, concrete lined " $V$ " trenches, and earth-covered asphalt pads and caissons (WHC 1990g) (Figures 4-19 and 4-20).

Retrievably stored transuranic waste is located in the $218-W-3 A,-4 B$, $-4 C$, and 218-E-12B burial grounds. Newly generated (after 1985) transuranic waste is and will be stored in the TRUSAF and Central Waste Complex storage buildings.

Four different container storage configurations were used for contacthandled transuranic waste at the Hanford Site. The first storage configuration consists of waste drums stacked horizontally in a gravel-bottom "V" trench. The waste drums were covered directly with soil. This storage configuration was used from 1970 through 1972.

The second storage configuration was an engineered concrete and metal storage structure known as the $V-7$ trench. In the $V-7$ trench, drums were stacked on a 45-degree angle. This storage concept proved too expensive to implement and was used only between June 1972 and March 1973.

The third configuration consists of wide bottom and " $V$ " trenches. In both cases the trench floor was covered with plywood, and drums were stacked vertically (Figure 4-19). Fire retardant plywood was placed between layers of drums and on top of the drums. The drums in wide-bottom trenches were stacked in modules 12 drums wide by 12 long by 4 to 5 high. Each module was covered with a plastic tarp. Vent (air circulation or riser) pipes of 0.6-meterdiameter poly vinyl chloride were placed in the middle of each module from the trench bottom to 1.8 meter above the soil surface in an attempt to reduce humidity ithin the storage module. This siorage configuration was used in the 200 West 218-W $3 A$ and 218-W 4B Burial Gruunds from 1974 unt,il the present.

The fourth configuration consists of wide-bottom trenches. This storage configuration is the same as the third except the floor is asphalt rather than plywood. This storage configuration was used in 218-W-4B trench 07 from 1974 until 1980 and in the 218-W-4C Burial Ground from 1978 to the present.

Remotely handled transuranic waste is stored in buried caissons; these caissons no longer are used for newly generated waste. The caissons are reinforced concrete cylinders 2.7 meters in diameter by 3 meters high and are buried 4 meters belowgrade. The caissons have 0.9-meter diameter inlet chutes, offset or convoluted to eliminate radiation or 'shine' from the contents (Figure 4-20). Caissons are equipped with electrically driven exhausters fitted with high-efficiency particulate air filters. 
Because the practice of placing transuranic waste in burial ground retrievable storage units was discontinued in 1986, and no additional waste is planned to be added, the storage capacity for this waste is adequate.

4.14.3.2 Amount in Storage. As of January 1989, approximately 15,440 cubic meters of waste have been $\mathrm{placed}$ in storage in the 200 Area retrievable storage units. Of this volume, $2.1 \%$ or 330 cubic meters are known to be dangerous waste based on information contained in the Richland Solid Waste Information Management System Because mixed waste data were not required before 1986, the amount of dangerous waste is underestimated. The Richland Solid Waste Information Management System data from 1986 through 1988 identified $12.4 \%$ of the waste going to the retrievable storage units as mixed waste. Because mixed waste reporting requirements were in place during this time period, it should be indicative of the mixed waste volume. Based on the mixed waste percentage, an additional 1,550 cubic meters may be redesignated as dangerous land disposal restricted waste upon retrieval.

The ani $t$ and classification of land disposal restricted waste known to b. restrict from land disposal stored in retrievable storage units is shown in Tables 4-23 and 4-24.

4.14.3.3 Storage Compiiance Assessment. The retrievable storage units were reviewed for compliance with interim-status dangerous waste regulations during 1988. This section discusses past and present disposal practices and discusses the interim status compliance requirements.

Waste was placed routinely in the retrievable storage units in shallow unlined trenches since 1960. From 1982 through 1987, radioactive 1iquid organic waste was placed in retrievable storage units. Burial of mixed waste with dose rates less than 200 millirems per hour at the container surface was halted in 1987. After the existing burial trenches are filled, mixed waste will be placed in lined trenches with leachate collection and removal systems. The transuranic mixed waste eventually will be retrieved, treated to comply with land disposal restriction requirements at the Waste Receiving and Processing Facility or other appropriate treatment unit, and disposed of at a permitted dangerous waste disposal .nit.

The compiiance assessment noted the following specific areas of noncompliance with interim status requirements.

- The contingency plan should be upgraded to account for unit requirements of dangerous waste management.

- A plan to inspect mixed waste placed in retrievable storage units should be developed.

- Dangerous waste containers and accessible mixed waste backlog should be labeled.

- A burial box, and cardboard compaction and segregation strategy should be developed. 
- Additional groundwater monitoring wells around the low-level burial grounds, which include the retrievable storage units, should be installed.

Compliance action schedules were developed as part of the Tri-Party Agreement (Ecology et al. 1989). Compliance with contingency plan upgrade, inspection and labeling requirements was achieved by June 1990 (DOE/RL 1990f). Usage of cardboard boxes for burial was terminated effective January 1990. Processing facilities for compatible wastes currently are available. Additionally, a total of 51 groundwater monitoring wells were installed by June 1990, and 18 groundwater monitoring wells are planned to be installed by December 1991 .

The Part B permit application, which documents the current compliance status with the dangerous waste regulations, was submitted in December 1989 (Ecology et al. 1989). Therefore, the retrievable storage units comply with the storage unit regulations as modified by the Tri-Party Agreement (Ecology et a1. 1989).

\subsubsection{Treatment}

This section describes the current and proposed treatment of retrievably stored transuranic waste.

4.14.4.1 Current Treatinent. No waste in retrievable storage units is being treated.

4.14.4.2 Proposed Treatment. Waste from retrievable storage units will be retrieved and shipped to the Waste Receiving and Processing Facility. Organics will be sent offsite for treatment. The purpose of the Waste Receiving and Processing Facility is to treat waste so that it is acceptable for permanent disposal. Treatment activities include segregation of lowlevel waste and transuranic waste from hazardous waste, repackaging waste, conducting nondestructive examination and nondestructive assaying of packaging, and certifying packages for shipment and disposal.

The Waste Receiving and Processing Facility will be constructed as two modules with Module 1 operations in 1996 and Module 2 operation in 1999. Detailed descriptions of these modules are provided in Section 4.13.4.2.

\subsubsection{Minimization}

The retrievable storage units no longer accept waste; therefore, a waste minimization program is not applicable.

\subsubsection{Variance, Exemptions, Time Extensions}

The waste stored in the retrievable storage units after 1982 is restricted from land disposal because it contains California list waste (40 CFR 268.32) and/or solvent waste (40 CF? 268.30) and/or the Third Third Promulgation. 
The Third Third Promulgation (55 FR 22520) pruvided for a 2-year national capacity variance for mixed waste from the land disposal restrictions. This variance allows continued storage of these wastes. In the event that sufficient treatment capacity for this waste is not available at the expiration of this variance (August 1992), the Tri-Party Agreement will allow continued storage of this waste until sufficient treatment capacity is available in accordance with the schedules in the agreement.

The Tri-Party Agreement (Ecology et a1. 1989) provides for continued storage of California 1ist ( 40 CFR 268.32) and solvent waste (40 CFR 268.30) until treatment capacity is developed for these wastes. The agreement requires treatment and disposal capacity wastes to be developed on the following schedule:

- Completion of Waste Receiving and Processing Facility Module I, required to sort and repackage waste and initiation of operations by September 1996 (milestone M-18-00)

- Completion of Waste Receiving and Processing Facility Module II, required to provide waste treatment capabilities that minimize the land disposal of low-level radioactive and mixed waste by September 1999 (milestone M-19-00).

If additional variances, exemptions, or extensions of time are required as a result of delays in the development of treatment, storage, id disposal capacity or the demonstrated need for using alternative treatment technologies, they will be applied for in accordance with the procedures detailed in the Tri-Party Agreement (Ecology et al. 1989).

\subsection{TRANSURANIC WASTE STORAGE AND ASSAY FACILITY STORED WASTE}

Transuranic solid waste packaged in compliance with the Waste Isolation Pilot Plant/Waste Acceptance Criteria is stored in the 200 West Area, in the 224-T Building, also known as the TRUSAF.

\subsubsection{Generation}

This section describes the waste generation process and estimates the generation rate.

4.15.1.1 Process. The following are descriptions of current sources of transuranic mixed waste:

- The PUREX Plant reprocesses irradiated fuel from the $N$ Reactor. Radioactive solid waste is collected from all parts of the PUREX Plant, including the laboratory. The transuranic portion is separated from the low-level waste. Some of the waste, such as mercury-filled light tubes, rags, and aerosol cans, are definitely dangerous and separate collection receptacles are established for collection of this waste. To ensure that dangerous waste is not inappropriately discarded with the low-level waste or transuranic waste, the waste is sorted before packaging and shipment. 
- The Plutonium Finishing $P l a n t$ routinely generates mixed solid waste. Polychiorinated biphenyl-contaminated radioactive waste is generated by maintenance and periodic flushing of polychlorinated biphenyl hydraulic systems and removal of polychlorinated biphenyl ballasts from light fixtures. Fluorescent light tubes containing mercury are used in processing gloveboxes and radiation areas throughout the Plutonium Finishing Plant. The majority of polychlorinated bipheny ballasts and fluorescent light tubes are surveyed for radiological contamination and released. These wastestreams are handled as hazardous waste. A small portion of the ballasts and fluorescent light tubes are radiologically contaminated and must be treaicd as mixed waste. Lead-lined gloves on processing gloveboxes are routinely replaced to minimize the potential for glove failure and subsequent spread of radioactive contamination. Approximately 15 drums of lead glove waste is generated each year at the Plutonium Finishing Plant. Laboratory waste containing $x y l e n e$ and toluene are generated during the analysis of samples for neptunium and plutonium. The waste is packaged and shipped as solid waste.

- Operations of the analytical laboratories in 200 West Area generate mixed waste that is potentially transuranic. Included in this solid waste is radioactively contaminated lead, outdated solid commercial chemicals, and lead shielded waste from laboratory hot-cell operations.

- Pacific Northwest Laboratory generates small quantities of transuranic mixed waste from research operations which are fully characterized by process knowledge.

4.15.1.2 Generation. The TRUSAF receives some containers of waste from offsite. These containers are sent to TRUSAF for storage before shipment to the Waste Isolation Pilot PIant. The projected generation for TRUSAF waste is included with Central Waste Complex. The TRUSAF only accepts waste certified for disposal at the Waste Isolation Pilot Plant packaged in 0.21-cubic meter drums. Presently, projected generation rates of transuranic waste that meet TRUSAF storage criteria are unavailable.

\subsubsection{Characterization}

This section discusses waste characterization based on process knowledge and sample analysis, identifies known designations, and addresses any further characterization required or planned.

To be accepted at TRUSAF, waste must be packaged and characterized as described in Hanford Site Radioactive Solid Waste Acceptance Criteria. These criteria require that the generator of the waste characterize each individual container of waste with sufficient accuracy to permit proper segregation, treatment, certification, shipment, and storage. Kinds and quantities of dangerous constituents in the waste, and physical and chemical characteristics of the waste must be known and recorded on appropriate forms.

4.15.2.1 Process Knowledge. The waste characteristics are determined by the waste generator based on documented knowledge of the process generating the 
waste. The generators of all waste shipped to TRUSAF is periodically audited to ensure that waste is being properly characterized. Currently, only two facilities (PUREX and Plutonium Finishing Plant) are able to certify waste.

4.15.2.2 Sample Analyses. Samples are collected at the point of generation for any sample analysis required to adequately characterize for waste designation. No samples are collected at TRUSAF. Any waste which requires sampling will not be certified and consequently will be shipped to Central Waste Complex for storage and subsequent treatment.

4.15.2.3 Waste Designation and Basis. The dangerous waste designation of each container of waste is determiged at its point of generation based on knowledge of the waste placed in the container. The waste code designations and volumes are listed in Table 4-25.

4.13.2.4 Uncertainty of Waste Designation. The designations of waste stored in TRUSAF are considered to be accurate.

4.15.2.5 Schedule for Further Characterization. Waste in interim storage is certified and are awaiting shipment to the Waste Isolation Pilot Plant. No further characterization is required for this waste.

\subsubsection{Storage}

This section addresses current storage units, describes inventories and assesses compliance with applicable regulations.

4.15.3.1 Storage Unit and Capacity. The TRUSAF building was originally constructed to purify plutonium nitrate by the lanthanum fluoride process; it was idle for several years after new technology made it obsolete. In the early 1970s, the building was modified to meet requirements for storage of plutonium-bearing scrap and liquids. The cells in the processing areas have been sealed completely and isolated from the operating gallery and service areas. These operating and service areas have been stripped of all unnecessary control equipment, panelboards, and partitions to provide approximately 1,068 square meters of storage space on three floors (Figure 4-21). The unit storage capacity is 420 cubic meters $(2,000$ drums) (DOE/RL 1988).

Accumulation of certified transuranic waste in 0.21 -cubic meter drums that exceeds the capacity of TRUSAF will be stored in Central Waste Complex. Future plans for Central Waste Complex include a TRUSAF replacement to be called the Moderate Hazard Storage Facility, which will be operational concurrently with the Waste Receiving and Processing Facility Module I.

4.15.3.2 Amount in Storage. Table 4-22 summarizes the volume of each designated transuranic mixed waste listed on Richland Solid Waste Information Management System stored in TRUSAF.

4.15.3.3 Storage Compliance Assessment. The TRUSAF unit was reviewed for compliance with interim status dangerous waste regulations during 1988 . The need for an upgraded contingency plan was identified and completed by June 1990 (DOE/RL 1990a). 
DOE/RL-90-41

A Part $B$ permit application will be submitted in June 1992 demonstrating compliance with final facility regulations.

\subsubsection{Treatment}

This section describes the current and proposed treatment of stored transuranic waste.

4.15.4.1 Current Treatment. At TRUSAF, packaged transuranic waste is $x$-rayed (to ensure what can be identified generally agrees with the documentation) and assayed to determine transuranic activity. Al1 transuranic waste packages that meet the Waste Isolation Pilot Plant/Waste Acceptance Criteria requirements are placed in interim storage pending shipment to the Waste Isolation Pilot Plant. Noncertifiable transuranic waste is sent to the Hanford Central Waste Complex. When the Waste Receiving and Processing Facility Module I begins operating, nondestructive evaluation and assay activities will be transferred from TRUSAF to the Waste Receiving and Processing Facility.

4.15.4.2 Proposed Treatment. Certified transuranic waste in TRUSAF interim storage will be shipped to the Waste Isolation Pilot Plant for permanent storage.

\subsubsection{Waste Minimization}

All plants and processes that generate waste that is shipped to TRUSAF are required to have a waste minimization program in place. The effectiveness and implementation of this program is audited on a regular basis. The following are key elements of these programs:

- To the extent practical, all mixed waste is segregated and packaged separately from low-level waste or transuranic waste that contains no hazardous or dangerous constituents.

- The total volume of mixed waste generated is minimized to the extent possible by segregation, compaction, and consolidation.

- To minimize the generation of mixed waste, generators actively seek nondangerous alternatives for the dangerous constituents in their processes.

- If allowed by regulation, mixed waste is treated to remove the dangerous constituents.

- Corrosive materials are neutralized (if allowed by regulation) to remove their corrosive character or packaged in a manner to ensure integrity of the containment barriers.

\subsubsection{Variances, Exemptions, Time Extensions}

The waste stored at TRUSAF is restricted from 1 and disposal because it contains solvent waste ( 40 CFR 268.30) or by the Third Third Promulgation 
(55 FR 22520). The Third Tirird Promulgation (55 FR 22520) provided for a 2-year national capacity variance from the 1 and disposal restrictions for mixed waste. This variance allows continued storage of these wastes. In the event that sufficient treatment capacity for this waste is not available at the expiration of this variance (August 1992), the Tri-Party Agreement will allow continued storage of this waste until sufficient treatment capacity is available in acrordance with the schedules in the agreement.

The Tri-Party Agreement (Ecology et a1. 1989) provides for continued storage of California list ( 40 CFR 268.32) and solvent waste (40 CFR 268.30) until treatment capacity is developed for these wastes.

If additional variances, exemptions, or extensions of time are required as a result of delays in the development of treatment, storage, or disposal capacity, they will be applied for in accordance with the procedures detailed in the Tri-Party Agreement (Ecology et a1. 1989).

\subsection{3-K STORED WASTE}

The 303-K Radioactive Mixed-Waste Storage Facility (303-K Facility) is located in the northwest portion of the 300 Area of the Hanford Site. Since 1943, the 303-K Facility has stored various radioactive and dangerous process materials generated by fuel fabrication in the 300 Area (DOE/RL 1990C). The 303-K Radioactive Mixed-Waste Storage Facility has been used for the interim storage of the following mixed wastestreams generated within the 300 Area:

- Spent degreasing solvents

- Heat-treat salts

- Copper fluorozirconate acid crystals

- Zircaloy-2 and beryllium/zircaloy-2 chips and fines

- Metallic lead

- Sludge centrifuge and filter press solids

- Waste acid absorbed by sedimentary opal clay

- Waste acids contaminated with oil

- Waste hydraulic oil containing halogenated hydrocarbons.

Routine waste is no longer being added to the 303-K Facility.

\subsubsection{Generation}

This section describes the waste generation process and estimates the generation rate for the 303-K Facility. The 303-K Facility has been in operation since 1943 and continues today as an interim storage facility for dangerous and mixed waste generated by the fuel manufacturing processing in the 300 Area.

The 303-K Facility has the capacity to store 200 drums that may contain waste designated F001, WTO2, WTO1, D002, D001, D008, WCO1, WPO1, F003, WT03, D006, D007, D005, D004, D009, D011, and WP02.

4.16.1.1 Process. The 303-K Facility has been used since January 1986 for the storage of containers filled with low-level radioactive waste and mixed 
waste generated at other buildings in the 300 Area. The waste that is potentially contaminated with uranium include waste oils and cutting lubricants, concreted waste from the 304 Facility heat-treat salts (quench and beta), salt crystals from the waste-acid tanks in Building 334-A, degreaser solvents, acid absorbed on opal clay, solids from the 313 Building waste-acid treatment process, and waste oils with solvents from uranium machining operations in the 333 Building.

4.16.1.2 Generation. Approximately 50 to 1000.21 -cubic meter drums of waste are accumulated at the 303-K Facility annualiy. The maximum estimated inventory of containerized waste stored inside the 303-K Faciiity at any time was 200 drums or 42 cubic meters of waste.

Waste stored in the 303-K Facility and the approximate annual volumes generated (when fuel was being fabricated) are shown in the following paragraphs:

- Approximately 6,800 kilograms per year of spent degreasing solvents (F001, WCO1, WPO1, and WTO1) and occasionally mixed with ethyl acetate (D001, F003, and WTO2). Waste solvents were sor times acidic and are corrosive (D002) and have contained TCLP toxic cadmium (D006).

- Approximately 36,000 kilograms per year of heat-treated salts contaminated with naturally occurring radioactive potassium-40. The heat treat salts were generated from both beta bath $(18,000$ kilograms per year) and quench bath (18,000 kilograms per year). The beta bath salts consist of potassium chloride and sodium chloride, which are toxic dangerous wastes (WTO2) and contain TCLP toxic chromium (D007). The quench bath salts consisted of potassium chloride and sodium chloride. The quench bath salts are toxic extremely hazardous wastes (WTO1), and ignitable (DOOI) due to the solid nitrates and nitrites (oxidizers), and contain TCLP toxic barium (D005) and cadmium (D006).

- Approximately 770 kilograms of copper fluorozirconate acid crystals from the bottom of the waste acid tanks. The crystals are corrosive (D002).

- Approximately 2,300 ki lograms per year of zircaloy-2 and beryllium/zircaloy-2 chips and fines before and after concreting the waste. This material is designated ignitable (0001) because of its pyrophoric properties.

- Approximately 2,500 kilograms per year of TCLP toxic metallic lead (D008).

- Approximately 136,000 kilograms per year of centrifuge and filter press sludge designated as a dangerous waste (WT02) by the mixiure rule and an oxidizer (DOO1) because of the solid nitrates. The waste also may contain the TCLP toxic ions introduced into the 300 Area Waste Acid Treatment System. The TCLP toxic ions consist of arsenic (D004), bariı!n (D005), cadmium (D006), chromium (D007), mercury (D009), and silver (D011). 
- Approximately 680 kilograms per year of waste acid is absorbed by sedimentary opal $\mathrm{clay}$ and is designated corrosive (D002). This waste a) so contains TCLP toxic chromium (D007).

- Approximately 27 kilograms per year of waste acids contaminated with oil are designated as corrosive (DOO2) and contain TCLP toxic arsenic (D004), chromium (D007), and silver (D011).

- Approximately 90 kilorrams per year of waste hydraulic oil. This waste contains halogenated hydrocarbons that are designated as a dangerous waste (WPO2).

\subsubsection{Characterization}

The 303-K Facility received a variety of chemical and radiological waste that was generated by fuels manufacturing in the 300 Area. The waste includes neutralized solids, salts and sludges, spent chlorinated solvents, spent coolant, and waste oils. Waste descriptions are provided in Table 4-26.

4.16.2.1 Process Knowledge. The 303-K Facility received bulk containerized liquid and solid waste from the 304 Concretion Facility, the 334-A Acid Storage Tank Building, the 313 Engineering Hot Laboratory, and the 333 Engineering Metallurgy Laboratory (DOE/RL 1990e).

The 304 Concretion Facility was used from 1971 to 1982 to recycle scrap uranium with zircaloy-2 and copper-silicon alloy chips and fines. These materials were concreted into billet's and transferred to the 303-K Facility for storage before being shipped to Fernald, Ohio for uranium recovery (DOE/RL 1990d).

Beryllium/zircaloy-2 alloy and zircaloy-2 chips and fines were concreted into drums to reduce their ignitability and transferred to the 303-K Facility for storage.

In 1988, spent solvents (consisting of perchloroethylene, 1,1,1trichloroethane, and rinse water from degreasing tanks) were stored at the 303-K Facility and then moved to the 304 Facility for repackaging. Additionally, ethyl acetate-bromine solutions yenerated irom laboratory analysis work associated with uranium were occasionally mixed with the degreaser solvents and stored at the 303-K Facility.

From 1975 to 1990, the 334-A Acid Storage Tank Building stored waste acids generated during fuel fabrication process in the 333 Building (DOE/RL $1990 \mathrm{e})$. The primary chemical constituents generated in the 333 Building included acid crystals ( $\mathrm{HNO}_{3}, \mathrm{HF}, \mathrm{H}_{2} \mathrm{SO}_{4}$ ) and solutions absorbed on opal clays, arsenic ion solutions and associated sludges, barium ion solutions and associated sludges, quench salts $\left(\mathrm{KNO}_{3}, \mathrm{NaNO}_{3}, \mathrm{NaNO}_{2}\right)$, and beta salts $(\mathrm{KCl}$, $\mathrm{NaCl}$ ).

The uranium recovery area in the 313 Building has been used from January of 1975 to 1990 for handling nonrecoverable uranium-bearing waste acids that were neutralized with sodium hydroxice. The neutralized waste siurry was 
later centrifuged and filtered. Solids from the centrifuge and filter press were put in drums and transferred to the 303-K Building for storage.

The 333 Building generated most of the waste treated and/or stored in the 300 Area Waste Acid Treatment System. The $N$ Reactor fuel was fabricated in the 333 Building from the 1960 s until operations were discontinued in December 1986. Recoverable and nonrecoverable uranium-bearing waste acids were generated during component cleaning, acid copper removal, end recessing chemical milling, prebraze cleaning, preweld cleaning, and final bright etch steps.

4.16.2.2 Sample Analysis. No further characterization is scheduled until after treatment at the Waste Receiving and Processing Facility.

4.16.2.3 Waste Designation and Basis. The designations for waste received at the 303-K Facility is based on process knowledge of the fuel fabrication operations in the 300 Area:

- F001, WCO1, WP01, WTO1, D001, F003, WT02, D002, and D006 for spent degreasing solvents

- WT01, D001, D005, D006, D007, and WT02 for heat-treat and quench-bath salts

- D002 for copper fluorozirconate acid crystals

- D001 for zircaloy-2 and beryllium/zircaloy-2 chips and fines

- D008 for TCLP Toxic metallic lead

- WT02, D001 D004, D005, D006, D007, D009, and D0011 for centrifuge and filter-press sludge

- D002 and D007 for waste acid absorbed by sedimentary opal clay

- D002, D004, D007 and D011 for waste acids contaminated with 011

- WP02 for waste hydraulic oil.

4.16.2.4. Uncertainty of Waste Designation. The designations of stored container wastes at the 303-K Facility are considered to be accurate.

4.16.2.5 Schedule for Further Characterization. Currently there are no pians for further waste characterization at the 303-K Facility.

\subsubsection{Storage}

This section discusses the 303-K Facility waste storage and capacity, identifies stored quantities, and assesses the compliance status of the unit.

4.16.3.1 Storage Unit Capacity. The 303-K Facility has a total storage capacity of 200 drums or 42 cubic meters of waste. 
4.16.3.2 Amount in Storage. The amount of containerized waste currently in storage in the $303-K$ Facility is $20,868 \mathrm{kilograms}$ (DOE/RL 1989a). No future waste is scheduled for storage at the unit with the exception of waste stored for less than 90 days.

4.16.3.3 Storage Compliance Assessment. The 303-K Facility currently is scheduled for clean closure with an interim use as a less-than-90-day accumulation unit. The unit currently is operating under interim status as a RCRA treatment, storage, and disposal facility.

\subsubsection{Treatment}

This section discusses the 303-K Facii.ty current and proposed waste treatment processes.

4.16.4.1 Current Treatment. The waste currently stored at the 303-K Facility is transferred to the Central Waste Complex for long-term storage until a final disposal option for the waste is established.

4.16.4.2 Proposed Treatment. Current plans for the existing inventories of waste products at the 303-K Facility call for eventual treatment at the Waste Receiving and Processing Facility beginning in 1999. Organics will be sent offsite for treatment. Based on the designated waste codes, each of the 303-K wastes will require one or more of the following corresponding treatments:

- Constituent concentration and waste extraction

- Deactivation

- Macroencapsulation

- Amalgamation

- Reduction.

\subsubsection{Minimization}

This section discusses the 303-K Facility current and proposed waste minimizativii oractices.

4.16.5.1 Current Waste Minimization Practices. Because N Reactor fuel is no longer being fabricated, the 303-K Facility no longer receives waste products for long-term storage.

4.16.5.2 Proposed Waste Minimization Practices. The containerized waste products stored at the 303-K Facility are to be transferred to the Central Waste Complex for interim storage until the final disposal alternative for the waste has been established. The current option of choice is to process the waste at the Waste Receiving and Processing Facility for application of suitable treatments such as reducing volume, reducing toxicity, or recharging. 


\subsubsection{Variances, Exemptions, Time Extensions}

The dangerous waste and waste residues are being placed in containers and transported to the Central Waste Complex for storage, as discussed in Section 4.16.3. This waste will be managed with other Central Waste Complex stored waste.

The waste stored at the 303-K Facility is restricted from land disposal because it contains solvent waste (40 CFR 268.30) and by the Third Third Promulgation (55 FR 22520). The Third Third Promulgation (55 FR 22520) provided for a 2-year national capacity variance from the land disposal restrictions for mixed waste. This variance allows continued storage of these wastes. In the event that sufficient treatment capacity for this waste is not available at the expiration of this variance (August 1992), the Tri-Party Agreement will allow continued storage of this waste until sufficient treatment capacity is available in accordance with the schedules in the agreement.

The Tri-Party Agreement (Ecology et al. 1989) provides for continued storage of California list (40 CFR 268.32) and solvent wasio (40 CFR 268.30) until treatment capacity is developed for these wastes.

If additional variances, exemptions, or extensions of time are required as a result of delays in the development of treatment, storage, or disposal capacity, they will be applied for in accordance with the procedures detailed in the Tri-Party Agreement (Ecology et al. 1989). 


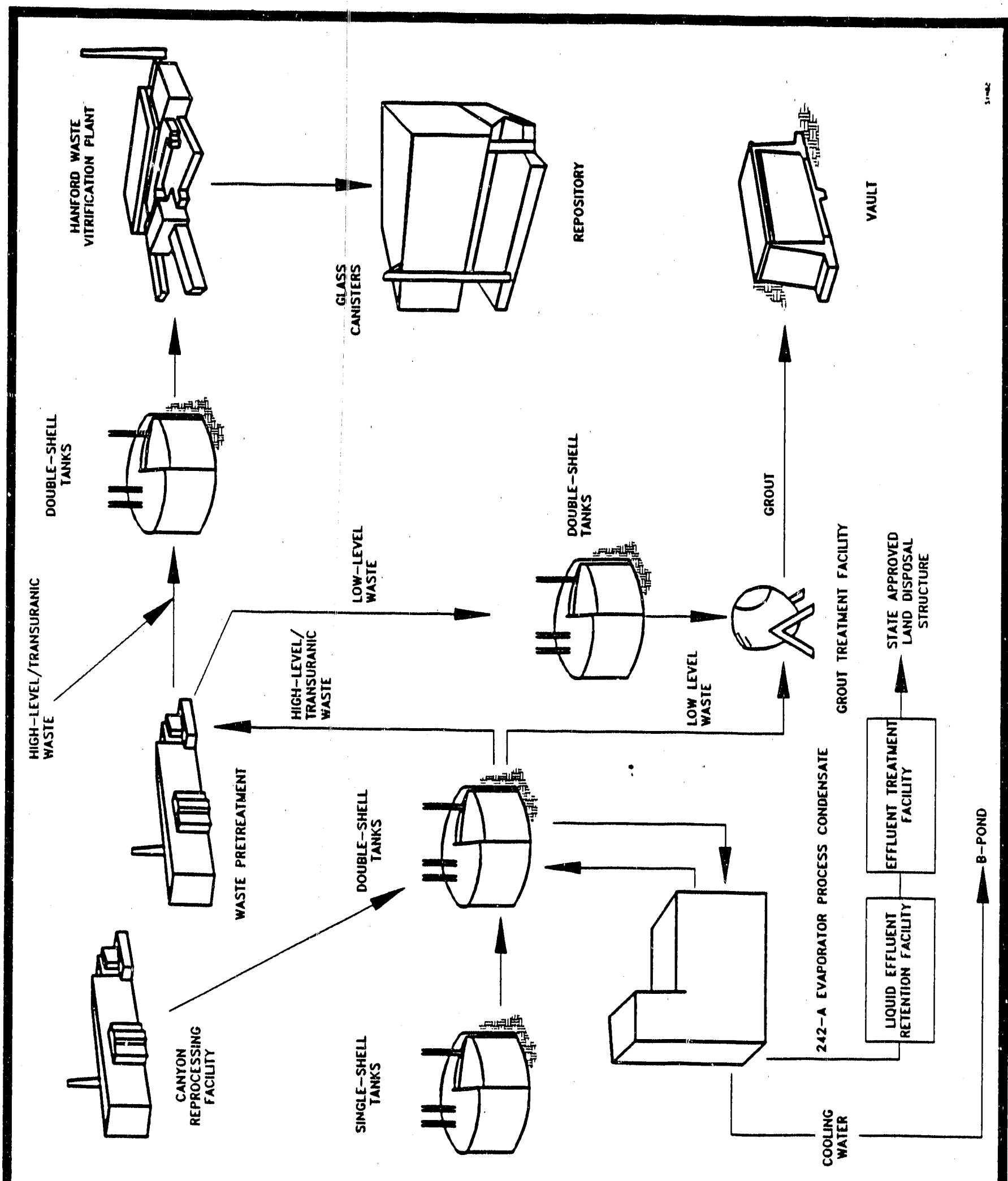

Figure 4-1. Double-Shell Tank Waste Disposal Flow Diagram. 


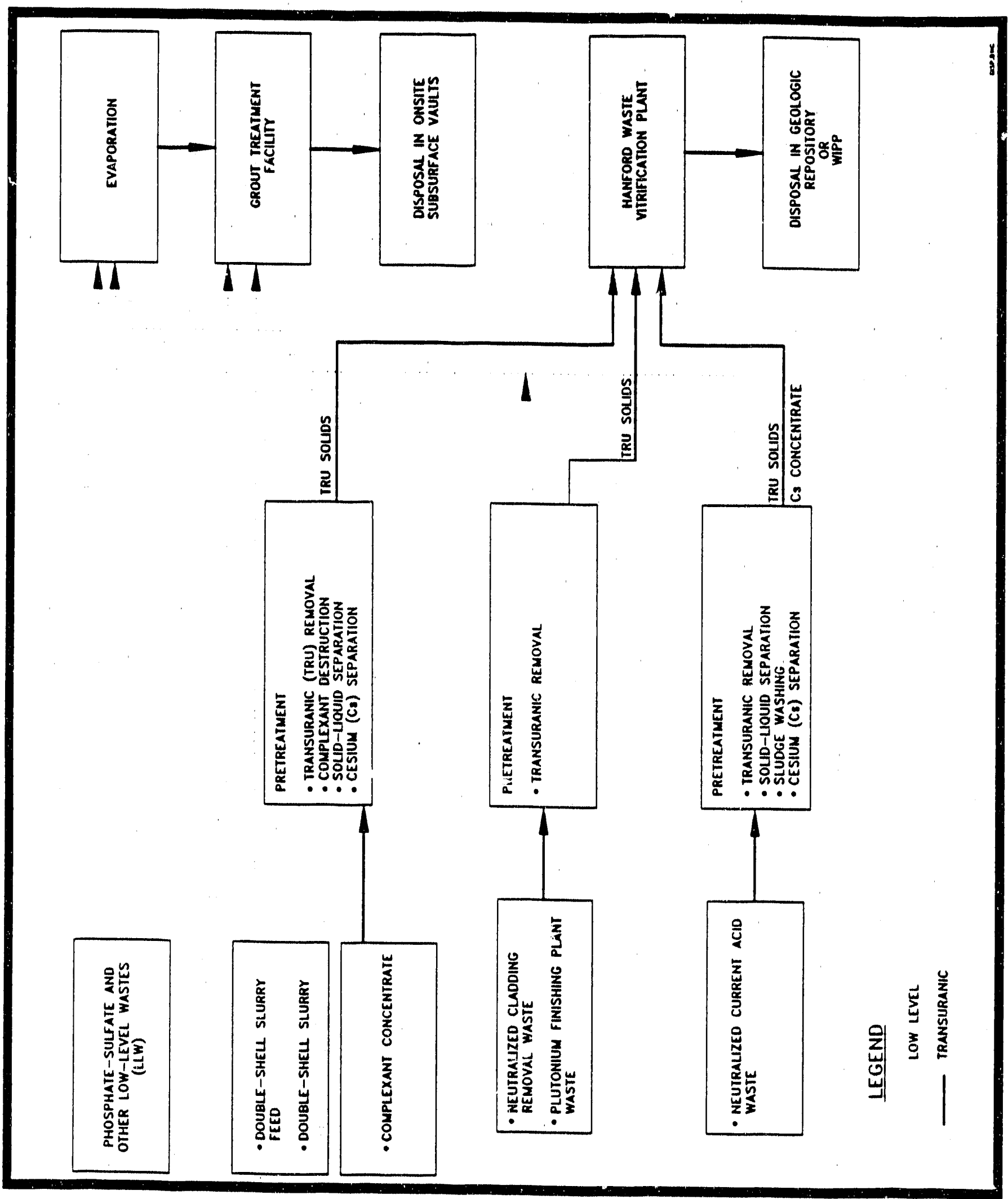

Figure 4-2. Process Flow Diagram for Disposal of Double-Shell Tank Waste F4-2 


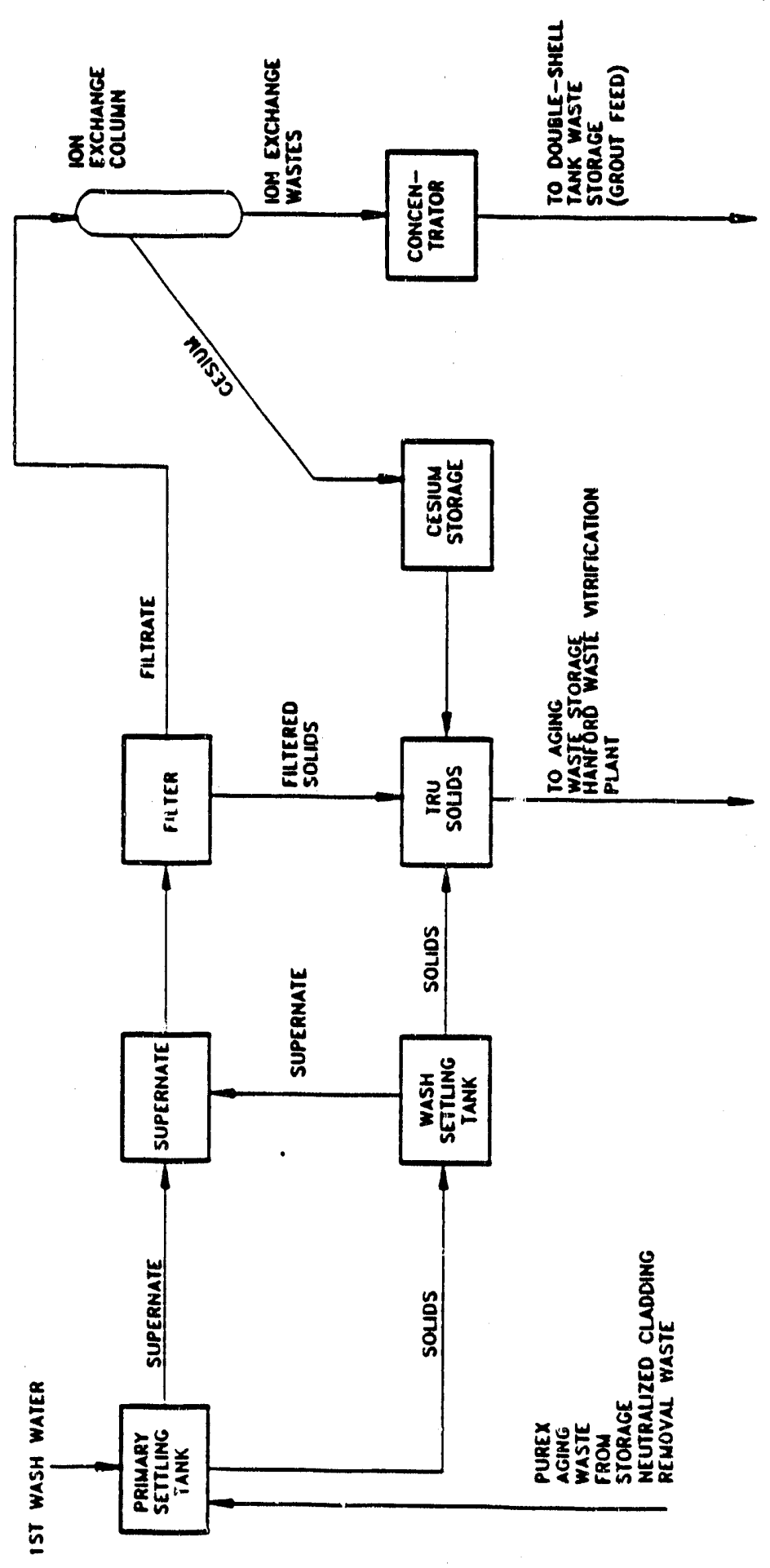

Figure 4-3. Process Flow Diagram for Neutralized Current Acid Waste Pretreatment F4-3 


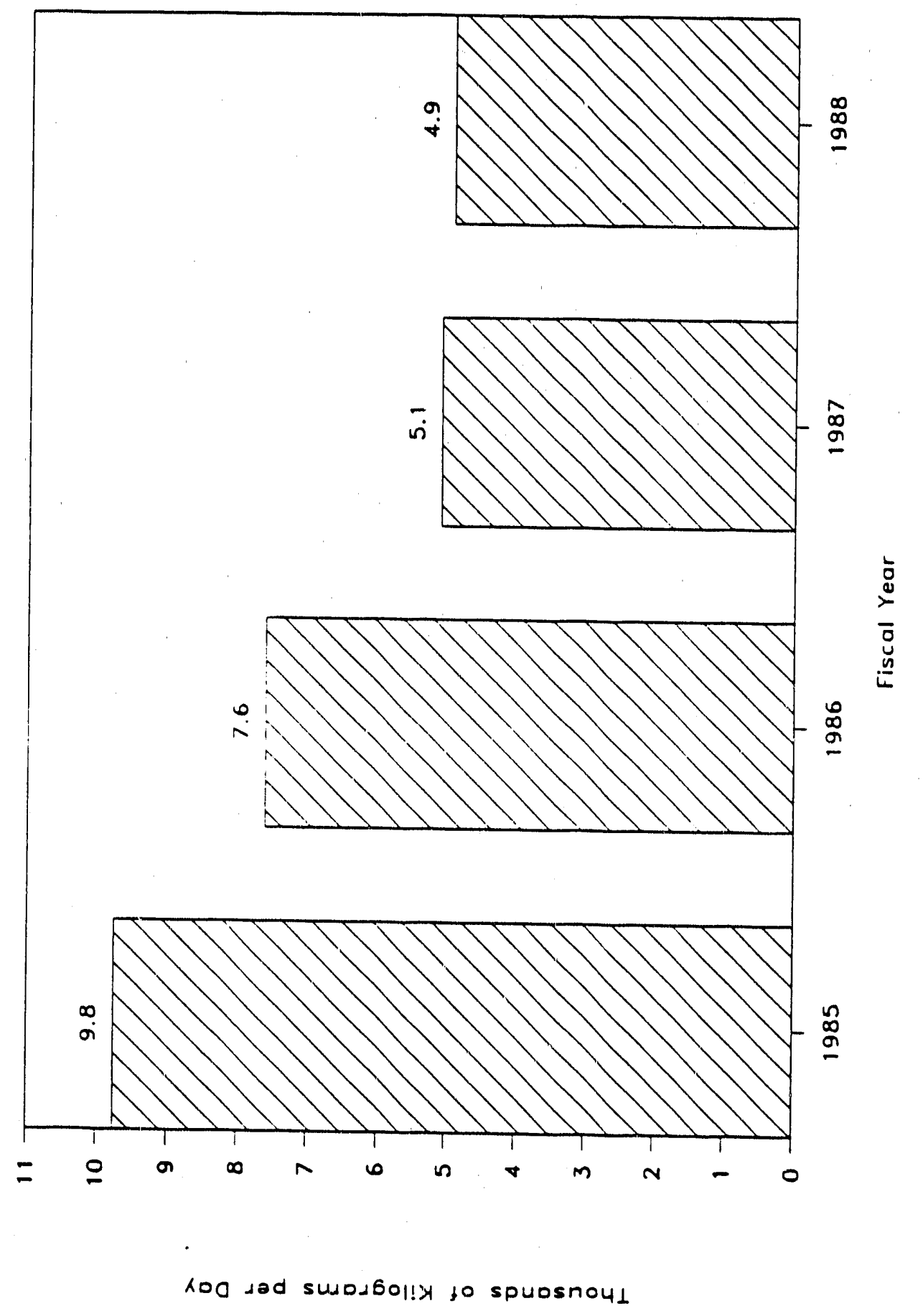

Figure 4-4. PUREX Aging Waste Transfers to Aging Waste Storage F4-4 


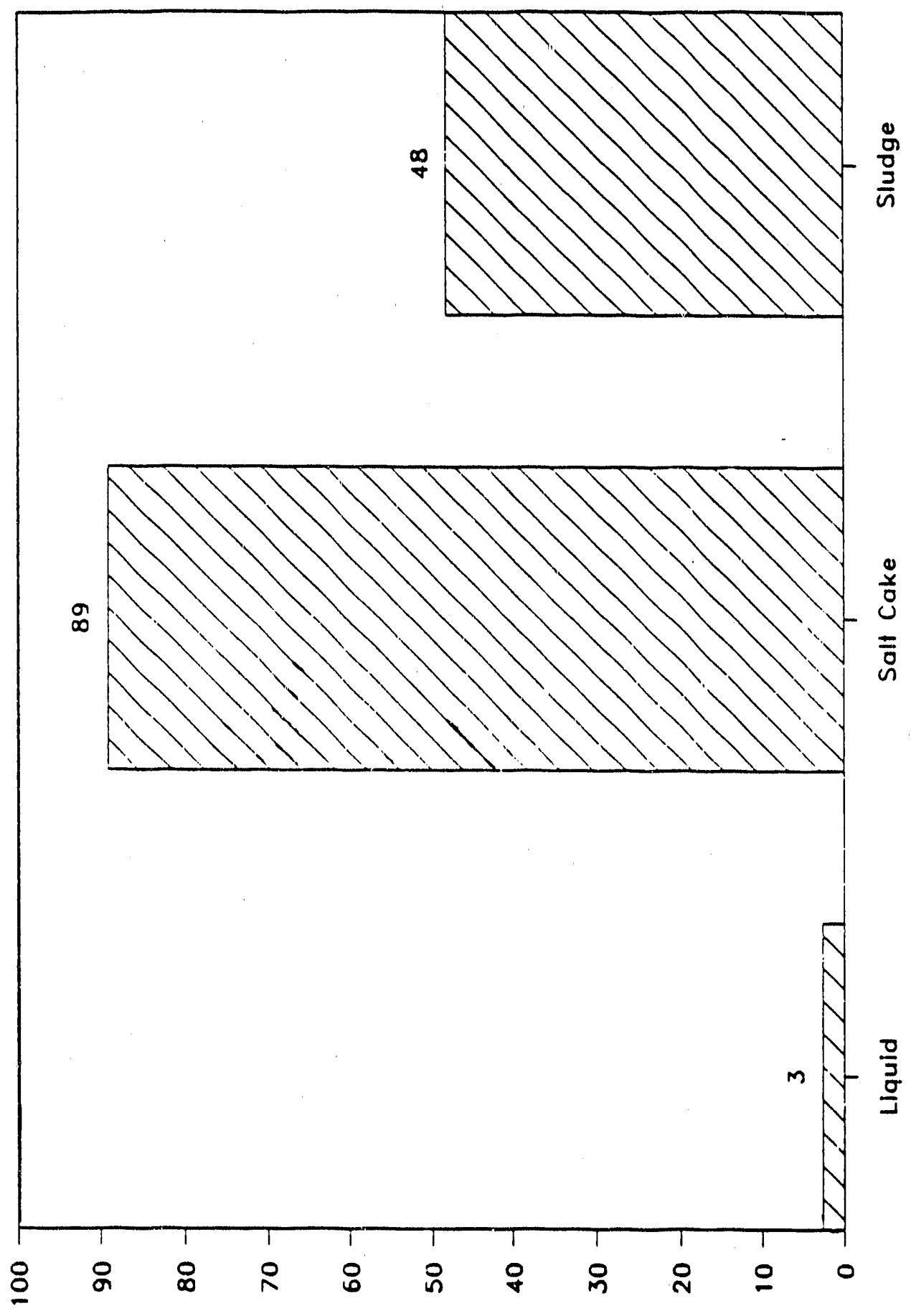

(sjotow signo to spuosnoyl) ownion

Figure 4-5. Relative Proportions of Supernatant, Sludge and Saltcake in Single Shell Waste 


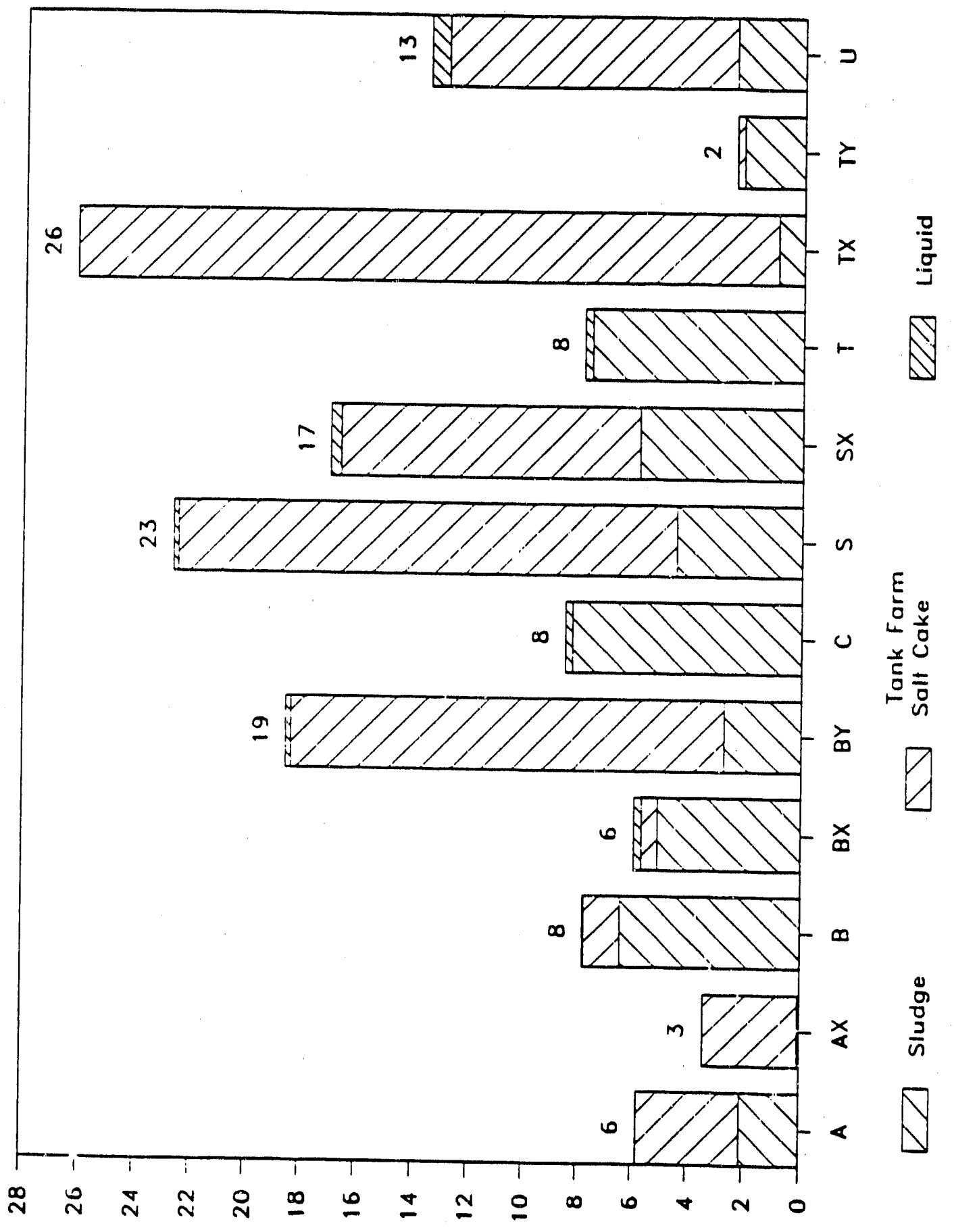

(sjataw ग!qno to spuosnoyl) aunion

Figure 4-6. Single-She11. Tank Waste Inventory by Tank Farm $14-6$ 


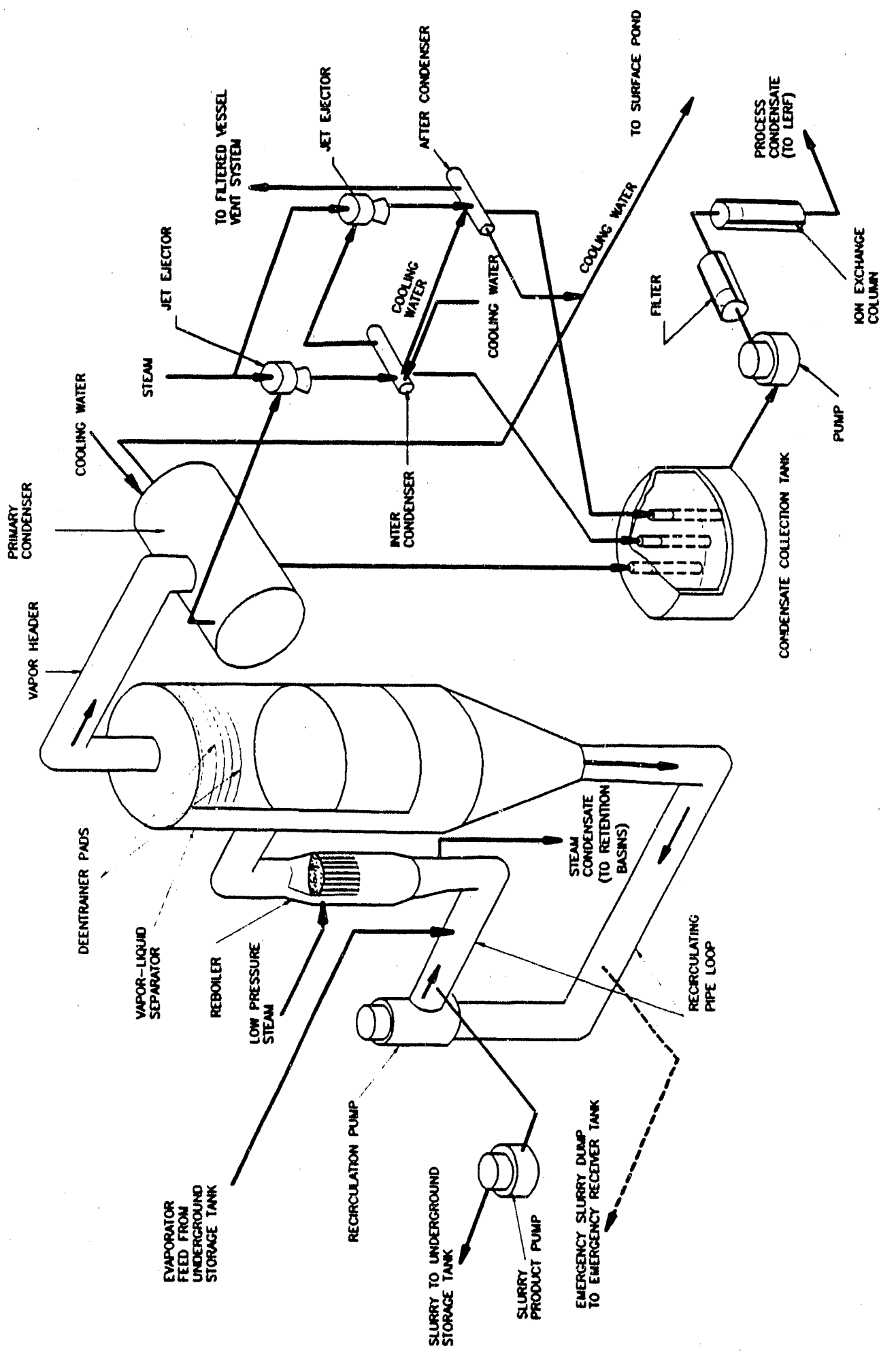

Figure 4-7. Process Flow Diagram for 242-A Evaporator Waste Treatment $F \dot{4}-7$ 


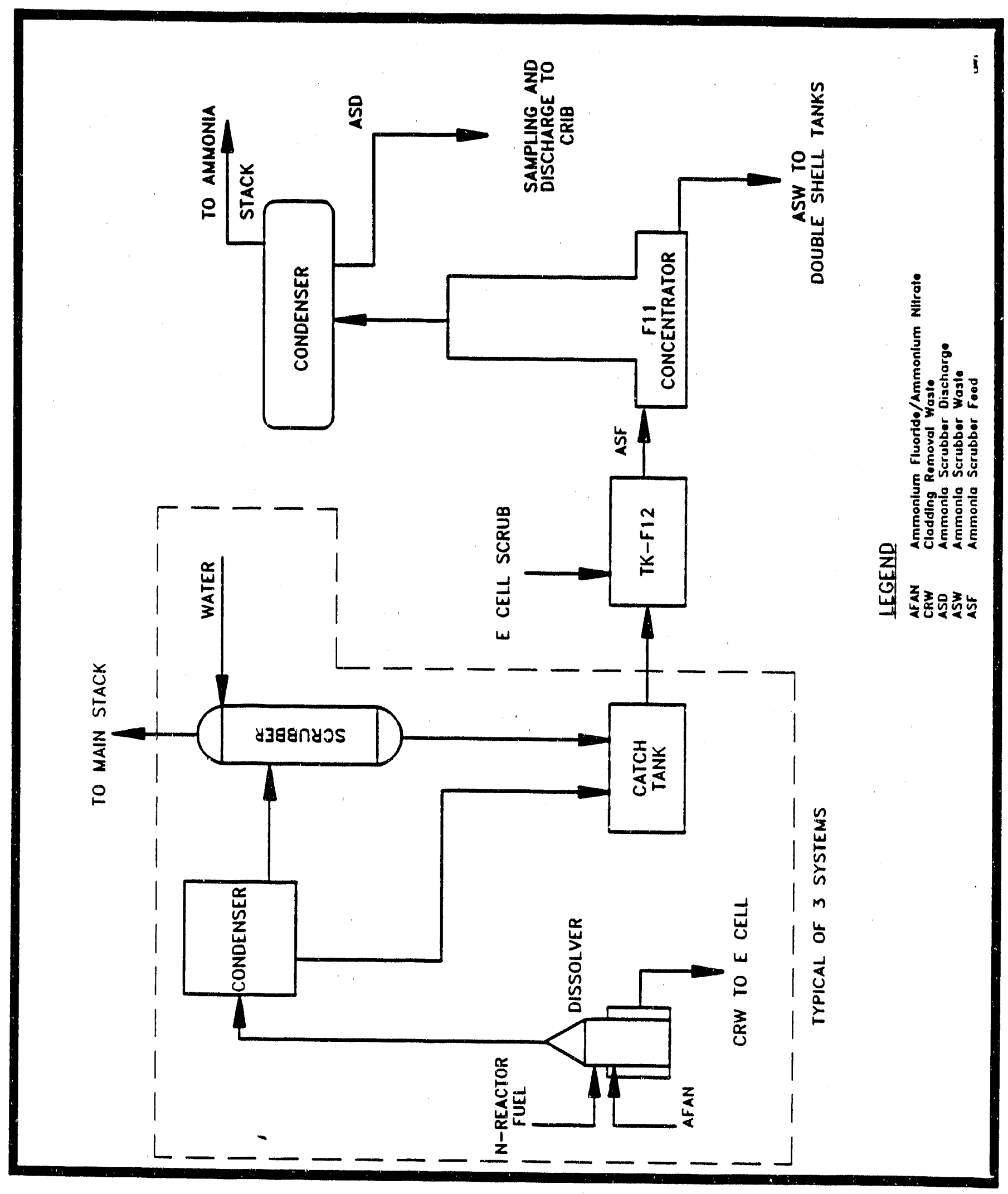

Figure 4-8. Historical Process Flow Diagram for Ammonia Scrubber Waste Generation F4-8 


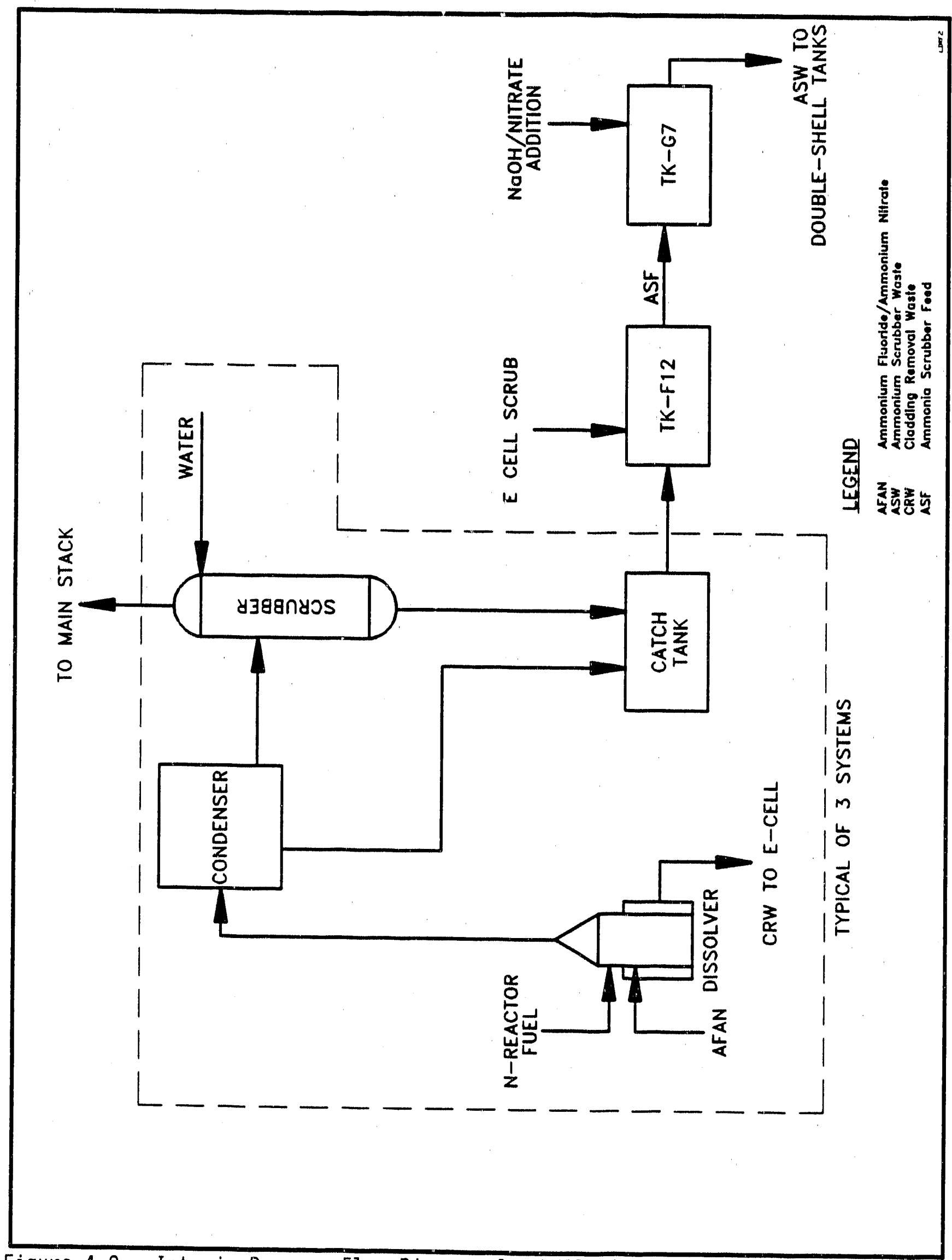

Figure 4-9. Interim Process Flow Diagram for PUREX Ammonia Scrubber Waste Generation F4-9 


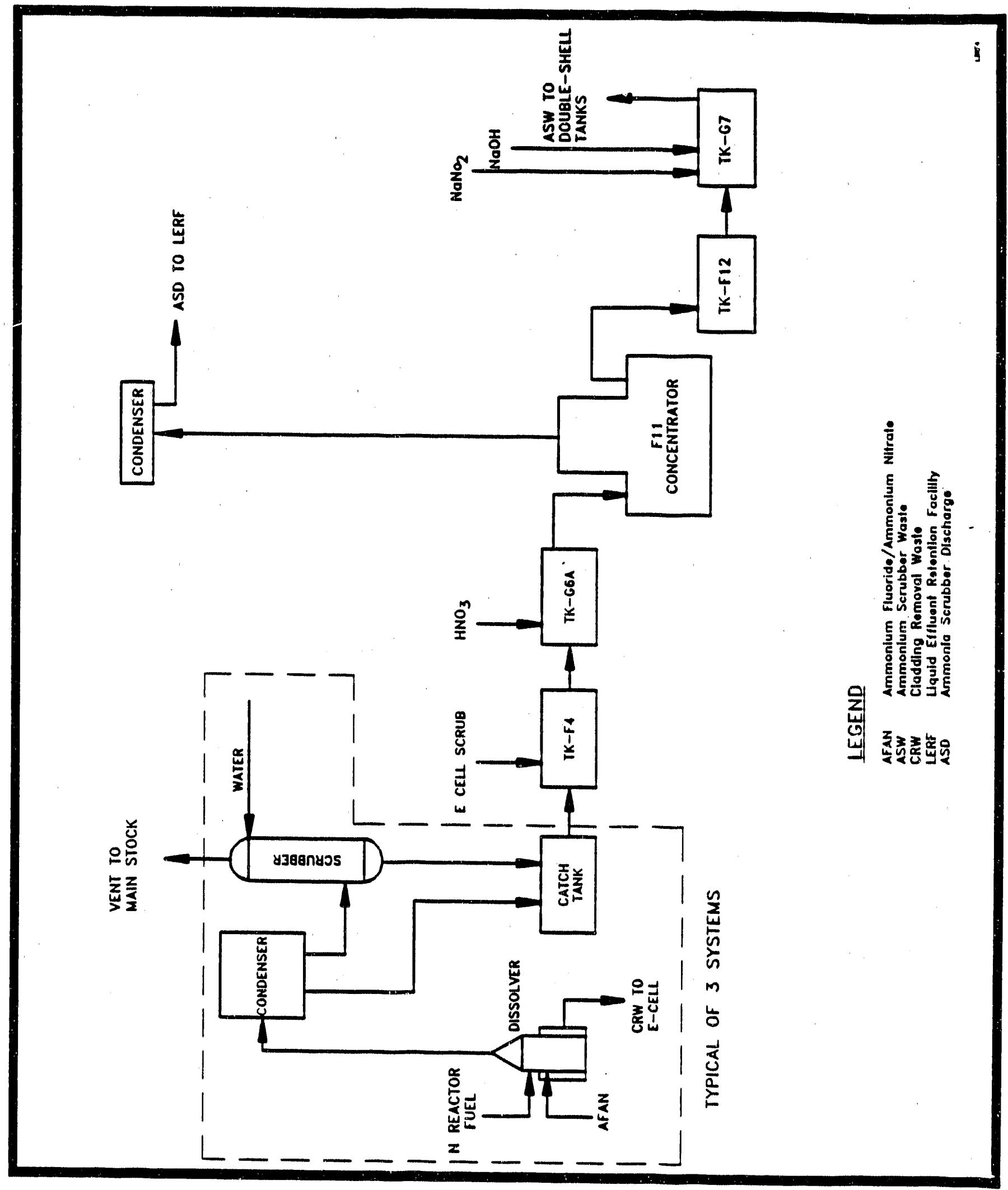

Figure 4-10. Process Flow Diagram for Proposed PUREX Ammonia Destruction Process F4-10 


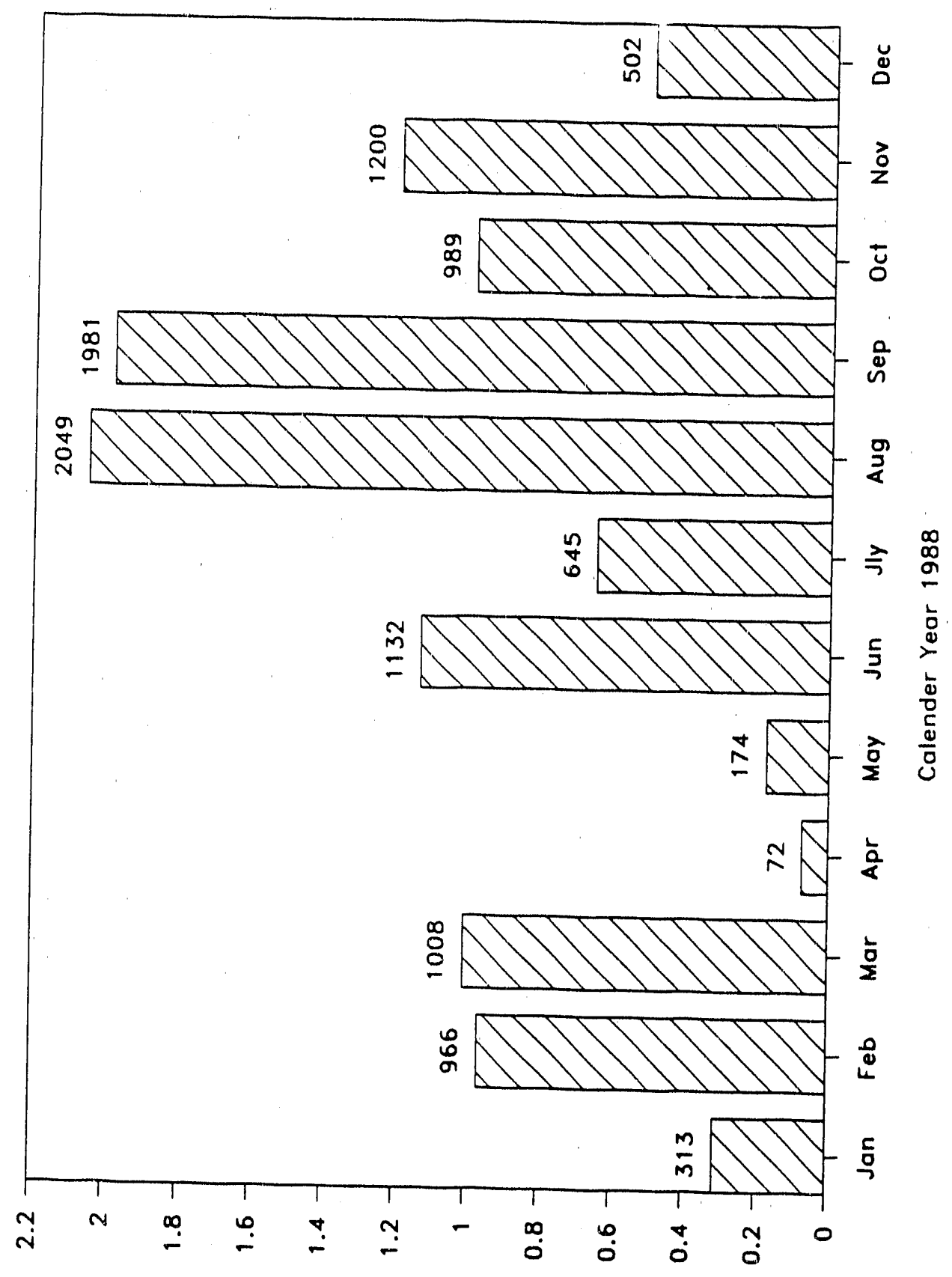

(sjotow ग!qng to spudsnoul) ounion

Figure 4-11 Ammonia Scrubber Waste Transfers to Double-She11 Tanks 


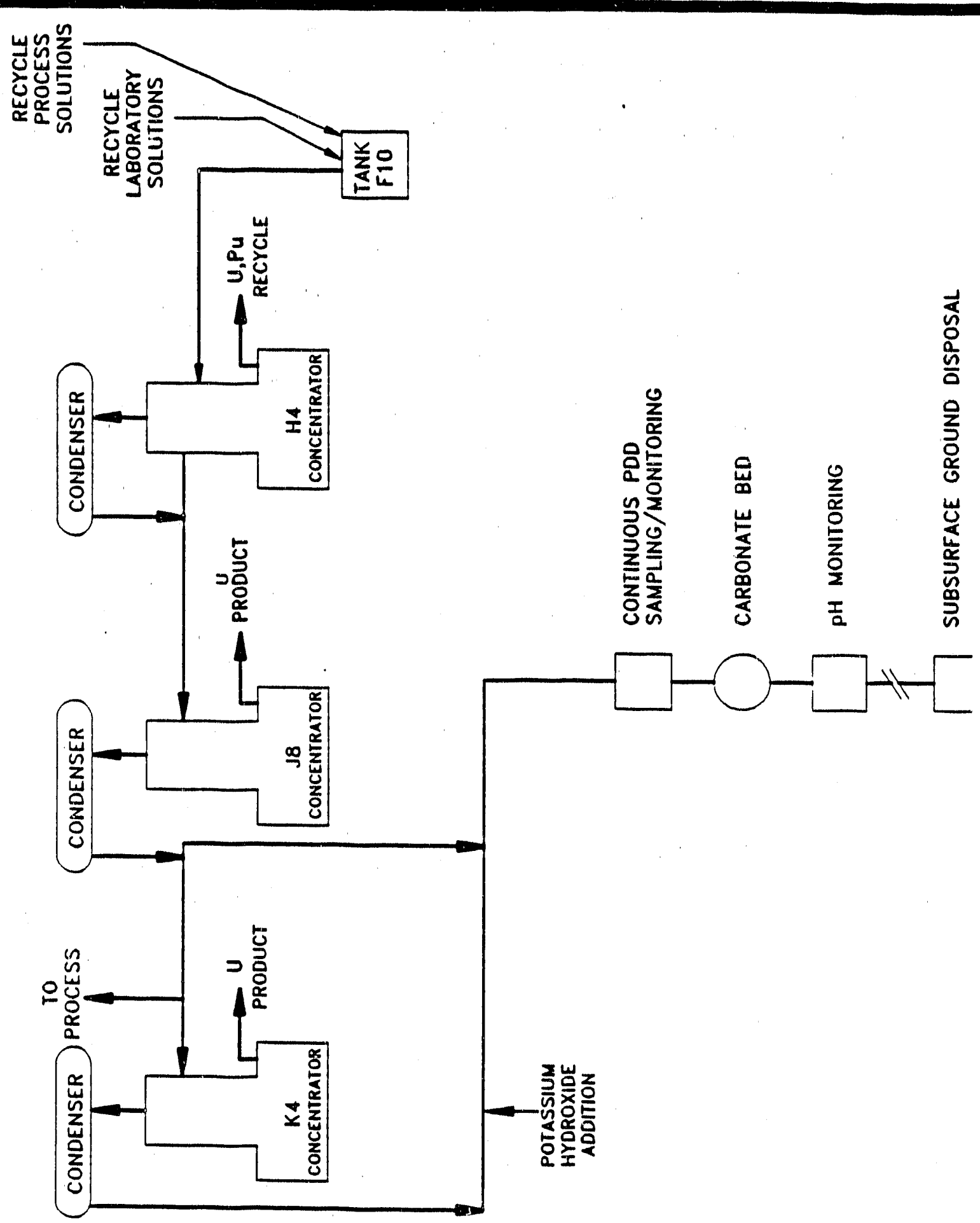

Figure 4-12. Historical Process Flow Diagram for PUREX Process Condensate F4-12 

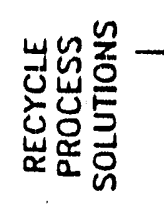

幽客员
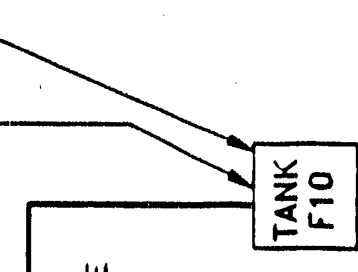

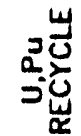

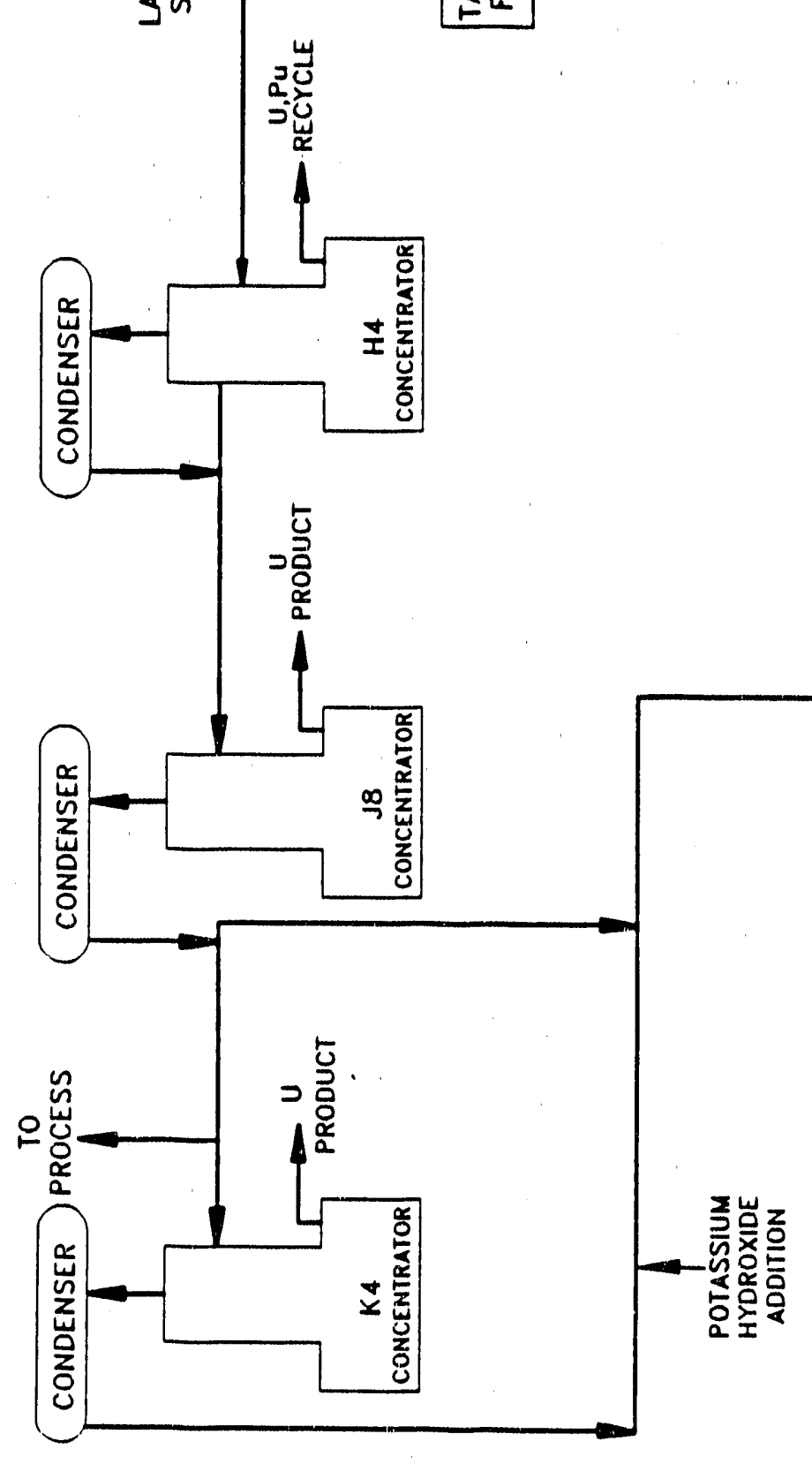

$\underset{\mathrm{H}}{\mathrm{I}}$

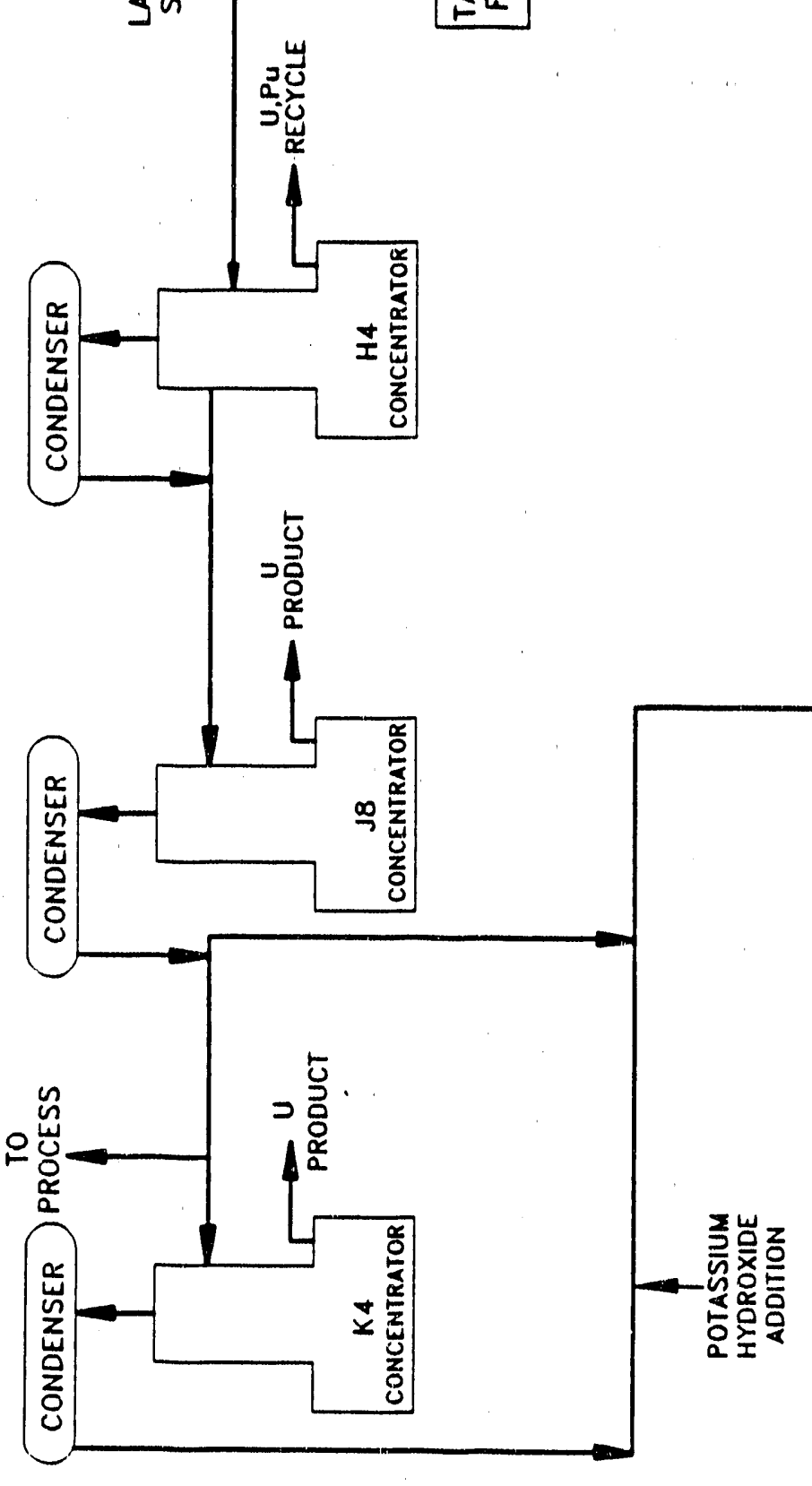

Figure 4-13. Interim Process Flow Diagram for PUREX Process Condensate F4-13 


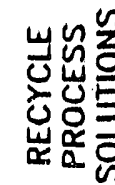

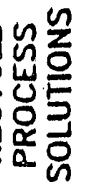
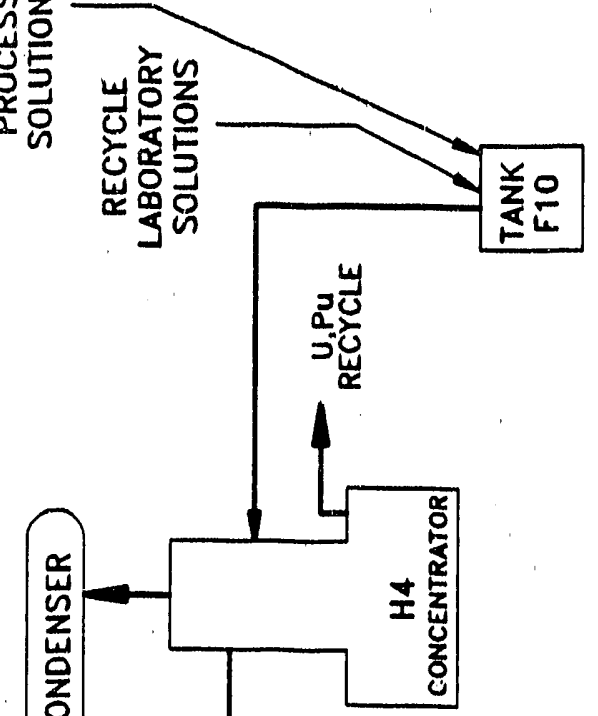

喽
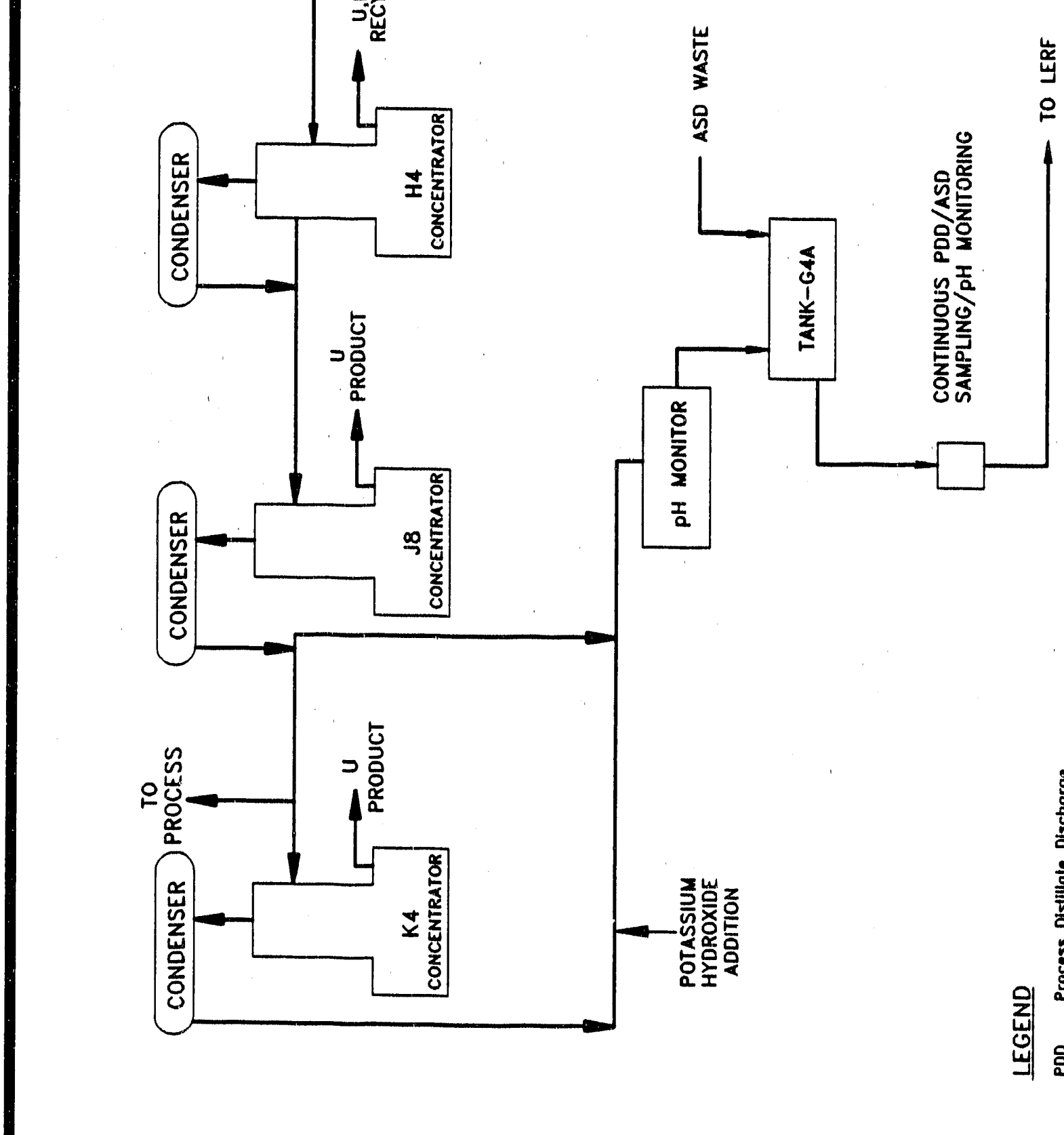

Figure 4-14. Process Flow Diagram for Future PUREX Process Condensate Generation F4-14 


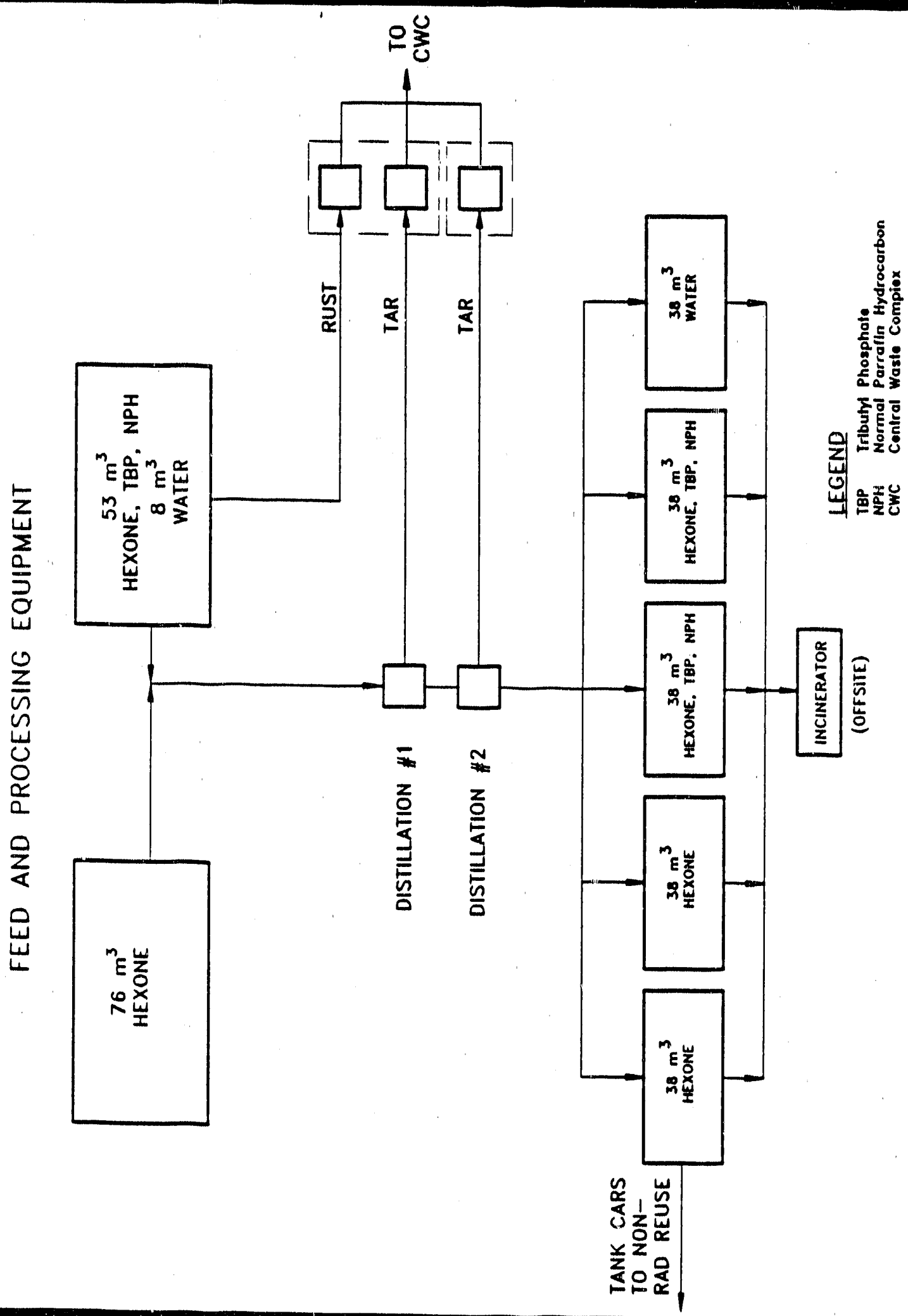


है

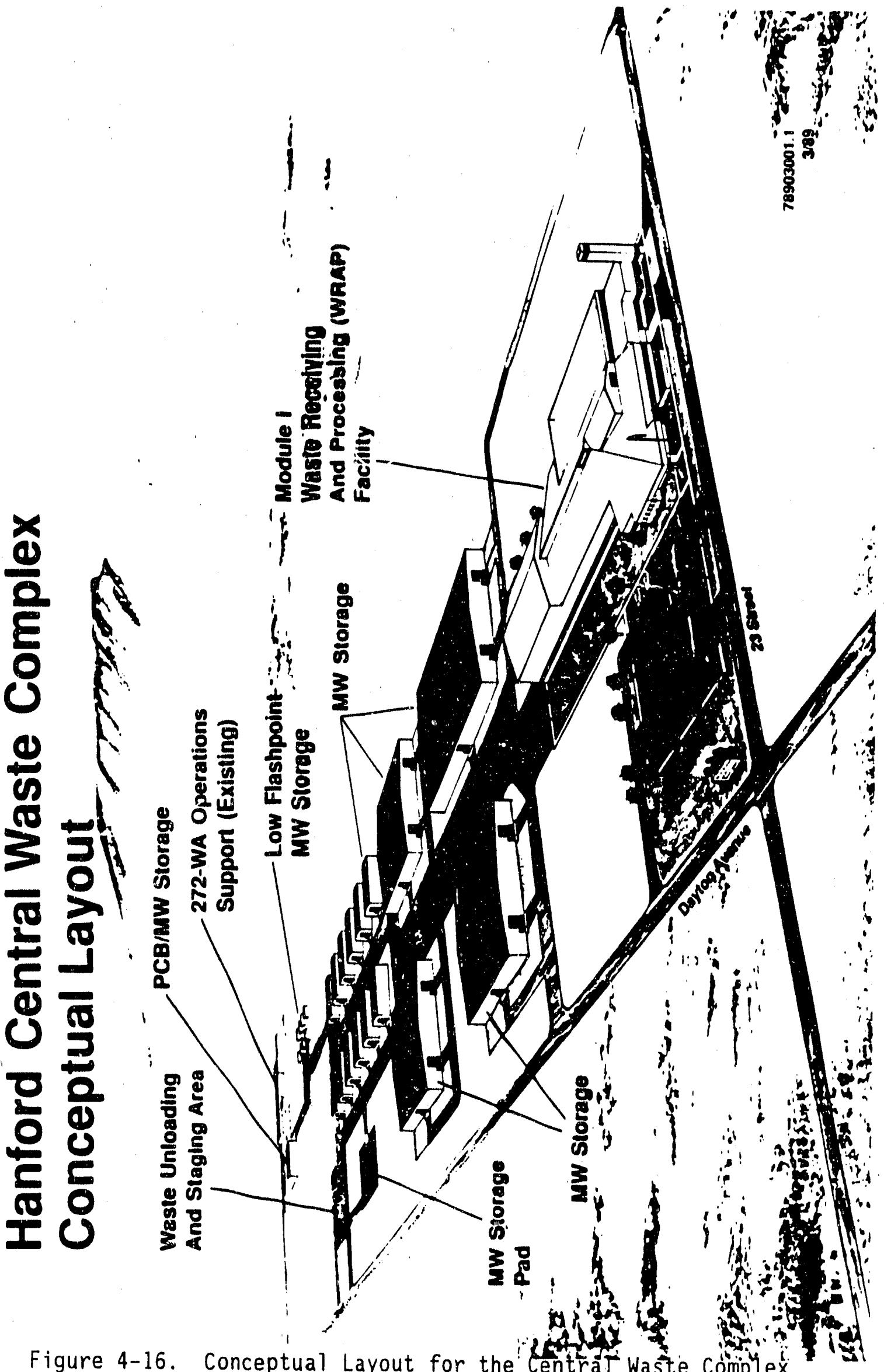



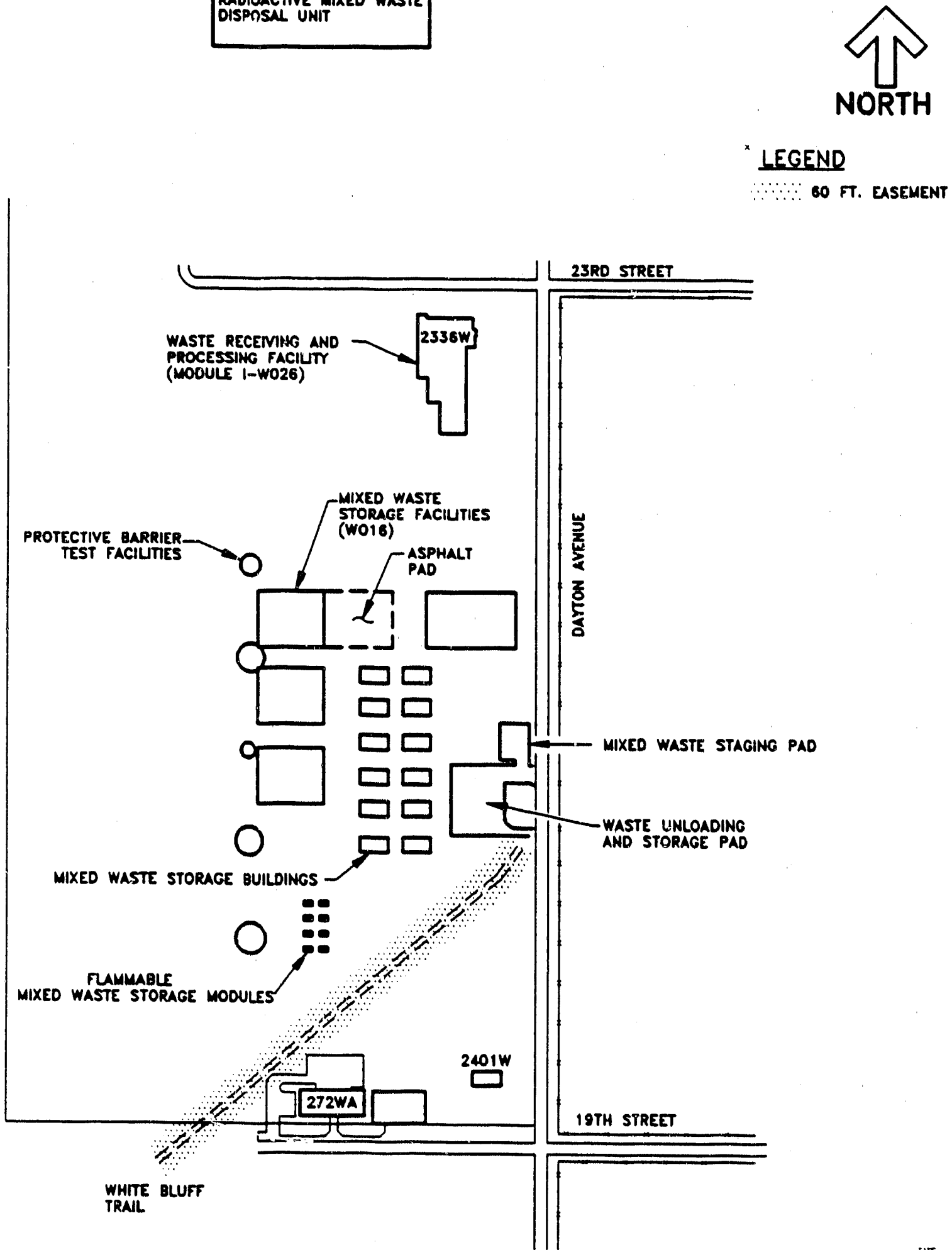

\section{23RO STREET}

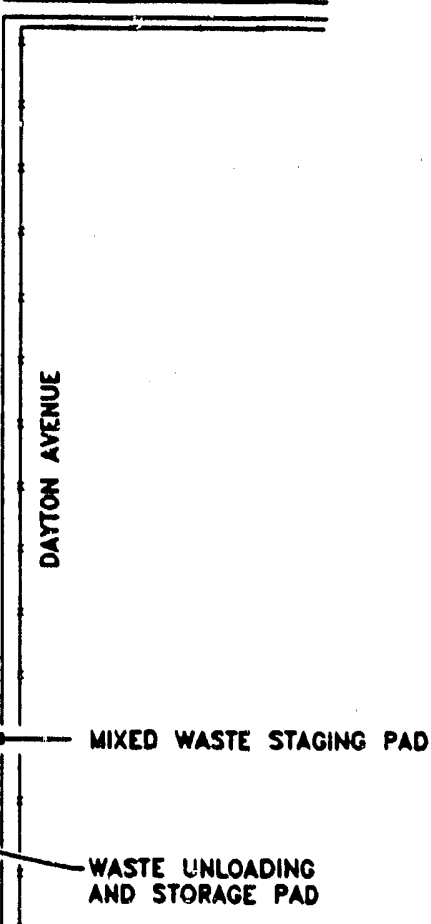

Figure 4-17. Plan View of Central Waste Complex 


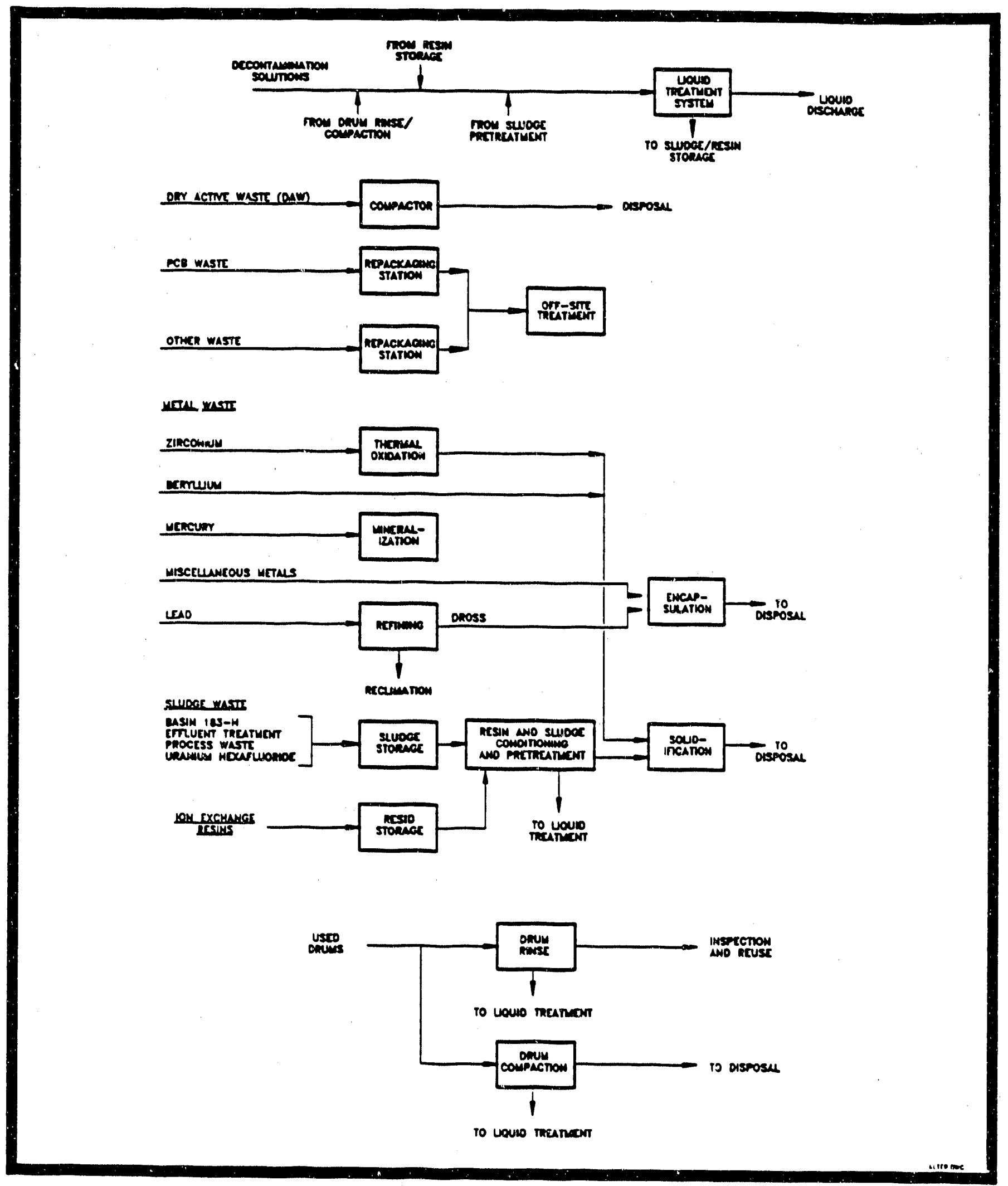

Figure 4-18. Process Flow Diagram for Proposed Waste Receiving and Processing Facility Module II 


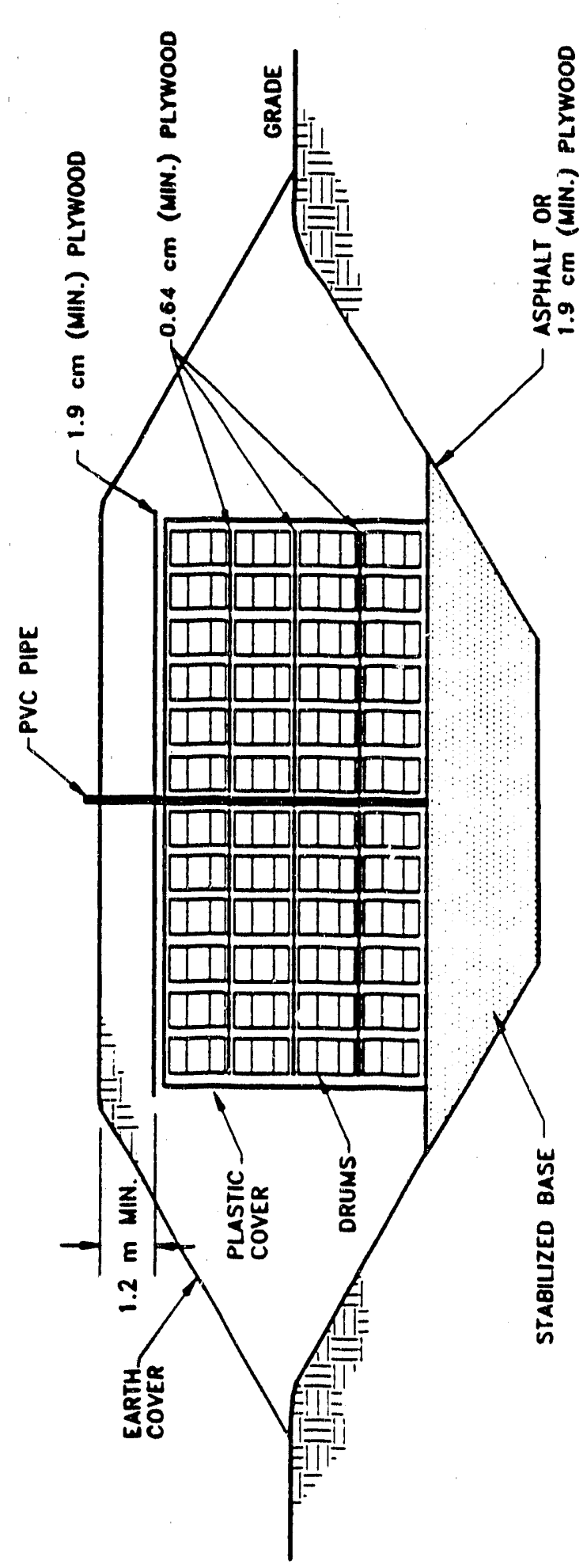

Figurf 4-19. Typical Configuration of a Retrievable Storage Unit for Contact-Handled Waste 


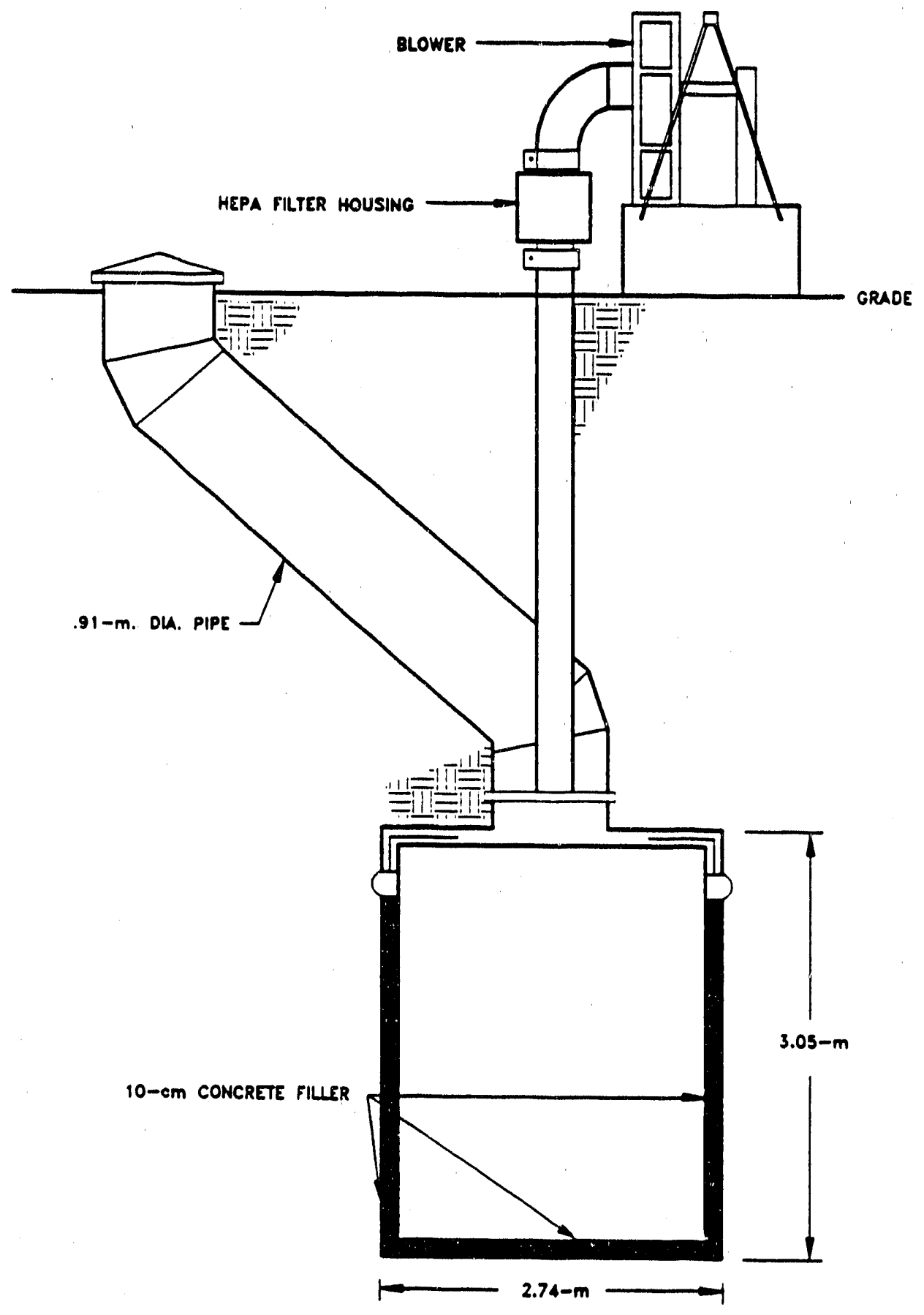

Figure 4-20. Typical Configuration of a Retrievable Storage Unit for Remote-Handled Waste 

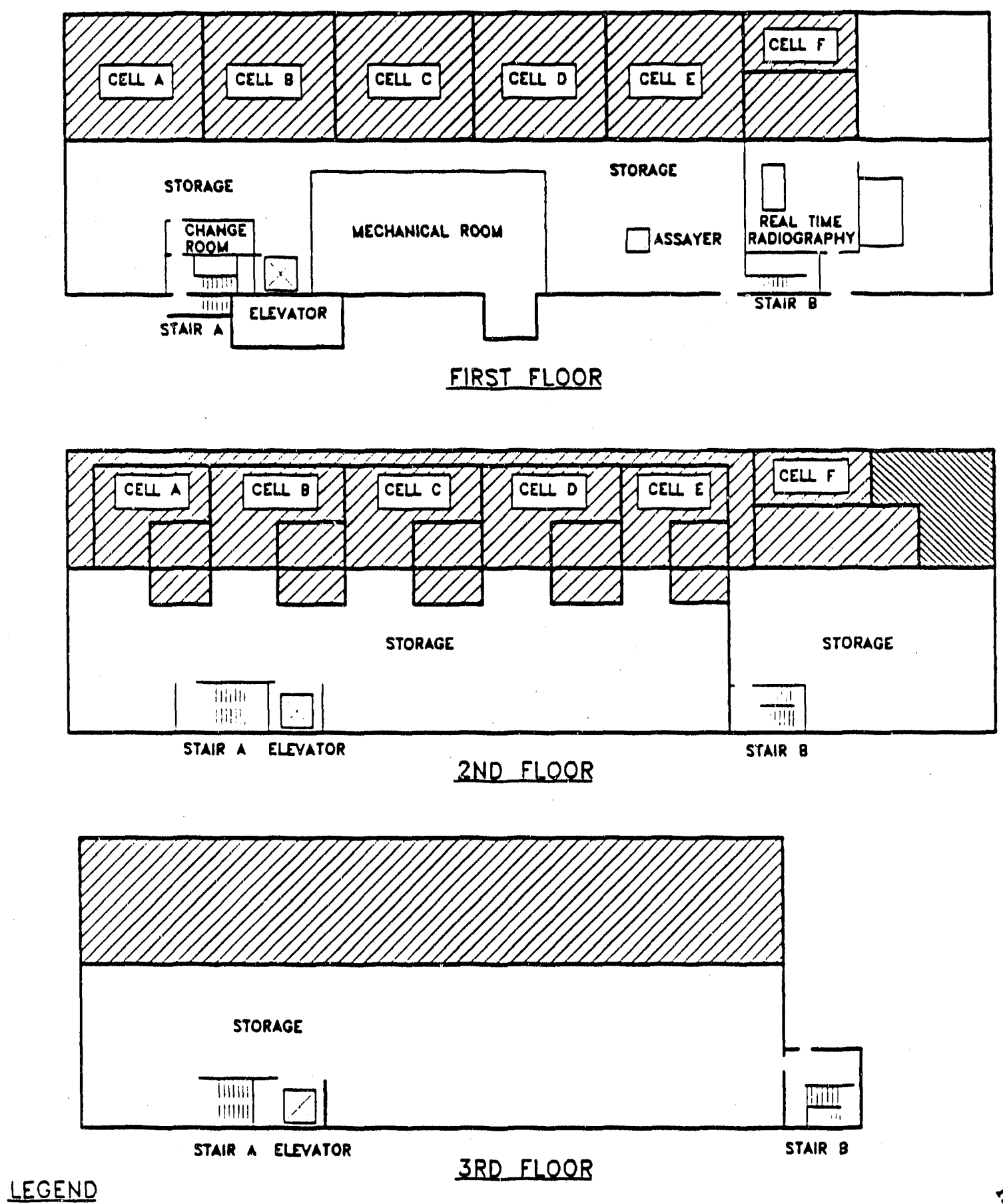

LEGEND

D77 SEALED PROCESS CANYON AREA

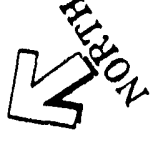

SEALED RAOLATION MEASUREMENT LABORATORY

Figure 4-21. Transuranic Storage and Assay Facility Floor Plan Fá $-2 \hat{i}$ 
Table 4-1. Projected Generation of Double-Shell Tank Waste. a (sheet 1 of 4 )

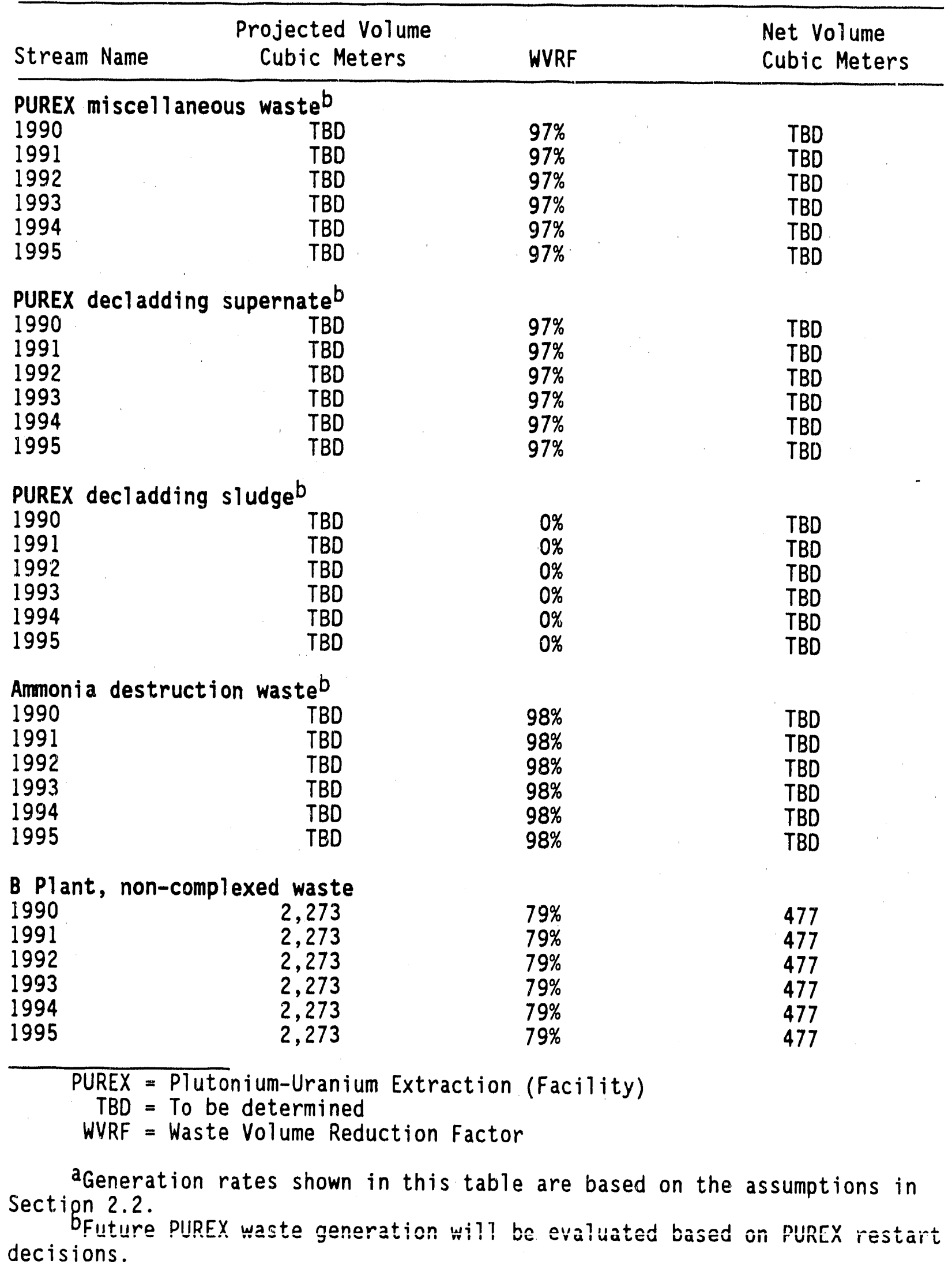


Table 4-1. Projected Generation of Double-She11 Tank Waste. ${ }^{2}$ (sheet 2 of 4 )

\begin{tabular}{|c|c|c|c|}
\hline Stream Name & $\begin{array}{c}\text { Projected Volume } \\
\text { Cubic Meters }\end{array}$ & WVRF & $\begin{array}{l}\text { Net Volume } \\
\text { Cubic Meters }\end{array}$ \\
\hline $\begin{array}{l}\text { B Plant, co } \\
1990 \\
1991 \\
1992 \\
1993 \\
1994 \\
1995\end{array}$ & $\begin{array}{r}\text { :omplexed waste } \\
15 \\
15 \\
15 \\
15 \\
15 \\
15\end{array}$ & $\begin{array}{l}14 \% \\
14 \% \\
14 \% \\
14 \% \\
14 \% \\
14 \%\end{array}$ & $\begin{array}{l}1 \\
13 \\
13 \\
13 \\
13 \\
13 \\
13\end{array}$ \\
\hline $\begin{array}{l}\text { B Plant cel } \\
1990 \\
1991 \\
1992 \\
1993 \\
1994 \\
1995\end{array}$ & 11 cleanout & $\begin{array}{l}79 \% \\
79 \% \\
79 \% \\
79 \% \\
79 \% \\
79 \%\end{array}$ & $\begin{array}{r}95 \\
38 \\
10 \\
0 \\
0 \\
0\end{array}$ \\
\hline $\begin{array}{l}\text { Plutonium R } \\
1990 \\
1991 \\
1992 \\
1993 \\
1994 \\
1995\end{array}$ & $\begin{array}{c}\text { Reclamation Facility: m } \\
620 \\
1,100 \\
993 \\
993 \\
993 \\
993\end{array}$ & $\begin{array}{l}\text { niscellaneous waste }(19.5 \% \\
60 \% \\
60 \% \\
60 \% \\
60 \% \\
60 \% \\
60 \%\end{array}$ & $\begin{array}{c}\text { sol ids ) } \\
248 \\
440 \\
397 \\
397 \\
397 \\
397\end{array}$ \\
\hline $\begin{array}{l}\text { Remote mech } \\
1990 \\
1991 \\
1992 \\
1993 \\
1994 \\
1995\end{array}$ & $\begin{array}{c}\text { hanical C-line waste }(4.2 \\
0 \\
127 \\
153 \\
153 \\
153 \\
153\end{array}$ & $\begin{array}{r}7 \% \text { solids) } \\
72 \% \\
72 \% \\
72 \% \\
72 \% \\
72 \% \\
72 \%\end{array}$ & $\begin{array}{r}0 \\
36 \\
43 \\
43 \\
43 \\
43\end{array}$ \\
\hline $\begin{array}{l}\text { Plutonium F } \\
1990 \\
1991 \\
1992 \\
1993 \\
1994 \\
1995\end{array}$ & $\begin{array}{r}\text { Finishing Plant: laborat } \\
51 \\
51 \\
51 \\
51 \\
51 \\
51\end{array}$ & $\begin{array}{l}\text { tory waste (4.5\% solids) } \\
60 \% \\
60 \% \\
60 \% \\
60 \% \\
60 \% \\
60 \%\end{array}$ & $\begin{array}{l}20 \\
20 \\
20 \\
20 \\
20 \\
20\end{array}$ \\
\hline
\end{tabular}

WVRF = Waste Volume Reduction Factor

a Generation rates shown in this table are based on the assumptions in Section 2.2. 
Table 4-1. Projected Generation of Double-Shell Tank Waste. ${ }^{a}$ (sheet 3 of 4 )

\begin{tabular}{|c|c|c|c|}
\hline Stream Name & $\begin{array}{l}\text { Projected Volume } \\
\text { Cubic Meters }\end{array}$ & WVRF & $\begin{array}{l}\text { Net Volume } \\
\text { Cubic Meters }\end{array}$ \\
\hline \multicolumn{2}{|c|}{$\begin{array}{lr}\text { S Plant miscellaneous waste } \\
1990 & 227 \\
1991 & 227 \\
1992 & 227 \\
1993 & 227 \\
1994 & 227 \\
1995 & 227\end{array}$} & $\begin{array}{l}98 \% \\
98 \% \\
98 \% \\
98 \% \\
98 \% \\
98 \%\end{array}$ & $\begin{array}{l}5 \\
5 \\
5 \\
5 \\
5 \\
5\end{array}$ \\
\hline \multicolumn{2}{|c|}{$\begin{array}{lr}\text { T Plant miscellaneous waste } \\
1990 & 189 \\
1991 & 189 \\
1992 & 189 \\
1993 & 189 \\
1994 & 189 \\
1995 & 189\end{array}$} & $\begin{array}{l}98 \% \\
98 \% \\
98 \% \\
98 \% \\
98 \% \\
98 \%\end{array}$ & $\begin{array}{l}4 \\
4 \\
4 \\
4 \\
4 \\
4\end{array}$ \\
\hline $\begin{array}{l}100 N \\
1990 \\
1991 \\
1992 \\
1993 \\
1994 \\
1995\end{array}$ & $\begin{array}{l}239 \\
239 \\
239 \\
239 \\
239 \\
239\end{array}$ & $\begin{array}{l}97 \% \\
97 \% \\
97 \% \\
97 \% \\
97 \% \\
97 \%\end{array}$ & $\begin{array}{l}7 \\
7 \\
7 \\
7 \\
7 \\
7\end{array}$ \\
\hline \multicolumn{2}{|c|}{$\begin{array}{ll}300 \text { Area 1ab waste } & \\
1990 & 227 \\
1991 & 227 \\
1992 & 227 \\
1993 & 227 \\
1994 & 227 \\
1995 & 227\end{array}$} & $\begin{array}{l}98 \% \\
98 \% \\
98 \% \\
98 \% \\
98 \% \\
98 \%\end{array}$ & $\begin{array}{l}5 \\
5 \\
5 \\
5 \\
5 \\
5\end{array}$ \\
\hline \multicolumn{2}{|c|}{$\begin{array}{lr}200 \text { East Area salt well waste } \\
1990 \\
1991 \\
1992 \\
1993 \\
1994 \\
1995 & 2564 \\
995 & 250 \\
0 & 0 \\
& 2,030\end{array}$} & $\begin{array}{l}35.5 \% \\
35.5 \% \\
35.5 \% \\
35.5 \% \\
35.5 \% \\
35.5 \%\end{array}$ & $\begin{array}{r}371 \\
1,654 \\
0 \\
161 \\
0 \\
1,310\end{array}$ \\
\hline
\end{tabular}


Table 4-1. Projected Generation of Double-Shell Tank Waste. ${ }^{a}$ (sheet 4 of 4 )

\begin{tabular}{|c|c|c|c|}
\hline Stream Name & $\begin{array}{l}\text { Projected Volume } \\
\text { Cubic Meters }\end{array}$ & WVRF & $\begin{array}{l}\text { Net Volume } \\
\text { Cubic Meters }\end{array}$ \\
\hline \multicolumn{2}{|c|}{$\begin{array}{lc}200 \text { West Area salt well waste } \\
1990 & 129 \\
1991 & 0 \\
1992 & 3,739 \\
1993 & 3,170 \\
1994 & 1,746 \\
1995 & 796\end{array}$} & $\begin{array}{l}35.5 \% \\
35.5 \% \\
35.5 \% \\
35.5 \% \\
35.5 \% \\
35.5 \%\end{array}$ & $\begin{array}{r}83 \\
0 \\
2,411 \\
2,045 \\
1,127 \\
513\end{array}$ \\
\hline $\begin{array}{l}\text { UO }{ }_{3} \text { Plant wa } \\
1990 \\
1991 \\
1992 \\
1993 \\
1994 \\
1995\end{array}$ & $\begin{array}{r}0 \\
303 \\
0 \\
481 \\
481 \\
481\end{array}$ & $\begin{array}{l}97 \% \\
97 \% \\
97 \% \\
97 \% \\
97 \% \\
97 \%\end{array}$ & $\begin{array}{r}0 \\
9 \\
0 \\
14 \\
14 \\
14\end{array}$ \\
\hline $\begin{array}{l}\text { Tank farm mi } \\
1990 \\
1991 \\
1992 \\
1993 \\
1994 \\
1995\end{array}$ & $\begin{array}{l}\text { aneous water addit } \\
\qquad \begin{array}{c}1,500 \\
1,500 \\
1,500 \\
1,500 \\
1,500 \\
1,500\end{array}\end{array}$ & $\begin{array}{l}98 \% \\
98 \% \\
98 \% \\
98 \% \\
98 \% \\
98 \%\end{array}$ & $\begin{array}{l}30 \\
30 \\
30 \\
30 \\
30 \\
30\end{array}$ \\
\hline $\begin{array}{l}\text { Evaporator } \\
1990\end{array}$ & $\begin{array}{l}\text { water } \\
1,515\end{array}$ & $98 \%$ & 30 \\
\hline
\end{tabular}

WVRF = Waste Volume Reduction Factor

aGeneration rates shown in this table are based on the assumptions in Section 2.2. 
Table 4-2. Chemical Concentrations in Double-Shell Tank Waste.

\begin{tabular}{|c|c|c|c|c|}
\hline Constituent & $N$ & $\begin{array}{c}\text { Average } \\
\text { (Moles/L) }\end{array}$ & $\begin{array}{l}\text { Minimum } \\
\text { (Moles } / L)\end{array}$ & $\begin{array}{l}\text { Maximum } \\
\text { (Moles/L) }\end{array}$ \\
\hline $\begin{array}{l}\text { Aluminum } \\
\text { Ammonium } \\
\text { Barium } \\
\text { Boron } \\
\text { Cadmium } \\
\text { Calcium } \\
\text { Carbonate } \\
\text { Chloride } \\
\text { Chromium } \\
\text { Copper } \\
\text { Fluoride } \\
\text { Hydroxide } \\
\text { Iron } \\
\text { Lanthanum } \\
\text { Lead } \\
\text { Magnesium } \\
\text { Manganese } \\
\text { Molybdenum } \\
\text { Mercury } \\
\text { Nickel } \\
\text { Nitrate } \\
\text { Nitrite } \\
\text { Phosphate } \\
\text { Phosphorus } \\
\text { Potassium } \\
\text { Silicon } \\
\text { Silver } \\
\text { Sodium } \\
\text { Sulfate } \\
\text { Zinc } \\
\text { Zirconium } \\
\text { Toc }\end{array}$ & $\begin{array}{r}91 \\
31 \\
12 \\
22 \\
9 \\
40 \\
86 \\
74 \\
33 \\
12 \\
56 \\
97 \\
21 \\
11 \\
3 \\
30 \\
15 \\
11 \\
1 \\
22 \\
99 \\
101 \\
77 \\
19 \\
68 \\
20 \\
1 \\
79 \\
48 \\
10 \\
16 \\
91\end{array}$ & $\begin{array}{l}7.8 \mathrm{E}-01 \\
9.7 \mathrm{E}-02 \\
1.4 \mathrm{E}-03 \\
1.9 \mathrm{E}-02 \\
4.1 \mathrm{E}-04 \\
5.2 \mathrm{E}-03 \\
2.4 \mathrm{E}-01 \\
1.2 \mathrm{E}-01 \\
1.9 \mathrm{E}-02 \\
2.2 \mathrm{E}-4 \\
1.0 \mathrm{E}+00 \\
1.7 \mathrm{E}+00 \\
7.0 \mathrm{E}-0 \\
2.8 \mathrm{E}-03 \\
5.7 \mathrm{E}-03 \\
4.3 \mathrm{E}-03 \\
5.9 \mathrm{E}-02 \\
8.8 \mathrm{E}-04 \\
1.5 \mathrm{E}-04 \\
2.5 \mathrm{E}-03 \\
1.5 \mathrm{E}+00 \\
9.9 \mathrm{E}-01 \\
5.8 \mathrm{E}-02 \\
9.6 \mathrm{E}-02 \\
2.0 \mathrm{E}-01 \\
8.0 \mathrm{E}-02 \\
1.8 \mathrm{E}-03 \\
5.7 \mathrm{E}+00 \\
5.0 \mathrm{E}-02 \\
5.1 \mathrm{E}-04 \\
5.7 \mathrm{E}-01 \\
1.3 \mathrm{E}+01\end{array}$ & $\begin{array}{l}1.8 \mathrm{E}-05 \\
5.0 \mathrm{E}-03 \\
1.8 \mathrm{E}-05 \\
5.8 \mathrm{E}-04 \\
5.9 \mathrm{E}-05 \\
1.9 \mathrm{E}-05 \\
1.0 \mathrm{E}-03 \\
2.6 \mathrm{E}-04 \\
4.7 \mathrm{E}-05 \\
8.2 \mathrm{E}-06 \\
2.5 \mathrm{E}-04 \\
4.6 \mathrm{E}-02 \\
1.0 \mathrm{E}-05 \\
2.1 \mathrm{E}-04 \\
6.0 \mathrm{E}-04 \\
1.6 \mathrm{E}-06 \\
5.7 \mathrm{E}-05 \\
1.1 \mathrm{E}-04 \\
--\overline{-}- \\
4.2 \mathrm{E}-04 \\
2.0 \mathrm{E}-03 \\
1.6 \mathrm{E}-05 \\
2.0 \mathrm{E}-07 \\
3.9 \mathrm{E}-03 \\
1.1 \mathrm{E}-04 \\
4.8 \mathrm{E}-04 \\
-1-0 \mathrm{E}-04 \\
4.0 \mathrm{E}-04 \\
1.5 \mathrm{E}-04 \\
2.1 \mathrm{E}-04 \\
3.4 \mathrm{E}-04 \\
1.5 \mathrm{E}-02\end{array}$ & $\begin{array}{l}2.9 E+00 \\
4.1 E-01 \\
5.0 E-03 \\
1.2 E-01 \\
1.4 E-03 \\
1.8 E-02 \\
1.1 E+00 \\
9.9 E-01 \\
3.2 E-01 \\
1.2 E-03 \\
1.1 E+01 \\
6.9 E+00 \\
3.3 E-02 \\
1.5 E-02 \\
1.5 E-02 \\
4.2 E-02 \\
8.3 E-01 \\
2.2 E-03 \\
---- \\
8.8 E-03 \\
4.1 E+00 \\
3.6 E+00 \\
3.9 E-01 \\
3.8 E-01 \\
6.9 E-01 \\
4.7 E-01 \\
-1.6- \\
1.6 E+01 \\
8.9 E-01 \\
1.2 E-03 \\
1.6 E+00 \\
8.9 E+01\end{array}$ \\
\hline
\end{tabular}

$N=$ number of samples in which analyte was found 
Table 4-3. PUREX Aging Waste Composition.

\begin{tabular}{cc}
\hline Constituent & $\begin{array}{c}\text { Concentration } \\
\text { (moles/liter) }\end{array}$ \\
\hline $\mathrm{Na}^{+}$ & 3.97 \\
$\mathrm{OH}^{-}$ & 0.77 \\
$\mathrm{AlO}_{2}^{-}$ & 0.55 \\
$\mathrm{NO}_{3}-\mathrm{NO}_{2}^{-}$ & 2.02 \\
$\mathrm{SO}_{4}^{-}$ & 0.13 \\
$\mathrm{~F}^{-}$ & 0.13 \\
$\mathrm{Fe}(\mathrm{OH})_{3}$ & 0.10 \\
$\mathrm{Cr}(\mathrm{OH})_{3}$ & 0.009 \\
$\mathrm{Ni}(\mathrm{OH})_{2}$ & 0.006 \\
Density & $1.17-1.20 \mathrm{~g} / \mathrm{cm}^{3}$ \\
\hline PUREX & Plutonium-Uranium Extraction \\
& (Facility)
\end{tabular}


Table 4-4. Sample Analysis for PUREX Aging Waste Stored in Tanks 241-AZ-101 and 241-AZ-102.

\begin{tabular}{|c|c|c|c|c|}
\hline Constituent & $N$ & $\begin{array}{l}\text { Average } \\
\text { (Moles/1) }\end{array}$ & $\begin{array}{l}\text { Minimum } \\
\text { (Moles/1) }\end{array}$ & $\begin{array}{l}\text { Maximum } \\
\text { (Moles } / 1 \text { ) }\end{array}$ \\
\hline $\begin{array}{l}\text { Aluminum } \\
\text { Barium } \\
\text { Boron } \\
\text { Cadmium } \\
\text { Calcium } \\
\text { Carbonate } \\
\text { Chloride } \\
\text { Chromium } \\
\text { Copper } \\
\text { Fluoride } \\
\text { Hydroxide } \\
\text { Iron } \\
\text { Lanthanum } \\
\text { Lead } \\
\text { Magnesium } \\
\text { Molybdenum } \\
\text { Nickel } \\
\text { Nitrate } \\
\text { Nitrite } \\
\text { Phosphate } \\
\text { Phosphorus } \\
\text { Potassium } \\
\text { Silicon } \\
\text { Silver. } \\
\text { Sodium } \\
\text { Sulfate } \\
\text { Zinc } \\
\text { Zirconium } \\
\text { ToC }\end{array}$ & $\begin{array}{r}18 \\
2 \\
2 \\
2 \\
9 \\
10 \\
4 \\
12 \\
4 \\
8 \\
12 \\
4 \\
1 \\
2 \\
6 \\
3 \\
5 \\
14 \\
13 \\
11 \\
7 \\
6 \\
4 \\
1 \\
16 \\
9 \\
2 \\
2 \\
16\end{array}$ & $\begin{array}{l}2.2 \mathrm{E}-01 \\
1.4 \mathrm{E}-03 \\
5.9 \mathrm{E}-04 \\
2.9 \mathrm{E}-04 \\
3.2 \mathrm{E}-02 \\
1.6 \mathrm{E}-01 \\
2.7 \mathrm{E}-02 \\
6.3 \mathrm{E}-03 \\
1.7 \mathrm{E}-04 \\
1.6 \mathrm{E}+00 \\
5.1 \mathrm{E}-01 \\
2.4 \mathrm{E}-01 \\
1.4 \mathrm{E}-02 \\
3.7 \mathrm{E}-03 \\
4.5 \mathrm{E}-02 \\
3.4 \mathrm{E}-03 \\
1.7 \mathrm{E}-02 \\
7.1 \mathrm{E}-01 \\
3.3 \mathrm{E}-01 \\
1.4 \mathrm{E}-\mathrm{C1} \\
2.0 \mathrm{E}-01 \\
5.4 \mathrm{E}-02 \\
1.3 \mathrm{E}-02 \\
1.7 \mathrm{E}-04 \\
3.4 \mathrm{E}+00 \\
9.3 \mathrm{E}-02 \\
8.5 \mathrm{E}-04 \\
1.9 \mathrm{E}-01 \\
1.3 \mathrm{E}+01\end{array}$ & $\begin{array}{l}2.0 \mathrm{E}-05 \\
4.0 \mathrm{E}-10 \\
7.1 \mathrm{E}-06 \\
9.0 \mathrm{E}-09 \\
3.2 \mathrm{E}-07 \\
6.7 \mathrm{E}-04 \\
7.0 \mathrm{E}-03 \\
2.6 \mathrm{E}-07 \\
4.4 \mathrm{E}-05 \\
4.6 \mathrm{E}-03 \\
7.1 \mathrm{E}-03 \\
2.4 \mathrm{E}-07 \\
-\overline{-}- \\
4.0 \mathrm{E}-04 \\
6.9 \mathrm{E}-08 \\
9.0 \mathrm{E}-04 \\
2.1 \mathrm{E}-08 \\
2.5 \mathrm{E}-02 \\
3.5 \mathrm{E}-03 \\
3.1 \mathrm{E}-04 \\
6.4 \mathrm{E}-07 \\
3.8 \mathrm{E}-06 \\
1.7 \mathrm{E}-05 \\
-\overline{-}- \\
2.6 \mathrm{E}-04 \\
6.9 \mathrm{E}-03 \\
7.0 \mathrm{E}-09 \\
7.5 \mathrm{E}-08 \\
5.2 \mathrm{E}-02\end{array}$ & $\begin{array}{l}4.8 \mathrm{E}-01 \\
2.8 \mathrm{E}-03 \\
1.2 \mathrm{E}-03 \\
5.7 \mathrm{E}-04 \\
2.5 \mathrm{E}-01 \\
2.7 \mathrm{E}-01 \\
6.1 \mathrm{E}-02 \\
1.3 \mathrm{E}-02 \\
3.5 \mathrm{E}-04 \\
1.3 \mathrm{E}+01 \\
1.1 \mathrm{E}+00 \\
6.2 \mathrm{E}-01 \\
-\overline{-}- \\
7.0 \mathrm{E}-03 \\
2.0 \mathrm{E}-01 \\
1.6 \mathrm{E}-03 \\
8.0 \mathrm{E}-02 \\
1.8 \mathrm{E}+00 \\
7.9 \mathrm{E}-01 \\
8.7 \mathrm{E}-01 \\
8.2 \mathrm{E}-01 \\
1.2 \mathrm{E}-01 \\
5.0 \mathrm{E}-02 \\
-. .- \\
8.5 \mathrm{E}+00 \\
1.6 \mathrm{E}-01 \\
1.7 \mathrm{E}-03 \\
3.7 \mathrm{E}-01 \\
1.0 \mathrm{E}+02\end{array}$ \\
\hline
\end{tabular}

PUREX = Plutonium-Uranium Extraction (Facility) 
Table 4-5 Estimated Mass of Nonradioactive Chemical Components of Existing Single-Shell Tank Waste after Completion of Jet Pumping. (RHO 1985)

\begin{tabular}{|c|c|c|c|}
\hline Chemical & $\begin{array}{l}\text { Total bulk } \\
\text { sludge }(t)\end{array}$ & $\begin{array}{l}\text { Total bulk } \\
\text { salt cake ( } t)\end{array}$ & $\begin{array}{l}\text { Interstitial } \\
\text { liquid }(t)\end{array}$ \\
\hline \multicolumn{4}{|l|}{ Inert chemicals } \\
\hline $\mathrm{NaNO}_{3}$ & 20,000 & 110,000 & 2,500 \\
\hline $\mathrm{NaNO}_{2}$ & 3,000 & 2,300 & 1,900 \\
\hline $\mathrm{Na}_{2} \mathrm{CO}_{3}$ & 1,700 & 730 & 70 \\
\hline $\mathrm{NaOH}$ & 4,200 & 2,000 & 740 \\
\hline $\mathrm{NaAlO}_{2}$ & 950 & 1,900 & 1,500 \\
\hline $\mathrm{Na}_{3} \mathrm{PO}_{4}$ & 12,500 & 2,100 & 280 \\
\hline Cancrinite ${ }^{a}$ & 2,700 & --- & -- \\
\hline $\mathrm{A} 1(\mathrm{OH})_{3}$ & 2,300 & -- & -- \\
\hline $\mathrm{Ce}(\mathrm{OH})_{3}$ & 320 & -- & -- \\
\hline $\mathrm{Cr}(\mathrm{OH})_{3}$ & 190 & --- & -- \\
\hline $\mathrm{Cd}(\mathrm{OH})_{2}$ & 5 & -- & -- \\
\hline $\mathrm{Fe}(\mathrm{OH})_{3}$ & 1,200 & -- & -- \\
\hline $\mathrm{Sr}(\mathrm{OH})_{2}$ & 50 & -- & -- \\
\hline $\mathrm{BiPO}_{4}$ & 380 & -- & -- \\
\hline $\mathrm{CaCO}_{3}$ & 320 & $-\cdots$ & --- \\
\hline$F^{-}$ & 800 & -- & -- \\
\hline $\mathrm{Cl}^{-}$ & 40 & -- & -- \\
\hline $\mathrm{Hg}^{+}$ & 0.9 & -- & $\cdots-$ \\
\hline $\mathrm{MnO}_{2}$ & 190 & -- & -- \\
\hline $\mathrm{Ni}_{2} \mathrm{Fe}(\mathrm{CN})_{6}$ & 500 & -- & --- \\
\hline $\mathrm{P}_{2} \mathrm{O}_{5} \cdot 2 \mathrm{H}_{2} \mathrm{O} \cdot 44 \mathrm{H}_{2} \mathrm{O}$ & 20 & -- & -- \\
\hline $\mathrm{ZrO}_{2} \cdot 2 \mathrm{H}_{2} \mathrm{O}$ & 430 & -- & -- \\
\hline Organic Carbon & -- & $-\cdots$ & 200 \\
\hline $\mathrm{H}_{2} \mathrm{O}$ & 26,000 & 14,000 & 4,800 \\
\hline Totals & 77,796 & 133,030 & 11,990 \\
\hline
\end{tabular}

$(t)=$ metric tonnes

aknown silica additions are assumed to have reacted with aluminates and hydroxides to form cancrinite (assumed to be $\left.2 \mathrm{NaAlSiO}_{4} \cdot 0.52 \mathrm{NaNO}_{3} \cdot 0.68 \mathrm{H}_{2} \mathrm{O}\right)$. 
Table 4-6. Hanford Site Single-She11 Tank Releases. a (sheet 1 of 3 )

\begin{tabular}{crc}
\hline Tank & Volume (cubic meters) & Leak Reported \\
\hline $241-A-103$ & 20.8 & 1987 \\
$241-A-104$ & 9.5 & 1975 \\
$241-A-105$ & 18.9 & 1963 \\
$241-A X-102$ & 11.4 & 1988 \\
$241-B-107$ & 30.3 & 1980 \\
$241-B-110$ & 37.9 & 1981 \\
$241-B-201$ & 4.5 & 1980 \\
$241-B-203$ & 1.1 & 1983 \\
$241-B X-102$ & 265.2 & 1971 \\
$241-B X-108$ & 9.5 & 1974 \\
$241-B Y-103$ & 18.9 & 1973 \\
$241-B Y-108$ & 18.9 & 1972 \\
$241-C-101$ & 75.8 & 1980 \\
$241-C-2012$ & 2.1 & 1988 \\
$241-C-202$ & 1.7 & 1988 \\
$241-C-203$ & 1.5 & 1984 \\
$241-C-204$ & 1.3 & 1988 \\
$241-S X-104$ & 22.7 & 1988 \\
$241-S X-107$ & 18.9 & 1964 \\
$241-S X-108$ & 9.1 & 1962 \\
$241-S X-109$ & 18.9 & 1965 \\
$241-S X-110$ & 20.8 & 1976 \\
$241-S X-111$ & 7.6 & 1974 \\
$241-S X-112$ & 113.6 & 1969 \\
$241-S X-113$ & 56.8 & 1962 \\
\hline
\end{tabular}

aAfter some tanks vere declared to be leaking, cooling water may have been added to aid evaporative cooling. It is believed some of this water did not evaporate and therefore went into the ground. The past practice was to exclude the cooling water from the leak volume estimate. The volumes provided and date of initial release are the subject of continued evaluation and refinement and may be revised for improved accuracy as a result of these evaluations. 
Table 4-6. Hanford Site Single-Shell Tank Releases. a (sheet 2 of 3 )

\begin{tabular}{crc}
\hline Tank & Volume (cubic meters) & Leak Reported \\
\hline $241-S X-115$ & 189.4 & 1965 \\
$241-T-106$ & 435.6 & 1973 \\
$241-T-108$ & $<3.8$ & 1974 \\
$241-T-111$ & $<3.8$ & 1984 \\
$241-$ TY-107 & 9.5 & 1984 \\
$241-T Y-101$ & $<3.8$ & 1973 \\
$241-T Y-103$ & 11.4 & 1973 \\
$241-T Y-104$ & 5.3 & 1981 \\
$241-T Y-105$ & 132.6 & 1960 \\
$241-$ TY-106 & 75.8 & 1959 \\
$241-U-101$ & 113.6 & 1959 \\
$241-U-104$ & 208.3 & 1961 \\
$241-U-110$ & 30.7 & 1975 \\
$241-U-112$ & 32.2 & 1980 \\
$241-B-204$ & 1.5 & 1984 \\
$241-B Y-107$ & 57.2 & 1984 \\
$241-C-111$ & 20.8 & 1968 \\
$241-S-104$ & 90.9 & 1968 \\
$241-T-103$ & $<3.8$ & 1974 \\
$241-T-109$ & $<3.8$ & 1974 \\
$241-B-112$ & 7.6 & 1978 \\
$241-C-110$ & 7.6 & 1984 \\
\hline
\end{tabular}

aAfter some tanks were declared to be leaking, cooling water may have been added to aid evaporative cooling. It is believed some of this water did not evaporate and therefore went into the ground. The past practice was to exclude the cooling water from the leak volume estimate. The volumes provided and date of initial release are the subject of continued evaluation and refinement and may be revised for improved accuracy as a result of these evaluations. 
Table 4-6. Hanford Site Single-Sherl Tank Releases. ${ }^{\mathrm{a}}$ (sheet 3 of 3 )

Individual release volumes for the following tanks have not been determined. The total volume release from the following tanks is estimated to be $568.2 \mathrm{~m}^{3}$ (rounded to nearest $37.9 \mathrm{~m}^{3}$ ).

\begin{tabular}{rc}
\hline TANK & LEAK REPORTED \\
\hline $241-A X-104$ & 1977 \\
$241-B-101$ & 1974 \\
$241-B-103$ & 1978 \\
$241-B-105$ & 1978 \\
$241-B-111$ & 1978 \\
$241-B X-101$ & 1972 \\
$241-B X-110$ & 1976 \\
$241-B X-111$ & 1984 \\
$241-B Y-105$ & 1984 \\
$241-B Y-106$ & 1984 \\
$241-S X-114$ & 1972 \\
$241-T-107$ & 1984 \\
$241-T X-105$ & 1977 \\
$241-T X-110$ & 1977 \\
$241-T X-113$ & 1974 \\
$241-T X-114$ & 1974 \\
$241-T X-115$ & 1977 \\
$241-T X-116$ & 1977 \\
$241-T X-117$ & 1977 \\
\hline
\end{tabular}

affer some tanks were declared to be leaking, cooling water may have been added to aid evaporative cooling. It is believed some of this water did not evaporate and therefore went into the ground. The past practice was to exclude the cooling water from the leak volume estimate. The volumes provided and date of initial release are the subject of continued evaluation and refinement and may be revised for improved accuracy as a result of these evaluations. 
Table 4-7. Analytes Detected in 242-A Evaporator Process Condensate. (sheet 1 of 2)

\begin{tabular}{|c|c|c|}
\hline Analyte & $\begin{array}{l}\text { Number of Samples } \\
\text { Containing Analyte }\end{array}$ & $\begin{array}{l}\text { Average Concentration } \\
\text { (parts per billion) }\end{array}$ \\
\hline Total organic carbon & 31 & $2.6 E+04$ \\
\hline $\begin{array}{l}\text { INORGANIC CATIONS } \\
\text { Aluminum } \\
\text { Ammonium } \\
\text { Barium } \\
\text { Boron } \\
\text { Cadmium } \\
\text { Calcium } \\
\text { Copper } \\
\text { Iron } \\
\text { Magnesium } \\
\text { Manganese } \\
\text { Marcury } \\
\text { Nickel } \\
\text { Potassium } \\
\text { Silicon } \\
\text { Sodium } \\
\text { Vanadium } \\
\text { Zinc }\end{array}$ & $\begin{array}{r}29 \\
31 \\
4 \\
1 \\
1 \\
31 \\
5 \\
9 \\
14 \\
1 \\
24 \\
5 \\
30 \\
4 \\
25 \\
4 \\
15\end{array}$ & $\begin{array}{ll}8.4 & E+02 \\
4.1 & E+05 \\
6.8 & E+00 \\
1.3 & E+01 \\
5.0 & E+00 \\
2.7 & E+03 \\
2.6 & E+01 \\
6.3 & E+01 \\
5.0 & E+02 \\
5.0 & E+00 \\
3.0 & E-01 \\
1.4 & E+01 \\
2.6 & E+03 \\
6.8 & E+03 \\
3.3 & E+03 \\
6.3 & E+00 \\
1.3 & E+01\end{array}$ \\
\hline $\begin{array}{l}\text { INORGANIC ANIONS } \\
\text { Chloride } \\
\text { Fluoride (ion chromatograin) } \\
\text { Fluoride (ion-specific electrode) } \\
\text { Nitrate } \\
\text { Sulfate } \\
\text { Sulfide }\end{array}$ & $\begin{array}{r}7 \\
1 \\
7 \\
4 \\
17 \\
2\end{array}$ & $\begin{array}{ll}1.0 & E+03 \\
2.1 & E+03 \\
4.0 & E+01 \\
2.8 & E+03 \\
2.6 & E+03 \\
3.6 & E+04\end{array}$ \\
\hline $\begin{array}{l}\text { ACIDS } \\
\text { Caproic acid }\end{array}$ & 1 & $7.0 E+01$ \\
\hline $\begin{array}{l}\text { PARAF INS } \\
\text { 2-Methylnonane } \\
\text { Dodecane } \\
\text { Heptadecane } \\
\text { Hexadecane } \\
\text { Pentadecane } \\
\text { Tetradecane } \\
\text { Tridecane }\end{array}$ & $\begin{array}{r}2 \\
2 \\
1 \\
1 \\
1 \\
23 \\
23\end{array}$ & $\begin{array}{l}1.6 E+01 \\
4.3 E+01 \\
1.8 E+01 \\
1 .-E+01 \\
2.0 E+01 \\
7.6 E+01 \\
7.0 E+01\end{array}$ \\
\hline
\end{tabular}


Table 4-7. Analytes Detected in 242-A Evaporator Process Condensate. (sheet 2 of 2)

\begin{tabular}{|c|c|c|}
\hline Analyte & $\begin{array}{l}\text { Number of Samples } \\
\text { Containing Analyte }\end{array}$ & $\begin{array}{l}\text { Average Concentration } \\
\text { (parts per billion) }\end{array}$ \\
\hline ALCOHOLS & & \\
\hline $\begin{array}{l}\text { 2-Propanol } \\
\text { Butyl alcohol } \\
\text { Ethyl alcohol }\end{array}$ & $\begin{array}{r}10 \\
30 \\
1\end{array}$ & $\begin{array}{ll}2.2 & E+01 \\
9.8 & E+03 \\
2.0 & E+00\end{array}$ \\
\hline $\begin{array}{l}\text { ALDEHYDES } \\
\text { Butylaldehyde }\end{array}$ & 14 & $5.6 E+01$ \\
\hline $\begin{array}{l}\text { KETONES } \\
\text { Acetone } \\
\text { Methyl ethy1 ketone } \\
\text { Methyl n-butyl ketone } \\
\text { Methyl n-propyl ketone } \\
\text { Hexone }\end{array}$ & $\begin{array}{r}36 \\
25 \\
16 \\
8 \\
10\end{array}$ & $\begin{array}{ll}9.8 & E+02 \\
5.1 & E+01 \\
1.3 & E+01 \\
9.3 & E+00 \\
1.1 & E+01\end{array}$ \\
\hline $\begin{array}{l}\text { CYCLICS } \\
\text { Benzaldehyde } \\
\text { Benzyl al cohol } \\
\text { Phenol } \\
\text { Tetrahydrofuran }\end{array}$ & $\begin{array}{r}1 \\
9 \\
1 \\
24\end{array}$ & $\begin{array}{ll}2.3 & E+01 \\
1.3 & E+01 \\
3.3 & E+01 \\
3.7 & E+01\end{array}$ \\
\hline $\begin{array}{l}\text { ESTERS } \\
\text { Tributyl phosphate }\end{array}$ & 31 & $3.9 E+03$ \\
\hline $\begin{array}{l}\text { NITROGEN-CONTAINING ORGANICS } \\
3,5 \text {-Dimethylpridine } \\
\text { Dimethylnitrosamine } \\
\text { Pyridine }\end{array}$ & $\begin{array}{l}3 \\
1 \\
1\end{array}$ & $\begin{array}{ll}2.1 & E+01 \\
5.7 & E+01 \\
5.5 & E+02\end{array}$ \\
\hline $\begin{array}{l}\text { ETHERS AND GLYCOLS } \\
\text { 2-Butoxyethanol } \\
\text { Butoxydiglycol } \\
\text { Butoxyglycol } \\
\text { Butoxytriethylene glycol } \\
\text { Ethoxytriethylene glycol } \\
\text { Methoxydiglycol } \\
\text { Methoxytriglycol } \\
\text { Triglyme }\end{array}$ & $\begin{array}{r}25 \\
2 \\
21 \\
1 \\
4 \\
2 \\
2 \\
1\end{array}$ & $\begin{array}{ll}3.8 & E+02 \\
1.9 & E+01 \\
2.8 & E+02 \\
3.5 & E+01 \\
9.9 & E+01 \\
4.0 & E+01 \\
2.2 & E+02 \\
9.0 & E+01\end{array}$ \\
\hline $\begin{array}{l}\text { RADIONUCLIDES } \\
\text { Strontium } \\
\text { Uranium }\end{array}$ & $\begin{array}{r}4 \\
21\end{array}$ & $\begin{array}{ll}1.6 & E+01 \\
4.4 & E-01\end{array}$ \\
\hline
\end{tabular}


Table 4-8. Analytes Reported in PUREX Ammonia Scrubber Discharge.

\begin{tabular}{|c|c|c|}
\hline Constituent & $\mathrm{Na}^{\mathrm{a}}$ & $\begin{array}{c}\text { Average } \\
\text { concentration } b\end{array}$ \\
\hline $\begin{array}{l}\text { Calcium } \\
\text { Chloride } \\
\text { Chromium } \\
\text { Magnesium } \\
\text { Nickel } \\
\text { Nitrate } \\
\text { Sodium } \\
\text { Uranium } \\
\text { Zinc } \\
\text { Ammonia } \\
\text { l-Butanol } \\
\text { Alpha Activity (pCi/L) } \\
\text { Beta Activity (pCi/L) } \\
\text { Conductivity ( } \mathrm{pS}) \\
\text { pH (dimensionless) } \\
\left.\text { Temperature ( }{ }^{\circ} \mathrm{C}\right) \\
\text { TOC }\end{array}$ & $\begin{array}{l}4 \\
4 \\
4 \\
1 \\
4 \\
4 \\
4 \\
4 \\
4 \\
4 \\
1 \\
4 \\
4 \\
4 \\
4 \\
4 \\
4\end{array}$ & $\begin{array}{l}6.80 E+01 \\
1.17 E+03 \\
1.06 E+01 \\
2.10 E+01 \\
1.02 E+01 \\
5.50 E+02 \\
2.79 E+02 \\
3.91 E-01 \\
3.50 E+01 \\
3.66 E+05 \\
1.20 E+01 \\
3.01 E+01 \\
3.99 E+04 \\
1.79 E+02 \\
9.35 E+00 \\
3.24 E+01 \\
2.16 E+03\end{array}$ \\
\hline
\end{tabular}

PUREX = Plutonium-Uranium Extraction (Facility) $T O C=$ Total Organic Hydrocarbon

$a_{N}$ is the number of samples in which the analyte was detected. The average concentrations do not reflect less-than values. It is the sum of the detected values divided by $N$. stated.

bunits are parts per bilition uniess otherwise 


\section{DOE/RL-90-41}

Table 4-9 Analyses For PUREX Ammonia Scrubber Feed Stored in Double-shell Tanks.

\begin{tabular}{|c|c|}
\hline Analyte & Average Concentration \\
\hline $\begin{array}{l}\text { Sodium nitrite } \\
\text { Ammonium } \\
\text { Fluoride } \\
\text { Hydroxide ion } \\
\text { pH } \\
\text { Total alpha }\end{array}$ & $\begin{array}{l}0.04 \mathrm{M} \\
0.09 \frac{\mathrm{M}}{\mathrm{M}} \\
2.6 \times 10^{-4} \\
0.02 \mathrm{M} \\
>12.5 \\
0.11 \mu \mathrm{Ci} / 1\end{array}$ \\
\hline
\end{tabular}


Table 4-10. Analytes Reported in the PUREX Process Condensate.

\begin{tabular}{|c|c|c|}
\hline Constituent & $N^{2}$ & $\begin{array}{l}\text { Average } \\
\text { concentration } \\
\text { (ppb) }\end{array}$ \\
\hline $\begin{array}{l}\text { Boron } \\
\text { Calcium } \\
\text { Cyanide } \\
\text { Fluoride } \\
\text { Mercury } \\
\text { Nitrate } \\
\text { Nitrite } \\
\text { Potassium } \\
\text { Silicon } \\
\text { Sodium } \\
\text { Acetone } \\
\text { Ammonia } \\
\text { 1-Butanol } \\
\text { 2-Butanone } \\
\text { Butylated hydroxy }\end{array}$ & $\begin{array}{l}5 \\
5 \\
5 \\
5 \\
5 \\
5 \\
5 \\
5 \\
5 \\
5 \\
4 \\
5 \\
3 \\
4\end{array}$ & $\begin{array}{l}1.64 E+01 \\
5.02 E+01 \\
3.57 E+01 \\
8.60 E+02 \\
9.66 E-01 \\
5.56 E+04 \\
4.93 E+04 \\
5.08 E+02 \\
2.19 E+02 \\
1.29 E+04 \\
5.75 E+01 \\
5.32 E+01 \\
1.90 E+01 \\
2.85 E+01\end{array}$ \\
\hline $\begin{array}{l}\text { toluene } \\
\text { Dibutylphosphate } \\
\text { Dodecane } \\
\text { Tetradecane } \\
\text { Tetrahydrofuran } \\
\text { Tributylphosphate } \\
\text { Tridecane } \\
\text { Undecane } \\
\text { Unknown aliphatic HC } \\
\text { Unknown ester } \\
\text { Unknown ester } \\
\text { Unknown hydrocarbon } \\
\text { Alpha Activity (pC.i/L) } \\
\text { Beta Activity (pCi/L) } \\
\text { Conductivity ( } \mathrm{AS}) \\
\text { Ignitability (०F) } \\
\text { pH (dimensionless) } \\
\text { Temperature (०C) } \\
\text { TOC } \\
\text { Tox (as Cl) }\end{array}$ & $\begin{array}{l}1 \\
4 \\
7 \\
8 \\
4 \\
8 \\
8 \\
1 \\
2 \\
4 \\
3 \\
2 \\
5 \\
5 \\
4 \\
5 \\
4 \\
3 \\
5 \\
5\end{array}$ & $\begin{array}{l}1.00 E+02 \\
1.74 E+04 \\
9.14 E+03 \\
2.10 E+04 \\
7.45 E+01 \\
7.78 E+04 \\
3.28 E+04 \\
1.20 E+02 \\
1.19 E+03 \\
5.24 E+02 \\
3.07 E+01 \\
1.55 E+04 \\
2.25 E+01 \\
7.89 E+00 \\
5.08 E+02 \\
2.08 E+02 \\
3.04 E+00 \\
4.66 E+01 \\
1.06 E+05 \\
4.80 E+01\end{array}$ \\
\hline \multicolumn{3}{|c|}{$\begin{aligned} \text { PUREX } & =\text { Plutonium-Uranium Extraction (Facility } \\
\text { TOC } & =\text { Total Organic Hydrocarbon } \\
\text { TOX } & =\text { Total Organic Halide }\end{aligned}$} \\
\hline
\end{tabular}




$$
\text { D0E/RL-90-41 }
$$

Table 4-11. Analyses of Hexone Waste.

\begin{tabular}{|c|c|c|c|c|}
\hline \multirow{3}{*}{ Compound } & \multicolumn{4}{|c|}{ Concentration, Weight Percent } \\
\hline & \multirow{2}{*}{ Tank 276-S-141 } & \multicolumn{3}{|c|}{ Tank 276-S-142 } \\
\hline & & Organic Phase & Aqueous & S Phase \\
\hline Hexone & 99.0 & 65.2 & & 1.0 \\
\hline $\begin{array}{l}N \text {-alkanes } \\
\left(\mathrm{nC}_{10}-\mathrm{nC}_{15}\right)\end{array}$ & ND & 14.2 & & ND \\
\hline N-tributyl phosphate & ND & 8.4 & & ND \\
\hline Water & 1.0 & 1.0 & & 99.0 \\
\hline $\begin{array}{l}\text { Mono- and di-butyl } \\
\text { phosphates, and } \\
\text { n-alkanes out of the } \\
c_{10}-C_{15} \text { range }\end{array}$ & ND & 12.2 & & ND \\
\hline Total & 100.0 & 100.0 & & 100.0 \\
\hline
\end{tabular}

$N D=$ not detected 
DOE/RL-90-41

Table 4-12. Routine Wastes Discharged to 183-H Solar Basins.

\begin{tabular}{lr}
\hline Constituent & \multicolumn{1}{c}{ Amount } \\
\hline Uranium & $1,988 \mathrm{~kg}$ \\
Chromium & $744 \mathrm{~kg}$ \\
Manganese & $1,411 \mathrm{~kg}$ \\
Copper & $197,948 \mathrm{~kg}$ \\
Nitrate ion & $1,371,291 \mathrm{~kg}$ \\
Sulfate ion & $341,646 \mathrm{~kg}$ \\
Ammonium ion & $1,760 \mathrm{~kg}$ \\
Fluoride ion & $88,360 \mathrm{~kg}$ \\
Average $\mathrm{pH}$ & 9.8 \\
\hline (Total volume $=9,623 \mathrm{~m}^{3}$ )
\end{tabular}


Table 4-13. Listed Wastes Discharged into the 183-H Solar Basins.

\begin{tabular}{|c|c|c|c|c|}
\hline \multirow[b]{2}{*}{ Date } & \multirow{2}{*}{$\begin{array}{l}\text { Material } \\
\text { Description }\end{array}$} & \multicolumn{2}{|c|}{ Quantity } & \multirow{2}{*}{$\begin{array}{l}\text { Dangerous } \\
\text { waste number }\end{array}$} \\
\hline & & liter & $\mathrm{kg}$ & \\
\hline $1 / 15 / 76$ & Unused formic acid & -- & 0.9 & U123 \\
\hline $1 / 15 / 76$ & Unused cyanide solutions & -- & 7.6 & P030 \\
\hline $6 / 29 / 76$ & $\begin{array}{l}\text { Unused saturated vanadium } \\
\text { pentoxide aqueous solution }\end{array}$ & 1.0 & -- & P120 \\
\hline $3 / 7 / 77$ & $\begin{array}{l}\text { Unused chemicals: } \\
\text { cuprous cyanide } \\
\text { sodium cyanide }\end{array}$ & $\begin{array}{l}-- \\
--\end{array}$ & $\begin{array}{l}0.45 \\
0.45\end{array}$ & $\begin{array}{l}\text { P029 } \\
\text { P106 }\end{array}$ \\
\hline $3 / 9 / 77$ & Unused potassium cyaride & -- & 0.23 & P098 \\
\hline
\end{tabular}




\section{DOE/RL-90-41}

Table 4-14. 183-H Basin Number 1 Solids Samples: Constituents Greater than One Percent.

\begin{tabular}{lccccc}
\hline & \multicolumn{2}{c}{$\begin{array}{c}\text { "Inner" basin } \\
\text { sludge content (\%) }\end{array}$} & \multicolumn{2}{c}{ "Outer" basin sludge content (\%) } \\
\cline { 5 - 6 } Constituent & Average & Range & & Sample number 0-0 & Sample number 0-9 \\
\hline & & & & & \\
Sodium & 20.0 & $17.7-23.5$ & 20.5 & 22.9 \\
Copper & 11.9 & $10.0-11.2$ & 5.4 & 1.8 \\
Zirconium & 3.2 & $1.9-3.9$ & 1.6 & 6.7 \\
Fluoride ion & 6.0 & $5.4-6.4$ & 7.1 & 1.6 \\
Nitrate ion & 8.0 & $6.1-10.4$ & 1.4 & 32.7 \\
Sulfate ion & 20.2 & $17.7-23.5$ & 35.5 & 23.1 \\
Water (dried) & 22.2 & $18.7-24.5$ & 22.8 & 0.6 \\
Silicon & $<1$ & $<1$ & 2.8 & \\
\hline
\end{tabular}


Table 4-15. 183-H Bas in Number 2 Siudge Samples:

Sol id Constituents Greater than One Percent.

\begin{tabular}{lcc}
\hline & $\begin{array}{c}\text { Average } \\
\text { Constituent }\end{array}$ & Range (\%) \\
\hline Copper & 13.0 & $9.9-15.4$ \\
Sodium & 9.7 & $4.2-15.9$ \\
Silicon & 2.4 & $0.06-9.3$ \\
Zirconium & 3.2 & $2.8-3.5$ \\
Fluoride ion & 1.1 & $0.57-1.81$ \\
Nitrate ion & 13.5 & $8.2-17.5$ \\
Sulfate ion & 3.8 & $0.65-15.2$ \\
Moisture & 52.7 & $45.7-57.7$ \\
\hline
\end{tabular}


Table 4-16. 183-H Basin Number 3 and 4 Sludge Samples: Major Inorganic Constituents.

\begin{tabular}{|c|c|c|c|c|c|}
\hline \multirow{3}{*}{$\begin{array}{l}\text { Constituent } \\
\text { Copper } \\
\text { Sodium } \\
\text { Zirconium } \\
\text { Fluoride ion } \\
\text { Nitrate ion } \\
\text { Sulfate ion } \\
\text { Moisture }\end{array}$} & \multicolumn{2}{|c|}{$\begin{array}{c}\text { Concentration in Basin Number } 4 \\
\text { sludge samples (\%) }\end{array}$} & \multicolumn{3}{|c|}{$\begin{array}{c}\text { Concentration in Bas in Number } \\
\text { sludge samples }(\%)\end{array}$} \\
\hline & \multirow{2}{*}{$\begin{array}{c}\text { Average } \\
10.3 \\
24.0 \\
4.4 \\
1.1 \\
22.0 \\
1.9 \\
46.0\end{array}$} & Range & \multirow{2}{*}{$\begin{array}{l}\text { Average } \\
11.2 \\
23.0 \\
8.7 \\
1.3 \\
26.0 \\
3.7 \\
42.0\end{array}$} & \multicolumn{2}{|c|}{ Range } \\
\hline & & $\begin{aligned} 9.7 & -12.0 \\
23.0 & -26 \\
0.34 & -13.0 \\
0.98 & -1.2 \\
20.0 & -24.0 \\
1.3 & -3.9 \\
43.0 & -51.0\end{aligned}$ & & $\begin{array}{c}8.8 \\
20.0 \\
2.2 \\
0.98 \\
17.0 \\
1.9 \\
35.0\end{array}$ & $\begin{array}{l}-14.0 \\
-30.0 \\
-22.0 \\
-1.5 \\
-29.0 \\
-5.3 \\
-51.0\end{array}$ \\
\hline \multirow[b]{2}{*}{ Constituent } & \multicolumn{2}{|c|}{$\begin{array}{l}\text { Concentration in Basin Number } 4 \\
\text { crystalline samples (\%) }\end{array}$} & \multicolumn{3}{|c|}{$\begin{array}{c}\text { Concentration in Basin Number } \\
\text { crystalline samples (\%) }\end{array}$} \\
\hline & Average & Range & Average & & ange \\
\hline $\begin{array}{l}\text { Sodium } \\
\text { Sulfate ion } \\
\text { Fluoride ion } \\
\text { Nitrate ion } \\
\text { Moisture }\end{array}$ & $\begin{array}{r}38.0 \\
13.0 \\
2.2 \\
46.6 \\
6.6\end{array}$ & $\begin{array}{cc}30.0 & -50.0 \\
1.5 & -31.0 \\
0.28 & -5.8 \\
7.1 & -71.0 \\
1.1 & -25.0\end{array}$ & $\begin{array}{r}42.0 \\
20 \\
3.6 \\
<1.0 \\
1.1\end{array}$ & $\begin{array}{r}35.0 \\
16.0 \\
2.9 \\
<1 \\
0.55\end{array}$ & $\begin{array}{l}-55.0 \\
-26.0 \\
-4.9 \\
.0 \\
-1.8\end{array}$ \\
\hline
\end{tabular}




\section{DOE/RL-90-41}

Table 4-17. 183-..H Basin Number 2 Liquid Samples: Major Inorganic Constituents.

\begin{tabular}{lcc}
\hline Constituent & Average Concentration (mg/L) & Range (mg/L) \\
\hline Sodium & 140,000 & $120,000-160,000$ \\
Nitrate ion & 380,000 & $310,000-430,000$ \\
Moisture & $(57 \%)$ & $(57-58 \%)$ \\
\hline
\end{tabular}


Table 4-18. 183-H Basin Number 2 Liquid

Samples: Trace Inorganic Constituents.

\begin{tabular}{lcrl}
\hline Constituent & Average Concentration (mg/L) & Range $(\mathrm{mg} / \mathrm{L})$ \\
\hline Aluminum & 36 & $30-$ & 44 \\
Barium & $63 \mathrm{a}$ & $<30-97$ \\
Calcium & $9 \mathrm{a}$ & $<5-$ & 13 \\
Chlorine ion & 290 & $260-$ & 320 \\
Chromium & 20 & $16-$ & 23 \\
Cobalt & 0.6 & $<0.4-$ & 0.77 \\
Copper & 410 & $120-$ & 940 \\
Fluorine ion & 1,00 & $1,400-$ & 1,600 \\
Iron & 7 & 2.8 & 14 \\
Manganese & $7 \mathrm{a}$ & $<4$ & 13 \\
Molybdenum & $1 \mathrm{~b}$ & $<1$ & $<2$ \\
Nickel & 9 & 8.3 & 10 \\
Nitrite ion & 890 & 790 & 1,020 \\
Potassium & 720 & 670 & 820 \\
Silver & 1.8 & 1.1 & 2.8 \\
Strontium & $0.6 \mathrm{c}$ & $<0.5$ & 0.81 \\
Tin & 15 & 10 & 25 \\
Sulfate & 8,000 & 7,800 & 8,300 \\
Zinc & 2.8 & 1.0 & 5.4 \\
Zirconium & 780 & 320 & 1,500 \\
\hline
\end{tabular}

aConstituent less than detection limit in one sample. bonstituent less than detection limit in four samples. ${ }^{c}$ Constituent less than detection limit in three samples. 
Table 4-19. PUREX Tunnels 1 and 2 Waste (Lead and Silver) Waste Generation.

\begin{tabular}{lccc}
\hline & \multicolumn{2}{c}{ Amount } & \\
\cline { 2 - 3 } Date & $113 \mathrm{~kg}$ & Silver & Tunne1 \\
\hline $6 / 60$ & $113 \mathrm{~kg}$ & --- & 1 \\
$12 / 60$ & --- & $625 \mathrm{~kg}$ & 1 \\
$12 / 71$ & $2540 \mathrm{~kg}$ & --- & 2 \\
$11 / 87$ & $230 \mathrm{~kg}$ & $114 \mathrm{~kg}$ & 2 \\
$5 / 88$ & $2996 \mathrm{~kg}$ & $739 \mathrm{~kg}$ & 2 \\
Total & $\left(0.26 \mathrm{~m}^{3}\right)$ & $\left(0.17 \mathrm{~m}^{3}\right)$ & \\
\hline
\end{tabular}


Tabie 4-20 Projected Generation of Central Waste Complex Stored Low-level and Transuranic Waste.

\begin{tabular}{lc}
\hline Year & $\begin{array}{c}\text { Total } \\
\text { (cubic meters) }\end{array}$ \\
\hline 1990 & 1314 \\
1991 & 1127 \\
1992 & 467 \\
1993 & 535 \\
1994 & 323 \\
1995 & 3144 \\
1996 & 3144 \\
1997 & 3144 \\
1998 & 3144 \\
1999 & 4533 \\
2000 & 4533 \\
2001 & 4533 \\
2002 & 4533 \\
2003 & 3116 \\
2004 & 3088 \\
2005 & 3031 \\
2006 & 3031 \\
2007 & 2720 \\
2008 & 2691 \\
2009 & 2691 \\
2010 & 2408 \\
\hline
\end{tabular}


DOE/RL-90-41

Table 4-21. Quantities and Designation of Low-Level Waste Currently in Storage at the Central Waste Complex.

\begin{tabular}{|c|c|c|c|}
\hline $\begin{array}{l}\text { Waste } \\
\text { Code }\end{array}$ & Classification & $\begin{array}{l}\text { Wastes with Only } \\
\text { a Single Code } \\
\text { (cubic meters) }\end{array}$ & $\begin{array}{l}\text { Wastes Exhibiting } \\
\text { Multiple Codes } \\
\text { (cubic meters) }\end{array}$ \\
\hline \multirow{31}{*}{$\begin{array}{l}\text { D001 } \\
\text { D002 } \\
\text { D003 } \\
\text { D004 } \\
\text { D005 } \\
\text { D006 } \\
\text { D007 } \\
\text { D008 } \\
\text { D009 } \\
\text { D010 } \\
\text { D011 } \\
\text { D012 } \\
\text { F001 } \\
\text { F002 } \\
\text { F003 } \\
\text { F005 } \\
\text { WCO1 } \\
\text { WC02 } \\
\text { WP01 } \\
\text { WP02 } \\
\text { WT01 } \\
\text { WT02 } \\
\text { P029 } \\
\text { P030 } \\
\text { P098 } \\
\text { P106 } \\
\text { P120 } \\
\text { U002 } \\
\text { U080 } \\
\text { U123 } \\
\text { U161 }\end{array}$} & Ignitable & 0.15 & 1011. \\
\hline & Corrosive & 0.63 & 35. \\
\hline & Reactive & --- & 0.67 \\
\hline & TCLP-AS & - - & 4. \\
\hline & TCLP-Ba & --- & 51. \\
\hline & & 0.08 & 57. \\
\hline & $\begin{array}{l}\text { TCLP-Cr } \\
\text { TCLP-Pb }\end{array}$ & $-\overline{1.30}$ & $\begin{array}{l}965.9 \\
191.7\end{array}$ \\
\hline & TCLP-Hg & $\cdots$ & 25.6 \\
\hline & TCLP-Se & -- & 41. \\
\hline & TCLP-Ag & --- & 1. \\
\hline & TCLP-Endrin & -- & 10.38 \\
\hline & Spent halogenated solvents & 62. & 101 \\
\hline & Spent halogenated solvents & --- & $-\cdots$ \\
\hline & Spent non-halogenated solvents & --- & -- \\
\hline & Spent non-halogenated solvents & --- & --- \\
\hline & Carcinogenic dangerous waste & 19. & 36. \\
\hline & Carcinogenic dangerous waste & 31. & 40. \\
\hline & Persistent dangerous waste & $-\cdots$ & 38. \\
\hline & Persistent dangerous waste & 1.7 & 64.45 \\
\hline & Toxic dangerous waste & 2.18 & 540. \\
\hline & Toxic dangerous waste & 17.9 & 1027. \\
\hline & Copper cyanide & -- & 940. \\
\hline & Cyanides & -- & 940. \\
\hline & Potassium cyanide & -- & 940. \\
\hline & Sodium cyanide & $-\cdots$ & 940. \\
\hline & Vanadium pentoxide & --- & 940. \\
\hline & Acetone & 0.21 & -- \\
\hline & Dichloromethane & $-\cdots$ & 1.05 \\
\hline & Formic acid & --- & 940. \\
\hline & Methyl i sobutylketone & -- & 0.42 \\
\hline & PCBs & 38. & $\frac{49 .}{1092}$ \\
\hline & Total & 174. & $1242 .^{\mathrm{a}}$ \\
\hline
\end{tabular}

PCBS = Polychlorinated biphenyls

TCLP = Toxic Characteristic Leach Procedure

aIf a container held multiple hazardous constituents, the volume of the container was assigned to each constituent; therefore, the volumes listed in this column cannot be summed to obtain total volume. 
Table 4-22. Quantities and Designation of Transuranic Waste Currently in Storage at the Central Waste Complex.

\begin{tabular}{|c|c|c|c|}
\hline $\begin{array}{l}\text { Waste } \\
\text { Code }\end{array}$ & Classification & $\begin{array}{l}\text { Wastes with Only } \\
\text { a Single Code } \\
\text { (cubic meters) }\end{array}$ & $\begin{array}{l}\text { Wastes Exhibiting } \\
\text { Multiple Codes } \\
\text { (cubic meters) }\end{array}$ \\
\hline D001 & Ignitable & -- & 2.38 \\
\hline 0002 & Corrosive & --- & -- \\
\hline $\begin{array}{l}D 003 \\
0004\end{array}$ & Reactive & --- & --- \\
\hline $\begin{array}{l}D 004 \\
D 005\end{array}$ & $\begin{array}{l}\text { TCLP-As } \\
\text { TCLP-Ba }\end{array}$ & -- & $\begin{array}{l}-\overline{-} \\
--\overline{-}\end{array}$ \\
\hline D006 & TCLP-Cd & -- & 81. \\
\hline $\begin{array}{l}D 007 \\
D 008\end{array}$ & $\begin{array}{l}\text { TCLP-Cr } \\
\text { TCLP-Pb }\end{array}$ & 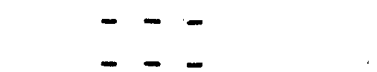 & 0.2 \\
\hline D009 & TCLP-Hg & - - & 81. \\
\hline D010 & $\begin{array}{l}\text { TCLP-Se } \\
\text { TCIP-Aa }\end{array}$ & -- & $-\cdots$ \\
\hline $\begin{array}{l}\text { D011 } \\
\text { F001 }\end{array}$ & Spent halogenated solvents & 8 & $-\overline{\bar{j}}$ \\
\hline F002 & Spent halogenated solvents & --- & $\ldots .3$ \\
\hline F003 & Spent nonhalogenated solvents & -- & -- \\
\hline F005 & Spent nonhalogenated solvents & --- & -- \\
\hline WCOl & Carcinogenic dangerous waste & $-\cdots$ & 31. \\
\hline WCO2 & Carcinogenic dangerous waste & --- & 70. \\
\hline WPOI & Persistent dangerous waste & -- & -- \\
\hline WTO1 & Toxic dangerous waste & --- & 84. \\
\hline $\begin{array}{l}\text { WTO2 } \\
---\end{array}$ & $\begin{array}{l}\text { Toxic dangerous waste } \\
\text { PCBs }\end{array}$ & $\begin{array}{l}1.69 \\
5.04 \\
\end{array}$ & $\begin{array}{r}9 . \\
73 . \\
\end{array}$ \\
\hline & Total & 18. & $93 .{ }^{2}$ \\
\hline
\end{tabular}

PCBs = Polychlorinated biphenyls

TCLP = Toxic Characteristic Leach Procedure

a If a container held multiple hazardous constituents, the volume of the container was assigned to each constituent; therefore, the volumes listed in this column cannot be summed to obtain xtotal volume. 
Table 4-23. Quantities and Designation of Low-Level Waste Currently in Storage at the Retrievable Storage Units.

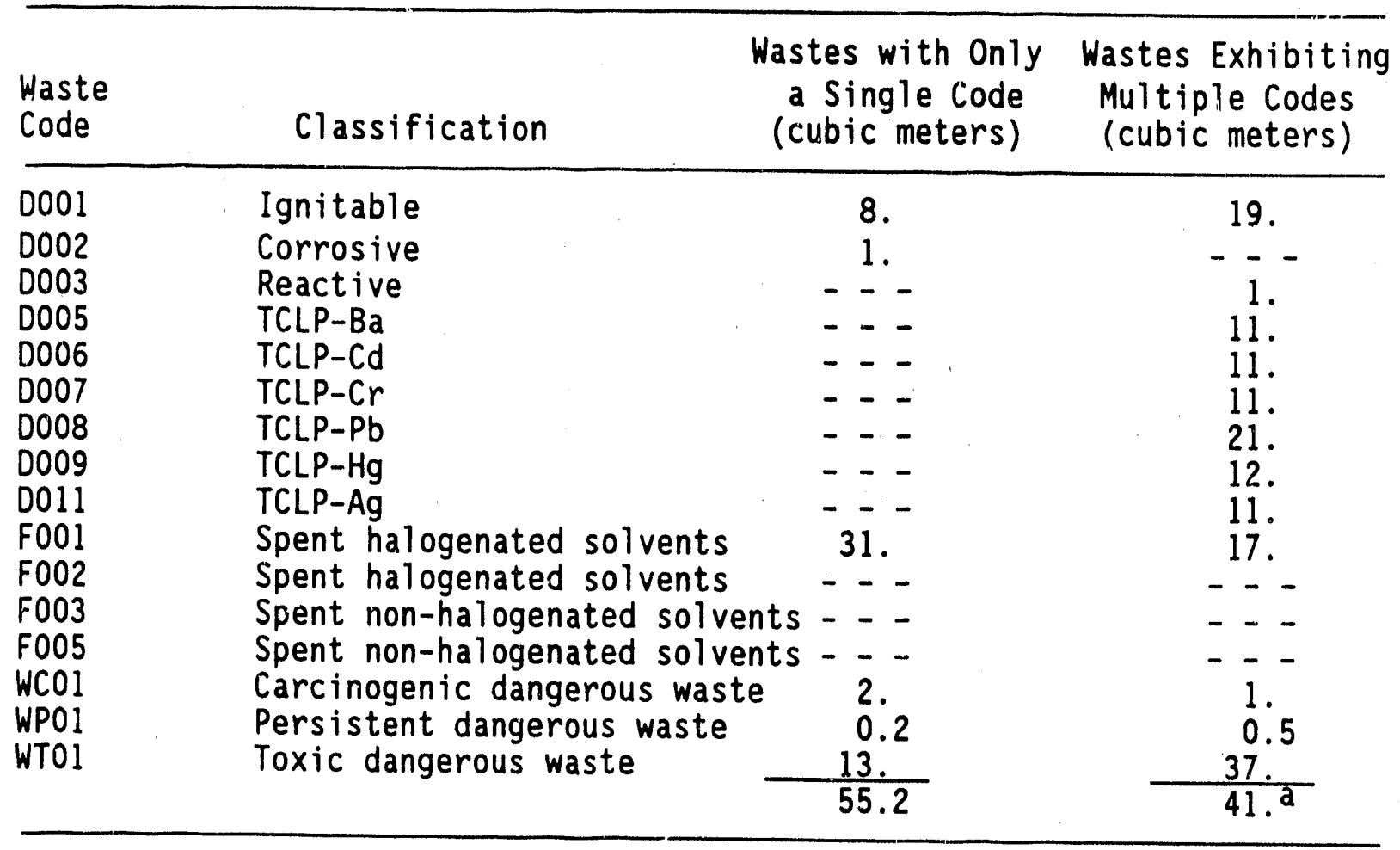

TCLP = Toxic Characteristic Leach Procedure

aff a container held multiple hazardous constituents, the volume of the container was assigned to each constituent; therefore, the volumes listed in this column cannot be summed to obtain total volume. 
Table 4-24. Quantities and Designation of Transuranic Waste Currently in Storage at the Retrievable Storage Units.

\begin{tabular}{|c|c|c|c|}
\hline $\begin{array}{l}\text { Waste } \\
\text { Code }\end{array}$ & Classification & $\begin{array}{l}\text { stes with Only } \\
\text { a Single Code } \\
\text { cubic meters) }\end{array}$ & $\begin{array}{l}\text { Wastes Exhibiting } \\
\text { Multiple Codes } \\
\text { (cubic meters) }\end{array}$ \\
\hline $\begin{array}{l}\text { DO01 } \\
\text { DO02 } \\
\text { DO03 } \\
\text { DO06 } \\
\text { DO08 } \\
\text { D009 } \\
\text { FO01 } \\
\text { FO02 } \\
\text { FO03 } \\
\text { FO05 } \\
\text { WCO1 } \\
\text { WCO2 } \\
\text { WTO1 }\end{array}$ & $\begin{array}{l}\text { Ignitable } \\
\text { Corrosive } \\
\text { Reactive } \\
\text { TCLP-Cd } \\
\text { TCLP-Pb } \\
\text { TCLP-Hg } \\
\text { Spent halogenated solvents } \\
\text { Spent halogenated solvents } \\
\text { Spent non-halogenated solvents } \\
\text { Spent non-halogenated solvents } \\
\text { Carcinogenic dangerous waste } \\
\text { Carcinogenic dangerous waste } \\
\text { Toxic dangerous waste }\end{array}$ & $\begin{array}{c}3 . \\
2 . \\
0.2 \\
--- \\
103 . \\
0.2 \\
51 . \\
--- \\
s--- \\
3-- \\
--- \\
162.4\end{array}$ & $\begin{array}{l}0.5 \\
0.5 \\
--- \\
8 . \\
5 . \\
7 . \\
0.3 \\
--- \\
--- \\
--\overline{-} \\
0.2 \\
70 . \\
12 . \\
72.2\end{array}$ \\
\hline
\end{tabular}

TCLP = Toxic Characteristic Leach Proced're

aIf a container held multiple hazardous constituents, the volume of the container was assigned to each constituent; therefore, the volumes listed in this column cannot be summed to obtain total volume. 


$$
\text { DOE/RL-90-41 }
$$

Table 4-25. Quantities and Designation of TRUSAF Stored Waste.

\begin{tabular}{lcc}
\hline Category & $\begin{array}{c}\text { Single } \\
\text { Constituent }\end{array}$ & $\begin{array}{c}\text { Multiple } \\
\text { Constituent* }\end{array}$ \\
\hline D002 & 0.63 & 24.99 \\
D005 & --- & 0.42 \\
D006 & --- & 1.05 \\
D007 & --- & 0.42 \\
D008 & 3.99 & 31.92 \\
D009 & --- & 0.63 \\
WC01 & --- & 2.94 \\
WC02 & --- & 0.63 \\
WPO1 & --- & 2.52 \\
WT01 & --- & 9.45 \\
Total & & \\
\hline
\end{tabular}

a If a container held multiple hazardous constituents, the volume of the container was assigned to each constituent; therefore, the volumes listed in this column cannot be summed to obtain total volume. 
Table 4-26. Quantities and Designation of 303-K Facility Stored Waste.

\title{
Waste Description
}

Organic Constituents

Perchloroethylene

Trichloroethylene

1,1,1-trichlorethane

Ethyl acetate

Hydraulic oil

\begin{abstract}
Spent halogenated solvent Spent halogenated solvent Spent halogenated solvent Spent non-halogenated solvent Contaminated with halogenated hydrocarbons
\end{abstract}

\section{Organic Degradation Products}

1,1-dichloroethylene cis-1,2-dichloroethylene trans-1,2-dichoroethylene Vinyl chloride

Spent halogenated solvent Spent halogenated solvent Spent halogenated solvent Solvent

\section{Inorganic Constituents}

Acid $\left(\mathrm{HNO}_{3}, \mathrm{HF}, \mathrm{H}_{2} \mathrm{SO}_{4}\right)$

Arsenic ion

Barium ion

$5 \%$ Beryllium/Zircaloy-2a

Cadmium ion

Chromium ion

Lead

Mercury ion

Silver ion

Quench salt, $\left(\mathrm{KNO}_{3}, \mathrm{NaNO}_{3}\right.$, $\mathrm{NaNO}_{2}$ )

Beta salt ( $\mathrm{KCl}, \mathrm{NaCl})$

Crystals, solution, absorbed on opal clay

Solution, sludge

Solution, sludge

Metal alloy

Solution, sludge

Solution, sludge

Metal

Solution, sludge

Solution, sludge

Solid sal:

Solid salt

Zircaloy-2a

Metal alloy

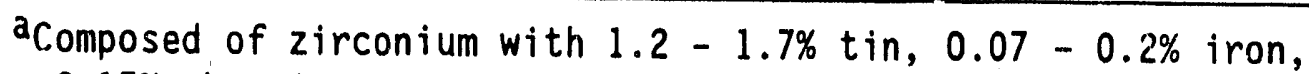
$0.05-0.15 \%$ chromium, $0.03-0.08 \%$ nickel. 


\subsection{REFERENCES}

\subsection{DOCUMENTS}

Adams, M.R., L. Jensen, and W.W. Schulz, Preliminary Assessment of the TRAC Model Predictor of Key Radionuclides, RHO-RE-EV-89-P, September 1986, Rockwell Hanford Operations, Richland, Washingtoll.

DOE, 1987, Final Environmental Impact Statement - Dispnsal of Hanford Defense High-Leve1, Transuranic and Tank Wastes, DOE/EIS-0013, Vo1. 1, U.S. Department of Energy, Washington, D.C.

DOE, 1990, National Report on Prohibited Wastes and Treatment Options, U.S. Department of Energy, Washington, D.C.

DOE/RL, 1989a, Hanford Site Annual Dangerous Waste Report-Mixied Waste, Volume 2, DOE/RL-89-07, U.S. Department of Energy/Richland Operations Office, Richland, Washington.

DOE/RL, 1989b, Hanford Site Dangerous Waste Part A Permit Application, DOE/RL-88-21, Vol 1-3, U.S. Department of Energy/Richland Operations Office, Richland, Washington.

DOE/RL, 1989c, Single-Shell Tank System Closure/Corrective Action Work Plan, DOE/RL-89-16, Draft A, U.S. Department of Energy/Richland Operations Office, Richland, Washington.

DOE/RL, 1990a, 183-H Solar Evaporation Basins Closure/Postclosure Plan, DOE/RL-88-04, Rev. 2, U.S. Department of Energy/Richland Operations Office, Richiand, Washington.

DOE/RL, 1990b, PUREX Storage Tunnels Dangerous Waste Permit Application, DOE/RL-90-24, Rev. 0, DOE/RL Review Draft, U.S. Department of Energy/Richl and Operations Office, Richland, Washington.

DOE/RL, 1990C, 303-K Radioactive Mixed-Waste Storage Facility Closure Plan, DOE/RL-90-004, Rev. 0, U.S. Department of Energy/Richland Operations Office, Richland, Washington.

DOE/RL, 1990d, 304 Concretion Facility RCRA Closure Plan, DOE/RL-90-003, Rev. 0, U.S. Department of Energy-Richland Operations Office, Richland, Washington.

DOE/RL, 1990e, 300 Area Waste Acid Treatment System Closure P7an, DOE/RL-90-11, Rev. 0, U.S. Department of Energy-Rich1 and Operations Office, Richland, Washington.

DOE/RL, 1990f, Hanford Federal Facility Agreement and Consent Order Quarterly Progress Report for the Period Ending June 30, 1990, DOE/RL-90-35, U.S. Department of Energy/Richland Operations Office, Richland, Washington. 
DOE/RL, 1990g, Grout Treatment Facility Dangerous Waste Permit Application, DOE/RL 88-27, Rev. 1, U.S. Department of Energy/Richland Operations Office, Richland, Washington.

Ecology, EPA, and DOE, 1989; Hanford Federal Facility Agreement and Consent Order, Washington State Department of Ecology, U.S. Environmental Protection Agency, U.S. Department of Energy, 01ympia, Washington.

EPA, 1983a, Guidelines and Specifications for Preparing Quality Assurance Program Plans, QAMS-004/80, U.S. Environmental Protection Agency, Washington, D.C.

EPA, 1983b, Interim Guidance and Specifications for Preparing Quality Assurance Project Plans, QAMS-005/80, U.S. Environmental Protection Agency, Hashington, D.C.

EPA, 1986, Test Methods for the Evaluation of Solid Waste: Physical/Chemical Methods, SW-846, 3rd ed., U.S. Environmental Protection Agency, Washington, D.C.

RHO, 1985, Hanford Defense Waste Disposal Alternatives: Engineering Support Data for the Hanford Defense Waste Environmental Impact Statement, RHO-RE-ST-3OP, December 1985, Rockwell Hanford Operations, Richland, Washington.

Weiss, R.L., 1986, TY Tank Farm Waste Characterization Data, RHO-WM-TI-1P, Rockwell Hanford Operations, Richland Washington.

WHC, 1989a, Doub7e-Shell Tank Waste Disposal Integration Plan, WHC-EP-0229, Rev. 1, January 1989, Westinghouse Hanford Company, Richland, Washington.

WHC, 1989b, Wastestream Characterization Report, WHC-EP-0287, Westinghouse Hanford Company, Richland, Washington.

WIC, 1990a, Tank Farm Surveillance and Wastestream Status Summary Report for May 1990, WHC-EP-0182-26, August 1990, Westinghouse Hanford Company, Richland, Washington.

WHC, 1990b, Annual Report of Tank Waste Treatability Studies, WHC-EP-0365, R.A. Karnesky, Westinghouse Hanford Company, Richland, Washington.

WHC, 1990C, Single-Shell Tank Waste Retrieval Study, WHC-EP-0352, UC-721, June 1990, Westinghouse Hanford Company, Richland, Washington.

WHC, 1990d, Functional Requirement Baseline for the Closure of Single-She11 Tanks, WliC-EP-0338, Draft, July 1990, Westinghouse Hanford Company, Richl and, Washington.

WHC, 1990e, Preliminary 242-A Evaporator Process Condensate Stream-Specific Report, WHC-EP-0342, Addendum 15, Draft, April 30, 1990, Westinghouse Hanford Company, Richland, Washington. 
WHC, 1990f, PUREX Plant Ammonia Scrubber Condensate Stream-Specific Report, WHC-EP-0342, Addendum 14, Westinghouse Hanford Company, Richland, Washington.

WHC, 1990g, Westinghouse Hanford Company Solid Waste Management Program Plan, WHC-EP-0363, June 1990, Westinghouse Hanford Company, Richland, Washington.

WHC, 1990h, Engineering Study for Waste Receiving and Processing Facility, Module 2, WHC-SD-W100-ES-001, February 7, 1990, Westinghouse Hanford Company, Richiland, Washington.

WHC, 1990i, Sampling Plan for Retrievably Stored Contact-Handled Transuranic Waste at the Hanford Site, WHC-EP-0226, December 1989, Westinghouse Hanford Company, Richland, Washington.

WHC, 1990j, Stored, Contact-Handled Transuranic Waste Characterization at the Hanford Site, WHC-EP-0223, December 1989, Westinghouse Hanford Company, Richland, Washington.

WHC, 1990k, Hanford Site LDR RMW Stream Data Package, WHC-MR-0224, Westinghouse Hanford Company, Richland, Washington.

WHC, 19901, PUREX Plant Process Condensate Stream-Specific Report, WHC-EP-0342, Addendum 12, Westinghouse Hanford Company, Richland, Washington.

Winters, W.I., et al., Waste Characterization Plan for the Hanford Site Single-Shell Tanks, 1989, WHC-EP-0210, Westinghouse Hanford Company, Richland, Washington.

\subsection{CODE OF FEDERAL REGULATIONS AND FEDERAL REGISTER}

40 CFR 265, Interim Status Standards for Owners and Operators of Hazardous Waste Treatment, Storage, and Disposal Facilities, Title 40, Code of Federal Regulations, Part 265, as amended, U.S. Environmental Protection Agency, Washington, D.C.

40 CFR 268, Land Disposal Restrictions, Title 40 Code of Federal Regulations, Part 268, as amended, U.S. Environmental Protection Agency, Washington, D.C.

55 FR 22520, et seq., Land Disposal Restrictions for Third Third Scheduled Wastes, Final Rule, Title 40, Code of Federal Regulations, Parts 148, $261,262,264,265,268,270,271$, and 302, Federal Register, June 1, 1990, U.S. Environmental Protection Agency, Washington, D.C.

\subsection{FEDERAL AND STATE ACTS}

Atomic Energy Act of 1954, as amended, Public Law 83-703, 66 Stat. 919, 42 USC 2011 et seq. 
National Environmental Policy Act, as amended, Public Law 91-190, 42 USC 4321 et seq.

Resource Conservation and Recovery Act of 1976, as amended, Public Law 94-570, 90 Stat. 2795, 42 USC 6901 et seq.

State of Washington Hazardous Waste Management Act of 1970, as amended, Revised Code of Washington, Chapter 70.105, 01ympia, Washingtor.

\subsection{WASHINGTON ADMINISTRATIVE CODE}

WAC 173-303, Dangerous Waste Regulations, 1989, Washington State Department of Ecology, Olympia, Washington. 

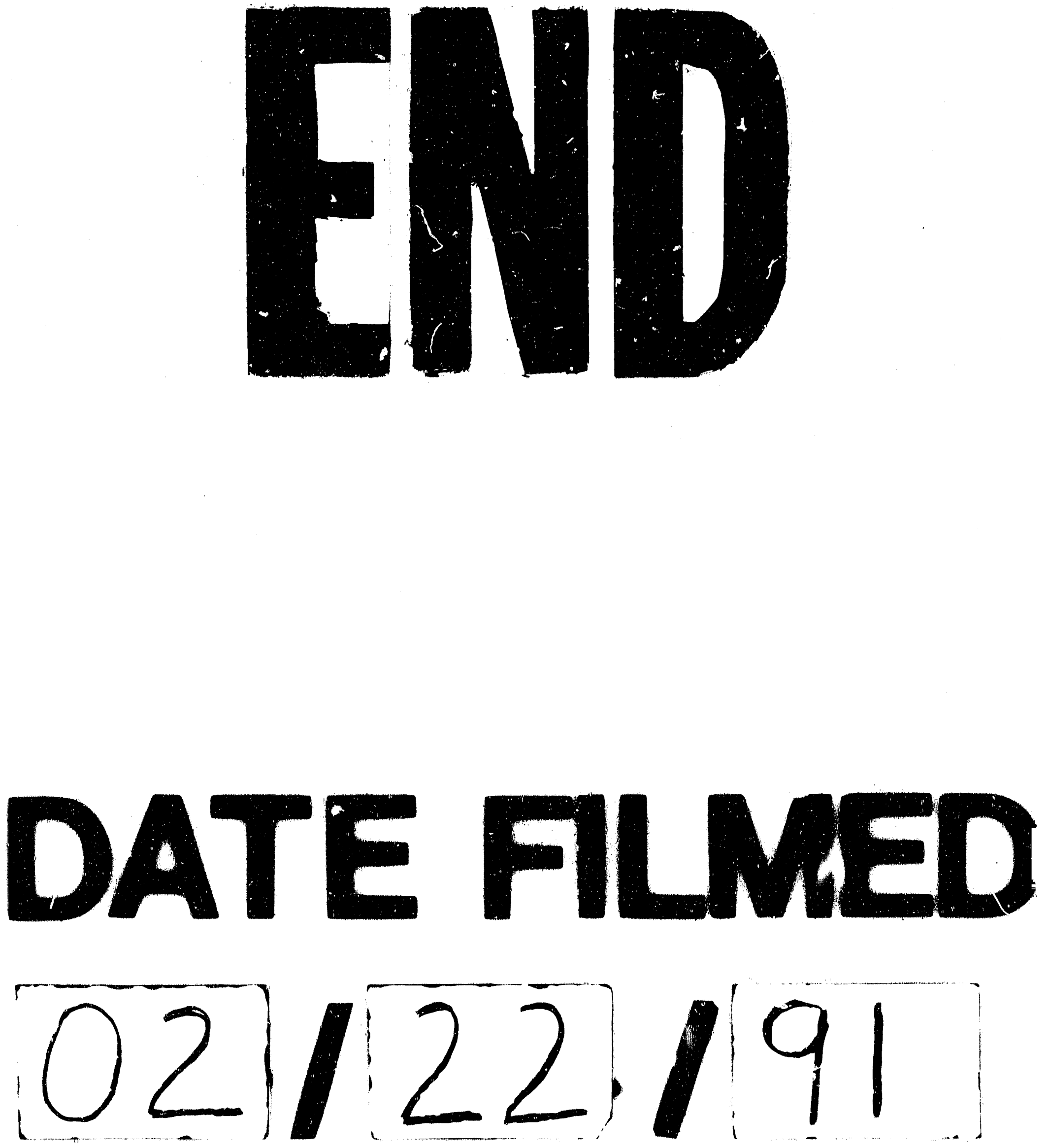

$m^{\prime \prime}$ 
